\title{
The interrelationships between faulting and volcanism in the Okataina Volcanic Centre, New Zealand
}

\section{Hannu Seebeck}

A thesis

Submitted to the Victoria University of Wellington In fulfilment of the requirement for the degree of Masters in Geology 


\begin{abstract}
Continental rifts show close spatial relations between faulting and volcanism, however the interrelations between each process and their roles in the accommodation of regional extension are not well understood. The geometric and kinematic relations between an active silicic caldera complex and active faults in the upper 3-4 km of the crust (i.e. Taupo Rift) are investigated using regional gravity data, digital elevation models, outcrop mapping, seismic reflection lines, focal mechanisms and an historical account of the 1886 AD Tarawera eruption adjacent to, and within, the Okataina Volcanic Centre, New Zealand.
\end{abstract}

The location and geometry of the Okataina Caldera were influenced by preexisting faults. The caldera is elongate north-south, has a maximum subsidence of 3 $\pm 0.5 \mathrm{~km}$ at the rift axis and occupies a $10 \mathrm{~km}$ hard-linked left step in the rift. The principal rift faults (55-75 ${ }^{\circ}$ dip) define the location and geometry of the northwest and southeast margins and locally accommodate piecemeal caldera collapse. Segments of the east and west margins of the caldera margin are near vertical (70-90 dip), trend north-south, and are inferred to be faults formed by the reactivation of a pervasive Mesozoic basement fabric (i.e. bedding, terrane boundaries, and/or faults).

Measured displacements along the Paeroa and Whirinaki Fault zones in, and adjacent to, the Okataina Volcanic Centre took place over time periods ranging from 60 to $220 \mathrm{ka}$ (together with historical accounts of the $1886 \mathrm{AD}$ Tarawera eruption). These indicate that neither dike intrusion nor caldera collapse have a measurable influence on fault displacement rates outside the volcanic complex. Within the volcanic complex, vertical displacement along the Whirinaki Fault zone increases by up to $50 \%$ between the caldera topographic margin and inner collapse boundary. This increase in vertical displacement is predominantly due to the collapse of the caldera $60 \mathrm{ka}$ ago. In the Okataina Volcanic Centre, extension is accommodated by a combination of tectonic faulting, dike intrusion, and gravitational caldera collapse. Gravitational caldera collapse is however, superimposed on regional extension without contributing to it.

Rift-orthogonal extension dominates across the Taupo Rift with a minor $\left(\leq 20^{\circ}\right)$ component of right-lateral slip increasing northwards. The regional principal horizontal extension direction rotates $30^{\circ}$ clockwise south to north along the rift. The modal principal horizontal extension direction for the Okataina Volcanic Centre trends $\sim 145^{\circ}$, approximately normal to northeast striking rift faults and intra-caldera linear vent zones, and oblique to north-south faults. Zones of crustal weakness, brittle deformation, and dilation at the intersections of northeast-southwest dip slip and north-south oblique slip active fault sets are inferred to locally promote the ascent of magma.

Preliminary examination of volcanism outside the Okataina Volcanic Centre suggests that intersecting northeast-southwest and north-south fault sets may also play a role in defining the geometry of calderas and locations of volcanic centres throughout the Taupo Volcanic Zone. Outside these volcanic centres (e.g. Taupo and Okataina) active extension is primarily accommodated by normal faulting which is driven by tectonic processes (e.g. far-field plate motions) and is not attributed to dike intrusion. The Taupo Rift has not yet reached the stage where it is dominated by magma-assisted extension and is primarily a young tectonic rift in an arc environment. 


\section{Acknowledgements}

The design of this study, data acquisition, its interpretation, presentation, and production represent the efforts of the author. Hugh Bibby and Bryan Davy are thanked for providing data and discussions, in particular to Hugh for his knowledge on the TVZ fluid systems and a helpful review. Nick Mortimer and Graham Leonard are thanked for providing unpublished data. Vaughan Stagpoole is thanked for his technical support and review of the gravity interpretations. Discussions with Euan Smith have been much appreciated in the understanding and interpretation of geophysical data sets, while John Begg is thanked for his advice in the art of geologic interpretation.

Many people have contributed directly and indirectly to this thesis through their support and assistance; John and Catherine Ford are kindly thanked for their hospitality, Dr Stephen McNeil (Landcare Research) for TOPSAR data, Rex King and Ed Bright (Kaingaroa Timberlands \& Hancock Forest Management respectively) for land access, Environment Bay of Plenty for the high resolution aerial photographs of the Okataina Region and Dhiresh Hansaraj, Dan Bassett, and Ken Seebeck for their assistance in the field. Gillian Ruthven is thanked for help in tracking things down. I am grateful for the financial support provided by Victoria University of Wellington in the form of an MSc scholarship and to GNS Science for supporting my field expenses.

My main thanks go to Andy Nicol (chief supervisor) and Tim Stern (secondary supervisor). Their foresight and patience has provided a young scientist with an ideal project with which to learn the tools of his trade. Andy's contribution to the thesis has been through a guiding rather than leading role. The major contribution of the chief supervisor was in the discussion of scientific ideas and concepts and as an editor for both words and images. Helping maintain the focus of this thesis has been the greatest achievement of both supervisors in view of such an interesting and diverse scientific landscape. 


\section{TABLE OF CONTENTS}

\section{Page}

Abstract

Acknowledgements

List of Figures

vii

List of Tables

viii

\section{Introduction}

1.1 Introduction 2

1.2 Geological setting of study 5

1.2.1 Plate Boundary 5

1.2.2 Taupo Volcanic Zone 8

$\begin{array}{lll}\text { 1.2.3 Okataina Volcanic Centre } & 10\end{array}$

1.2.4 Taupo Rift 12

$\begin{array}{lll}\text { 1.2.5 North Island basement } & 13\end{array}$

$\begin{array}{lll}1.3 & \text { Thesis organisation and contents } & 15\end{array}$

2. Fault controls on the geometry and location of the Okataina Caldera

$\begin{array}{lll}2.1 & \text { Introduction } & 19\end{array}$

2.2 Methods \& Data 22

2.2.1 Gravity 22

2.2.2 Interpretation uncertainties 25

$\begin{array}{lll}2.2 .3 & \text { Rock properties } & 26\end{array}$

2.2.4 1D Gravity modelling $\quad 29$

2.2.5 21/2D Gravity modelling $\quad 30$

2.2.6 Seismic reflection lines 32

2.2.7 Topographic Analysis 36

2.3 Continuity of faults through the caldera complex 38

2.3.1 Geometry of Okataina Caldera 42

2.4 Origin of Caldera Geometry 44 
2.5 Caldera collapse style 46

2.6 Discussion 48

2.6.1 Relations between faulting and caldera formation 48

2.6.2 Fault displacement and Basement depth 49

2.7 Conclusions 50

3. Impact of dike intrusion and caldera collapse on accumulation of fault displacements in the Okataina Volcanic Centre

3.1 Introduction 52

3.2 Methods \& Data 54

3.2.1 Topographic analysis $\quad 54$

3.2.2 Seismic reflection lines 57

3.2.3 Gravity models 57

3.2.4 Fault displacement uncertainties 58

3.2.5 Cumulative fault zone profiles 62

3.3 Dike and Fault interaction 62

3.3.1 Faulting associated with 1886 AD eruption 63

3.3.2 Paeroa Fault zone displacement rates 65

3.3.3 Dike intrusion and regional extension $\quad 69$

$\begin{array}{lll}3.4 & \text { Caldera collapse and Fault displacements } & 70\end{array}$

3.4.1 Whirinaki Fault zone cumulative displacement rates 71

3.4.2 Taupo Rift along-strike displacements 73

$\begin{array}{lll}3.5 & \text { Conclusions } & 76\end{array}$

4. Relationships between faulting and volcanism in the Okataina Volcanic Centre

$\begin{array}{lll}4.1 & \text { Introduction } & 78\end{array}$

$\begin{array}{lll}4.2 & \text { Methods \& Data } & 79\end{array}$

4.2.1 Principal horizontal extension (PHE) direction 79

4.2.2 Local PHE estimates 82

4.2.3 Regional PHE estimates 83

$\begin{array}{lll}4.3 & \text { Relations between Faulting and Volcanism } & 87\end{array}$

$\begin{array}{lll}\text { 4.3.1 } & \text { Fault Geometries } & 87\end{array}$

$\begin{array}{lll}\text { 4.3.2 } & \text { Principal horizontal extension direction } & 89\end{array}$ 
4.4 Faulting and linear volcanic vent locations 91

4.5 Faulting-volcanism model for the OVC 94

$\begin{array}{lll}4.6 & \text { Discussion } & 95\end{array}$

4.6.1 Magmatic verses fault TVZ extension 95

$\begin{array}{lll}4.7 & \text { Conclusions } & 100\end{array}$

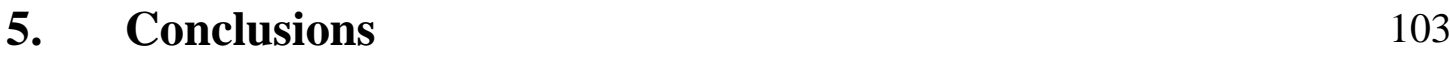

$\begin{array}{ll}\text { References } & 107\end{array}$

6. Appendix I: Gravity 119

7. Appendix II: Topographic analysis 140 


\section{LIST OF FIGURES}

Figure

Page

1.1 Schematic diagram showing extension due to normal faulting and dike intrusion

1.2 Regional tectonic setting of the North Island of New Zealand

1.3 Present volcano-tectonic setting of the North Island of New Zealand

1.4 Simplified volcanic stratigraphy and chapter study areas of the OVC

2.1 Caldera formation models

2.2 Mesozoic basement terranes, bedding strikes, residual gravity, and seismicity of the central North Island

2.3 Residual gravity anomaly map of the Okataina Volcanic Centre

2.4 TVZ Geothermal composite drill-hole stratigraphy and density

$2.5 \quad 1 \mathrm{D}$ gravity models calculated from exponentially decreasing density contrasts with depth

Preliminary interpretation of a magnetotelluric 2D inversion model across the OVC

2.7 Residual gravity profiles across the OVC

2.8 Active fault map of the southwest margin of the Okataina Volcanic Centre

2.9a Rift parallel seismic line A

2.9b Rift perpendicular seismic reflection line B 40

2.9c Rift perpendicular seismic reflection line C $\quad 41$

2.10 Gravity profiles perpendicular to the Taupo Rift 45

2.11 Gravity models of the Okataina Caldera collapse geometry 47

3.1 Schematic end-member relationships between tectonic faults, dike intrusion, and caldera collapse through a volcanic complex

3.2 Example of digital elevation model (DEM) showing measurement of vertical fault displacement

3.3 Paeroa Fault zone adjacent to the south-western margin of the OVC 
3.4 Whirinaki Fault zone adjacent to the western margin of the OVC

3.5 1886 AD Tarawera dike intrusion in relation to the Paeroa Fault zone termination of 1886 AD dike intrusion

3.7 Relations between basement depth, fault style and displacement along the Paeroa Fault zone

3.8 Whirinaki Fault zone displacement rates along-strike towards Okataina Caldera

3.9 Multi-1D basement model derived from residual gravity data

Basement altitude and cumulative vertical separation profiles alongstrike of the Taupo Rift

4.1 Residual gravity map and simplified faults of the central North Island

4.2 Surface expression of volcanism in the central TVZ

4.3 Azimuths for principal horizontal extension (PHE) direction measurement along the Taupo Rift

4.4 Simplified map showing fault geometries and kinematics in Okataina area.

4.5 Structural models for the location of the OVC and its relation to the regional extension direction.

4.6 Spatial relations between TVZ calderas and geothermal activity

\section{LIST OF TABLES}

Table

2.1 TVZ rock density analysis

4.1 Fault slip data from the Taupo Rift

4. 2

Variation in rift crustal thicknesses and faulting for increasing extensional strain 
CHAPTER ONE

INTRODUCTION 


\subsection{Background and Aims}

The rifting of the Earth's crust is a fundamental component of plate tectonics and typically accompanied by spatially coincident volcanism [Bacon, 1985; Ferguson et al., 1994; Ring; 1994; Ruppel, 1995; Hayward \& Ebinger, 1996; Gudmundsson, 1998; Prejean et al., 2002; Zeigler \& Cloetingh, 2004]. At mid-ocean ridges and in volcanic rifts, the generation of new crust during dike intrusion is considered the principal manifestation of extension [e.g. Rubin \& Pollard, 1988; Rubin, 1992; Ebinger \& Casey, 2001; Gudmundsson, 2002; Wright et al., 2006]. Recent studies in the Afar Rift, for example, indicate that dike intrusion at depths of between 2 and $9 \mathrm{~km}$ triggers slip on normal faults at the ground surface and is the primary mode of extension within the crust [Ebinger \& Casey, 2001; Kendall et al., 2005; Wright et al., 2006]. Regional extension accommodated by dike intrusion in Afar has also been observed in Iceland, the Gulf of Aden, and the Mid-Altantic Ridge [Rubin \& Pollard, 1988; Gudmundsson, 2000, Corti et al., 2003 and references therein].

For rifts in continental crust, the relative importance of extension accommodated by volcanism (i.e. dike intrusion) and faulting is frequently a point of debate. The lack of consensus for the relations between faulting and volcanism in continental rifts is partly due to the wide diversity of faulting patterns and types of volcanism in these tectonic settings, which leads to a variety of relations between the two processes [e.g. Mastin \& Pollard, 1988; Rubin \& Pollard, 1988; Ferguson et al., 1994; Ring, 1994; Hayward \& Ebinger, 1996, Gudmundsson, 1998; Acocella et al., 2002; Prejean et al., 2002: Ziegler \& Cleotingh, 2004; Cole et al., 2005]. These relations can be described by two end-member models which are: 1) the faulting extensional model where crustal stretching is primarily accommodated by normal faults that control the location of volcanic intrusion and vents (Fig. 1.1a) [Ferguson et al., 1994; Hayward \& Ebinger, 1996; Prejean et al., 2002; Corti et al., 2003; Zeigler \& Cloetingh, 2004]; 2) the dike intrusion extensional model where the intrusion of fault-parallel dikes accommodate much of the extension at depth in the crust along the rift and controls the location, timing and size of incremental slip of normal faults at the ground surface (Fig. 1.1b) [Mastin \& Pollard, 1988; Rubin \& Pollard, 1988; Ruppel, 1995; Gudmundsson, 1998; Bosworth 2003; Wright et al., 2006].

Although extension in both models is driven by plate motions and may produce comparable patterns of faulting, the role of volcanism in the rifting process is fundamentally different for each model. 

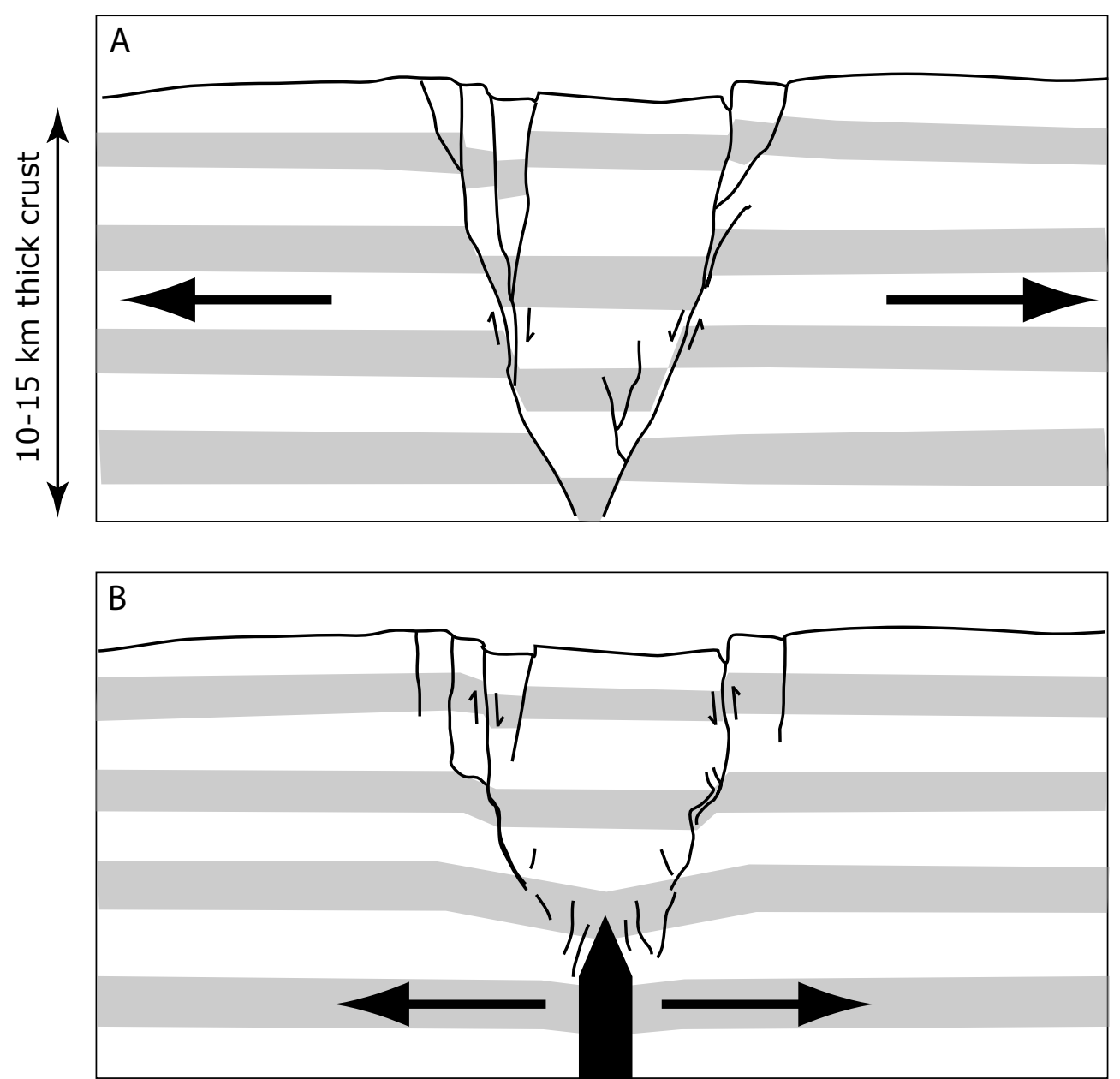

Fig. 1.1 Schematic diagram showing extension due to normal faulting and dike intrusion. (A) Horizontal extension accomodated by displacement on graben forming normal faults to seismogenic depths [e.g. Ruppel, 1995; Hayward \& Ebinger, 1996]. (B) Horizontal extension accommodated by dike intrusion. Dike intrusion events fill the accommodation space created by plate motions and trigger slip on normal faults intersecting or in front of a laterally propagating dike. Normal faults accrue displacement across a symmetrical graben centred on the intrusion, accomodating some of the horizontal extension [e.g. Rubin \& Pollard, 1988; Wright et al., 2006]. 
In the faulting model, the rise of magma to the ground surface is facilitated by faulting which, in the extreme, may trigger volcanism. By contrast, volcanism in the dike intrusion model accommodates extension and triggers faulting at the ground surface. Discriminating between these models therefore has implications for the mechanics of rifting and the hazards associated with earthquakes and volcanism in arc rifts. Thus it is important to determine under which geological conditions each of these models are likely to apply.

The present thesis concentrates on establishing the temporal and spatial relations between the development of the active Taupo Rift and Taupo Volcanic Zone (TVZ) in continental crust of the central North Island of New Zealand. Active volcanism in this zone predominantly occurs within the Okataina and Taupo volcanic centres through which the rift passes. This study concentrates on the southwest margin of the Okataina Volcanic Centre (OVC), the most recently active of the eight rhyolitic caldera complexes in the TVZ [Nairn, 2002]. An extensive array of normal faults can be traced into the OVC using a combination of geological mapping [e.g., Nairn, 1989; this study], seismic reflection profiles [Davy \& Bibby, 2005] and gravity analysis [Stagpoole \& Bibby, 1999; this study]. In combination with published accounts of OVC volcanism [Cole, 1970; Nairn \& Cole, 1981; Nairn, 2002; Leonard et al., 2002; Shane et al., 2005; Nairn et al., 2005], these data permit five key questions to be addressed for the study area. These are: i) Is there evidence for dike intrusion accommodating extension of the crust? ii) Does caldera collapse utilise, and locally increase displacements on existing faults within the OVC? iii) Do faults play a role in localising volcanism? iv) Does the volcanic complex play a role localising faults? v) Do volcanic eruptions trigger fault slip? Providing answers to these questions will present important clues as to what role rift faults play in the formation of volcanism (and vice versa) in the region of study.

To answer these questions the following data sets have been constructed and analysed: (i) fault mapping from aerial photographs, outcrop, seismic reflection lines [Davy \& Bibby, 2005] and gravity data; (ii) fault kinematic analysis from vertical displacement of the land surface measured using a new digital elevation model, published focal mechanisms, stress inversions, and GPS data [Robinson, 1989; Anderson \& Webb, 1998; Beavan \& Haines, 2001; Hurst et al., 2002; Hayes et al., 2004; Beavan et al., 2007; Hurst et al., 2008]; (iii) existing information on the volcanism and faulting [Cole, 1970; Nairn \& Cole, 1981; Beanland et al., 1989; Rowland \& Sibson, 2001; Villamor \& Berryman, 2001; Nairn, 2002; Acocella et al., 2003; Nairn et al., 2005]; and (iv) a historical account of the relations between the 1886 AD Tarawera 
eruption and faulting [Smith, 1886]. These data provide information on the relative locations and geometries of faults, caldera collapse structures, and volcanic domes to depths of up to $4 \mathrm{~km}$. They show how rift faults, which partly inherit basement fabric, influence the location and geometry of calderas and volcanic vents. The data also help constrain fault kinematics and the principal horizontal extension direction in the rift while fault displacements indicate the extent to which fault growth has been influenced by caldera collapse and dike intrusion over the last ca. 500 kyr.

\subsection{Geological setting of study}

This study has been conducted in the active Taupo Volcanic Zone (TVZ) including the Taupo Rift, New Zealand. The following section places the study area in a geological context and provides an introduction to some of the key research that has been conducted on the faulting and volcanism in the central North Island over the last 50 years. This literature review is not intended to be exhaustive but rather to cover the salient points critical to this study.

\subsubsection{Plate Boundary}

The Okataina Volcanic Centre lies within TVZ, the southern continental continuation of oceanic arc volcanism forming in association with subduction of the Pacific Plate beneath the Australian Plate along the Tonga-Kermadec-Hikurangi subduction margin. TVZ volcanism has formed in response to $42-48 \mathrm{~mm} / \mathrm{yr}$ oblique subduction east of New Zealand along the Hikurangi Margin (Fig. 1.2) [Stern, 1987; Walcott, 1987; Cole; 1990; Wilson et al; 1995; Beavan et al., 2002]. Despite the obliquity of the relative plate motion, rifting in the TVZ is approximately orthogonal [e.g. Rowland \& Sibson, 2001; Hurst et al., 2002; Acocella et al., 2003]. Rifting associated with the TVZ-Kermadec arc/back arc volcanic system is accompanied by rhyolitic caldera formation and andesitic stratovolcanoes [Cole, 1990; Wilson et al., 1995; Wright et al., 2006].

Volcanic activity occurred in the Northland arc between $~ 16-23$ Ma [Hayward et

al., 2001], in Taranaki between 14 and 5 Ma [King \& Thrasher, 1996], the Coromandel arc from ca. 12 to 2 Ma [Carter et al., 2003; Briggs et al., 2005] with TVZ volcanism commencing around $2 \mathrm{Ma}$ along the present northeast-southwest trend [Wilson et al., 1995]. Volcanic rocks in the North Island are dominated by arc and backarc chemistry (e.g. andesite, dacite, low silica rhyolite complexes) and appear to have formed in association with subduction of the Pacific Plate [e.g. Cole et al., 2001; Hayward et al; 2001; Price et al., 2005; Mortimer et al., 2007]. 


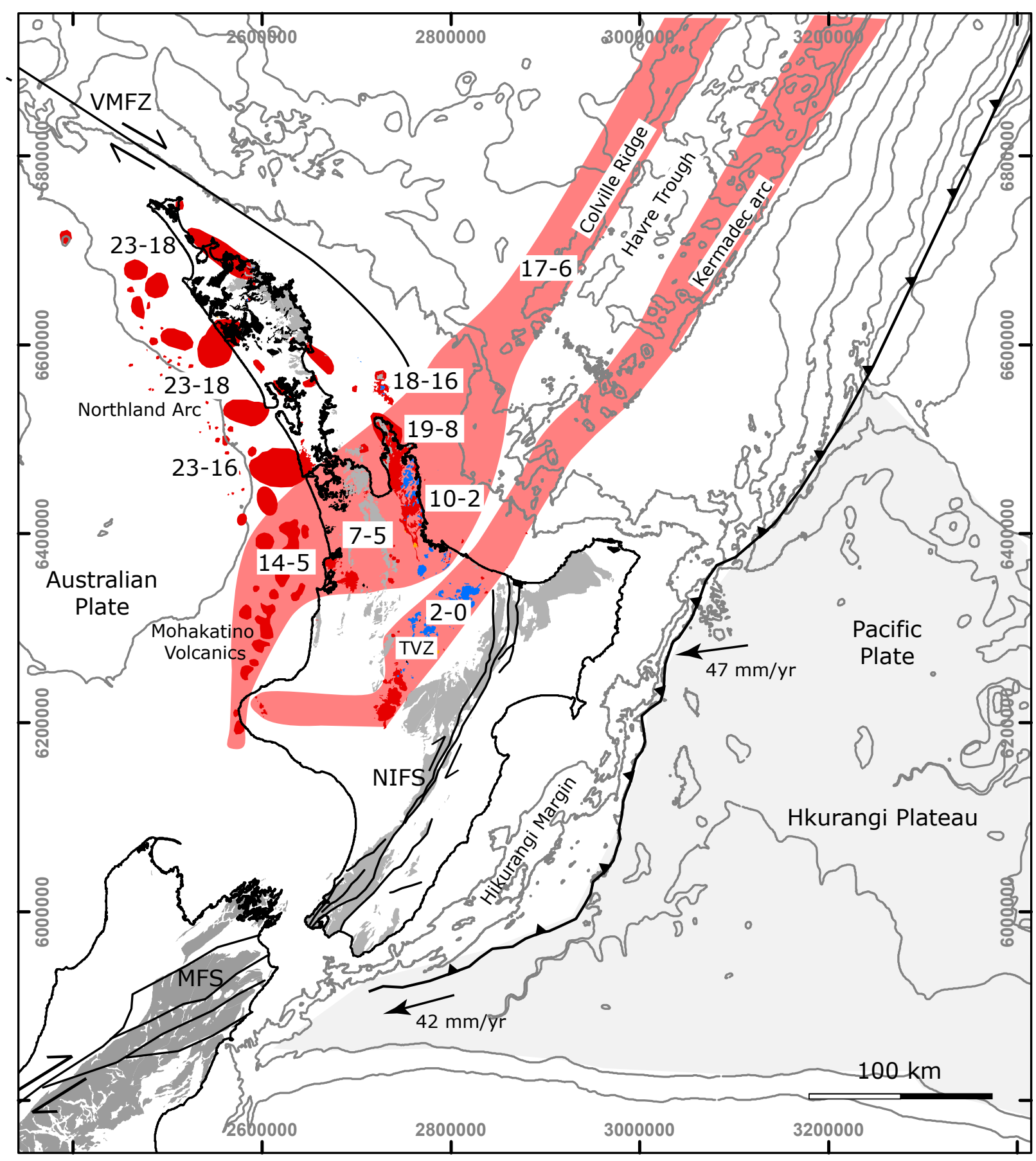

Fig. 1.2. Regional tectonic setting of the North Island of New Zealand. Oblique subduction of the Pacific Plate beneath the Australian Plate has produced continuous volcanism along northnortheast to northeast trending volcanic arc systems since the Mid Miocene (red shading), ages of volcanism in Ma [Adams et al., 1994; Wilson et al; 1995; Hayward et al., 2001; Carter et al., 2003; Briggs et al., 2005; Mortimer et al., 2007]. The change in orientation between the Early Miocene Northland arc and Colville Ridge is inferred to be in response to a rapid roll-back of an east facing subduction zone decoupled from the North Island continental crust by the Vening-Meinesz Fracture Zone (VMFZ) [Ballance, 1976; Walcott, 1987; King, 2000; Mortimer et al., 2007]. Clockwise rotation of the eastern North Island relative to the west at rates of $3-7^{\circ} / \mathrm{Myr}$ have been accommodated by normal faulting and volcanism in the TVZ over the last 2 Myr [Walcott, 1987; Stern, 1987; Villamor \& Berryman, 2001; Wallace et al; 2004; Nicol et al., 2007]. Abbreviations: NIFS, North Island Fault System; MFS, Marlborough Fault System. 
While the TVZ-Kermadec and Mohakatino-Colville arcs trend approximately parallel to the present strike of the subducting plate, the older Early to Mid Miocene Northland arc trends up to $60^{\circ}$ anticlockwise of the plate strike (Fig. 1.2) [e.g. Stern, 1987; Walcott, 1987; King, 2000; Mortimer et al., 2007]. Rapid-switch and fan-shaped opening models have been proposed to account for the change in arc trends through the North Island and the Central Volcanic Region (which contains the TVZ) [Stern, 1987; Walcott, 1987; Wilson et al., 1995; Wallace et al., 2004].

The apparent change in the trend of volcanic arcs is consistent with clockwise rotation of the Hikurangi margin. This rotation of the eastern North Island relative to the west at a rate of $\sim 3-7^{\circ} / \mathrm{Myr}$ [Stern, 1987; Walcott, 1987; Wallace et al., 2004; Nicol et al., 2007] is interpreted to result from slab rollback [Walcott, 1987] and, due to torque exerted on the North Island, by continental collision at the southern end of the Hikurangi margin (Fig. 1.2) [Wallace et al., 2004]. Rapid slab rollback of a single eastfacing Pacific arc-trench system is interpreted to have produced the general eastward younging of volcanic arcs across the North Island and the south Fiji Basin [Ballance, 1976; Mortimer et al., 2007].

TVZ volcanism is approximately spatially coincident with a narrow $(\leq 60 \mathrm{~km}$ wide) zone of observable crustal extension [Cole, 1990; Wilson et al., 1995] which is here referred to as the Taupo Rift (Fig. 1.3) [after Nicol et al., 2006; Villamor \& Berryman, 2006]. The dense array of normal faults in the Taupo Rift partially accommodates extension and crustal thinning created by the clockwise rotation of the eastern North Island. Seismic reflection studies offshore to the north of the TVZ suggest a basement comprised of extended Mesozoic greywacke where deformation has migrated progressively eastwards (Fig. 1.3) [Davey et al., 1995]. Stretching across the TVZ has resulted in thinning of the quartzofeldspathic crust from $\sim 25 \mathrm{~km}$ to $16 \mathrm{~km}$ [Stratford \& Stern, 2006; Harrison \& White, 2006].

\subsubsection{Taupo Volcanic Zone}

The TVZ is the location of active voluminous Late Quaternary volcanism, characterized by a near complete spectrum of back arc volcanic products, from minor basaltic lavas $(<1 \%)$ to large rhyolitic eruptions $\left(>100 \mathrm{~km}^{3}\right)$ and andesitic volcanic complexes (Fig. 1.3) [Houghton et al., 1995; Wilson et al. 1995]. The active TVZ extends 300 km northnortheast from central North Island to the continental margin in the Bay of Plenty and is part of a broader Central Volcanic Region defined by a wedge-shaped residual gravity anomaly [Stern, 1985; Wilson et al., 1995]. Two styles of volcanism dominate in the 
TVZ; andesite-dacite complexes at the northern and southern ends of the volcanic zone (White Island-Whakatane and Ruapehu-Tongariro respectively) with rhyolitic complexes occupying the central section (Fig. 1.3) [Wilson et al., 1995].

The central rhyolite dominated section is characterized by voluminous pyroclastic and ignimbrite caldera forming eruptions which commenced at c. 1.6 Ma ( 0.4 Ma after the onset of andesitic volcanism) [Wilson et al., 1995]. Volcanic production rates average $\sim 0.28 \mathrm{~m}^{3} / \mathrm{s}$ over the past $340 \mathrm{ka}$, with an estimated total erupted bulk rhyolitic volume of $15-20 \times 10^{3} \mathrm{~km}^{3}$ [Wilson et al., 1995]. Regional ignimbrite flow deposits obscure most of the pre-340 kyr volcanic and fault activity, covering an area of $\sim 15 \times 10^{3} \mathrm{~km}^{2}$. At the surface, all but the youngest of the rhyolitic dome complexes $(<22 \mathrm{ka}$ ) associated with the OVC have been dissected by regional faults. Vents mapped within these extrusive domes are typically aligned parallel to the northeast-southwest trend of Taupo Rift, with a small portion aligned north-south in the Whakamaru area [Wilson et al., 1995; Rowland \& Sibson, 2001; GNS Active Faults database].

The sub-surface location and geometry of calderas within the Central Volcanic Region have primarily been identified through negative gravity anomalies [Rogan, 1982; Wilson et al., 1984; Stern, 1985; Davy \& Caldwell, 1998; Stagpoole \& Bibby, 1999; Milner et al., 2002; Smith et al., 2006; Stratford \& Stern, 2008]. Infill of caldera collapse structures by low density volcanoclastic products is interpreted to account for the majority of the observed gravity anomaly associated with each centre. Regional faults have been implicated in the geometry of several calderas often forming the margins of the major structural collapse [e.g. Davy \& Caldwell, 1998; Milner et al., 2002; Smith et al., 2006].

Geothermal systems are characterized by low resistivities $(\leq 30 \Omega \mathrm{m})$ and are generally spatially correlated with rhyolitic caldera complexes [Bibby et al., 1995; Wilson et al., 1995; Wood, 1995]. The majority of low resistivity areas in the TVZ are semi-circular point sources with average areas of 10-15 $\mathrm{km}^{2}$. High geothermal heat flow $\left(700 \mathrm{~mW} / \mathrm{m}^{2}\right)$ is spatially non-uniform along the length of the TVZ [Stern, 1985; Bibby et al., 1995]. Areas of dense active normal faulting (i.e. spacing $<500 \mathrm{~m}$ ) associated with the Taupo Rift have a noticeable absence of significant geothermal activity and coincide with areas where the crust is coldest and the heat flux low (i.e. approaching zero) [Stern, 1985; Bibby et al., 1995]. 


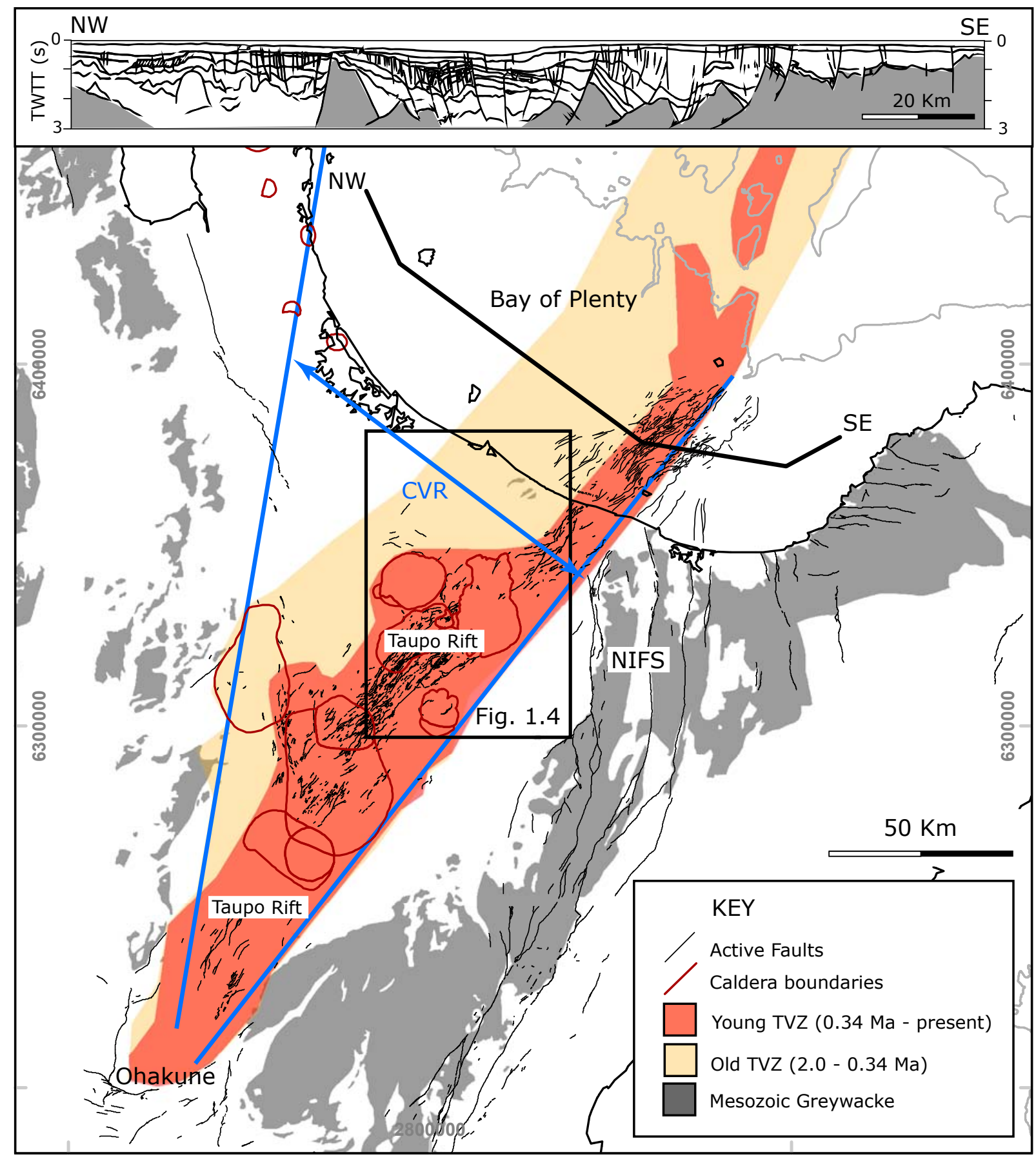

Fig. 1.3. Present volcano-tectonic setting of the North Island of New Zealand. The Taupo Volcanic Zone (TVZ) is the current locus of arc/backarc volcanism and rifting associated with the oblique subduction of the Pacific Plate beneath the Australian Plate east of New Zealand (Fig. 1.2). Volcanic centres of the young TVZ $(<0.34 \mathrm{Ma})$ [Wright, 1992; Wilson et al., 1995] define the eastern boundary of the Central Volcanic Region (CVR) (blue line) [Stern, 1985]. Extension rates across the Taupo Rift ranges from 3-18 mm/yr in a northwest-southeast orientation (blue arrow) [Villamor \& Berryman, 2001 and references therein; Wallace et al., 2004]. Shading in the North Island shows the extent of Mesozoic greywacke basement rocks (grey shading). Inset: Seismic reflection line across the Bay of Plenty (thick black line) is interpreted as a predominantly normally faulted greywacke basement with deformation younging to the east. Abbreviations: NIFS, North Island Fault System. Data: onshore active faults from GNS Active Faults database, offshore faults [Lamarche et al., 2006]. 


\subsubsection{Okataina Volcanic Centre}

The Okataina Volcanic Centre (OVC) is the most recently active of the central TVZ rhyolitic eruptive centres (Fig. 1.4) [Nairn, 2002]. The OVC is a complex of coalescing caldera collapse structures that has been active for the past c. 530 kyr [Leonard unpublished data, 2007]. The volcanic centre has produced at least two large caldera forming events, the $150 \mathrm{~km}^{3}$ Matahina (280 ka) and the $\sim 100 \mathrm{~km}^{3}$ Rotoiti (60 ka) pyroclastic eruptions, along with numerous smaller predominantly rhyolitic eruptions and extrusions [Nairn, 2002]. The recent volcanic activity ( $<22 \mathrm{ka})$ within the complex has been associated with post-caldera rhyolitic dome building culminating in a basaltic fissure eruption across the Tarawera Volcanic Complex in 1886 AD [Smith, 1886; Cole, 1970; Nairn, 2002]. Smith's historical account of the Tarawera eruption provides important constraints on the temporal and spatial interplay between dike intrusion and faulting.

Repeated basaltic injection, in the form of dikes and sills, is inferred to be a key driver for the accumulation and eruption of rhyolitic magma associated with the postcaldera dome complexes within the OVC [Leonard et al., 2002; Nairn et al, 2004]. For example, an arrested basaltic dike has been implicated with contemporaneous rhyolite and hydrothermal eruptions (over $25 \mathrm{~km}$ along strike) associated with the $\sim \mathrm{AD} 1315$ Kaharoa eruption [Leonard et al., 2002; Nairn et al., 2005]. The mixing of different temperature rhyolitic magmas has also been implicated in eruption and dome extrusion processes [Smith et al., 2004]. The crustal volcanic system $~ 6-16 \mathrm{~km}$ beneath the OVC is interpreted to comprise a range of sill-like silicic magma chambers of varying sizes (i.e. between 1 and $>100 \mathrm{~km}^{3}$ ) and compositional diversity that have complex mingling and crystallization histories [e.g. Bannister et al., 2004; Smith et al., 2004; Shane et al., 2005].

\subsubsection{Taupo Rift}

The Taupo Rift is the region of active normal faulting in the TVZ [Rowland \& Sibson, 2001; Villamor \& Berryman, 2001; Acocella et al., 2003; Nicol et al., 2006; Villamor \& Berryman, 2006] extending from Ohakune in the south to the Bay of Plenty coastline in the north (Fig. 1.3). The rift has previously been referred to as the Taupo Fault Belt [Grindley, 1960] and the Ruaumoko Rift [Rowland \& Sibson, 2001]. 


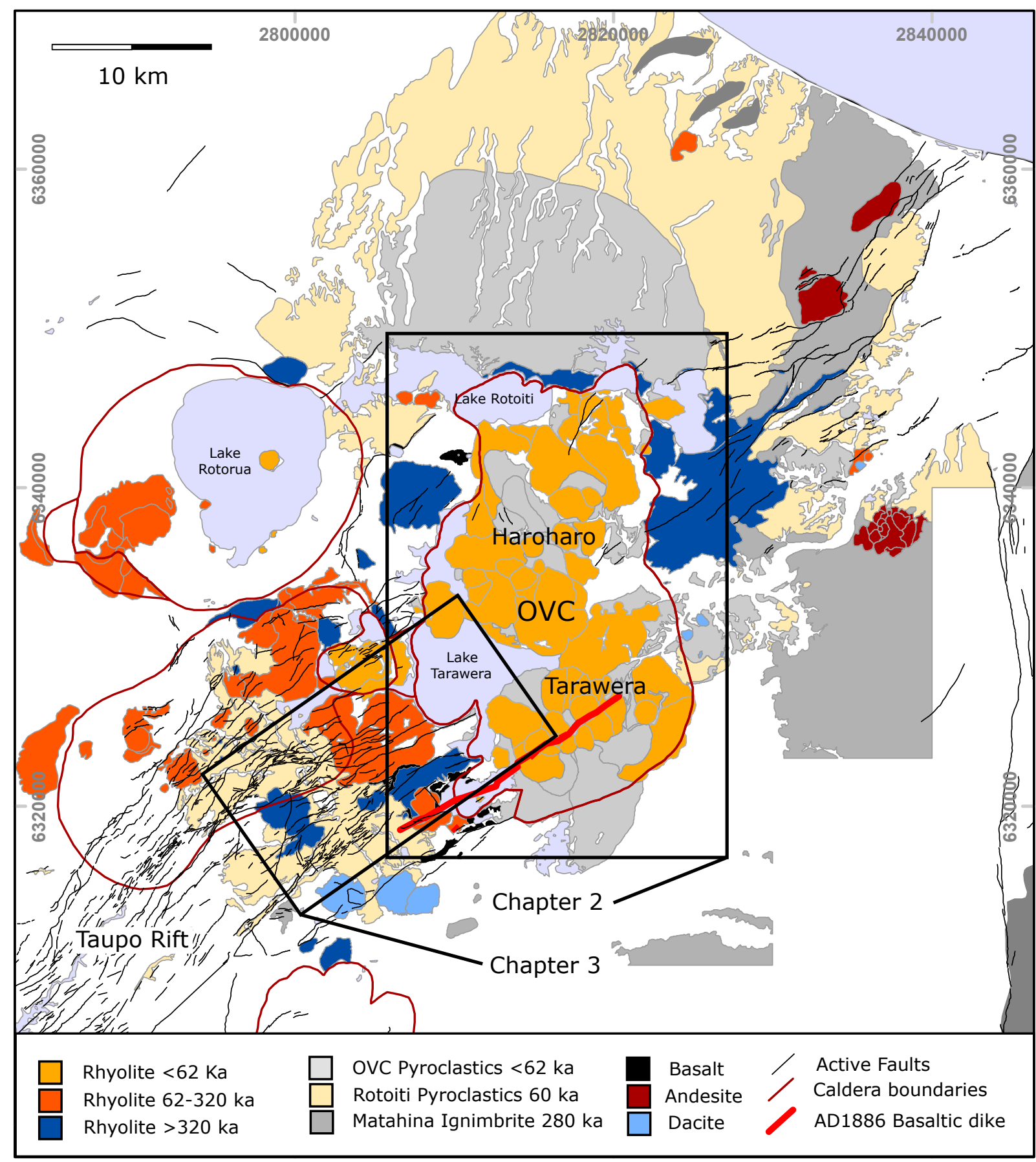

Fig 1.4. Simplified volcanic stratigraphy and chapter study areas (black boxes) of the Okataina Volcanic Centre (OVC) [after Nairn [1989, 2002]. Recent post-caldera dome building $(<22 \mathrm{ka})$ has delineated the Haroharo and Tarawera linear vent zones. These rhyolitic domes are constrained within the topographic margin of the caldera, which is defined in part by precaldera rhyolite lavas up to $531 \pm 5 \mathrm{ka}$ in age [Nairn, 1989, 2002; Leonard unpublished data, 2007]. Matahina (280 ka) and Rotoiti (60 ka) - including Earthquake Flat - ignimbrite and pyroclastic flow deposits erupted during caldera forming events can be seen to the north, east, and west of the volcanic centre [Nairn, 2002]. Research prior to this thesis suggests that faults of the Taupo Rift may terminate against the western topographic caldera margin. The basaltic dike associated with the $1886 \mathrm{AD}$ eruption of Tarawera extends beyond the margin of the volcanic centre terminating near faults of the Taupo Rift [Nairn \& Cole, 1981]. 
Well dated volcanic horizons, where extensive, provide ideal marker horizons with which to map normal faults within the Taupo Rift and to examine their spatial and temporal relations to volcanic centres. Rifting is expressed as a 15-40 km wide zone of predominantly northeast-southwest striking normal faults with topography and scarp heights ranging up to $550 \mathrm{~m}$ (Paeoroa fault) that typically displace volcanic units up to 340 ka in age [Wilson et al., 1995; Villamor \& Berryman, 2001, Nairn, 2002; Acocella et al., 2003; Nicol et al., 2006].

The rift generally forms a well defined graben and along-strike comprises a series of at least five segments [Rowland \& Sibson, 2001; Villamor \& Berryman, 2001; Acocella et al., 2003]. Segment boundaries mark $10-20^{\circ}$ changes in the average strike of the faults and/or 8-10 km left steps in the eastern margin of the active rift [Rowland \& Sibson, 2001; Acocella et al., 2003]. Segment boundaries are inferred at the intersections of the rift and the Whakamaru and Okataina volcanic centres [Wilson et al., 1995; Bibby et al., 1995; Rowland \& Sibson, 2001; Acocella et al., 2003]. The OVC has been interpreted to coincide with a segment boundary that is characterized by a right bend in the rift and that is inferred to be both hard (faults are connected on the scale of the map) and soft linked (no visible connection between faults on the scale of the map with displacement transferred inelastically) across this boundary (Fig. 1.4) [Rowland \& Sibson, 2001; Acocella et al., 2003]. The rift has been the locus for multiple caldera forming events in the Taupo, Whakamaru and Okataina volcanic centres over the past 340 ka [Wilson et al., 1984, 1995].

Sub-surface information on the faulting has been provided by gravity [Modriniak \& Studt, 1959], sparse seismic reflection lines [Woodward, 1988; Davy \& Bibby, 2005; Lamarche et al., 2006; Mouslopoulou et al., 2008], geothermal drill-holes [Wood et al., 2001] and historical earthquakes (e.g. $1987 \mathrm{M}_{\mathrm{L}} 6.3$ Edgecumbe earthquake) [Anderson \& Webb, 1989]. These data suggest that fault-dips shallow from $70-80^{\circ}$ at the ground surface to $\sim 45^{\circ}$ at the base of the seismogenic and brittle crust (i.e. 7-10 km) [Bibby et al., 1995]. The distribution of historical earthquakes along the TVZ is not uniform, with clusters typically associated with the margins of caldera structures, rift segment boundaries, and normal faults; no correlation is observed between the location of geothermal systems and seismicity (Fig. 2.2) [Bibby et al. 1995; Bryan et al., 1999; Rowland \& Sibson, 2001; Hurst et al., 2002].

Slickenside striations [Rowland \& Sibson, 2001; Acocella et al., 2003] and focal mechanisms [Robinson, 1989; Webb \& Anderson, 1998; Hurst et al., 2002] indicate that faulting in the Taupo Rift is predominantly dip slip and approximately perpendicular to 
the plate boundary zone (and the rift), with a possible minor component of dextral shear [e.g. Nairn \& Cole, 1981; Walcott, 1987; Beavan \& Haines, 2001; Acocella et al., 2003]. The principal horizontal extension direction for the TVZ is c. $125-148^{\circ}$ for geodetic and focal mechanism data [Darby et al., 2000; Hurst et al., 2002; Hurst et al., 2008] consistent with an average of c. $137^{\circ}$ for fault slip data [Acocella et al., 2003].

\subsubsection{North Island basement}

Late Permian to Early Cretaceous basement, dominated by greywacke and argillite, underlies much of the North Island [Mortimer, 2004]. Basement rocks of the North Island primarily comprise turbiditic submarine quartozfeldspathic sandstone-mudstone associations and are characterised by a number of steeply dipping (typically $>60^{\circ}$ ) tectonostratigraphic imbricate terranes, which can be locally overprinted by schist or mélange [Mortimer, 2004]. These basement rocks are important because they have the potential to influence the composition of TVZ volcanic rocks, while Mesozoic faults and sedimentary contacts in basement may have influenced the location, geometry, and kinematics of some faults in the Taupo Rift.

Mesozoic terrane boundaries and bedding change in strike from north-northwest adjacent to the Hauraki Rift, northwest of the TVZ, to north-northeast south of Lake Taupo (Fig. 2.2). This change of strike is achieved via a gentle curve and is consistent with clockwise vertical axis rotation of the southern and eastern North Island relative to the northern North Island [Mumme et al., 1989; Nicol et al., 2007]. The curvature of the basement terranes is replicated by the strike of the main Tertiary faults west, and the active faults of the North Island Fault System to the east (previously the North Island Dextral Fault Belt), of the Central Volcanic Region (Fig. 1.4). The location and orientations of terrane boundaries through the Central Volcanic Region are ambiguous due to the absence of outcrop (Fig. 2.2). Interpretation of a terrane boundary on the eastern margin of the TVZ is consistent with the northward continuation of the Jurassic Kaweka terrane beneath the Kaingaroa Plateau as inferred through residual gravity and magnetotelluric studies [Bibby et al., 1995; Stagpoole \& Bibby, 1999; Mortimer, 2006]. The structural fabric of the Mesozoic basement is approximately parallel the strike of the Taupo Rift south of Lake Taupo. North of Lake Taupo the basement fabric strikes north to north-northwest and diverges from the strike of rift faults by up to $60^{\circ}$. The oblique intersection of the primary rift faults and basement fabric may have important implications for the locations and geometries of faults, caldera locations and the linear alignment of volcanic vents (see Chapter 4). 
One of the key debates relating to the development of the TVZ is the degree to which pre-existing Mesozoic basement have been replaced by magmas generated by back arc volcanism [e.g. Stern, 1985; Wilson et al, 1995]. Stern [1985, 1987] argues, on the basis of heat flow and andesitic arc migration, for the replacement of approximately two thirds of the current quartzofeldspathic crustal thickness by intermediate compositions (e.g. andesite/diorite) over an area of $5000 \mathrm{~km}^{2}$. Previous geophysical studies (e.g. seismic refraction and gravity studies) are ambiguous in relation to distinguishing the dominant crustal lithology as both Mesozoic greywacke and intermediate volcanic compositions have similar densities [Stern, 1985, 1987]. Seismic refraction studies modelled on the basis of laterally uniform velocity layers suggest Pwave velocities $(5.5 \mathrm{~km} / \mathrm{s})$, consistent with a Mesozoic, andesitic, or compacted silicic basement, are reached at depths of $\sim 2$ km [Robinson et al., 1981; Stern, 1986]. Drillhole information from the eastern TVZ is also ambiguous as both andesite/diorite and Mesozoic greywacke have been intersected at depths $>2 \mathrm{~km}$ in geothermal drill-holes with recent exploration in the Mangakino Caldera intersecting $3.2 \mathrm{~km}$ of welded ignimbrite [Stern, 1985, 1987; Spinks et al., 2005].

Wilson et al. [1995] argues for a basement lithology comprised of predominantly Mesozoic greywacke on the basis of the composition, duration, and location of volcanism in the young TVZ (0.34 Ma to present). This interpretation is supported by recent zircon [Charlier et al., 2005] and magnetotelluric studies [Heise et al., 2007] in and adjacent to the Taupo Volcanic Centre. Within a $20 \mathrm{~km}$ radius of the OVC, Mesozoic greywacke outcrops to the north, south, and east and is intersected at depths of $\sim 1 \mathrm{~km}$ in geothermal drill-holes within the rift (Fig. 1.4) [e.g. Nairn \& Beanland, 1989; Nairn 2002]. Therefore, the available data support the view that the arc/back arc volcanic rocks in the Taupo and Okataina volcanic centres pass through and incorporate Mesozoic greywacke terrane(s) that may influence the composition, style, and location of volcanism in these centres [e.g. Cole, 1990; Wilson et al., 1995; Charlier et al., 2005].

\subsection{Thesis organisation and contents}

To address the primary questions outlined earlier in the chapter, the thesis focuses on OVC-Taupo Rift interaction and has been formulated in five parts: (1) Introduction (Chapter 1); (2) Fault controls on the geometry and location of the Okataina Caldera (Chapter 2); (3) Impact of dike intrusion and caldera collapse on the accumulation of fault displacements in the Okataina Volcanic Centre (Chapter 3); (4) Relationships 
between faulting and volcanism in the Okataina Volcanic Centre (Chapter 4); (5) Conclusions (Chapter 5).

This thesis has been written in a format so that each of the main chapters (2-4) can form the basis of 3 manuscripts suitable for publication in international geoscience journals. The references cited in each chapter will be listed at the end of the thesis. Appendices relating to data collection and analysis can be found at the back of the thesis and supplement Chapters 2 and 3.

In order to address key questions proposed in this study, published data have been incorporated into the analysis where appropriate. This thesis contains new data and analysis together with reinterpretations of existing data and observations. New gravity information has enhanced pre-existing data coverage across the OVC [e.g. Stagpoole \& Bibby, 1999]. These gravity data have been collected and processed to a standard that can be incorporated into the GNS Land Gravity Database; a previous gravity study of the OVC [Rogan, 1982] adopted a gravity reduction technique inconsistent with the GNS Land Gravity Database and therefore is unable to be included in the current regional data set. Fault displacement measurements using a TOPSAR-derived digital elevation model are new and consistent with previous fault displacement studies in the area [Villamor \& Berryman, 2001]. All existing data and interpretations are fully referenced. The purpose and contents of the three principal thesis chapters (i.e. 2-4) are briefly summarized below.

(2) Fault controls on the location and geometry of the Okataina Caldera.

The focus of Chapter 2 is to examine the spatial and temporal relationships between a multiple collapse caldera and a continental rift system. The chapter establishes the subsurface geometries of the Okataina Caldera structure and its spatial relations to the Taupo Rift. I assess whether rift faults terminate at the caldera margin, or cross cut the caldera structure, and to what extent faults have influenced the location and/or trend of volcanic features (e.g. linear vent alignments and caldera shape).

To investigate the first order geometry of the caldera structure, the rift and potential basement fabric, new gravity data have been collected adjacent to the caldera and combined with an existing regional gravity data set [GNS Land Gravity Database]. A preliminary interpretation of magnetotelluric data [Bibby, unpublished data 2007] is used to complement and assist 1 and 21/2D gravity modelling. Seismic reflection data of Davy \& Bibby [2005] is reinterpreted beneath Lake Tarawera to constrain the 
geometries and locations of subsurface faults and volcanic collapse structures within the topographic margin of the caldera. These two data sets combined with active fault trace mapping and published physical volcanic data permit different published models proposed for the control of Okataina Caldera geometry to be tested.

(3) Impact of dike intrusion and caldera collapse on the accumulation of fault displacements in the Okataina Volcanic Centre.

Chapter 3 addresses volcano-tectonic interactions between the Okataina volcanic system and the Taupo Rift by investigating vertical fault displacements over a range of timescales from the historic $1886 \mathrm{AD}$ Tarawera eruption to 500 ka. The key questions addressed here are whether volcanic processes (i.e. dike intrusion and caldera collapse) have influenced the growth and accumulation of displacements on faults within, and adjacent to, the OVC. Displacement analysis has been used to make inferences about whether faulting is principally driven by magmatic or tectonic processes.

New fault displacement data from the southwest margin of the OVC is analysed in relation to historic reports of ground deformation associated with the Paeroa Fault during the 1886 AD Tarawera basaltic dike eruption [Smith, 1886]. Fault displacement data are combined with reinterpreted seismic reflection data [Davy \& Bibby, 2005] to measure and analyse changes in fault displacements along the rift and into the caldera associated with the $60 \mathrm{ka} 100 \mathrm{~km}^{3}$ Rotoiti Pyroclastic eruption [Nairn, 2002]. New and existing gravity data are then utilised to establish the relationship between displacements that accrues on rift faults during caldera collapse and due to tectonic extension across the rift.

(4) Relationships between faulting and volcanism in the Okataina Volcanic Centre.

Chapter 4 examines the relations between the geometries and locations of faulting and volcanism in the OVC. The question posed in this chapter is: to what extent has the OVC formed in response to local, magmatically driven extension and/or whether the volcanic centre is a product of the interaction between structural fabrics and the principal horizontal extension direction.

Published geological and geophysical principal horizontal extension (PHE) direction indictors are collated and analysed along the length of the Taupo Rift. PHE 
direction data are combined with an interpretation of faulting in the OVC [Chapter 2] to formulate a model that accounts for the observed structural and volcanic relationships of the Okataina region. The faulting-volcanism model developed may have implications for the impact of pre-existing basement structures and/or rift faults on other TVZ volcanic centres. 
CHAPTER TWO

FAULT CONTROLS ON THE GEOMETRY AND LOCATION OF THE OKATAINA CALDERA 


\subsection{Introduction}

Formation of ash-flow calderas through roof collapse over an underlying shallow magma reservoir is a widely recognised process accompanying explosive eruptions greater than a few cubic kilometres [Lipman, 1997]. Caldera forming events in the TVZ typically erupt 30-500 $\mathrm{km}^{3}$ (dense rock equivalent) of rhyolitic material in the form of airfall and ash flow deposits (i.e. pyroclastic and ignimbrite flows) [Wilson et al., 1984; Houghton et al., 1995]. While not definitive, combined seismic, gravity, and magnetotelluric studies support the inference that underlying large silicic volcanic systems at various depth are partially molten regions that are ultimately driven by basaltic flux from the mantle (i.e. shallow and deep plutons) [e.g. Annen et al., 2002; Bachmann et al., 2007].

Caldera structures in rift environments have a variety of geometries from subcircular to elongate and have various styles of collapse (e.g. piston, piecemeal, or trapdoor) [Cole et al., 2005]. However, the processes resulting in rhyolitic caldera formation within extending continental lithosphere remain uncertain despite many local and regional studies. The diverse subsidence geometries for explosive rhyolitic calderas are inferred to reflect the varying sizes and depth to the source magma chamber along with regional tectonic influences and/or prior roof and collapse margin trends [Lipman, 1997; Cole et al., 2005 and references therein]. Therefore regional active faults, preexisting structural fabrics, stress conditions (both local and regional), and magma chamber geometry may all influence the location and geometry of caldera collapse structures [e.g. Wilson et al., 1984; Fergusson et al., 1994; Lipman, 1997; Gudmundsson, 1998; Moore \& Kokelaar, 1998; Acocella et al., 2002; Prejean et al., 2002; Bosworth, 2003; Cole et al., 2005].

End-member models proposed to account for caldera collapse geometries (surface and sub-surface) range from purely magmatic [e.g. Bosworth et al., 2003] to dominantly fault controlled (Fig. 2.1) [e.g. Fergusson et al., 1994]. A relationship between the regional extension direction and fault orientation [e.g. Acocella et al., 2002; Prejean et al., 2002] may, for example, assist in the ascent and localization of magma bodies in the shallow crust by producing regions of low pressure and/or accommodation space in the mid to lower crust [e.g. Corti et al., 2003; Canon-Tapia \& Walker, 2004].

To understand the interrelations between caldera and rift formation in extending continental crust, the intersection of the Taupo Rift and Okataina Caldera has been examined in detail (Fig. 1.4). 

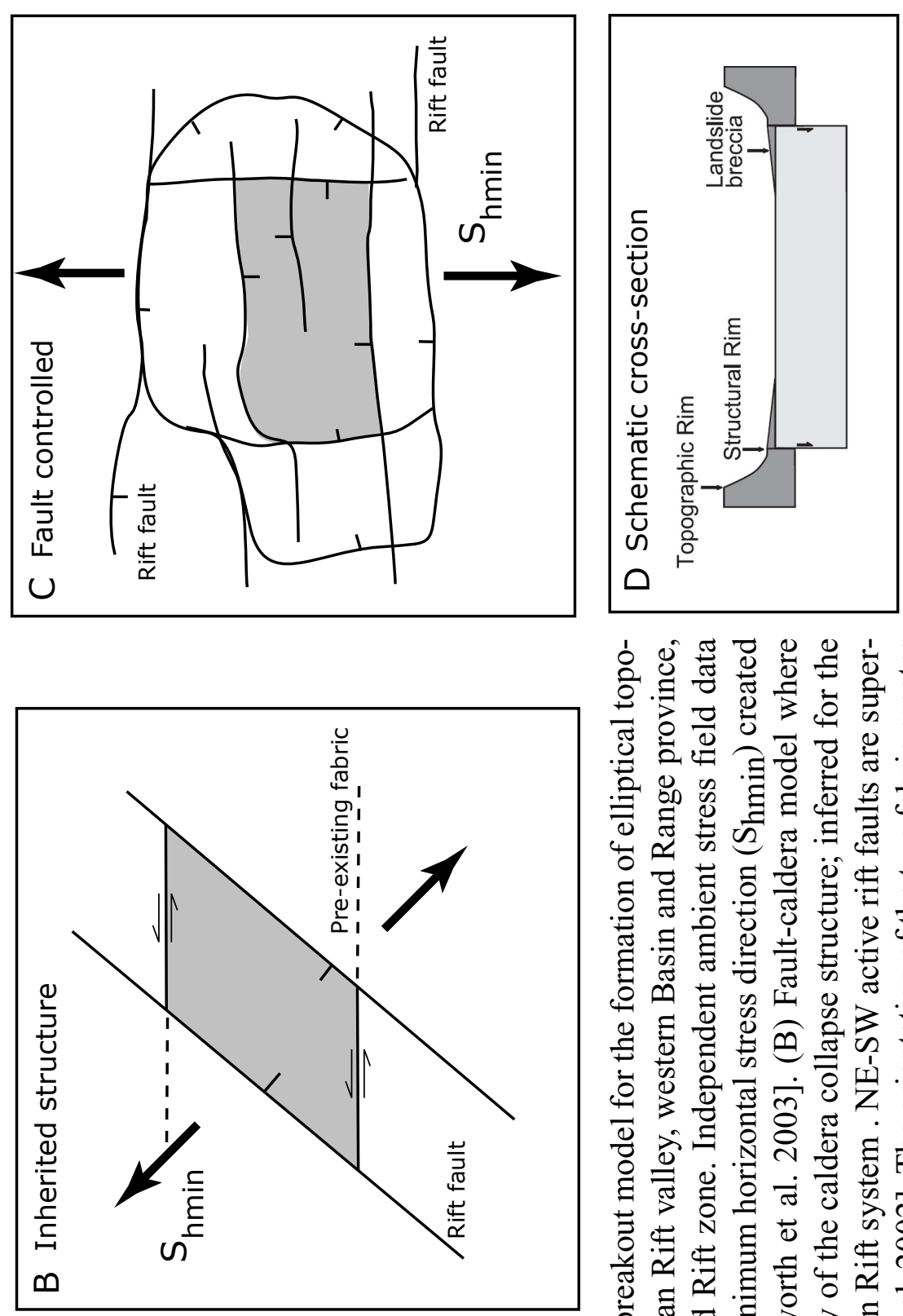

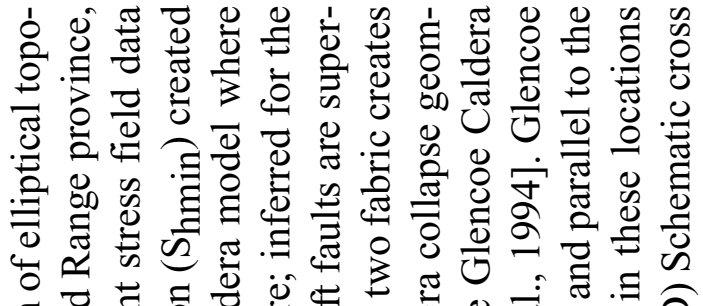

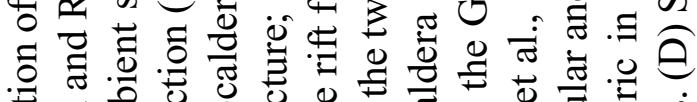

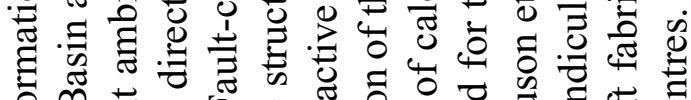
రొ

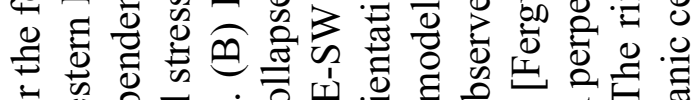

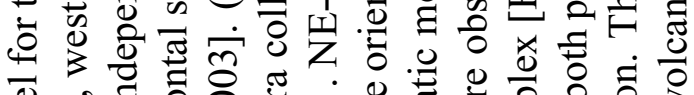

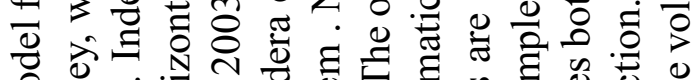
严 류류

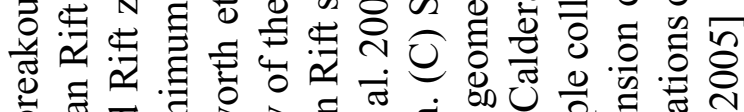
పี

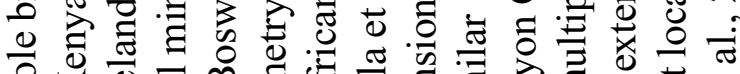

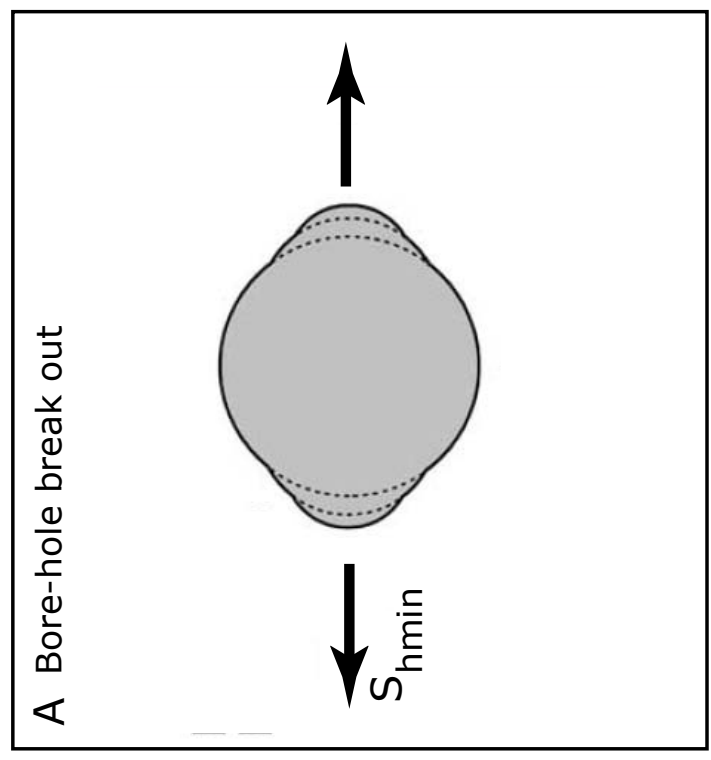

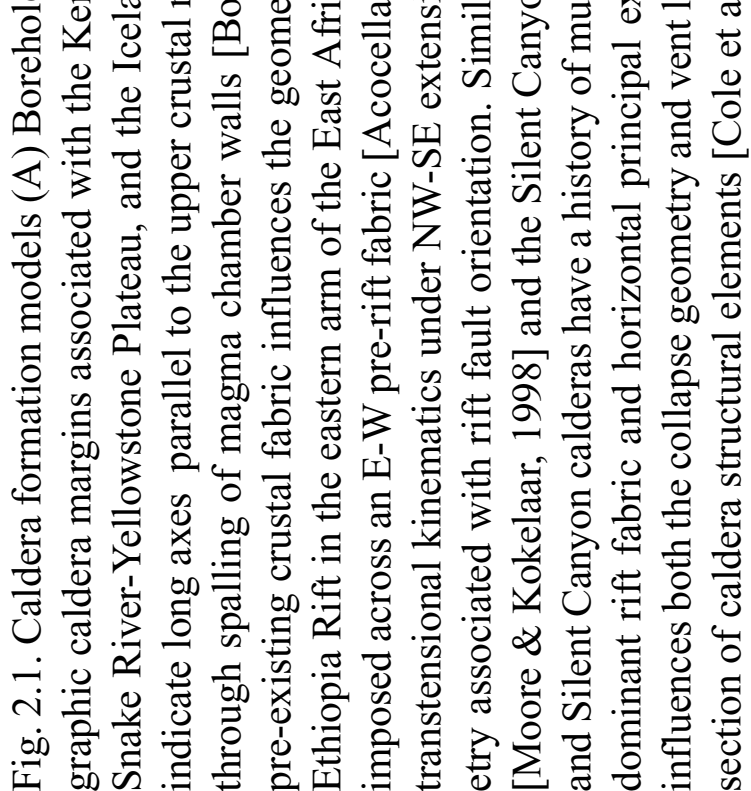



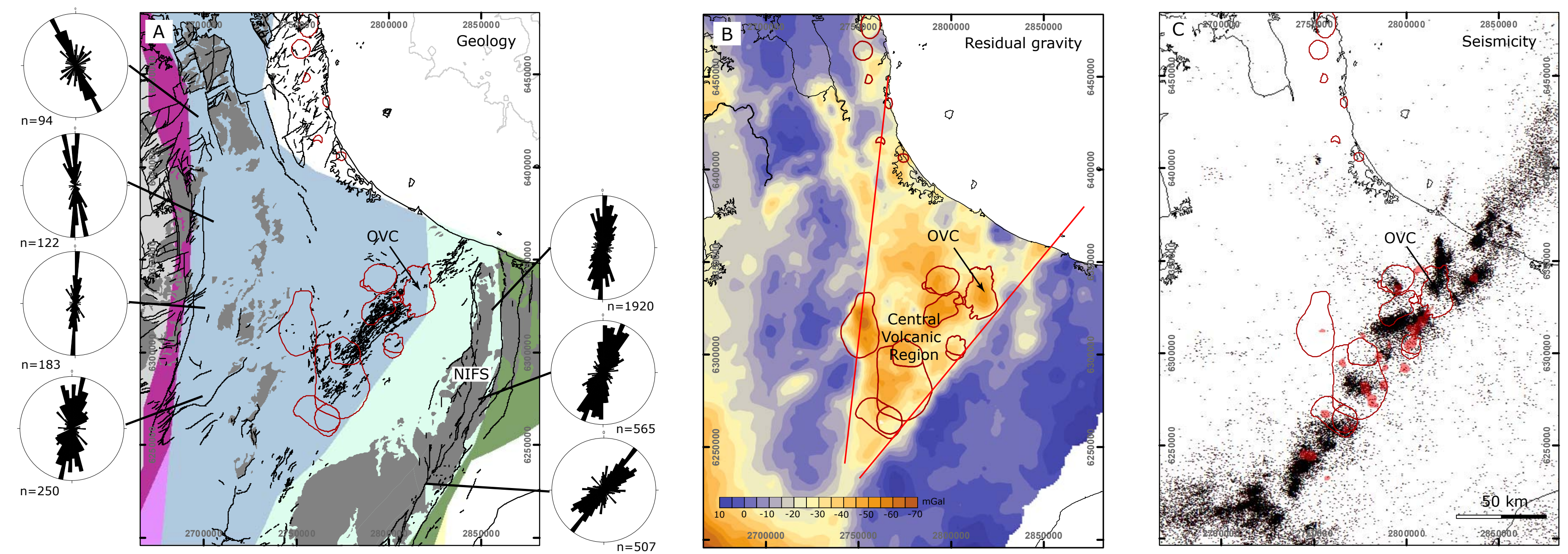

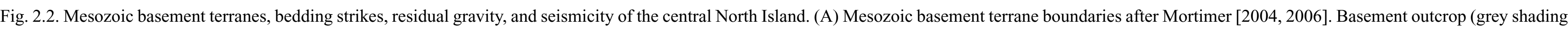

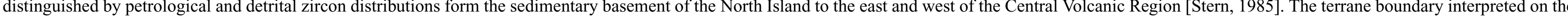

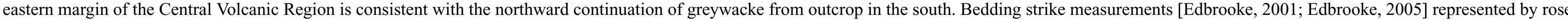

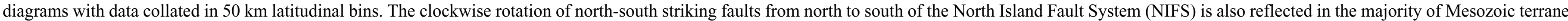

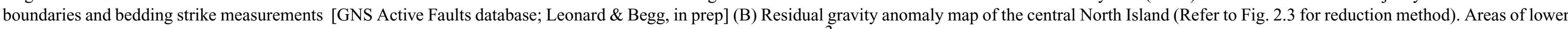

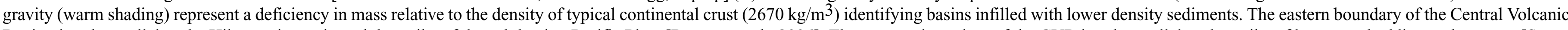

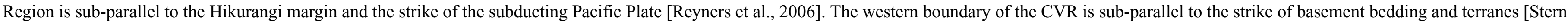

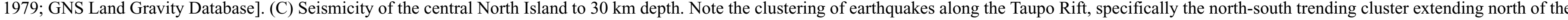
OVC [GEONET Earthquake Catalogue]. Areas of low resistiviy (red shading) corresponding to TVZ geothermal areas [Bibby et al., 1995]. 
This chapter investigates the geometry of the Okataina Caldera complex and rift using analyses of surface faulting patterns, published 1:50 000 geological maps [Nairn, 1989, 2002], reinterpreted seismic reflection lines [Davy \& Bibby, 2005], and 21/2D gravity modelling of new and existing gravity data sets [GNS Land Gravity Database]. These data sets make the OVC an ideal location for testing the interrelationship between faulting and two rhyolitic caldera formation events at 280 and $60 \mathrm{ka}$, which occurred within the young continental Taupo Rift (< 2 Ma) (Fig. 1.3) [Wilson et al., 1995; Nairn, 2002]. The combination of these geological and geophysical data contribute to a structural model for the caldera complex and rift, showing that the geometry and location of the caldera structure has been strongly influenced by pre-existing rift faults and a deeper tectonic fabric within Mesozoic basement rocks.

\subsection{Methods \& Data}

Caldera structures in the TVZ can be identified and modelled using gravity data, while detailed information on faulting is provided by topographic analysis of fault scarps. The first order structure of the caldera complex and rift has been assessed through new and pre-existing geological (e.g. volcanic unit distribution and rift architecture [Nairn, 2002; Rowland \& Sibson, 2001; Acocella et al., 2003; this study]) and geophysical data (e.g. seismicity, resistivity, and magnetotelluric data [Bibby et al., 1995; GEONET Earthquake catalogue; Bibby unpublished data, 2007; Hurst et al., 2008]) in association with digital elevation model and gravity studies [this study]. To collate, integrate, and compare the different data sets, they have all been spatially referenced into New Zealand Map Grid coordinates and input into Geographical Information Systems (GIS).

In the following sections the techniques used to acquire, process and analyse the principal data sets utilized in this chapter are described. These methods are: i) gravity, ii) seismic reflection lines, and iii) topographic analysis. Each of the methods provides information on the caldera and/or faults over different depth ranges from kilometres (gravity), to 100's of meters (seismic reflection), to the ground surface (topography).

\subsubsection{Gravity}

Gravity surveying is used to investigate subsurface geology using the variations in the Earth's gravitational field arising from density contrasts between subsurface rocks. A rock unit of different density from its surroundings represents a subsurface zone of anomalous mass and causes a local perturbation in the gravitational field known as a gravity anomaly [Kearey et al., 2002]. Gravity anomaly data can provide useful 
information on the first order geometry of a caldera collapse structure from the gradients associated with the maximum anomaly and minimum depth estimations to top basement. Gravity surveying has been used to map top basement and caldera collapse structures in the Central Volcanic Region which underlie thick (e.g. $>2 \mathrm{~km}$ ) accumulations of Late Quaternary ( $<400 \mathrm{ka}$ ) low-density volcanic products (Fig. 2.2) [e.g. Modriniak \& Studt, 1959; Rogan, 1982; Wilson et al., 1984; Stern, 1985, 1987; Stagpoole, 1994; Davy \& Caldwell, 1998; Smith et al., 2006; Stratford \& Stern, 2008].

An existing onshore gravity dataset covering an area of $60 \times 10^{3} \mathrm{~km}^{2}(13560$ stations) has been extracted from the GNS Land Gravity Database for the central North Island (Fig. 2.3). These gravity data, collected over the past 60 years by numerous workers, are tied to the New Zealand Primary Gravity Network and reduced to Bouguer anomalies using the method of Reilly [1972] and a crustal density of $2670 \mathrm{~kg} / \mathrm{m}^{3}$.

Prior to this study Rogan [1980] completed a comprehensive gravity study of the OVC. However, the reduction method of Rogan [1980] is inconsistent with the methods of the GNS Land Gravity Database and therefore Rogan's measurements have been excluded from this study as they could not be integrated into the regional dataset with confidence. An independent analysis of Rogan's gravity data produced first order results comparable to those presented in this study (Fig. 6.1). The GNS Land Gravity Database (i.e. excluding Rogan's data) in the study area contains 40 gravity measurements within the topographic caldera margin of the OVC defining an elongate residual anomaly of 45 mGal over an area of 10 x 25 km [Stagpoole \& Bibby, 1999; Nairn, 2002].

During the course of this study a total of 108 new gravity measurements were collected in the vicinity of the OVC using a La Coste and Romburg G Meter (at $\sim 1 \mathrm{~km}$ spacing) (Fig. 2.3). These new data provide a greater density of stations in central and southern part of the volcanic complex, and enable transects to be constructed for gravity modelling across the Okataina Caldera. A gravity survey transect across the southern caldera boundary, when combined with preliminary interpretation of magnetotelluric data [Bibby unpublished data, 2007], provides additional constraints for the gravity models. Differential GPS tied to a base station of known elevation provided altitude control for each new gravity station (to an accuracy of $\pm 15 \mathrm{~cm}$ ). These new gravity data were tied to the New Zealand Primary Gravity Station 156 (Reporoa) and reduced via the method of Reilly [1972] using a density of $2670 \mathrm{~kg} / \mathrm{m}^{3}$ for Bouguer and Terrain corrections, consistent with GNS Land Gravity Database. Terrain corrections have been applied to each measurement to a distance of $22.9 \mathrm{~km}$. 


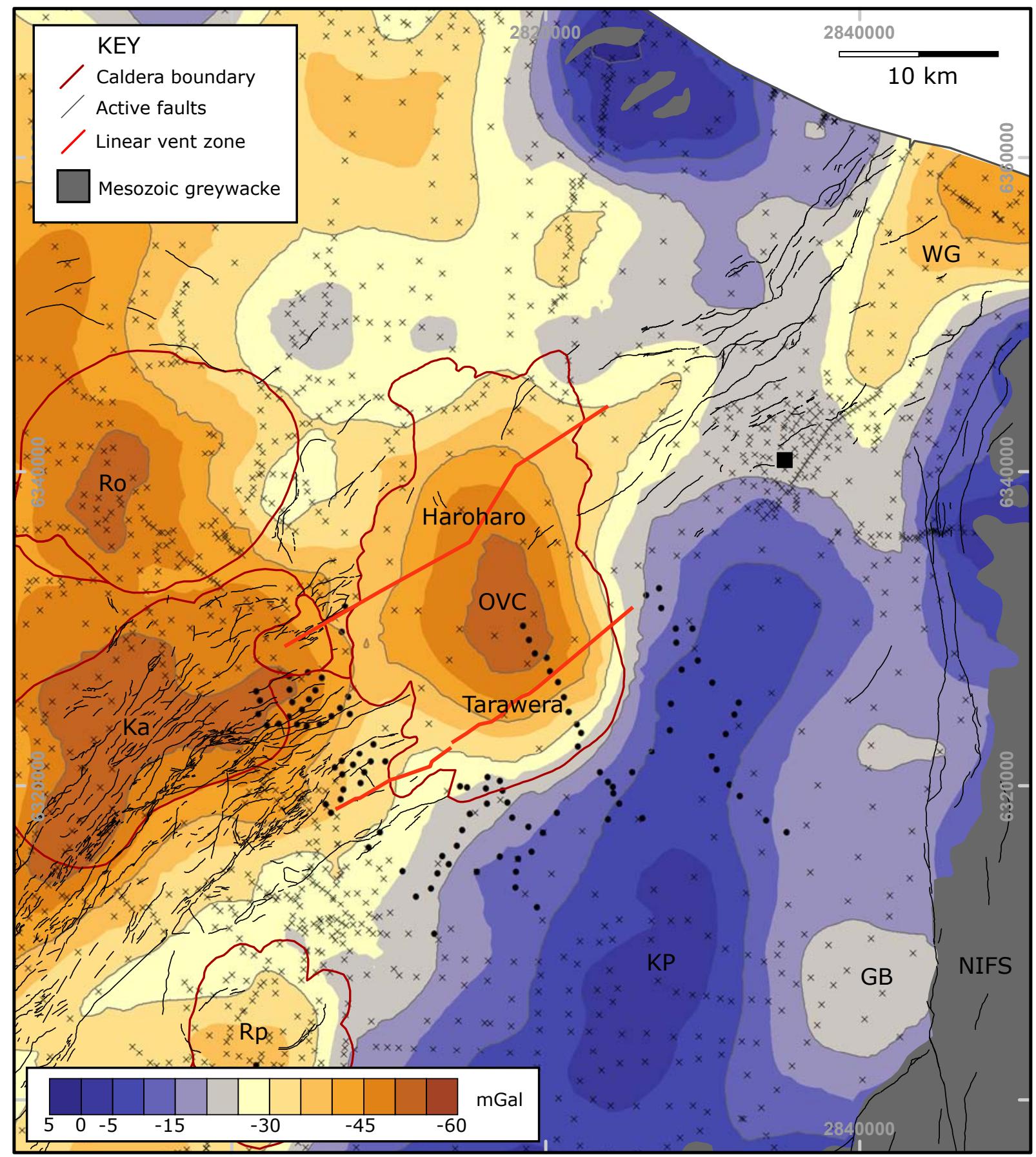

Fig. 2.3. Residual gravity anomaly map of the Okataina Volcanic Centre (OVC). Data are from new gravity measurements (filled circles) and the GNS Land Gravity Database (crosses) reduced to Bouguer anomalies using the method of Reilly [1972]. A density of $2670 \mathrm{~kg} / \mathrm{m}^{3}$ was used for the Bouguer and Terrain corrections. Residual gravity anomalies have been obtained by the removal of the regional field of Stern [1979] from the Bouguer anomalies. An elongate $-50 \mathrm{mGal}$ gravity anomaly is observed within the topographic margin of the OVC, bounded by the Tarawera and Haroharo linear vent zones [Nairn, 1989] and oblique to the trend of active faults of the Taupo Rift. Mesozoic greywacke basement (grey shading) outcrops to the north and east of the OVC has been intersected at depths of $\sim 1 \mathrm{~km}$ in the Kawerau geothermal field (black filled square) and is interpreted to underlie the ignimbrites of the Kaingaroa Plateau [Bibby et al., 1995]. Abbreviations: TVZ volcanic centres: Ro, Rotorua, Ka, Kapenga; Rp, Reporoa [Wilson et al., 1995]; KP, Kaingaroa Plateau; GB, Galatea Basin; WG, Whakatane Graben; NIFS, North Island Fault System. 
For further details on the gravity reduction method refer to Appendix I. These new gravity data were combined with the existing GNS Land Gravity Database to produce a regional Bouguer anomaly dataset.

Gravity anomalies represent the departure of the observed gravity field from a standard uniform Earth model. The effect of low density material in the upper crust combined with density variations in the deeper structure of the Earth result in the gravity anomalies observed in the TVZ. Long wavelength gravity anomalies (e.g. > 100 $\mathrm{km}$ ) from the deep structure within the Earth are considered part of the regional gravity field. A third-order, two-way, regional gravity field for the central North Island calculated by Stern [1979] is used here. Stern's long wavelength signal is derived from Bouguer gravity anomalies observed either side of the Central Volcanic Region on a geologically uniform Mesozoic greywacke basement (Fig. 2.2, Table 2.1). Following the method of Stagpoole \& Bibby [1999] this regional gravity field has been subtracted from the Bouguer gravity anomaly data (GNS Land Gravity Database and this study) to provide a residual gravity anomaly dataset (Fig. 2.3 and 4.1).

\subsubsection{Interpretation uncertainties}

The interpretation of gravity anomalies is dependent on many assumptions as there are few geological constraints on the composition and density structure within the Okataina Caldera. The uncertainties associated with the interpretation of gravity observations relate to uncorrelated errors and systematic errors.

Uncorrelated errors relate to the accuracy of the gravity observation, its location and altitude at each station. The estimated accuracy of the calculated Bouguer anomaly data (i.e. combination of gravity and altitude measurements) from this study is \pm 0.1 $\mathrm{mGal}$ and is predominantly due to uncertainty in near zone terrain correction estimates (Hammer zone $\mathrm{D}<170 \mathrm{~m}$ ). The accuracy of gravity anomaly data from the GNS Land Gravity Database is primarily dependent on the method used for altitude determination. Errors of up to $\pm 3 \mathrm{mGal}$ could be expected for data where altitude has been derived from barometric levelling (i.e. with estimated altitude errors of $\pm 10 \mathrm{~m}$ ). All stations within the GNS Land Gravity Database have been checked against a 10m grid digital elevation model (DEM) and removed when recorded and DEM heights differ by $>20 \mathrm{~m}$. Uncorrelated errors are considered small compared to systematic errors resulting from the gravity interpretation.

Uncertainties in the overall interpretation are considered to be systematic errors (i.e. repeatable) and include the non-uniqueness of gravity interpretation. Gravity 
models are non-unique due to the infinite combination of density structures that fit the observed data. For example, small near-surface features with high density contrasts can have the same gravity effect as large, deep structures with small density contrasts [e.g. Rogan, 1980; Stern, 1982]. Lateral variations in density can also have a profound effect on the interpretation, especially in volcanic regions where rock compositions can change rapidly. Rogan [1980] suggested that for a given gravity anomaly, a model fit of $\pm 3 \mathrm{mGal}$ to the observations is acceptable due to the possible effect of unknown variable density contrasts at depth. Other systematic errors that may affect the interpretation of gravity observations include the validity of the regional gravity field and errors in the choice of the densities for the volcanic and basement rocks used in the models.

\subsubsection{Rock properties}

The densities of rocks used in gravity modelling have been constrained by surface geology [Nairn, 2002], Kawerau geothermal drill-hole rock properties, preliminary magnetotelluric studies [Bibby unpublished data, 2007], TVZ rock property analysis (Fig. 6.3, 6.4 and 6.5), and previous TVZ gravity studies (e.g. Modriniak \& Studt, 1959; Rogan, 1982; Stagpoole, 1994). Table 2.1 provides a summary of TVZ rock density data from the GNS PETLAB Database.

Subsurface density data used to help constrain the gravity interpretation originate from geothermal wells drilled on the eastern side of the TVZ to depths of $\sim 2.5$ km (Fig. 2.4). Densification effects have long been noted for geothermal sites [e.g. Stern, 1982; Bibby et al., 1995] and any density analysis with depth using these data alone may therefore have a bias (Fig. 6.4). Geothermal drill-holes wells typically show a general increase in rock density with depth, although the precise form of this relationship varies between wells (Fig. 2.4 and 6.5). To test this, an independent dataset of basement depths (with associated residual gravity values) was modelled from drillhole and geophysical data collected outside of geothermal areas (Table 6.2) using an exponentially decreasing density contrast with depth function after Cordell [1973].

The concept of basement used in this study relates to rock density that is equivalent to Mesozoic greywacke $\left(2670 \mathrm{~kg} / \mathrm{m}^{3}\right)$. This basement definition makes no assumption of the composition of the rock at depth. Independent geological and/or geophysical constraints are required to interpret the composition of basement in any particular region due to the highly variable lateral changes in rift structure and 
volcanism within the TVZ. For further discussion of the limitations for seismic and gravity studies in defining basement in the TVZ refer to Stern [1986].

\begin{tabular}{|c|c|c|c|c|c|}
\hline $\begin{array}{c}\text { Stratigraphic } \\
\text { unit }\end{array}$ & $\begin{array}{c}\text { Whakamaru } \\
\text { Ignimbrite }\end{array}$ & $\begin{array}{c}\text { Rangitaiki } \\
\text { Ignimbrite }\end{array}$ & $\begin{array}{c}\text { Matahina } \\
\text { Ignimbrite }\end{array}$ & $\begin{array}{c}\text { Mamaku } \\
\text { Ignimbrite }\end{array}$ & $\begin{array}{c}\text { Rotoiti } \\
\text { Breccia }\end{array}$ \\
\hline Age (ka) & $340 \pm 10$ & $320 \pm 10$ & $280 \pm 10$ & $220 \pm 10$ & $64 \pm 4$ \\
\hline $\begin{array}{c}\text { Mean surface } \\
\text { density (kg/m })\end{array}$ & 2160 & 2257 & 2021 & 1813 & 1841 \\
\hline $\begin{array}{c}\text { Std. Dev. } \\
\text { [sample number] }\end{array}$ & $184[27]$ & $27[6]$ & $185[16]$ & $335[4]$ & $258[12]$ \\
\hline $\begin{array}{c}\text { Mean drill-hole } \\
\text { density (kg/m) }\end{array}$ & 2201 & 2375 & 2253 & - & 2244 \\
\hline $\begin{array}{c}\text { Std. Dev. } \\
\text { [sample number] }\end{array}$ & $153[61]$ & $149[49]$ & $30[4]$ & - & $86[5]$ \\
\hline $\begin{array}{c}\text { Mean drill-hole } \\
\text { depth (m) }\end{array}$ & 165 & 845 & 149 & - & 975 \\
\hline $\begin{array}{c}\text { Max. drill-hole } \\
\text { depth (m) }\end{array}$ & 1555 & 1340 & 230 & - & 1038 \\
\hline
\end{tabular}

\begin{tabular}{|c|c|c|c|c|c|}
\hline $\begin{array}{c}\text { Stratigraphic } \\
\text { unit }\end{array}$ & $\begin{array}{c}\text { Haparangi } \\
\text { Rhyolite }\end{array}$ & $\begin{array}{c}\text { TVZ } \\
\text { Ignimbrite }\end{array}$ & $\begin{array}{c}\text { TVZ } \\
\text { Tuff }\end{array}$ & $\begin{array}{c}\text { TVZ } \\
\text { andesite/diorite }\end{array}$ & $\begin{array}{c}\text { Mesozoic } \\
\text { Greywacke }\end{array}$ \\
\hline Age (ka) & - & - & - & - & - \\
\hline $\begin{array}{c}\text { Mean surface } \\
\text { density (kg/m })\end{array}$ & 2154 & 2161 & 1934 & 2510 & 2628 \\
\hline $\begin{array}{c}\text { Std. Dev. } \\
\text { [sample number] }\end{array}$ & $237[65]$ & $347[400]$ & $248[41]$ & $176[55]$ & $43[11]$ \\
\hline $\begin{array}{c}\text { Mean drill-hole } \\
\text { density (kg/m) }\end{array}$ & 2176 & 2135 & 2079 & 2462 & 2603 \\
\hline $\begin{array}{c}\text { Std. Dev. } \\
\text { [sample number] }\end{array}$ & $211[213]$ & $281[2722]$ & $262[601]$ & $145[105]$ & $40[21]$ \\
\hline $\begin{array}{c}\text { Mean drill-hole } \\
\text { depth (m) }\end{array}$ & 522 & 587 & 663 & 1232 & 1493 \\
\hline $\begin{array}{c}\text { Max. drill-hole } \\
\text { depth (m) }\end{array}$ & 990 & 1855 & 2225 & 2727 & 2582 \\
\hline
\end{tabular}

Table 2.1: TVZ rock density analysis. Rock data from GNS PETLAB Database. Age data from Wilson et al. [1995]. 

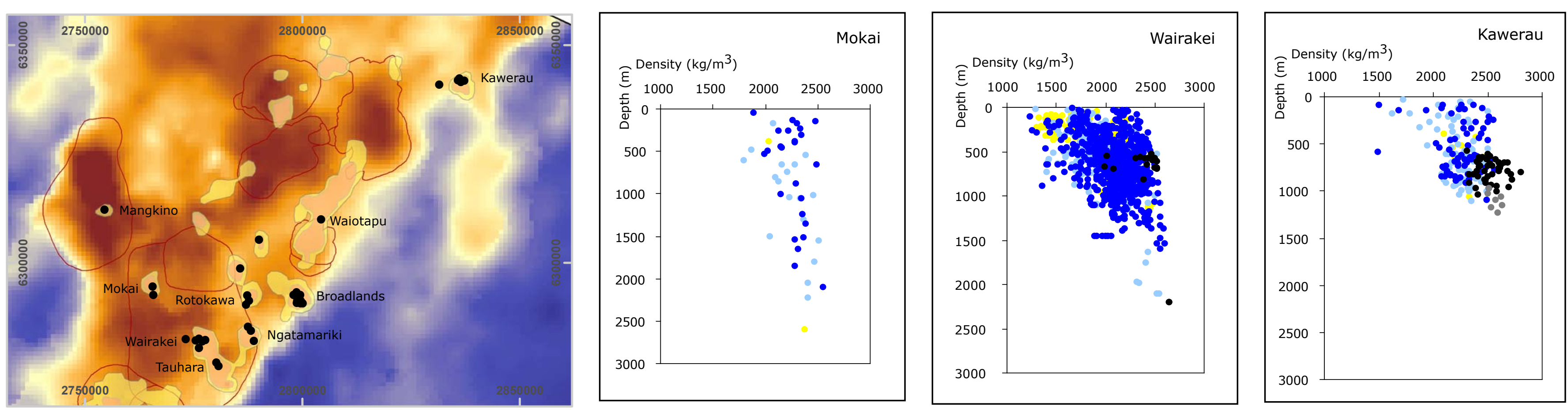

\begin{tabular}{|l|}
\hline KEY \\
- Sediments \\
- Tuff/Breccia \\
- Rhyolite/Ignimbrite \\
- Dacite \\
- Andesite \\
$\square$ Greywacke \\
Areas of low resistivity \\
Bibby et al. [1995] \\
\hline
\end{tabular}
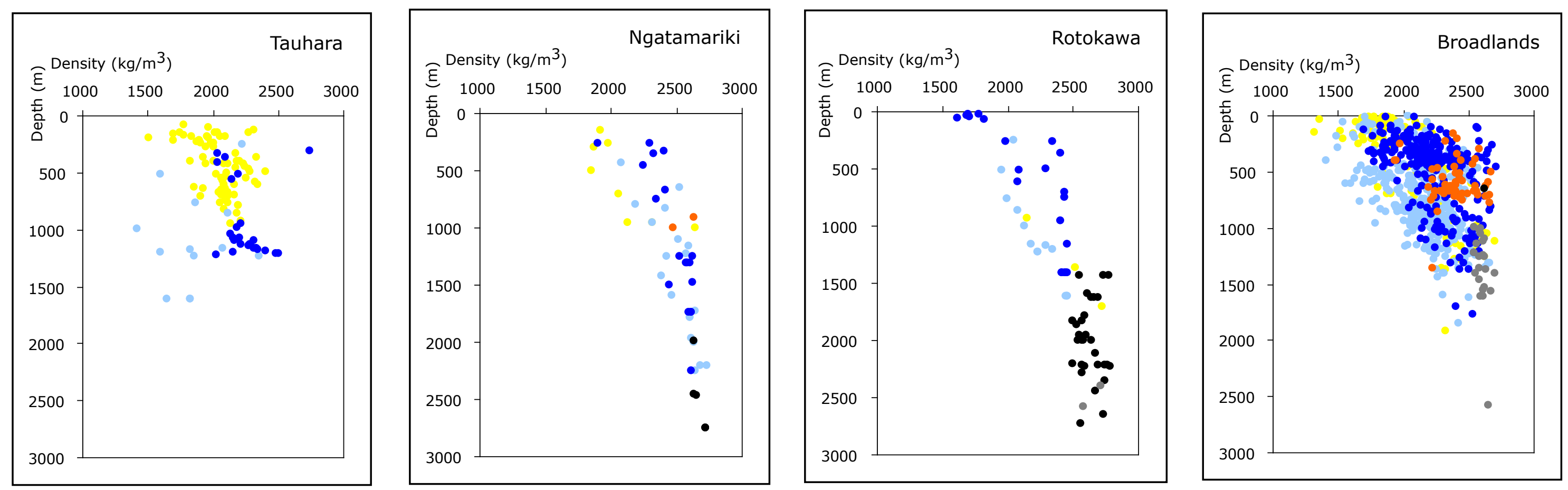

Fig. 2.4. TVZ Geothermal composite drill-hole stratigraphy and density. Density of volcanic materials typically decreases with depth, however individual drill-hole data shows variability due to composition and possible alteration effects (Fig. 6.4 and 6.5) [Stern, 1987]. Rhyolitic compositions dominate the stratigraphy, andesite is intersected above Mesozoic greywacke basement or between rhyolitic material in the Kawerau, Waiotapu, and Wairakei geothermal fields. Andesite forms the basement in the Ngatamariki and Rotokawa geothermal fields adjacent to the eastern boundary of the Whakamaru Caldera. Residual gravity map and the location and extent of TVZ geothermal areas detailed for reference [Bibby et al., 1995; this study]. Data: GNS PETLAB Database. Refer to Table 6.3 for location and collector information. 


\subsubsection{D Gravity modelling}

Simple one and two-dimensional gravity models can be used to estimate the minimum depth to basement [e.g. Cordell, 1973; Rogan, 1982; Fergusson et al., 1994; Stagpoole, 1994; Davy \& Caldwell, 1998]. One dimensional gravity models, where constrained, provide a smoothed first-order depth estimate to basement for each gravity station (Fig. 5). These types of models however provide little information on possible subsurface structure. Two and a half-dimensional gravity models can estimate subsurface structure but are poorly constrained in the region due to the lack of subsurface density information. These types of models can over or under estimate basement depth and exaggerate subsurface structure (e.g. Rogan (1982) estimated 5 km of subsidence associated with the caldera using a single layer 2D model). By using both types of gravity model in tandem a more robust geometry for the caldera can be established than would be possible using the models in isolation.

Following on from the gravity work of Rogan [1982] and Stern [1986] within and adjacent to the OVC, a series of models have been calculated using the exponentially decreasing density contrast $\Delta \rho(\mathrm{z})$ with depth of Cordell [1973]:

$$
\Delta \rho(\mathrm{z})=\Delta \rho_{0} e^{-\lambda \mathrm{z}}
$$

Here $\mathrm{z}$ is positive vertically downward in kilometres, $\lambda$ represents the compressibility of the rock in reciprocal length units, and $\Delta \rho_{0}$ represents the density contrast between the basin infill at the surface and the basement. This expression was developed for the investigation of sedimentary basins where progressive sediment compaction is approximated by a continuous, exponentially decreasing function of depth ( $\lambda$ ranging from 0.28 to $1.46 \mathrm{~km}^{-1}$ ) [Cordell, 1973]. Cordell [1973] observed that the residual gravity effect of a Bouguer slab with decreasing density contrast with depth tends to a finite limit, placing a limitation on the resolution of the depth estimate over deep structures.

Three model density contrasts were considered for the range of TVZ surface densities. Two end members and an intermediate $\left(800 \mathrm{~kg} / \mathrm{m}^{3}, 550 \mathrm{~kg} / \mathrm{m}^{3}\right.$, and $670 \mathrm{~kg} / \mathrm{m}^{3}$ respectively) were based on previous gravity studies and analysis of TVZ rock density data (Table 2.1). A range of exponential decrements between 0.3 and $0.8 \mathrm{~km}^{-1}$ were used to calculate theoretical density contrasts at depth increments of $100 \mathrm{~m}$ from each initial density contrast to a total depth of $5 \mathrm{~km}$ (Fig. 2.5). A cumulative 1-D model gravity anomaly, assuming an infinite Bouguer plate configuration, is calculated using a basement density of $2670 \mathrm{~kg} / \mathrm{m}^{3}$ defined by: 


$$
\Delta \mathrm{g}=2 \pi \mathrm{G} \sum_{\mathrm{i}-1}^{\mathrm{N}}\left(\mathrm{h}_{\mathrm{i}}-\mathrm{h}_{\mathrm{i}-1}\right)\left(\rho_{\mathrm{i}}-2670\right) \quad \text { after Stern [1986] }
$$

Here $G$ is the Gravitational constant, $\rho_{i}$ and $h_{i}$ are the density $\left(\mathrm{kg} / \mathrm{m}^{3}\right)$ and depth of the ith sample respectively, $\mathrm{N}$ is the number of samples and $\mathrm{h}_{0}$ is the ground surface. A series of curves for different values of $\lambda$ can then be produced for each of the surface density contrasts. An independent set of constraints (e.g. published drill-hole, seismic refraction, reflection, and tomographic data along with preliminary magnetotelluric models) to basement depth is then used to select the most appropriate curve for each initial density contrast (Fig. 2.5, Table 6.2).

An initial surface density contrast of $670 \mathrm{~kg} / \mathrm{m}^{3}$ with $\lambda=0.4 \mathrm{~km}^{-1}$ provided the best-fit (least squares) to the independent constraints and is consistent with TVZ surface rock density data (Table 2.1). A third order polynomial fitted to the curve provides a residual gravity verses depth to basement (Fig. 6.8):

$$
\mathrm{z}_{\mathrm{b}}=-0.0244(\Delta \mathrm{g})^{3}-0.9663(\Delta \mathrm{g})^{2}-53.238(\Delta \mathrm{g})
$$

Here $\mathrm{z}_{\mathrm{b}}$ is depth in meters to basement and $\Delta \mathrm{g}$ is the observed residual gravity anomaly. This gravity model has a typical TVZ surface density contrast relative to basement, predicts the residual gravity anomaly of the nearest subsurface density data to the OVC to a depth of $1 \mathrm{~km}$ (i.e. Kawerau geothermal drillholes in Fig. 2), and is consistent with depths to basement derived from Vp tomography (i.e. transition from 4 to $5 \mathrm{~km} / \mathrm{s}$ ) and magnetotelluric studies in the Okataina region (e.g. 2-4 km) (Sherburn et al., 2003; Bibby et al., 2008).

\subsubsection{1/2D Gravity modelling}

Two and half dimension gravity models (i.e. cross sections with an out of plane dimension) with a two-layer density structure (developed using ENCOM Modelvision pro) were constructed using two-dimensional bodies (with infinite strike length) representing surface volcanic rocks and simplistic three dimensional shapes representing deeper volcanic rocks. The topography along each profile was obtained from the altitude at each gravity station. A simplified density structure is used here for $2 \frac{1}{2} \mathrm{D}$ gravity modelling as a uniform density contrast is sufficient to model the only reliable subsurface basement depth available (e.g. Kawerau geothermal drill-holes average depth $\sim 1000 \mathrm{~m}$ ). Rock densities used here are consistent with previous gravity models of the TVZ [Modriniak \& Studt, 1959; Rogan, 1982; Stern, 1986; Stagpoole, 1994]. These were $2670 \mathrm{~kg} / \mathrm{m}^{3}$ for basement, $2350 \mathrm{~kg} / \mathrm{m}^{3}$ for older volcanic rocks, $2200 \mathrm{~kg} / \mathrm{m}^{3}$ for rhyolitic dome complexes, and $2150 \mathrm{~kg} / \mathrm{m}^{3}$ for near surface volcanic material (Ignimbrite and tuff). 


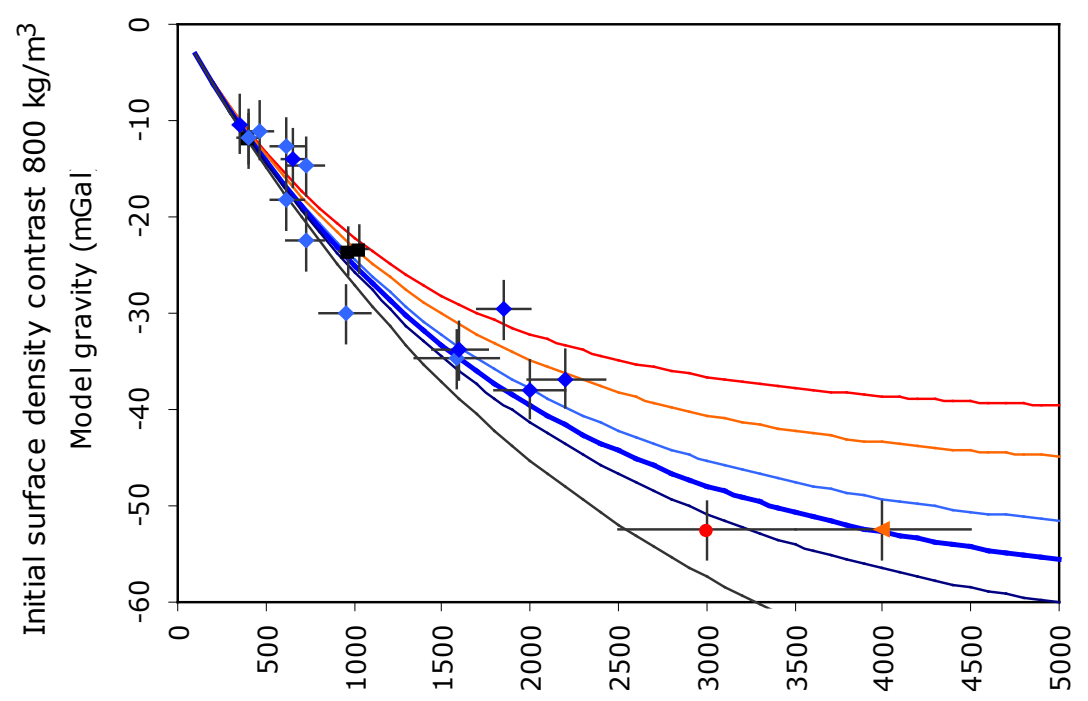

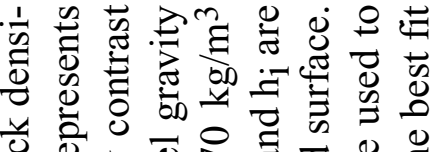
는 它 ए व 0 जी

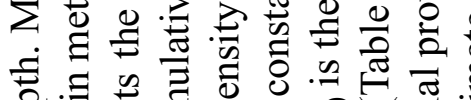

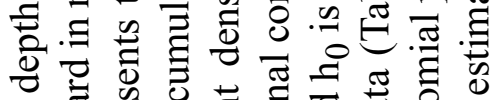

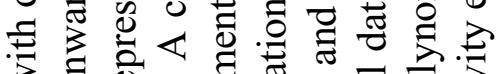

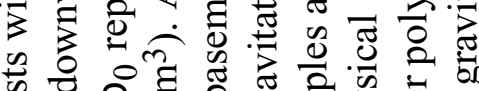

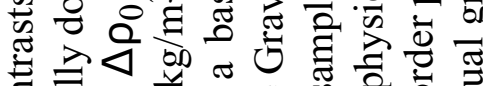

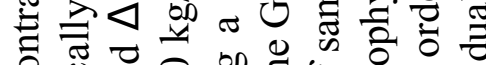
(u) $47 \mathrm{~d}$ वa

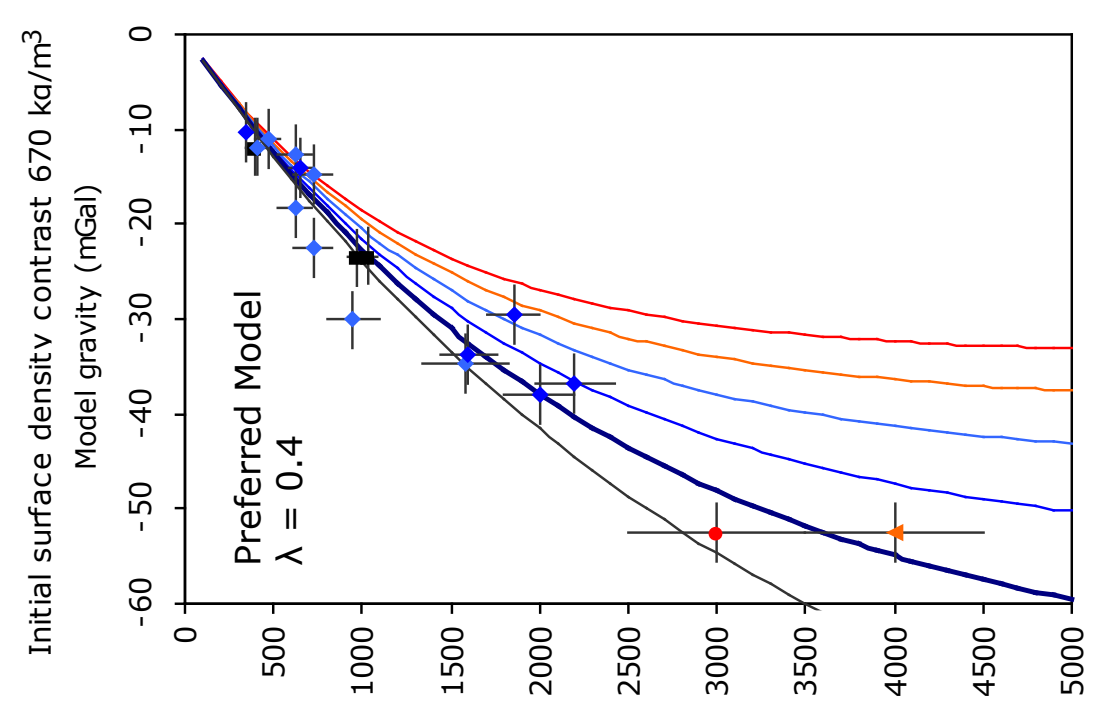

(w) प?də0 尝氙 के

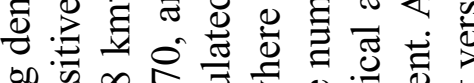

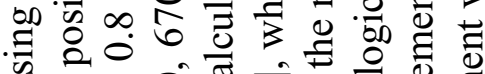
:

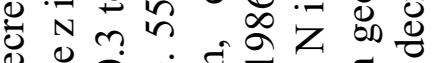
ச

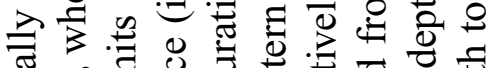

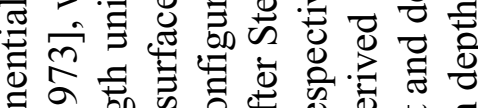

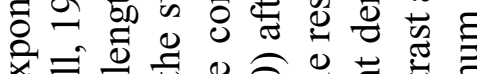

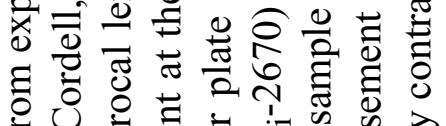

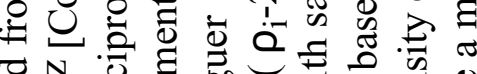

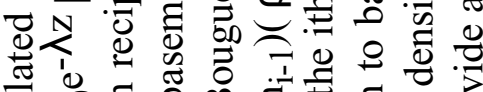

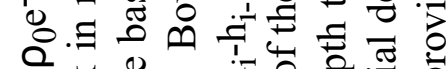
过过出导.

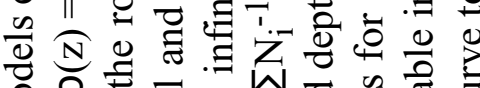

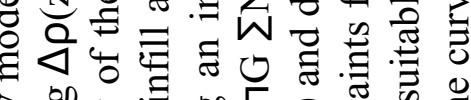
己.

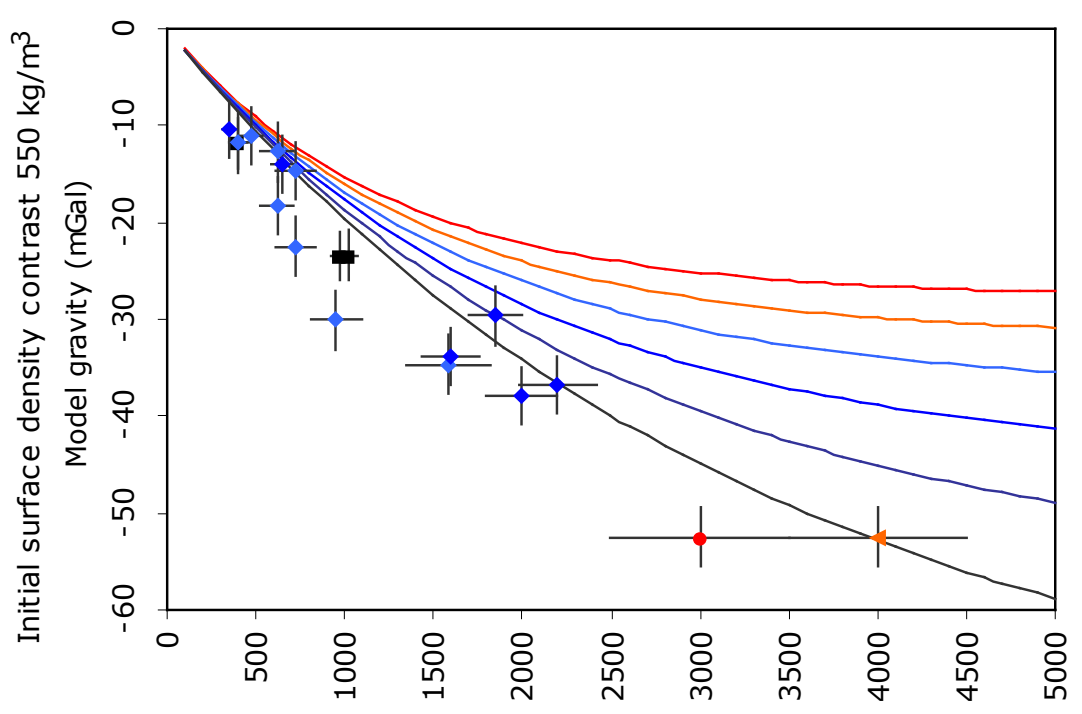

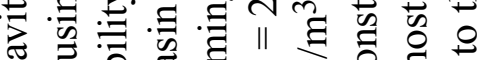

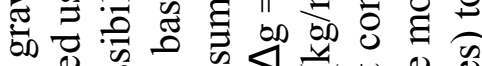

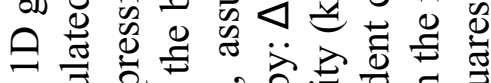

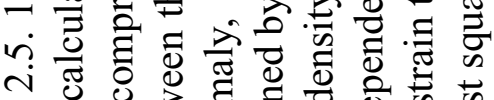

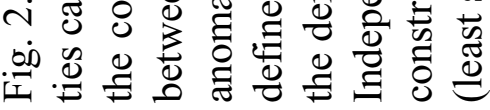

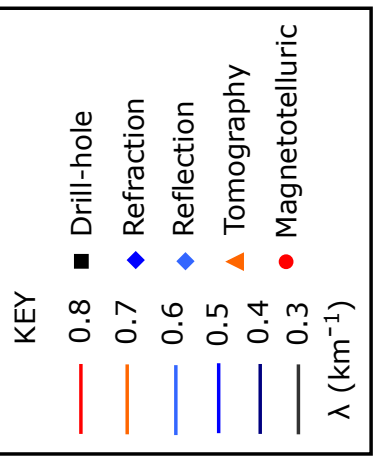


Previous gravity studies of the OVC had estimated up to $5 \mathrm{~km}$ of subsidence associated with the caldera [Rogan, 1982]. However, the interpretation of a preliminary magnetotelluric model [Bibby unpublished data, 2007] allows the composition, density structure, and depth to caldera floor to be interpreted with greater confidence than using the gravity model alone. Gravity anomalies associated with caldera structures in the TVZ have long been interpreted as low density volcanoclastic infill of the caldera subsidence structures created during the evacuation of crustal magma chambers [e.g. Wilson et al. 1984; Davy \& Caldwell, 1998]. The preliminary inversion of magnetotelluric data across the Okataina Caldera show conductive and/or porous material to depths of $3 \mathrm{~km}$, underlain by high resistivities (Fig. 2.6) [Bibby pers comm., 2007]. The low resistivities observed to $3 \mathrm{~km}$ depth are interpreted here as conductive material (i.e. volcanoclastic infill) as welded ignimbrite has been intersected at depths of $3.2 \mathrm{~km}$ with very poor permeability in the Mangakino Caldera (-65 mGal) [Spinks et al., 2005] and the porosity of TVZ volcanic products from geothermal drill-holes decreases to near zero at depths greater than $2 \mathrm{~km}$ [Stratford \& Stern, 2008]. These preliminary magnetotelluric data are consistent with the interpretation of low density volcanic material infilling the collapse structure and provide an independent depth estimate for the shape and floor of the caldera.

Non-unique models were developed by interactively altering the shape of bodies, representative of volcanic rocks, to obtain an acceptable fit between the observed and calculated gravity anomalies. Five $2 \frac{1}{2} \mathrm{D}$ gravity profiles with a range of orientations (two of which are shown in Fig. 2.7) were used to determine the first order geometry of the caldera structure. These models all have the same two layer density structure with the caldera floor constrained to a depth of $3 \pm 0.5 \mathrm{~km}$.

\subsubsection{Seismic reflection lines}

In seismic reflection surveys the energy from seismic pulses is reflected from subsurface interfaces and recorded at a near-normal incidence at the surface. The differing physical properties of individual geological layers (e.g. density and porosity) results in an acoustic impedance that reflects a proportion of the seismic energy back to the surface. These raw data are stacked and processed to produce a seismic image of the subsurface structure, which represents, but is fundamentally different from, a depth section of the geology [Kearey et al., 2002]. 
A Preliminary interpretation of 2D magnetotelluric model [Bibby unpublished data, 2007]
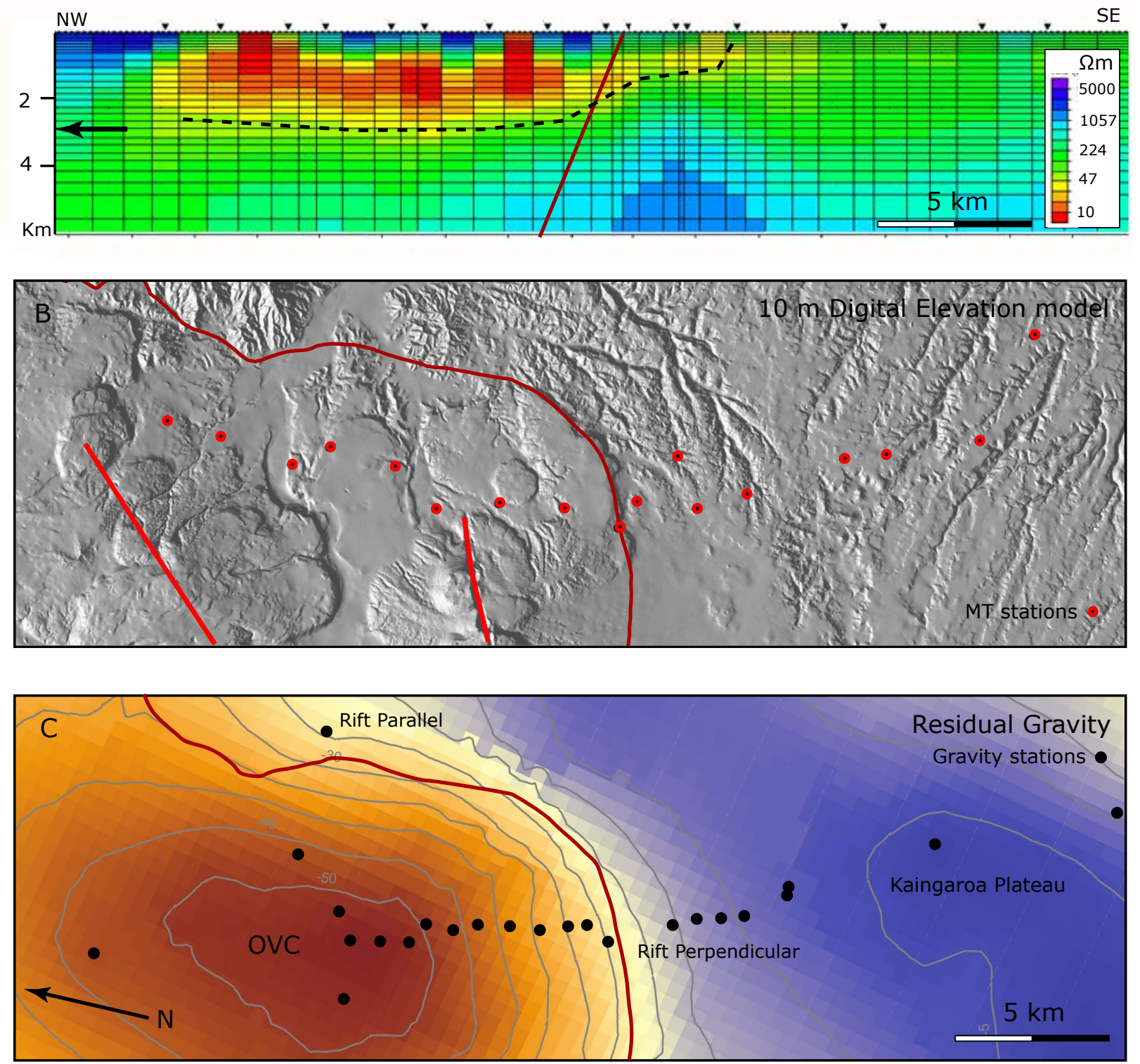

Fig. 2.6. Preliminary interpretation of a magnetotelluric 2D inversion model across the OVC [Bibby unpublished data, 2007]. (A) Resistivity $(\Omega \mathrm{m})$ with depth along northwest-southeast profile perpendicular to the Taupo Rift. Note the rapid change from low to high resistivities $>3$ $\mathrm{km}$ within the caldera margins. High resistivities to the southeast of the OVC are inferred as poorly conductive Mesozoic greywacke basement [Bibby et al., 1995]. (B) DEM map of OVC showing topographic caldera margin (deep red line) [Nairn, 1989, 2002] and MT stations (filled red circles). The linear vent zones of Tarawera and Haroharo (red lines) are shown for reference. (C) Residual gravity anomaly map (refer Fig. 2.3) showing location of rift perpendicular and parallel profiles (black filled circles) of Fig. 2.7 in relation to the MT stations of (B). Map and depth sections spatially correlated and at a 1:1 scale. 

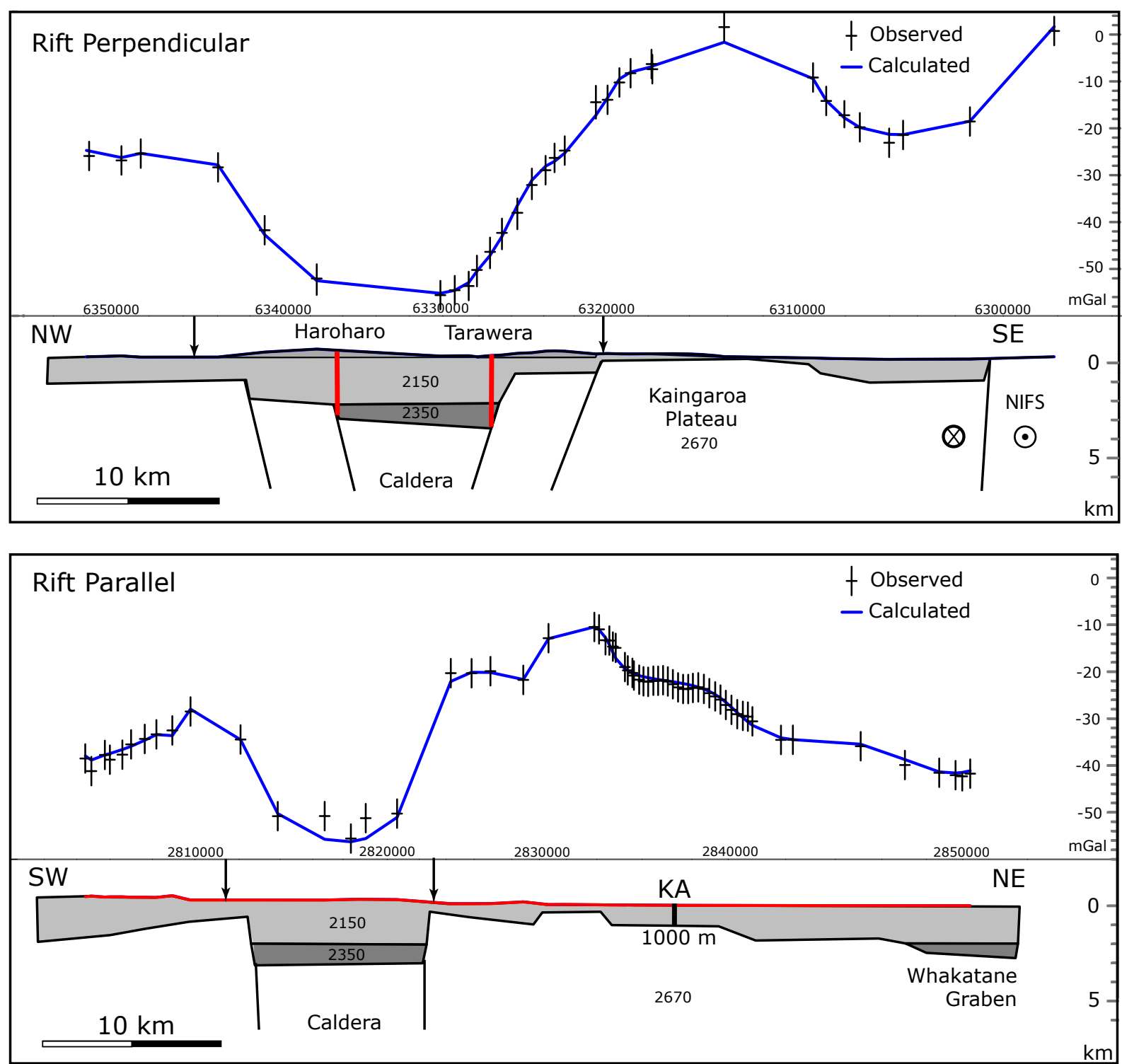

Fig. 2.7. Residual gravity profiles across the OVC. Rift perpendicular and parallel profiles. Low density infill $\left(2150 \mathrm{~kg} / \mathrm{m}^{3}\right)$ modelled as an infinite Bouguer sheet with densities below $2 \mathrm{~km}\left(2350 \mathrm{~kg} / \mathrm{m}^{3}\right)$ modelled as a simple 3-dimensional object (e.g. out of plane $12 \mathrm{~km}$ strike length). Caldera margins consistent with dips of between $55-75^{\circ}$ and $70-90^{\circ}$ in the rift perpendicular and parallel profiles respectively. Arrows denote the topographic caldera boundaries mapped by Nairn [1989, 2002]. The Tarawera linear vent zone (red line) is horizontally constrained to within $\pm 1 \mathrm{~km}$ of caldera margin/floor intersection point, $\sim 3 \mathrm{~km}$ below. The location of the Haroharo

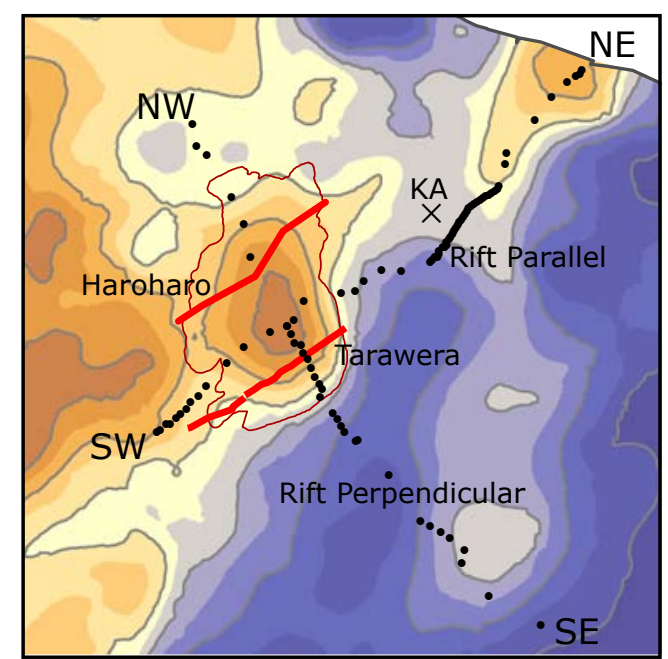
linear vent zone (red line) is less well constrained. Kawerau geothermal drill-hole (KA) shown for reference. Inset map shows the location of the gravity stations used in each profile (black filled circles). Horizontal and vertical scale 1:1. 
One of the key questions that seismic reflection data will help to resolve is whether rift faults terminate against the southwest topographic caldera margin or continue into the caldera complex. Here, seismic reflection data help to delineate faults and caldera structures post-220 ka at depths of up to $~ 900 \mathrm{~m}$ within the OVC. The seismic reflection data have been collected, processed, and interpreted by Davy \& Bibby [2005]. For details of seismic acquisition and processing refer to Davy \& Bibby [2005]. These seismic lines have been reinterpreted at a 1:1000 scale as part of this study and used to map faults beneath Lake Tarawera and into the caldera complex. The seismic reflection survey comprises 6 lines with a total line length of $35 \mathrm{~km}$ (Fig. 2.8). Seismic lines are primarily orientated parallel and perpendicular to the regional strike of faults, with line spacing of 0.8 to $1.8 \mathrm{~km}$ and resolvable reflectors down to a two-way travel time (TWTT) of 1s (800-900 m depth). Seismic lines are sufficiently closely spaced to produce a crude structure contour map of key reflectors and to correlate the larger faults between lines (Fig. 2.8 inset).

Volcanic stratigraphy mapped along the shores of Lake Tarawera has been projected into the seismic lines to estimate the ages of key seismic reflectors [Nairn, 2002]. A 50 ms thick package of strong, sub-parallel reflectors (termed ' $M$ ' horizon by Davy \& Bibby [2005]) coherent across all available seismic lines is inferred as the top of the Mamaku Ignimbrite (Fig. 2.9). The principal constraint for the top of the $220 \mathrm{ka}$ Mamaku Ignimbrite is the projection of this surface from the northern margin of Lake Tarawera (E2807145 N6331235) to Moura Point (E2810415 N6325030) [Nairn, 1989]. Post-60 ka volcanic stratigraphy is inferred to correspond with the package of strong laminated reflectors within $100 \mathrm{~ms}$ of the lake bed (Fig. 2.9). The thickness of the inferred post 60 ka sequence is consistent with mapped volcanic rocks onshore [Nairn, 2002]. While the age of seismic reflectors adopted in this thesis are consistent with those of Davy \& Bibby [2005], they should be considered first order estimates only.

Truncation and offset of continuous reflectors indicate the location, geometry, and displacement of faults within the topographic margin of the caldera. The presence of faults inferred from the seismic lines is consistent with the locations and geometries of faults mapped along the lake shore and in swath bathymetry of the lake floor (e.g. Fig. 2.9b) [Nairn, 1989; Davy unpublished data, 2007]. Several of these faults are considered the continuation of onshore faults associated with the Whirinaki Fault zone [Nairn, 1989]. 


\subsubsection{Topographic Analysis}

The analysis of topography through the use of aerial photographs and digital elevation models (DEM) is an important source of data for faults and volcanic features (e.g. rhyolitic domes) exposed at the ground surface. Topographic analysis principally provides detailed information on the locations, lengths, and displacements of normal faults along with general information on the topographic margin of the caldera.

Active normal faults within the Taupo Rift form scarps that record displacements of topographic surfaces formed by fluvial and aggradation processes, volcanic flow and fall deposits, and volcanic domes. The fault origin of the scarps has been confirmed by trenching and examination of road cut exposures [e.g. Villamor \& Berryman, 2001, Berryman et al. in review; this study]. Scarps forming active fault traces have been mapped across the study area towards the topographic caldera margin using orthorectified aerial photographs at 1:17 000 scale (Fig. 2.8). Aerial photographs typically resolve fault trace scarps higher than ca. 1-1.5 m and longer than $200 \mathrm{~m}$. Scarps record the location, vertical displacement and throw direction of faults. Analysis of individual fault traces using a high resolution TOPSAR DEM permits measurement of vertical displacements (Chapter 3).

Faults recorded in the topography are biased towards those areas were volcanic and fluvial surfaces have not been significantly modified by erosion or burial. The importance of erosion and burial of topographic surfaces increases with surface age, and may partly account for a reduction in the density of faulting on older surfaces. Across older surfaces (i.e. ages $>100 \mathrm{kyr}$ ) faults with throws $<10 \mathrm{~m}$ are rarely resolved in the topography. The density of resolvable normal fault traces also declines in areas adjacent to recent volcanic activity. For example, the area immediately adjacent to Lake Rotomahana (and the termination of $1886 \mathrm{AD}$ basaltic dike) has been covered by basal surge (up to $10 \mathrm{~m}$ thick) deposits from phreato-magmatic explosions associated with the 1886 AD Tarawera eruption. Therefore, the apparent reduction in the numbers of faults in the region of thick $1886 \mathrm{AD}$ eruption deposits is, in part, due to the inability to detect faults buried by volcanic materials. 


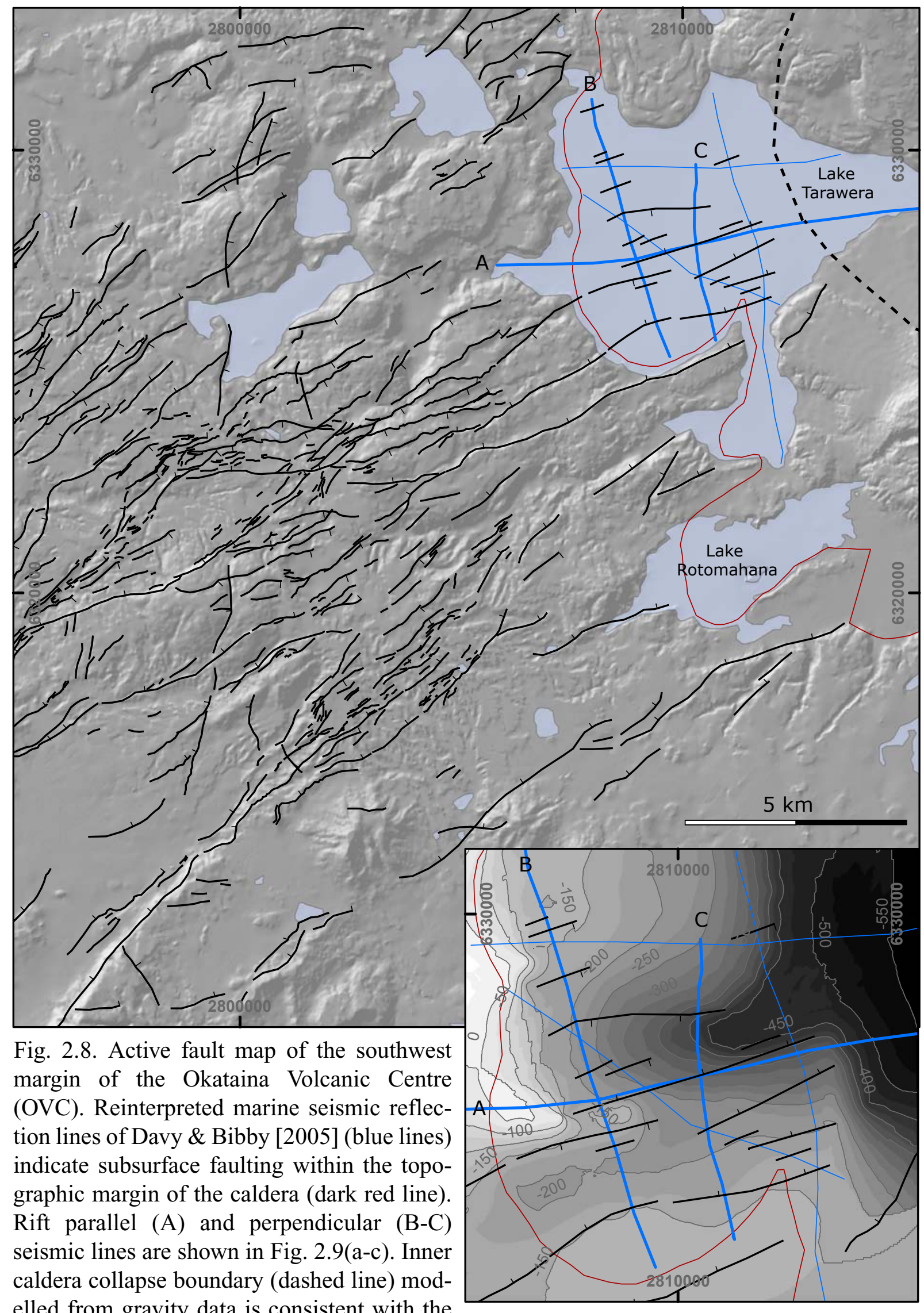

elled from gravity data is consistent with the collapse boundary identified in Fig. 2.9a from seismic reflection line A. Inset: Structural contour map of the ' $\mathrm{M}$ ' horizon across Lake Tarawera. Contours in metres below lake level. Note the re-entrant extending from collapse boundary and partially bounded by faults. 


\subsection{Continuity of faults through the caldera complex}

Mapping of fault traces at the ground surface suggests that they decrease in density from southwest to northeast as they enter the caldera complex (Fig. 2.8). It is important to resolve whether this apparent fault density decrease arises because fault displacements diminish into the caldera and/or because they become progressively buried by volcanic deposits from the volcanic complex. If the decrease of faulting within the caldera is due to sampling bias, then faulting may influence the geometry of the caldera while continuing to accommodate some crustal extension in the volcanic complex. Alternatively, if faults are absent from the volcanic complex, then volcanism may accommodate crustal extension (e.g. via dike emplacement) and will not be influenced by active faulting.

Topographic and geologic mapping enables some of the larger faults $(>30 \mathrm{~m}$ throw) to be traced to the shores of Lake Tarawera. Seismic reflection lines (A-C) (Fig 2.9a-c) in Lake Tarawera indicate the presence of many normal faults beneath the lake and within the topographic margin of the caldera. Sub-lake faults, some of which have been correlated with onshore faults southwest of the lake (Fig. 2.8), appear to form a central graben which bounds a zone of subsidence highlighted by the geometry of the ' $M$ ' horizon in Fig. 2.8 inset map. The faults beneath Lake Tarawera, including the central graben, are interpreted to represent the northeast continuation of the rift into the caldera complex. No seismic reflection lines have been collected normal to the rift and east of the inner caldera margin (dashed line main map) in Fig. 2.8 and, using seismic reflection lines, it is not possible to determine whether rift faults also pass into the inner collapse structure.

The presence of faults beneath Lake Tarawera is consistent with the view that at least some extension in the OVC is accommodated by faulting. The increase in the density of faults from the southwest shores extending to beneath the lake suggests that the relatively low number of resolvable faults immediately southwest of Lake Tarawera occurs because some of the faults have been buried by volcanic eruptive deposits. Based on the available fault mapping the possibility remains that the density of faults does not change across the southwest margin of the OVC. 

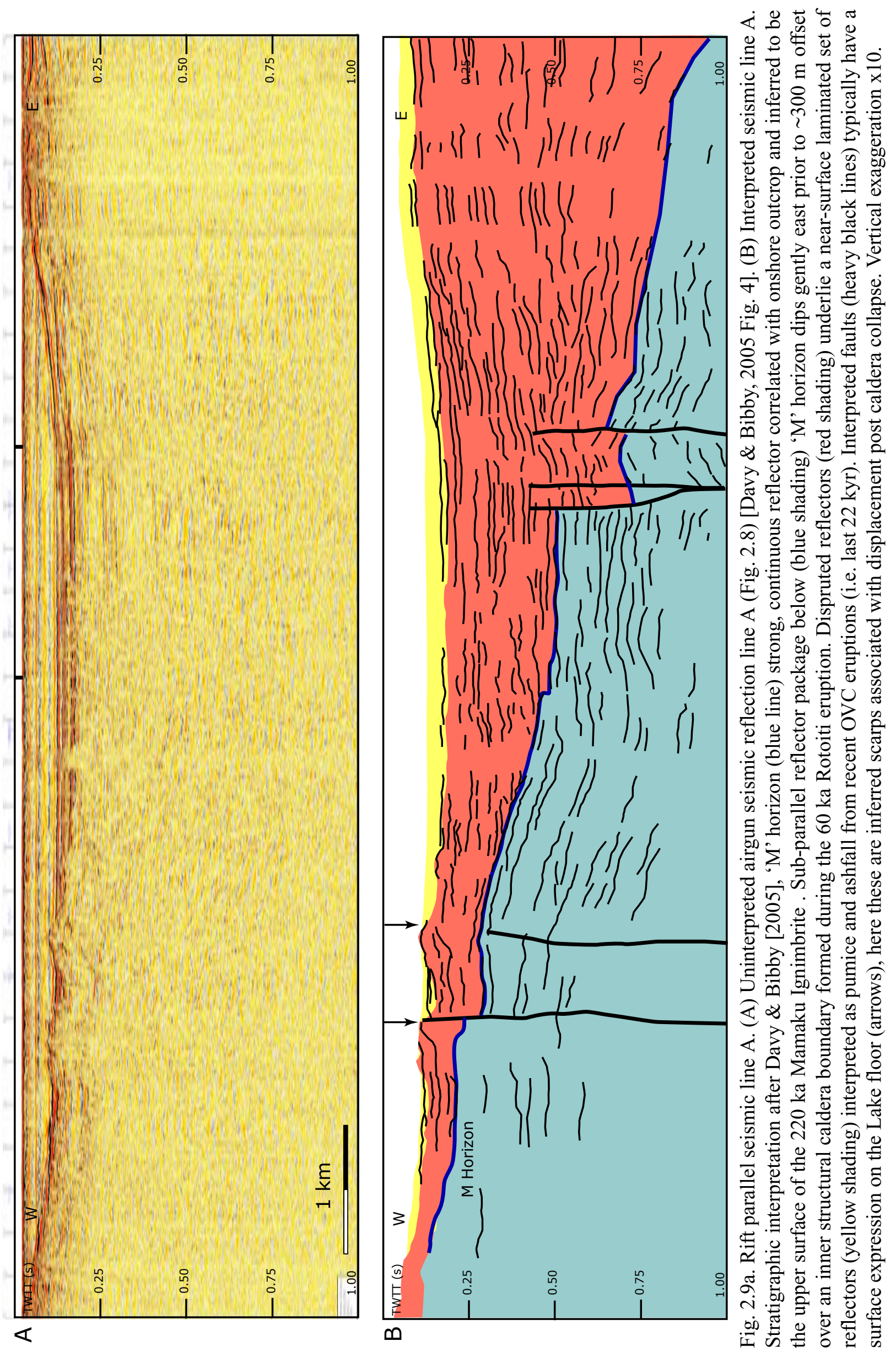

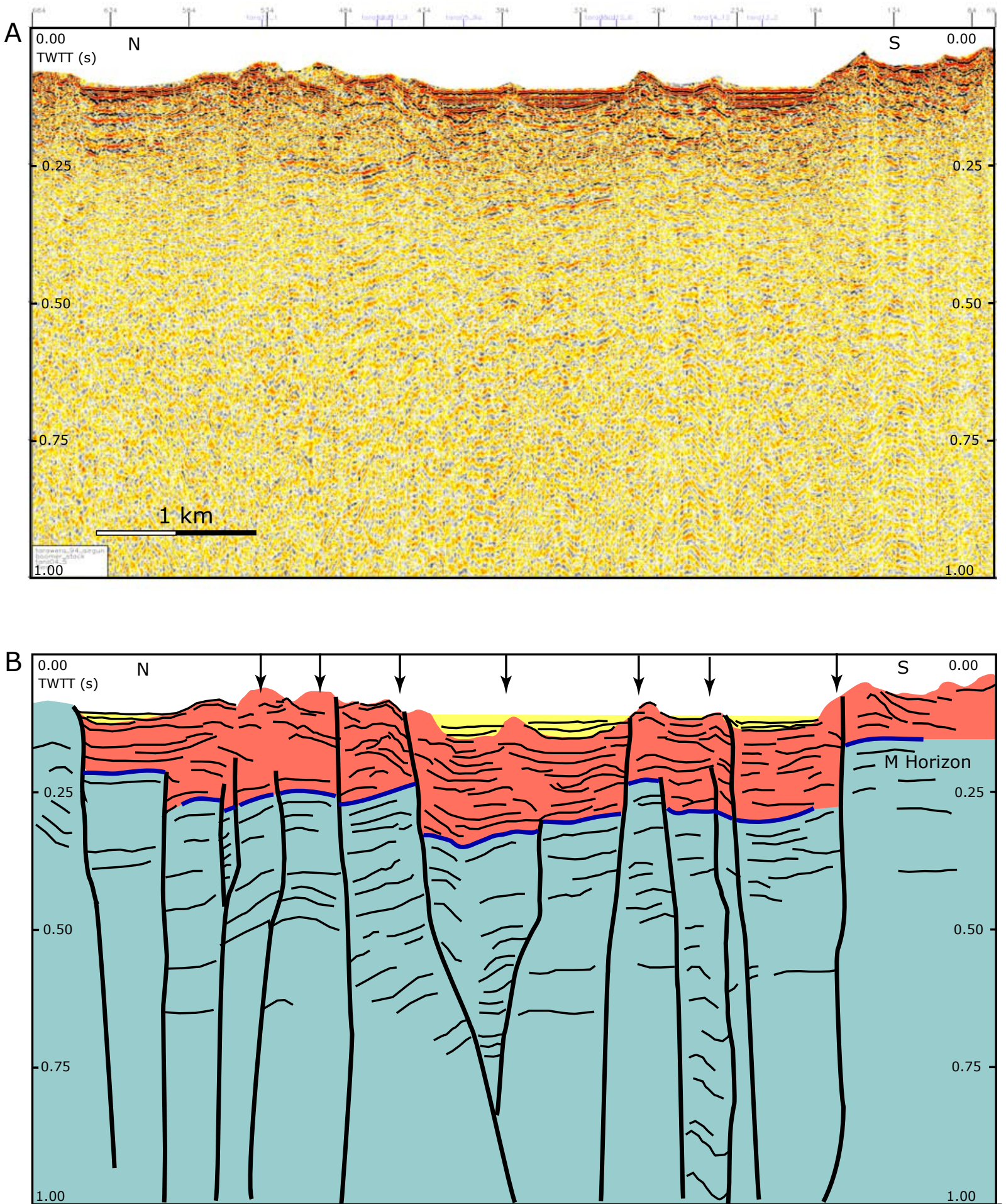

Fig. 2.9b. Rift perpendicular seismic reflection line B. (A) Uninterpreted airgun seismic reflection line C. (B) Interpreted seismic reflection line $\mathrm{C}$ (refer to description of units in Fig. 2.9a). Normal block faulting with a central graben $<4 \mathrm{~km}$ from the inner collapse boundary interpreted in Fig. 2.9a and Davy \& Bibby [2005] (Fig. 4). Fault spacing $(<500 \mathrm{~m})$ similar to faults mapped onshore to the southwest of OVC. Projection of main graben bounding faults northeast to seismic line C (Fig. 2.9c) forms a re-entrant in 'M' horizon (e.g. Fig. 2.8 inset). Vertical exaggeration $\mathrm{x} 6$. 
A

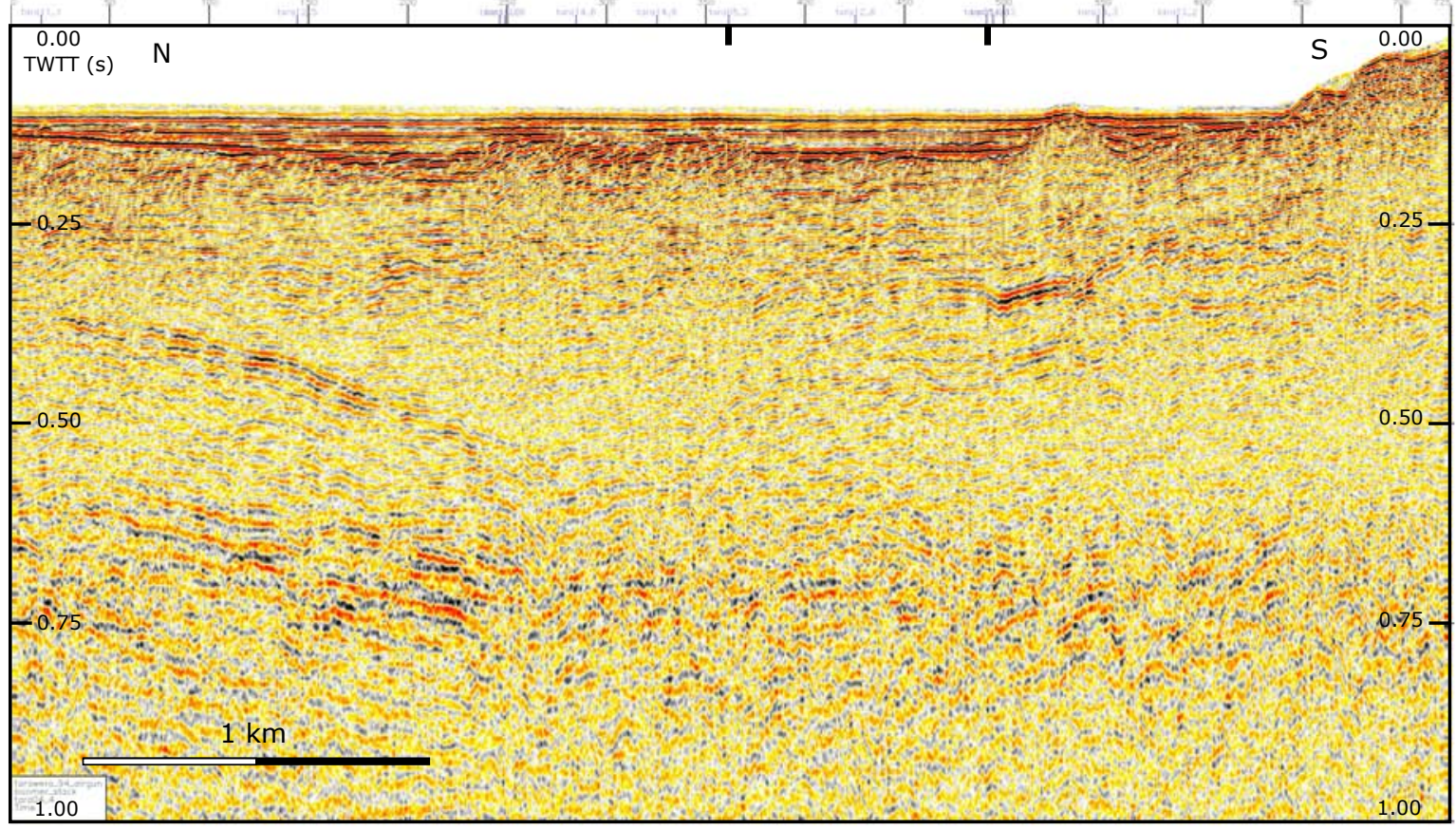

B

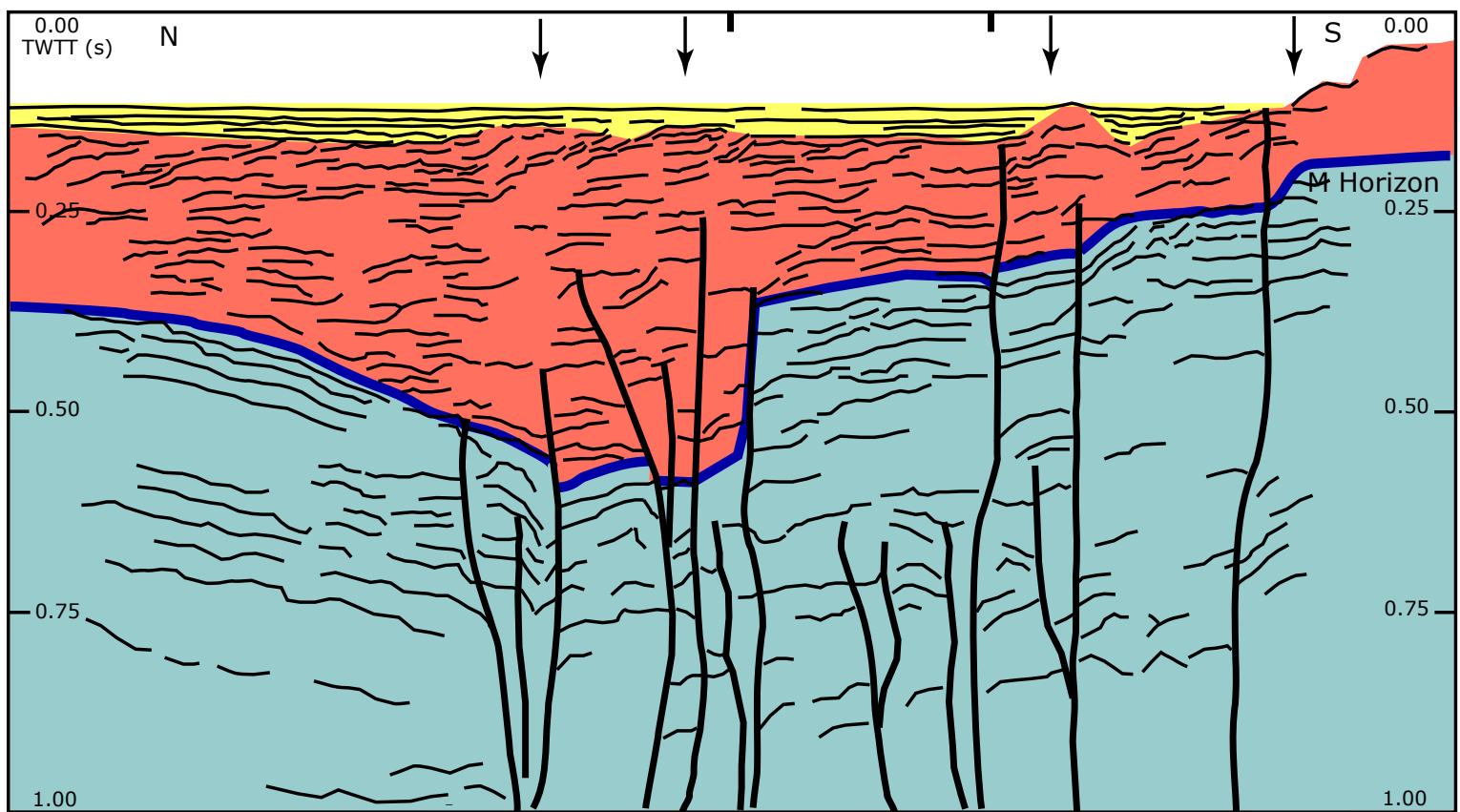

Fig. 2.9c. Rift perpendicular seismic reflection line C. (A) Uninterpreted airgun seismic reflection line C (Fig. 2.8) [Davy \& Bibby, 2005 Fig. 6]. (B) Interpreted seismic reflection line C (refer to description of units in Fig. 2.9a). Asymmetric subsidence of ' $M$ ' horizon on northwest dipping structure $<2.5 \mathrm{~km}$ from the inner collapse boundary interpreted in Fig. 2.9a and Davy \& Bibby [2005] (Fig. 4). Contrast the displacement style to the systematic block faulting inferred in Fig. 2.9b. Vertical exaggeration $\mathrm{x} 4$. 


\subsubsection{Geometry of Okataina Caldera}

The margins of the Okataina Caldera are well defined by the residual gravity anomaly map (Fig. 2.3). The residual gravity anomaly map exhibits an elongate negative residual anomaly within the topographic margin of the Okataina Caldera [Nairn, 1989, 2002]. Both the gravity anomaly and the topographic margin of the caldera are elongate in an approximately north-south direction (long axis $175 \pm 5^{\circ}$ eccentricity $\mathrm{E}=\mathrm{L}_{\min } / \mathrm{L}_{\max }=0.61$ ). The shape and magnitude of the residual gravity anomaly is comparable to that produced using the data of Rogan [1980] recalculated with the regional gravity model of Stern [1979] (Fig. 6.1). The minimum -50 mGal residual gravity anomaly, which is smaller in amplitude than the minimum anomalies associated with the Mangakino and Taupo caldera complexes (i.e. both -65 mGal), is located along strike of the Taupo Rift axis, and bounded by the Tarawera and Haroharo linear vent zones to the northwest and southeast [Stagpoole \& Bibby, 1999; Nairn, 2002]. Within the OVC, residual gravity gradients in a rift parallel orientation (northeast-southwest) across the maximum low are steep (-4.4 \pm 0.4 to $-15.8 \pm 0.5 \mathrm{mGal} / \mathrm{km}$ ), while rift perpendicular (northwest-southeast) residual gravity gradients are shallower ( $-2.0 \pm 0.5$ to $-4.7 \pm 0.5 \mathrm{mGal} / \mathrm{km}$ ) (Fig. 6.2).

Multiple $2 \frac{1}{2} \mathrm{D}$ gravity profiles at differing orientations across the volcanic centre enable an inner collapse structure to be defined (Fig. 6.2), which is distinct from the mapped topographic margin, and similar in geometry to the inner ring fault of Nairn [1989]. This inner collapse structure is approximated by the elongate $-45 \mathrm{mGal}$ gravity contour and delineates the location of maximum subsidence associated with caldera collapse. This interpretation is consistent with the seismic reflection lines of Davy \& Bibby [2005] who define an inner collapse structure associated with the eruption of 100 $\mathrm{km}^{3}$ of ignimbrite during the 60 ka Rotoiti eruption (Fig. 2.9a) [Nairn, 2002].

A gravity profile perpendicular to the Taupo Rift is consistent with a 55-75 dipping southeast primary caldera margin across which top basement steps down approximately $3 \mathrm{~km}$ to the northwest (Fig. 2.7). A second step to the south-east of the main interpreted caldera margin bounds the Kaingaroa Plateau and is consistent with the southern topographic caldera boundary (marked by the arrow in Fig. 2.7) and supported by preliminary magnetotelluric data [Bibby unpublished data, 2007]. The intersection of the caldera floor with the southeast caldera margin is $\sim 3.5 \mathrm{~km}$ vertically beneath the Tarawera Volcanic Complex [Nairn, 1989, 2002]. The north-western margin of the caldera is less well constrained due to the limited number of data points, however, the decrease in gravity values towards the maximum gravity low occurs at least $4 \mathrm{~km}$ 
southeast of the topographic caldera margin. One interpretation of these data is that the northwest margin steps down to the southeast along two or more collapse structures with a series of vertical displacements of $1 \mathrm{~km}$ or less [e.g. Stagpoole, 1994].

The northwest and southeast caldera margins identified on the rift perpendicular profile coincide with the projected location of the rift faults mapped at the ground surface outside the south-western margin of the caldera (Fig. 2.7). The northwest and southeast margins of the caldera define an asymmetric graben with the largest displacement along the southeast margin. This asymmetric basement geometry is similar to that of the rift north and south of the caldera (Fig. 2.10), with the main collapse structures apparently defined by structures within the rift. The location of the caldera within the rift, the spatial coincidence of the northwest and southeast margins of the caldera with the projected locations of important rift faults, and the inferred $55-75^{\circ}$ dips of the northwest and southeast caldera margins are all consistent with the suggestion that collapse of these northwest and southeast caldera margins occurred along tectonic faults. If correct, this would suggest that tectonic faults extend into, and predate caldera formation at $280 \mathrm{ka}$.

The geometry (i.e. strike and dip) of the east and west margins of the rift appear to be different to those of the northwest and southeast margins. The inner collapse structures in the rift parallel gravity profile (Fig. 2.7) have well constrained locations and are consistent with near vertical faults, ranging in dip from $70-90^{\circ}$, steeper than the southeast and northwest margins of the caldera and rift faults. The east and west margins of the caldera strike north to north-northwest. It is inferred, therefore, that the locations and geometry of the east and west margins of the caldera were not controlled by normal faults which strike parallel to the rift. The north-south trending east and west margins of the caldera are approximately parallel to some faults in the rift and to a zone of seismicity within, and to the north of, the caldera (Fig. 2.2). North-south trending lineations delineated by well located earthquakes are also observed within the Haroharo linear vent zone and north-eastern margin of the caldera [Hurst et al., 2008]. These data indicate the presence of a subtle, but important, north-south structural trend in the region of the OVC. This trend is approximately parallel to the strike of the basement terranes and bedding east and west of the OVC (Fig. 2.2). Thus it is postulated that the orientations and locations of the north to north-northwest striking margins of the caldera have been controlled by Mesozoic basement fabrics (i.e. faults and lithological boundaries) of a similar orientation. 
The geometry of basement beneath the TVZ has been inferred from outcrop to the east and west of the Central Volcanic Region (Fig. 2.2). Outcrop data indicates that basement terranes swing in strike from north-east to north-northwest from the Wellington region to Northland (south to north) [Edbrooke, 2001; Mortimer, 2004; Edbrooke, 2005; Leonard \& Begg, in prep.]. These basement fabrics have been reactivated and utilised by some Tertiary faults which also swing in strike parallel to basement terranes [Nicol et al., 2007]. At the latitude of the OVC, basement terrane boundaries and bedding generally strike north-south and dip steeply (60-90 $)$ east and west. Twenty kilometres east of the OVC basement terrane boundaries and bedding have been reactivated by the active North Island Fault System (NIFS). In a similar manner to the NIFS, it is suggested that both faults within the rift and caldera collapse structures utilised pre-existing planes (or zones) of weakness in the basement [cf. Tomassi \& Vauchez, 2001]. These planes of weakness are parallel to the basement fabrics and, in the OVC, are inferred to strike north-south.

\subsection{Origin of Caldera Geometry}

The data and analysis presented in this chapter provide important constraints on the key factors that control the location and geometry of the Okataina Caldera. A spectrum of different generic models can be found in the literature to account for the geometries of caldera collapse structures (Fig. 2.1). The geometries of the caldera collapse structures are, for example, inferred by Bosworth et al. [2003] to be controlled by the geometry of the magma chamber at depth with preferential elongation of the caldera in the direction of the principal horizontal extension direction $\left(S_{\mathrm{hmin}}\right)$. Acocella et al. [2002] infer the existence of an older structural fabric beneath Ethiopian Rift calderas which, in combination with the active rift faults and the direction of regional horizontal extension, creates a transtensional structure interpreted to facilitate the localization of volcanism and caldera collapse. Alternatively, caldera structures may be dominantly controlled by the rift faults and form in response to both rift parallel and perpendicular collapse [e.g. Fergusson et al., 1994; Moore \& Kokelaar, 1998].The geometries and locations of calderas maybe influenced by a number of different mechanisms [e.g. Cole et al., 2005 and references therein]. This multiple-mechanism theme probably also applies to the Okataina Caldera. 

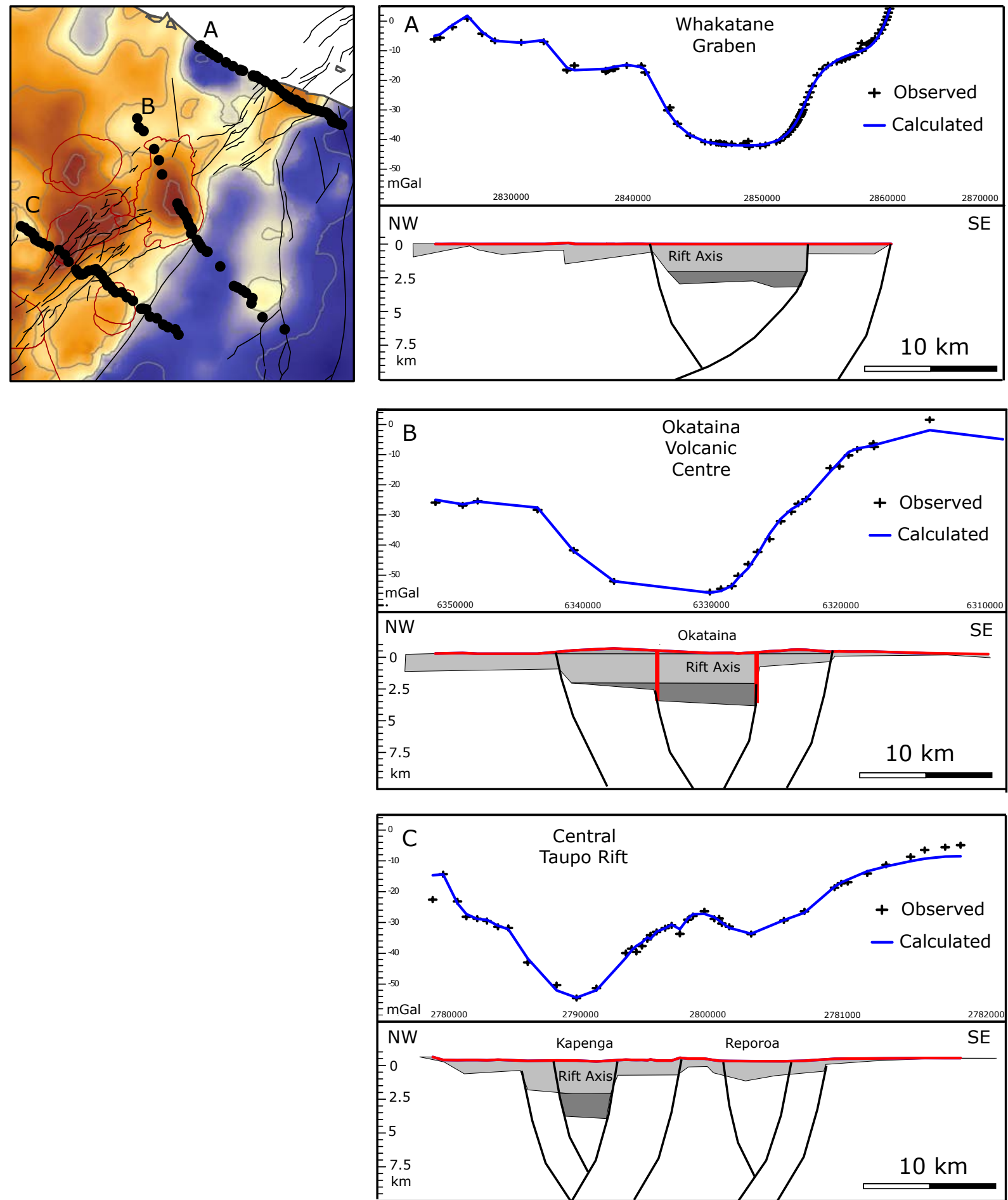

Fig. 2.10. Gravity profiles perpendicular to the Taupo Rift showing the varying fault style and location of subsidence along-strike from north to south. (A) Whakatane Graben, the site of the $1987 \mathrm{M}_{\mathrm{L}} 6.3$ normal faulting Edgecumbe earthquake, interpretation after Nairn \& Beanland [1989], consistent with Lamarche et al. [2006] (B) 500 ka OVC rhyolitic caldera and postcaldera vent locations [Nairn, 1989; Leonard unpublished data, 2007]. (C) Kapenga and Reporoa volcanic centres, $890 \mathrm{ka}$ and $230 \mathrm{ka}$ respectively [Houghton et al., 1995]. Note a dense array of active normal faulting (fault spacing $<500 \mathrm{~m}$ ) occupies the rift axis through the Kapenga Caldera, location of deepest basement. Largest displacements are observed on northwest dipping faults and/or collapse structures. Fault dip angles decrease with depth from $70^{\circ}$ to $55^{\circ}$ unless otherwise constrained. Density structure as in Fig. 2.7. 
The geometry of the caldera appears to have been strongly influenced by a combination of pre-existing rift faults and reactivation of Mesozoic basement fabric. The resulting caldera, which is elongate in an approximately north-south direction, is oblique to the $\sim 150^{\circ}$ orientation of the regional extension direction [Robinson, 1989; Hurst et al., 2002; Beavan et al., 2007] and is unlikely to be strongly influenced by the orientation of strain axes depicted in Fig. 2.1a. The extent to which the geometry of the caldera was influenced by the geometry of the underlying magma chamber cannot be determined at this time. However, as both the basement fabric and rifting predate caldera formation the possibility remains that the geometry of the magma chamber(s) was also influenced by faulting.

Although the faults within the caldera complex may have formed in association with rifting, they appear to have been utilised during caldera collapse. This conclusion is supported by structure contours on the ' $\mathrm{M}$ ' horizon beneath Lake Tarawera (Fig. 2.8 inset). These structure contours, which were constructed from seismic reflection lines, show the presence of a small re-entrant along the southwest margin of the 60 ka inner collapse boundary. The re-entrant appears to be bounded by rift faults. One explanation for the re-entrant is that it formed because the rift faults were preferentially utilised during caldera collapse at $60 \mathrm{ka}$.

\subsection{Caldera collapse style}

The observation of the locus of maximum subsidence for the Okataina Caldera in the south-central region of the topographic caldera margin is consistent with the caldera collapse history proposed by Nairn [2002]. Nairn proposed that the Okataina Caldera formed in response to at least two spatially overlapping collapse events (i.e. at $280 \mathrm{ka}$ and $60 \mathrm{ka}$ ) with the zone of collapse overlapping in the region of maximum subsidence determined by gravity [Wilson et al., 1984; this study].

The collapse style of the caldera appears to vary around the margin of the structure. The simplest interpretation of the caldera collapse geometry in the rift parallel orientation is trapdoor style [cf. Lipman, 1997]. Both piecemeal, and trapdoor caldera collapse geometries can be modelled with gravity perpendicular to the rift [Lipman, 1997]. However, the rift perpendicular gravity profile is best described by asymmetric piecemeal collapse (on several faults) focused along the southeast margin of the caldera [e.g. Nairn, 2002]. 


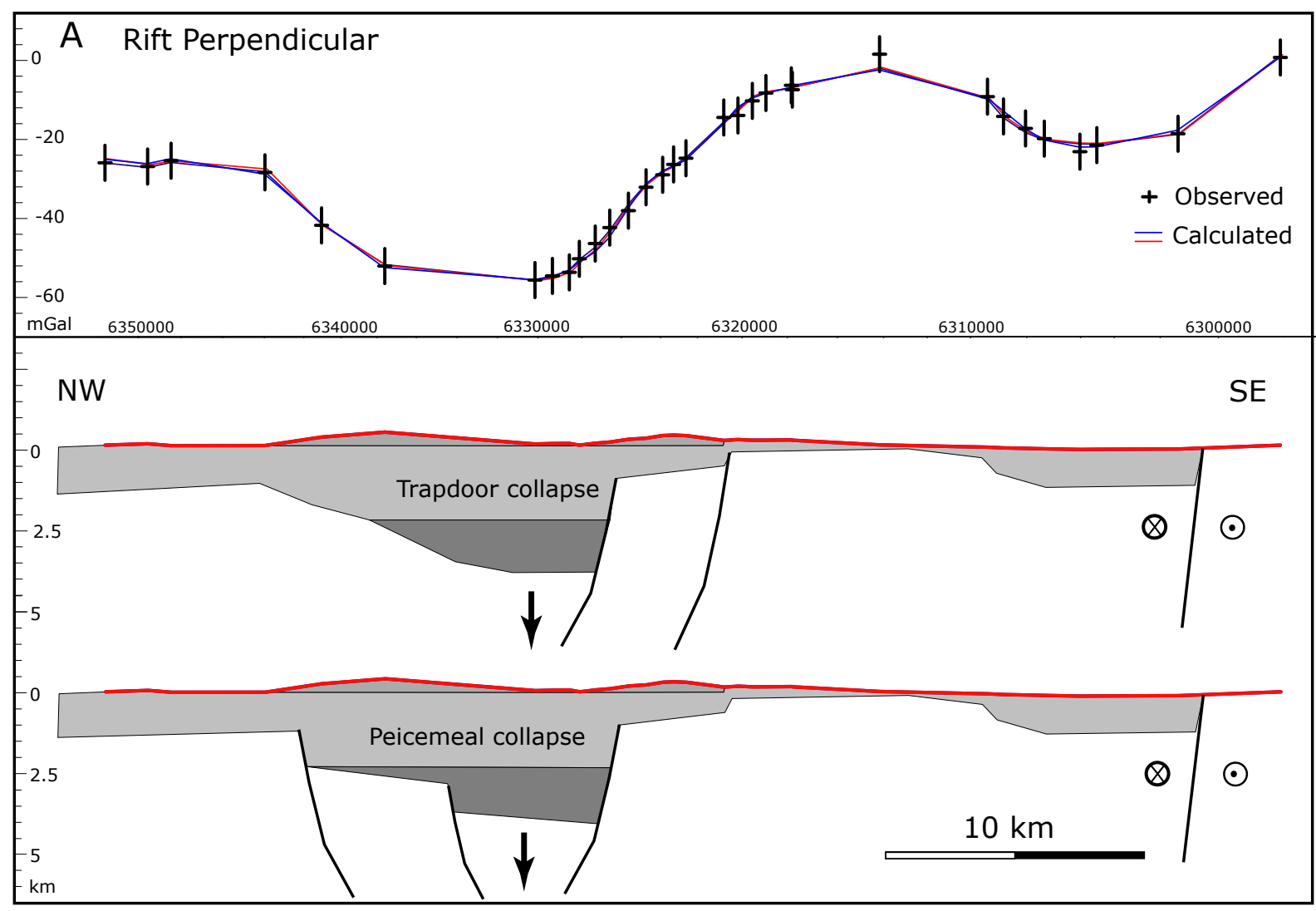

B
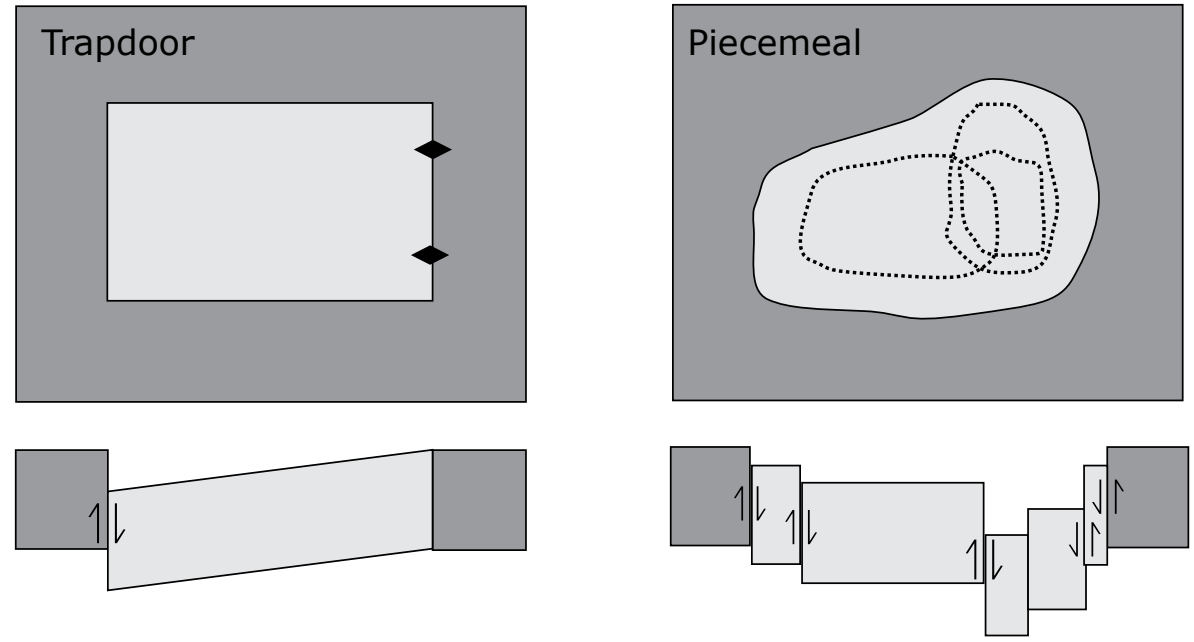

Fig. 2.11. Gravity models of the Okataina Caldera collapse geometry. $2 \frac{1}{2} \mathrm{D}$ gravity models across a rift perpendicular profile (refer to Fig. 2.7 for location and density structure). (A) Two different styles of caldera collapse are modelled (blue and red lines) from the observed data (black crosses) with no significant difference in calculated fit. (B) Schematic diagrams after Cole et al. [2005 and references therein] showing surface expression and cross-section for each collapse style. Differentiation of the collapse style based on gravity is dependent on profile direction, collapse history and tectonic setting. The Okataina Caldera is interpreted as forming in a piecemeal style perpendicular to the Taupo Rift. Collapse in both rift parallel and rift perpendicular orientations has been inferred by Nairn [2002] for the $280 \mathrm{ka}$ Matahina and $60 \mathrm{ka}$ Rotoiti caldera forming events respectively. 
Gravity gradient variations along the caldera margin suggest that the style of collapse is dependent on its orientation with respect to the rift (Fig. 6.2). For example, where the geometry of the caldera is controlled by spatially distributed rift faulting, the collapse style is piecemeal focused primarily on the main tectonic faults. Whatever the caldera collapse model, the minimum depth to the caldera floor derived for this study is consistent with the preliminary magnetotelluric interpretation of Bibby [unpublished data, 2007]. The infill of the caldera subsidence structure by low-velocity, low density volcanic material to depths of $3 \mathrm{~km}$ is consistent with gravity models produced for this investigation.

Any gravity signature associated with a magma chamber at depth is not currently resolvable with the present data. For example, simple gravity modelling of a sphere and cylinder constrained to a top depth of $6 \mathrm{~km}$ beneath the OVC with diameter of $8 \mathrm{~km}$ totalling $\sim 113 \mathrm{~km}^{3}$ (i.e. typical volume for an Okataina ignimbrite eruption) and a density contrast of $-300 \mathrm{~kg} / \mathrm{m}^{3}$ have a gravity contribution of -2.8 and $-3.4 \mathrm{mGal}$ respectively (Fig. 6.6b). The density contrast used here is estimated as a maximum for a partially molten body of rhyolitic composition [e.g. Carle \& Goldstein, 1987] and therefore this contribution to the overall gravity minimum associated with this volcanic centre would be within model error.

\subsection{Discussion}

\subsubsection{Relations between faulting and caldera formation outside the OVC}

The intersection of oblique trending faults in the Okataina region has implications for other caldera complexes within the TVZ, particularly those with north-south elongation (e.g. Mangakino and Whakamaru). Eight sub-circular to elongate rhyolitic TVZ caldera complexes, identified through volcanic mapping, vent location, and residual gravity expression [Wilson et al, 1984; Wilson et al., 1995; Stagpoole \& Bibby, 1999; this study], have variably orientated long axes with respect to the regional extension direction and/or Taupo Rift. Rotorua, Reporoa, and Maroa Calderas are approximately sub-circular, the latter caldera contained within the boundaries of the Taupo Rift [Wilson et al., 1995]. The topographic expression of the Taupo Caldera complex has both a rift parallel and perpendicular collapse geometry [Stagpoole \& Bibby, 1999]. The inner western margin of the Taupo Caldera has however a north-south aligned gravity and magnetic signature [Davy \& Caldwell, 1998]. Residual gravity contours associated 
with the Kapenga Caldera complex are rift and fault parallel (Fig. 4.1) (including a $20^{\circ}$ clockwise rotation in trend from south to north).

The volcanic centres of Okataina, Whakamaru, and Mangakino have caldera long axis elongation in a north-south orientation, oblique to both the regional extension direction $\left(130-150^{\circ}\right)$ and Taupo Rift. The Okataina and Mangakino Calderas have a distinct north-south elongated residual gravity anomaly whereas the Whakamaru volcanic complex has a more complex gravity expression with gravity minimums on the northern and western margins of the mapped structure (e.g. Fig. 2.2) [Wilson et al., 1995; Stagpoole \& Bibby, 1999]. The maximum residual gravity anomaly associated with the Rotorua Caldera is elongate in a north-south direction and appears to have some overlap with the Kapenga caldera complex despite a sub-circular topographic expression (Fig. 2.3).

Gravity data suggest that at least five calderas in the TVZ, including Okataina, have margins which are parallel to the principal rift faults and/or to Mesozoic basement fabric. The Waihi Caldera from the Miocene to Pliocene Coromandel volcanic arc (On the western margin of the Central Volcanic Zone and $90 \mathrm{~km}$ north-northeast of the OVC) also appears to be controlled by northeast-southwest and north-south striking regional faults dipping $\sim 70^{\circ}$ [Smith et al., 2006]. It is suggested that faults throughout the TVZ, which pre-date, pass into and across calderas, are commonly utilised in the collapse process during large ignimbrite eruptions and can therefore have an important control on caldera geometry in the TVZ.

\subsubsection{Calderas and rift fault geometries}

The location of calderas appears to influence the density of active faults observed at the ground surface within the rift. Where basement is near to the ground surface (e.g. $<1$ $\mathrm{km}$ ) faults accumulate displacement on a single large fault slip surface, whereas areas with a dense array of faulting (i.e. average fault trace spacing of $<500 \mathrm{~m}$ ) are often above basement that is relatively deep and within calderas (> $2 \mathrm{~km}$ ). For example, dense surface faulting (average fault trace spacing $200 \mathrm{~m}$ ) observed $10 \mathrm{~km}$ to the southwest of the OVC in the rift axis (Ngakuru Graben/Kapenga Caldera complex) corresponds to the greatest basement depth in this area (i.e. $\geq 3 \mathrm{~km}$ ) (Fig. 2.3) [Rowland \& Sibson, 2001]. By contrast, no fault traces have been observed between the large displacement Paeroa and Ngapouri faults $\sim 7 \mathrm{~km}$ southwest of Waimangu.

The contrasting residual gravity values between the rift axis in the Kapenga Caldera region and large normal faults to the east (-50 verses $-30 \mathrm{mGal}$ respectively) 
outside the caldera suggests a difference in basement elevations $>2 \mathrm{~km}$. Where dense basement rocks are relatively close to the ground surface they have greater apparent fault spacing than faulting in poorly consolidated volcaniclastic material within a caldera above deep basement. Based on these observations the inference is made that the dense array of faults close to the rift axis in the Ngakuru graben (and above the Kapenga Caldera) area is a near surface phenomena and primarily occurs at depths of less than $2 \mathrm{~km}$. At depths greater than $2 \mathrm{~km}$ the active faults approach basement and, as occurs to the east where the basement is relatively shallow (e.g. $\sim 1 \mathrm{~km})$, it is suggested that displacement is focused on several main fault surfaces. Thus, while the caldera can be influenced by pre-existing faults the calderas can, in turn, influence the spatial distribution of near-surface faulting.

\subsection{Conclusions}

Gravity, seismic reflection, topographic and geological data indicate that active rift faults pass into the Okataina Caldera complex. The caldera, which is elongate in a north-south direction and up to $3 \pm 0.5 \mathrm{~km}$ deep, is confined to the Taupo Rift. Caldera collapse at 280 and 60 ka appears to have utilised pre-existing rift faults. The northwest and southeast boundaries of the main gravity-defined caldera (i.e. below $-45 \mathrm{mGal}$ ) are consistent with dips of $55-75^{\circ}$ and appear to be controlled by the principal rift faults. The east and west margins of the caldera are consistent with near vertical faults $\left(70-90^{\circ}\right)$ and it is postulated that these margins formed by the reactivation of similarly orientated Mesozoic basement fabrics (i.e. bedding, terrane boundaries, and/or faults). The geometry of the Okataina Caldera has been influenced by a combination of rift faulting and reactivation of basement fabrics. 
CHAPTER THREE

IMPACT OF DIKE INTRUSION AND CALDERA COLLAPSE ON ACCUMULATION OF FAULT DISPLACEMENTS IN THE OKATAINA VOLCANIC CENTRE 


\subsection{Introduction}

Normal faults in continental rifts typically exhibit a close spatial relationship with magma emplacement [Mastin \& Pollard, 1988; Rubin \& Pollard, 1988; Parsons \& Thompson, 1993; Korme et al., 1997; Corti et al., 2003; Korme et al., 2004; Wright, 2006]. Both tectonic faults and dike intrusion may accommodate regional extension in continental rifts, however the extent to which their formation is interdependent can be uncertain [e.g. Corti et al., 2003; Zeigler \& Cloetingh, 2004]. Analysing vertical displacements (or fault throws) of faults which pass into, or through, volcanic centres may help constrain the kinematic relations between faulting and volcanism. Vertical displacements, which have been widely utilized to determine the growth, scaling relationships and kinematics of faults in non-volcanic rift systems [e.g. Walsh \& Watterson, 1992; Maerten et al., 1999; Walsh et al., 2002; Kim \& Sanderson, 2005; Nicol et al., 2005], provide constraints on whether dike intrusion and caldera collapse has effected the growth of faults (Fig. 3.1).

This chapter examines the interrelationships between volcanism and faulting over the last $280 \mathrm{ka}$ in, and adjacent to, the Okataina Volcanic Centre (OVC), a multiple collapse caldera complex within continental crust. The wealth of published information on Okataina volcanic rocks [Smith, 1886; Cole, 1970; Nairn \& Cole, 1981; Nairn, 1989, 2002; Leonard et al., 2002; Nairn et al., 2004] together with the exceptional surface expression of faults [e.g. Villamor \& Berryman, 2001; Nicol et al., 2006; this study] mean that the south-western margin of the OVC is an ideal location to examine the interdependence of fault displacement accumulation and volcanic activity. The frequent nature of volcanic eruptions associated with the OVC (e.g. approximately 1 every 3 kyr for last 65 ka [Nairn, 2002]) coupled with the well dated and mapped volcanic stratigraphy of the area, allows the relations between the growth of rift faults, dike intrusion, and collapse of a rhyolitic caldera to be investigated over timescales from 1886 AD to $280 \mathrm{ka}$. 


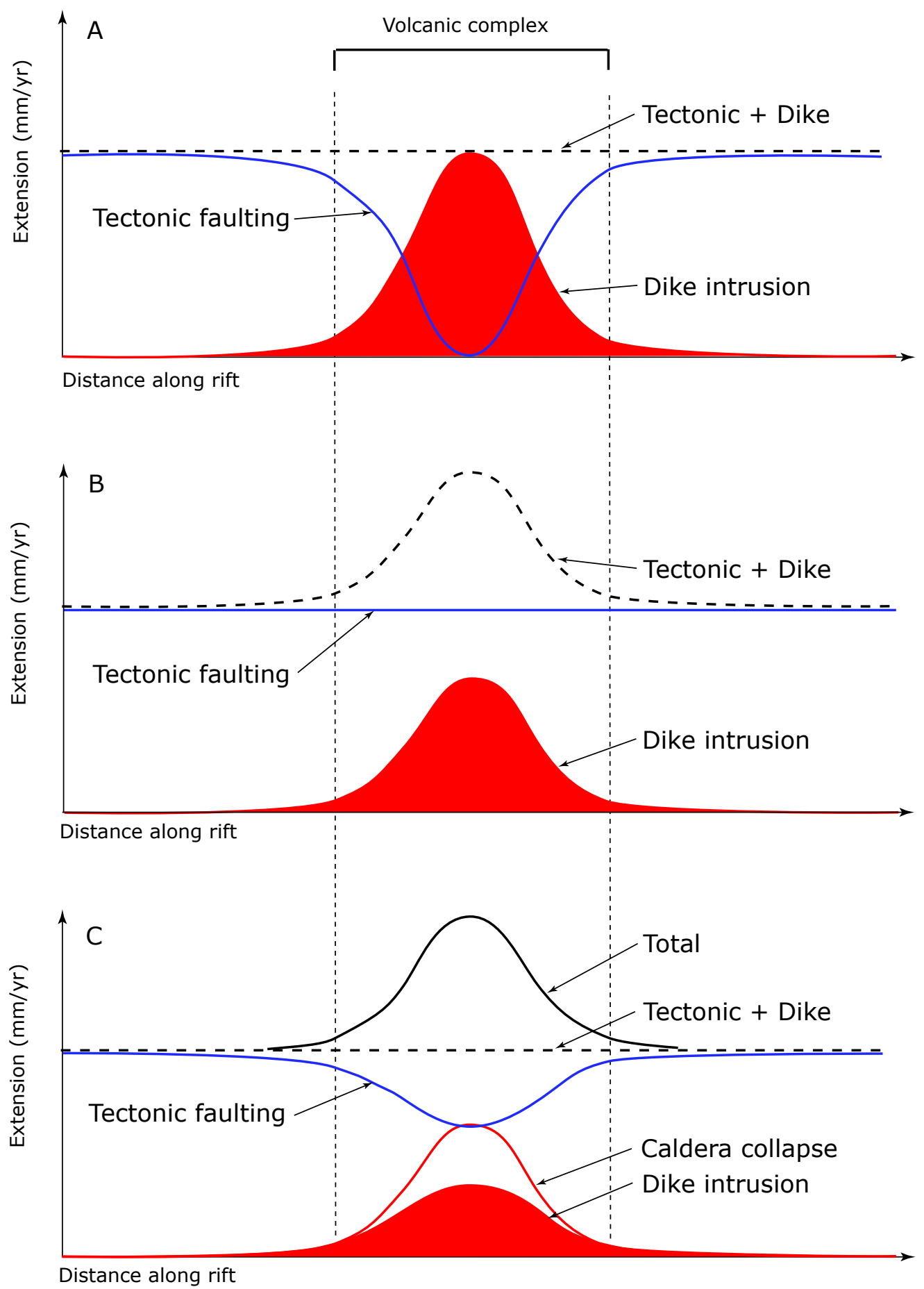

Fig. 3.1. Schematic illustration of three hypothesized end-member relationships between tectonic faults, dike intrusion, and caldera collapse through a volcanic complex. (A) Extension on rift faults (black line) decreases across the boundary of a volcanic complex. Dike intrusion (red shading) increases in proportion to the fault displacement decrease within the caldera complex resulting in uniform displacement along the rift. (B) A local extension maximum across the volcanic complex results from the combination of a uniform fault extension plus additional dike intrusion. (C) Combination of the end-member models in (A) and (B) where the decrease in tectonic fault extension in the volcanic complex is matched by an increase in extension due to dike intrusion. Caldera collapse, which utilises rift faults, increases total extension above uniform background tectonic faulting plus dike intrusion value. (C) Is the preferred model for the OVC. 
Displacements on faults have been measured from digital elevation models, seismic reflection lines and gravity models as they approach, and pass into, the OVC where dike intrusion and caldera collapse have occurred. This use of displacements to examine relations between faults and volcanism differs from many other structural studies of volcanic complexes that primarily focus on characterization of fault kinematics (e.g. fault and slip vector orientations) and the spatial controls that faults exert on volcanism [e.g. Rowland \& Sibson, 2001; Prejean et al., 2002; Acocella et al., 2002 \& 2003]. This chapter chiefly focuses on whether; i) the location, geometry and kinematics of normal faults influenced volcanism, ii) caldera collapse and dike intrusion enhanced fault displacements, and iii) how much tectonic extension, if any, has been taken up by dike intrusion or caldera collapse within the OVC. Addressing these questions will help to determine whether volcanism drives fault displacement or vice versa.

\subsection{Methods \& Data}

A digital elevation model [this chapter] combined with pre-existing geological data (e.g. volcanic unit distribution and rift architecture [Nairn, 2002; Rowland \& Sibson, 2001; Villamor \& Berryman, 2001; Acocella et al., 2003; this study]), in association with seismic reflection lines [Davy \& Bibby, 2005; Chapter 2] and gravity data [Chapter 2] allow fault displacements to be measured within, and up to $30 \mathrm{~km}$ along strike away from, the OVC.

In the following sections (3.2.1-3.2.5) the techniques used in this chapter to acquire, process and analyse the principal data are described. These data sets are: i) a topographic digital elevation model (DEM), ii) seismic reflection lines; and iii) gravity modelling. Each of the data sets provides information on fault displacement over different depths ranging from the ground surface (topographic analysis), to 100's of meters (seismic reflection), to kilometres (gravity).

\subsubsection{Topographic analysis}

The Taupo Rift comprises active normal faults which displace the ground surface. Active fault surface traces mapped along their lengths indicate the presence of a dense array of interacting faults that reach lengths of up to ca. $28 \mathrm{~km}$ [Villamor \& Berryman, 2001; Nicol et al., 2006]. Active faults adjacent to the southwest margin of the OVC displace topographic surfaces that include planar volcanic, fluvial and lake sediment constructional surfaces into which stream erosion has produced valleys. 

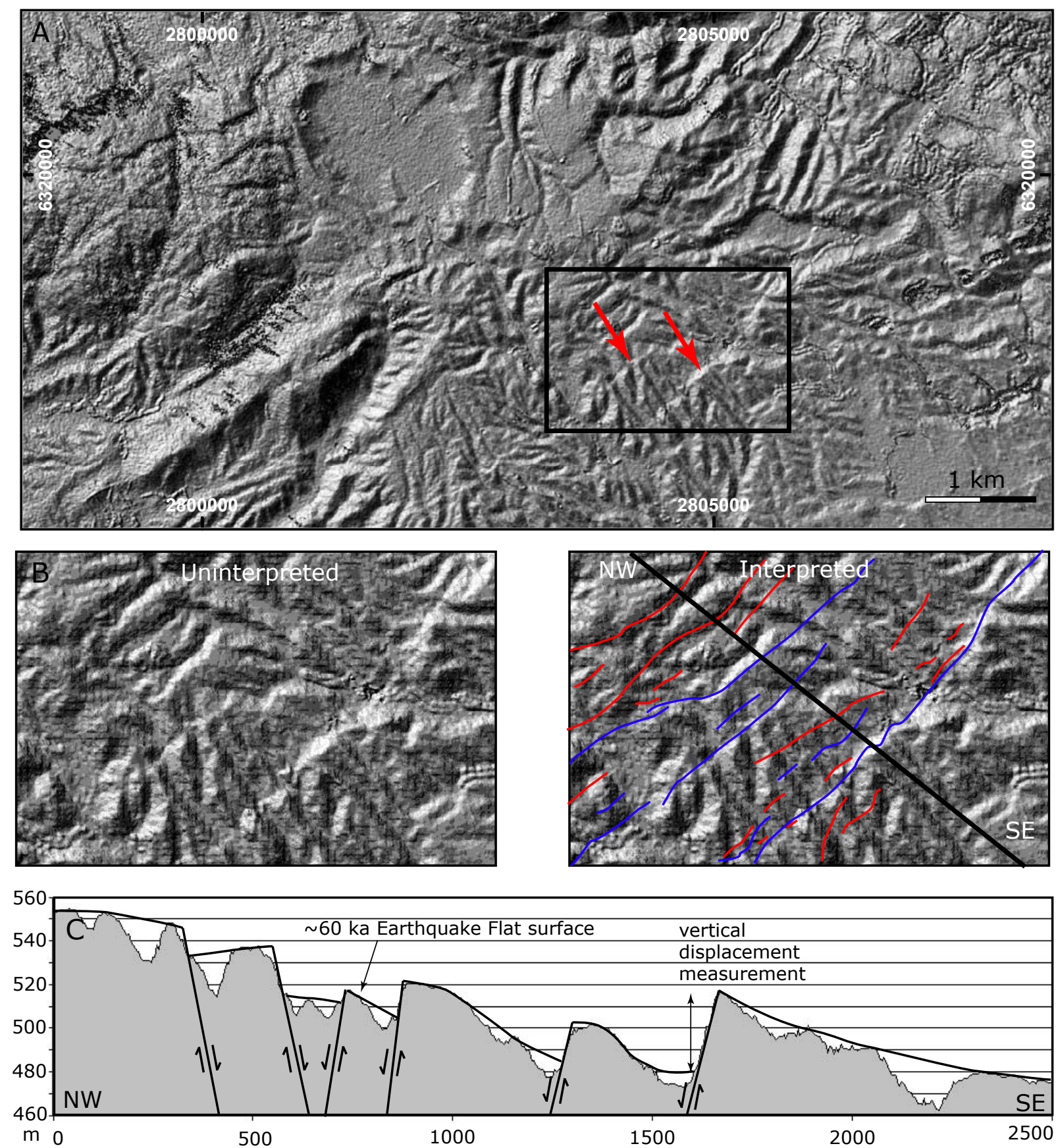

Fig. 3.2. Example of digital elevation model (DEM) showing measurement of vertical fault displacement. (A) Map view of TOPSAR 5m grid DEM of Earthquake Flat area. Northeast striking fault scarps can be seen within the box (red arrows) (B) Interpretation of fault traces from 1:17 000 georeferenced aerial photographs. Northwest-southeast line is cross-section in (C). (C) Example cross-section across Earthquake Flat Pyroclastic $60 \mathrm{ka}$ horizon [Nairn, 1989] showing gently dipping fan surface dissected by normal faulting. Fault scarps are measured at all suitable locations along each individual fault trace in (B). (D) DEM displacement measurements verses field observations for individual locations (Fig. 3.3 and 3.4).

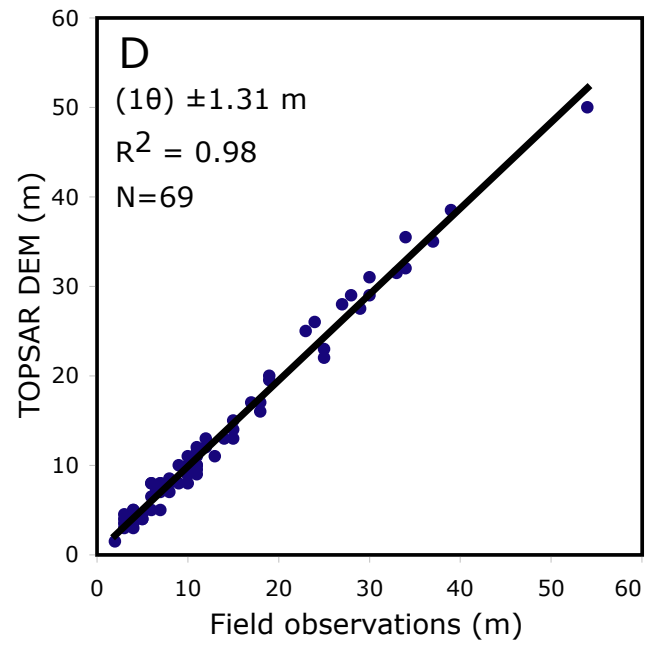


Measurement and analysis of active fault displacements $(\geq 1.5 \mathrm{~m})$ was conducted using high resolution synthetic-aperture radar (TOPSAR) digital elevation models (Fig. 3.2) and RTK GPS surveying of fault scarps (for full details on the construction and resolution of the TOPSAR digital elevation model refer to Appendix II). Faults were mapped using 1:17 000 vertical aerial photographs, existing 1:50 000 scale geological maps [Nairn, 1989, 2002], and field mapping. To extend the topographic fault analysis into the caldera complex and to assess the role of regional faults during caldera collapse, sub-surface (i.e. within $900 \mathrm{~m}$ of lake bed) fault locations and vertical displacements were estimated in Lake Tarawera using reinterpreted seismic reflection lines (Fig. 2.9) [Davy \& Bibby, 2005; Chapter 2]. In addition, an extensive regional gravity dataset [Chapter 2] covering an area of $150 \times 150 \mathrm{~km}^{2}$ has been used to examine the influence of faulting and caldera collapse on the geometry of the minimum depth to top basement.

To assess the impact of volcanism on fault growth across the margin of the OVC, fault displacement and displacement rates have been measured along the Paeroa and Whirinaki fault zones (Fig. 3.3 \& 3.4). The Paeroa Fault zone extends ca. 28 km southwest from the south-west margin of the OVC is one of the most active faults in the Taupo Rift with displacement rates of 1.5-2.0 mm/yr over the last $300 \mathrm{kyr}$ [Villamor \& Berryman, 2001]. The geometric complexity of the fault varies along its 040-050 ${ }^{\circ}$ strike. The southern half of the fault is expressed in welded ignimbrite units ( $\leq$ c. $730 \mathrm{ka}$ in age) and consists primarily of one strand, splaying into two main strands (locally three) in the central segment, all downthrown to the northwest. The $10 \mathrm{~km}$ long northern segment extends up to the south-western margin of the OVC forming a $1.5 \mathrm{~km}$ wide graben with spatially distributed surface faulting (comprising up to 13 strands) across relatively unconsolidated 60 ka Earthquake Flat Pyroclastics (Fig. 3.3) [Nairn, 1989; Villamor \& Berryman, 2001]. The graben reaches within $1 \mathrm{~km}$ of the south-western termination of a $17 \mathrm{~km}$ long alignment of vents formed during the $1886 \mathrm{AD}$ basaltic dike intrusion of Tarawera [Nairn \& Cole, 1981]. The change in the geometric complexity of the fault zone along strike from southwest to northeast may arise due to the increasing thickness of relatively unconsolidated volcanic rocks in this direction. The northward increase in the number of strands along the Paeroa Fault zone coincides with an increase in the depth to top basement determined from gravity modelling. A gravity profile along strike of the fault reveals a change in the depth to basement, by approximately $1 \mathrm{~km}$, coincident with the change in fault complexity observed at the surface (Refer to section 3.3.2 \& Fig. 3.7). The positive relation between depth to 
basement, fault zone width, and complexity suggests that within basement, the Paeroa Fault is likely to be a relatively simple structure comprising a single primary slip surface.

The Whirinaki Fault zone is approximately $30 \mathrm{~km}$ in length primarily dipping to the northwest [Villamor \& Berryman, 2001]. The fault zone bifurcates into two main structures striking $\sim 040^{\circ}$ and $\sim 065^{\circ}, 15 \mathrm{~km}$ from the topographic caldera margin (Fig. 3.4). These two faults define a $3 \mathrm{~km}$ wide zone that comprises up to 11 strands, some of which can be traced into the Okataina Caldera. Like the Paeroa Fault zone, the location of the widening of faulting in the Whirinaki Fault zone (after Nairn, 1989) appears to coincide with a deepening of top basement (e.g. Fig. 2.3)

\subsubsection{Seismic reflection lines}

Seismic reflection lines [Davy \& Bibby, 2005] collected across Lake Tarawera have been used to constrain the location of subsurface faulting within the topographic margin of the Okataina Caldera and to provide additional fault displacements for fault strands within the Whirinaki Fault zone (Fig. 2.9). The seismic reflection data have been collected, processed, and published by Davy \& Bibby [2005]. Refer to Chapter 2 for details of identification of primary reflectors, fault locations, and age interpretation, and to Davy \& Bibby [2005] for details of seismic acquisition and processing. Displacements were measured in two-way travel time and converted to metres using the following velocities; $1450 \mathrm{~m} / \mathrm{s}$ for the water layer, $1600 \mathrm{~m} / \mathrm{s}$ to $500 \mathrm{~m}$, and $2200 \mathrm{~m} / \mathrm{s}$ for depths below $500 \mathrm{~m}$. Uncertainties in seismic reflection data are discussed in section 3.2.4.

\subsubsection{Gravity models}

Multi-1D gravity modelling has been utilised to estimate the minimum depth of the top basement over an area of 50 x $80 \mathrm{~km}^{2}$ in the central and northern Taupo Rift (including the OVC). The geometry of the minimum depth to top basement is used to identify the caldera margin and displacements of the larger faults in the rift at depths of 1-4 km. Gravity modelling generally permits fault vertical displacements of $>500 \mathrm{~m}$ to be estimated. Gravity derived minimum basement altitudes provide a first order estimate of the total vertical displacement across the rift and Okataina Caldera. Details of methods used to estimate minimum basement depths across the Okataina region are described in Chapter 2. The minimum depth to basement derived from 1D gravity modelling is relative to the ground surface, as are the majority of independent constraints used to constrain the gravity depth function (Table 6.2). To allow comparison between the 
modelled and observed basement depths no correction has been applied for altitude above sea-level whereas for the measurement of minimum basement altitude, the data set has been referenced against sea-level. While this smoothed multi-1D basement model does not accurately reflect structural features (i.e. dip angle on faults) it does provide a first order surface with which to estimate the minimum cumulative vertical displacements of faults between the rift axis and the rift margins.

\subsubsection{Fault displacement uncertainties}

Vertical fault displacements range from $1.5 \mathrm{~m}$ to $80 \mathrm{~m}$ on topographic surfaces ranging in age from $\sim 10$ ka to 220 ka [Nairn, 2002; this study]. Higher displacements are generally observed on older surfaces suggesting that many faults accrued slip during much of the last 220 kyr. Typical resolvable vertical offsets on the TOPSAR digital elevation model are $\geq 1-2 \mathrm{~m}$ where the active fault trace displaces a surface isolated from stream channels and vegetation, $\geq 3-4 \mathrm{~m}$ in areas where fault scarp erosion is observed and $\geq 10 \mathrm{~m}$ in forested areas. To test the accuracy of displacement measurements taken from the $5 \mathrm{~m}$ grid TOPSAR digital elevation model, these data have been compared to displacements measured in the field using RTK GPS or tape measure and level (Fig. 3.2). A standard error $(1 \sigma)$ of $\pm 1.31 \mathrm{~m}$ from this comparison suggests that the TOPSAR digital elevation model accurately records fault scarp height. In addition to uncertainties associated with the measurement technique there are also errors in measurements due to local erosion of the marker surfaces [e.g. Villamor \& Berryman, 2001]. Offset measurements from the TOPSAR digital elevation model incorporates less uncertainty due to local erosion than field measurements by providing the ability to accurately project eroded marker surfaces up to faults (e.g. Fig. 3.2). Total errors on individual throw measurements range from $0.5 \mathrm{~m}$ to $5 \mathrm{~m}$ for throws of 1.5 and $50 \mathrm{~m}$ respectively.

Uncertainties with vertical displacements measured from seismic reflection lines include the velocity model employed by Davy \& Bibby [2005], identification of faults, picking of the primary reflector, and age interpretation. Of these errors, the velocity model and age determination will have the largest influence on the displacement rate. Davy \& Bibby [2005] use a velocity model derived from marine seismic studies of Taupo Caldera [Davy \& Caldwell, 1998] and estimate depths to be less than $\pm 25 \%$ in error. This velocity model predicts sub-surface densities of $\sim 1800-2100 \mathrm{~kg} / \mathrm{m}^{3}$ consistent with those detailed in Chapter 2 (Table 2.1) for saturated unconsolidated OVC volcanic units [Stern, 1982]. 

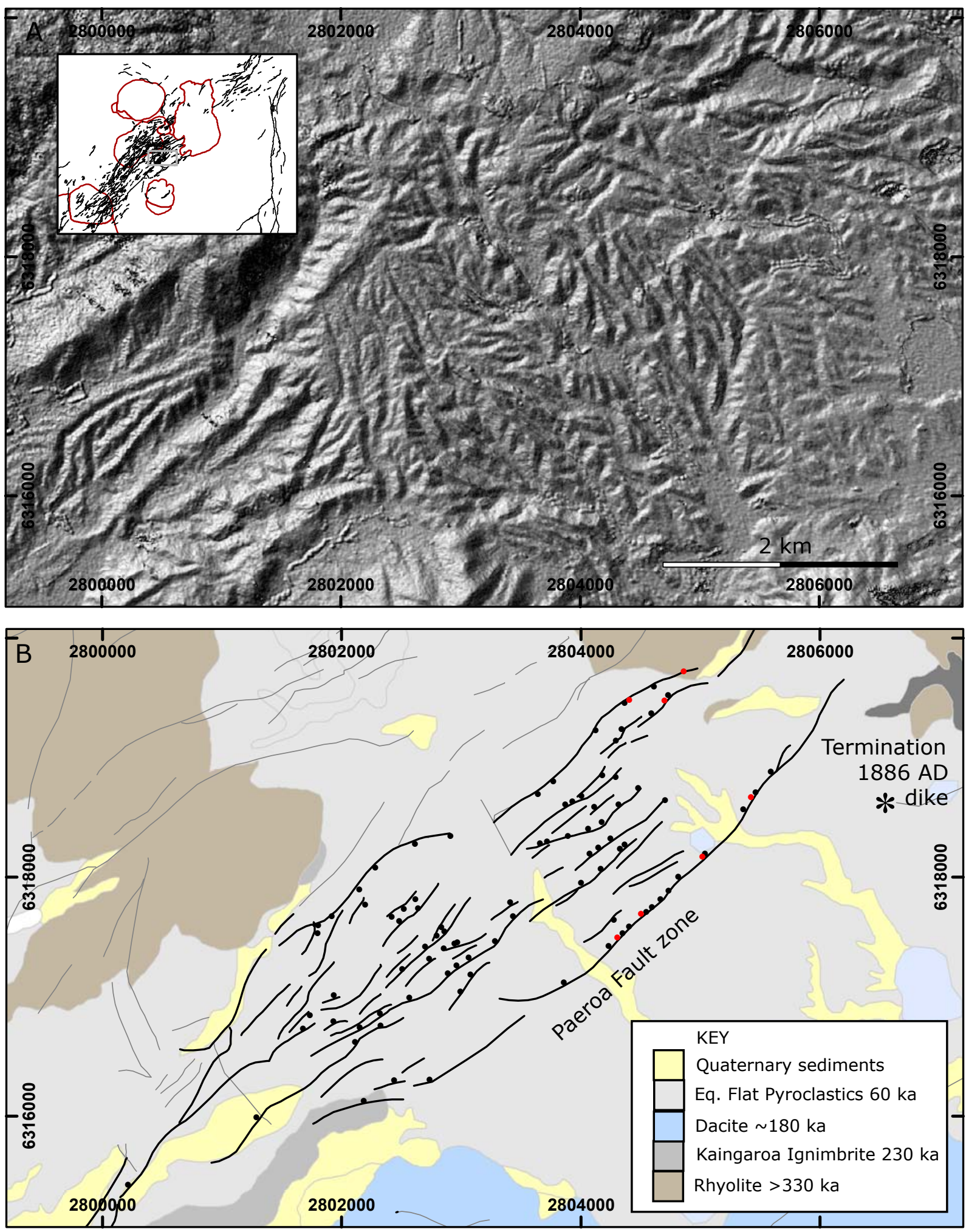

Fig. 3.3. Paeroa Fault zone adjacent to the south-western margin of the OVC. (A) Uninterpreted $5 \mathrm{~m}$ grid TOPSAR DEM used to extract displacement data from fault scarps. (B) Simplified geology and active faults (grey lines) including Paeroa Fault zone (black lines ) with displacement measurement locations shown [Nairn, 1989; this study]. DEM (black filled circles) and field (red filled cirles) displacement measurements typically spaced at 50-500 m along individual fault traces with scarps higher than 1-2 m. 'Earthquake cracks' associated with, and adjacent to, pre-existing fault scarps along a $\sim 5 \mathrm{~km}$ section of the fault zone (Fig. 3.5) [Smith, 1886] occurred $\sim 1 \mathrm{~km}$ from the southern termination of the 1886 AD dike intrusion (black asterisk). 

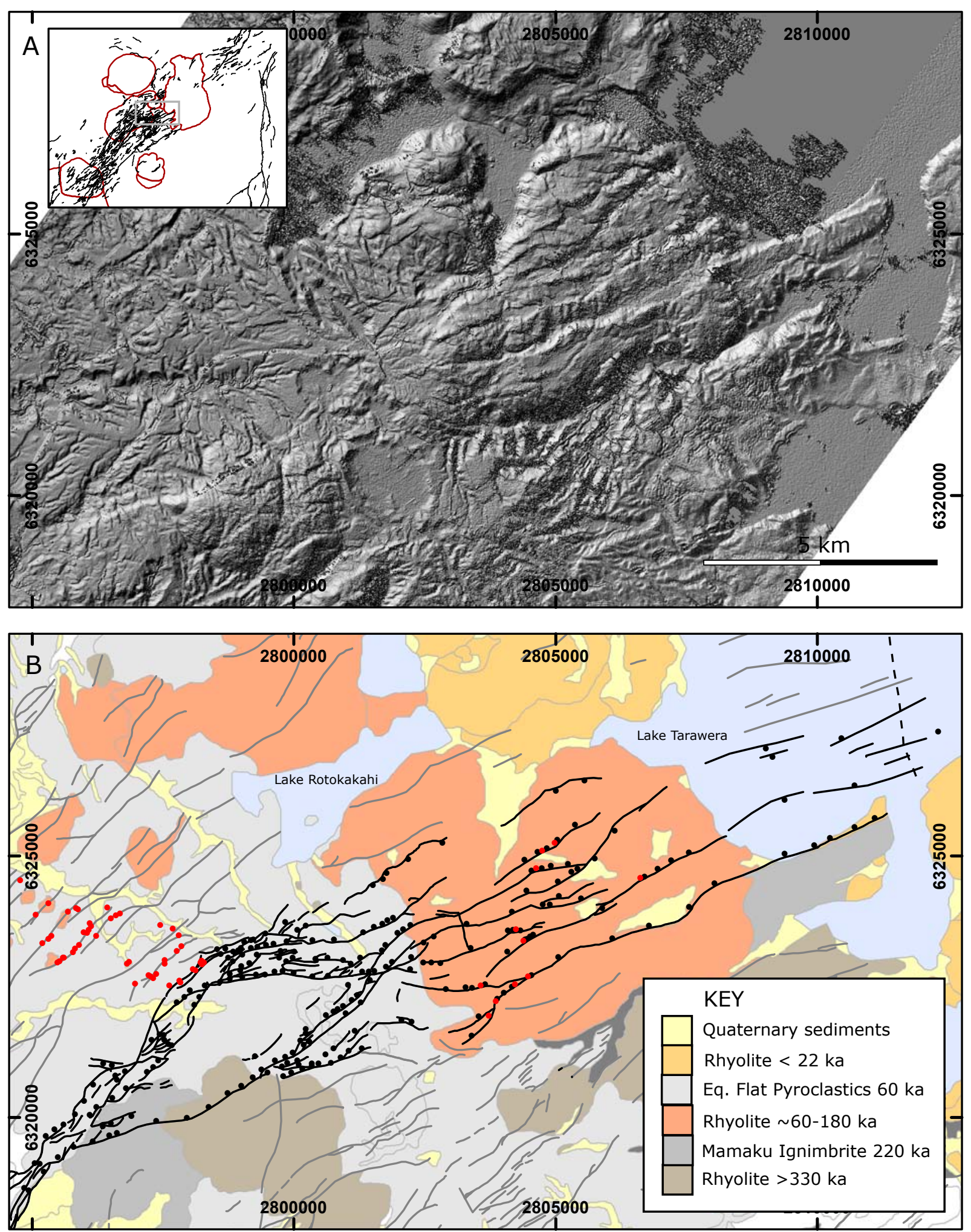

Fig. 3.4. Whirinaki Fault zone adjacent to the western margin of the OVC. (A) Uninterpreted 5 $m$ grid TOPSAR DEM used to extract displacement data from fault scarps. (B) Simplified geology and active fault map (grey lines) including Whirinaki Fault zone (black lines) with displacement measurement locations shown [Nairn, 1989; this study]. DEM (black filled circles) and field (red filled cirles) displacement measurements typically spaced at 50-500 m along individual fault traces with scarps higher than 1-2 m. Fault location and displacement measurements within Lake Tarawera obtained from reinterpreted seismic reflection lines of Davy \& Bibby [2005] (e.g. Fig. 2.9b-c). 
The locations of faults have been estimated by the truncation and offset of continuous reflectors, while vertical displacements were measured across the ' $M$ ' horizon, i.e. the top of the 220 ka Mamaku Ignimbrite. Uncertainties in the depth estimation to the ' $\mathrm{M}$ ' horizon (Fig. 2.9) arise from the ability to recognise individual, closely-spaced reflectors. The maximum vertical resolution on a recorded seismic section is between one-quarter and one-eight of the dominant wavelength of reflected seismic pulse [Kearey et al., 2002]. For example, a seismic signal with a dominant frequency of $50 \mathrm{~Hz}$ propagating though $2.0 \mathrm{~km} / \mathrm{s}$ sedimentary or volcanic strata has a wavelength of $40 \mathrm{~m}$ and a vertical resolution no less than $10 \mathrm{~m}$ [Kearey et al., 2002].

Uncertainties in the gravity model used in this study are discussed in Chapter 2. For the purposes of this analysis, estimates of a minimum depth to basement (i.e. a composition density of $2670 \mathrm{~kg} / \mathrm{m}^{3}$ ) would be influenced by vertical or horizontal density variations unaccounted for in the gravity model. Rogan [1980] suggests a \pm 3 $\mathrm{mGal}$ tolerance on any gravity model estimate of basement depth through the analysis of the effect of a variable density structure with depth about a mean. At basement depths typically associated with the TVZ (e.g. 2 km) this equates to $\pm 300-400 \mathrm{~m}$ (i.e. 15-20\% of the estimated depth) using an initial surface density contrast of $670 \mathrm{~kg} / \mathrm{m}^{3}$ and an exponentially decreasing density decrement of $0.4 \mathrm{~km}^{-1}$ (Fig. 2.5).

Age control for the faulted topographic surfaces permits displacement rates to be estimated, typically at multiple points along individual faults. As no one faulted surface horizon can be traced into the OVC, displacement rates are used to assess the impact of volcanism on faulting (e.g. Fig. 3.4). In the area of study, the principal faulted topographic surfaces are 60 ka (Earthquake Flat Pyroclastics) [Nairn, 2002], 188 ka (Tutaeheke rhyolite dome) [Leonard unpublished data, 2007], and 220 ka (Mamaku Ignimbrite) [Houghton et al., 1995], with the majority of incised valleys abandoned at approximately $18 \mathrm{ka}$ [Nicol unpublished data, 2007]. These surfaces have been dated by a combination of $\mathrm{Ar} / \mathrm{Ar}, \mathrm{K} / \mathrm{Ar}$, and radiocarbon methods.

These ages have been used to calculate time-averaged displacement rates for the periods of time since surface formation. By using different aged surfaces it was possible to measure multiple $(\mathrm{N}=20)$ displacement rates along the lengths of the longest fault traces (i.e. $>5 \mathrm{~km}$ ) and the Whirinaki and Paeroa fault zones. Implicit in the use of different aged surfaces to record displacement rate variations along faults is the assumption that at any point on a fault trace the displacement rates were constant over the last 220 kyr. Measurement of displacement rate on individual faults within the rift immediately southwest of the study area supports this assumption suggesting that rates 
were approximately constant over time intervals of 60 to $280 \mathrm{kyr}$ [Villamor \& Berryman, 2001; Nicol unpublished data, 2008].

\subsubsection{Cumulative fault zone profiles}

Vertical displacements were measured 50-1000 m apart along all resolvable onshore fault traces approaching the western margin of the volcanic complex (over an area of 18 by $10 \mathrm{~km}^{2}$ ) have been used to construct displacement profiles along individual fault traces. Individual measurements were aggregated across a transect line normal to average fault strike to produce cumulative displacement profiles for multiple traces within the Paeroa and Whirinaki Fault zones. For the Paeroa Fault zone, seven transect lines sample all resolvable fault traces within, and bounding, the graben which defines the northern tip zone of the fault [Villamor \& Berryman, 2001]. Twenty transects have been used to chart displacement rates along the Whirinaki Fault zone. The south-eastern margin of the Whirinaki Fault zone is defined by two large displacement (i.e. 50-150 m) northwest dipping faults. The north-western margin of the fault zone is defined by a series of faults which dip to the northwest and southeast. Like the Paeroa Fault zone, the northern part of the Whirinaki Fault zone forms a graben. The lengths of each transect remain approximately constant $(\sim 3 \mathrm{~km})$ for much of the sampled length of the fault zone.

The cumulative displacement data derived in this study are consistent with two published displacement rate measurements for the Paeroa Fault, one of which is included in this analysis [Villamor \& Berryman, 2001 Fig. 11]. The cumulative fault displacement rate for the Whirinaki Fault zone is also consistent with a displacement rate derived from paleoseismic trench data for the 9.5 ka Rotoma Tephra horizon [Villamor \& Berryman, 2001 Fig. 10].

The location of maximum subsidence within the Okataina Caldera, as defined by gravity modelling [Chapter 2], is used as a reference point from which to measure distance along the strike for each displacement measurement and cumulative transect. These data allow displacement and displacement rate changes to be mapped with reference to the topographic and inner collapse structures of the caldera. Specifically, these data permit the influence of dike intrusion and caldera collapse on fault displacements to be examined.

\subsection{Dike and Fault interaction}

A basaltic dike intrusion reached the ground surface and terminated within $1 \mathrm{~km}$ of the Paeroa Fault zone during the 1886 AD Tarawera eruption (Fig. 3.3) [Smith, 1886; Nairn 
\& Cole, 1981]. These close spatial relations together with fault displacement data and a historical account during the 1886 AD Tarawera eruption [Smith, 1886] permits investigation of the interaction between dike intrusion and fault slip. The 1886 AD Tarawera eruption (and associated phreato-magmatic explosions) was accompanied by the injection of a basaltic dike along a $\sim 17 \mathrm{~km}$ dike/fissure system (Fig. 3.5) [Nairn \& Cole, 1981]. The south-western end of the dike terminated near normal fault traces that displace the 60 ka Earthquake Flat Pyroclastic fan surface forming part of the Paeroa Fault zone, $4 \mathrm{~km}$ from the topographic caldera margin [Villamor \& Berryman, 2001; Nairn, 2002].

The $1886 \mathrm{AD}$ dike and basaltic vents dissect the Tarawera Volcanic Complex and south-eastern topographic caldera margin, terminating in a rhyolitic dome (96 \pm 22 ka) at Waimangu [Nairn \& Cole, 1981; Leonard unpublished data, 2007]. The dike has an average measured thickness of $\sim 2 \mathrm{~m}$ at the ground surface while modelling of the magnetic anomaly across the dike suggests that it may reach a thickness of $5 \mathrm{~m}$ within 10's of metres of the ground surface [Nairn \& Cole, 1981; Rogan \& Hochstein, 1984]. If $5 \mathrm{~m}$ of horizontal dike extension were accommodated by dip-slip on $70^{\circ}$ dipping faults southwest beyond the dike termination, then a total throw of $\sim 14$ m could accrue on the fault(s) in the Paeroa Fault zone due to dike intrusion. Here, individual and cumulative fault displacement profiles from the Paeroa Fault zone have been used to examine the effect of dike termination on fault displacements and displacement rates. These data are combined with historical accounts of the 1886 AD eruption [Smith, 1886] and the results of fault trenching from Berryman et al. [in review].

\subsubsection{Faulting associated with 1886 AD eruption}

Smith [1886] reported the formation of 'earthquake cracks' up to $4.5 \mathrm{~km}$ southwest of the southern termination of the 1886 AD Tarawera basaltic vents (great fissure of Smith) (Fig. 3.5). These 'earthquake cracks' were typically 0.05-1.5 m wide occurring along, and half way up, existing steep fault scarps which ranged in height from 0.3-26 m [Smith, 1886]. The 1886 'earthquake cracks' coincide with active fault traces, supporting the view that cracks opened along pre-existing faults. The 1886 AD 'cracks' have lengths of 0.5 to $2.5 \mathrm{~km}$ and are generally shorter than the fault scarps they formed along suggesting that only parts of each fault scarp cracked during the eruption (Fig. 3.8). 


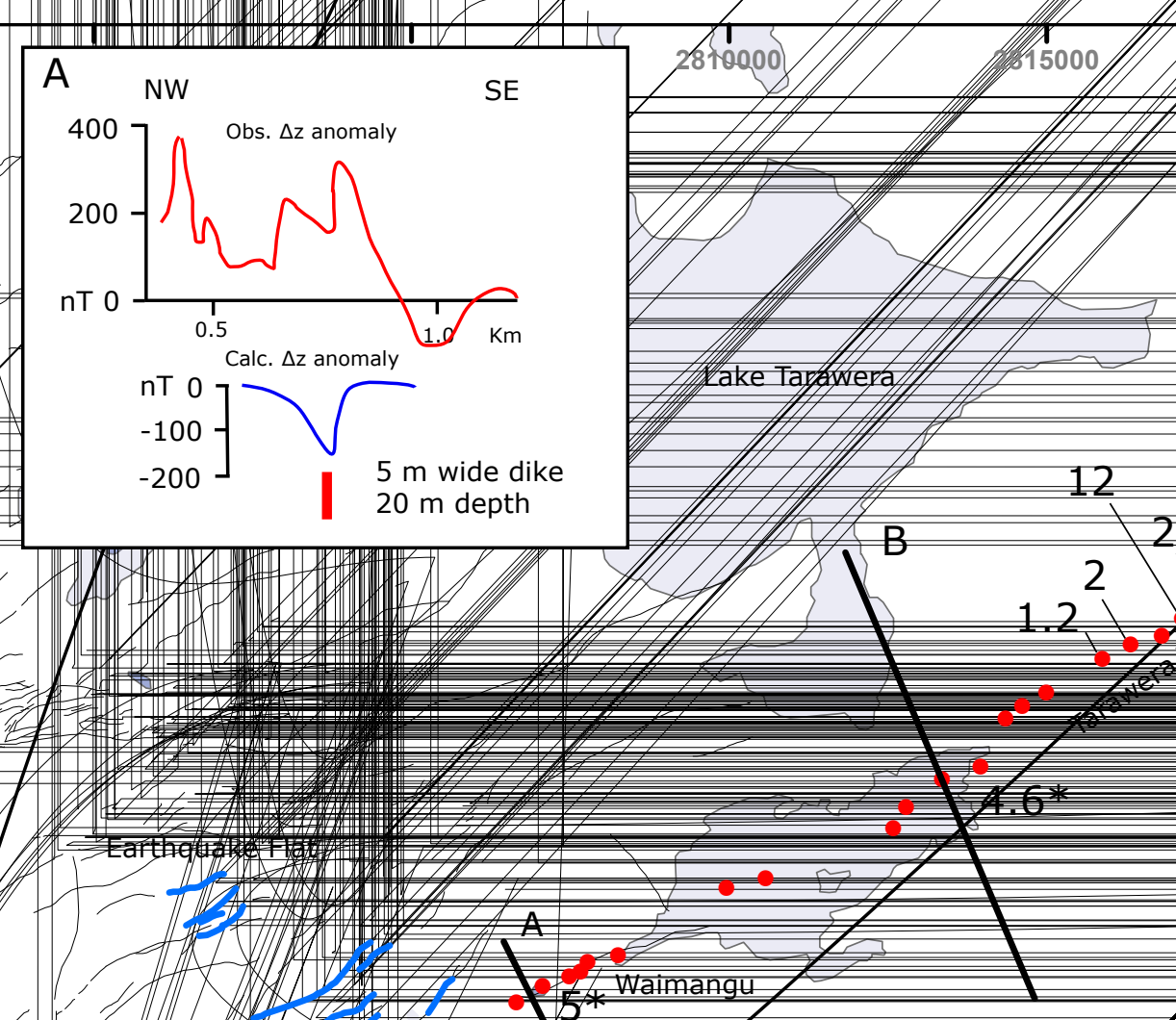


Observations made by Smith [1886] in the weeks following the eruption suggest that the 'earthquake cracks' primarily accommodated opening with little or no shear displacement of the ground surface. Trenches across fault traces in the Paeroa Fault zone appear to support the historical data and indicate no dip slip associated with cracking of the ground immediately prior to, during or following deposition of the 1886 $\mathrm{AD}$ eruptive material [Berryman et al., in review]. In particular, the Fraser-Pain trench, excavated across a segment of a fault trace that appears to have ruptured in $1886 \mathrm{AD}$, shows no evidence of dip slip displacement during the last 300-400 years [Berryman et al., in review].

The absence of shear displacement on the $1886 \mathrm{AD}$ 'cracks' does not preclude the possibility of dip slip on the faults at depth during dike intrusion. In the 1987 Edgecumbe earthquake, for example, fault slip at depth in places produced monoclinal folding and associated dilational fissures at the ground surface [Beanland et al., 1989]. In addition, it remains possible that cracking of the ground surface in 1886 AD reflects crustal scale dilation and/or near surface gravitational processes.

One of the largest 1886 AD ‘earthquake cracks’ occurred at Earthquake Flat and, although modified by farming, can still be observed today. Unlike the majority of the 1886 AD 'cracks' these form elongate depressions along the base of fault scarps. These depressions appear to be a series of tomos (a form of subsurface erosion and collapse of permeable soils caused by the movement of ground water). In support of the tomo interpretation, Smith [1886] reported after a night of heavy rain the opening of a subterranean drainage channel within porous unconsolidated material at the base of a valley floor fault scarp. Thus, while the Earthquake Flat 'cracks' formed during (or soon after) the $1886 \mathrm{AD}$ eruption, they do not appear to directly record crustal scale (e.g. $\mathrm{km})$ magmatic or tectonic processes.

The origin of 'earthquake cracks' outside Earthquake Flat requires further investigation. To examine the possibility that some of the fault traces proximal to the dike experienced monoclinal folding in $1886 \mathrm{AD}$ (which would be recorded by measurement of fault scarp heights), displacement rate profiles have been constructed along the Paeroa Fault zone and across the dike termination (Fig. 3.6).

\subsubsection{Paeroa Fault zone along-strike displacement rates}

To test the influence of dike intrusion on faulting, displacements for individual fault traces have been collated along the Paeroa Fault zone and across the south-western 
termination of the dike (Fig. 3.6). As the faults and dike strike at a shallow angle $\left(\sim 15^{\circ}\right)$ to each other, the projected intersection of dike and faults can only be located to $\pm 1 \mathrm{~km}$. Cumulative displacement rates along the Paeroa Fault zone are approximately constant along much of the profile (Fig. 3.7) despite the change in the complexity of fault geometry. The northward increase in the spatial distribution and number of fault strands is however accompanied by an increase in total displacement rate on southeast dipping faults in the zone. This increase in displacement rate of southeast dipping faults is accompanied by decrease in total displacement rates on northwest dipping faults. These equal and opposite changes in displacement rates suggest that fault traces within the graben at the northern end of the Paeroa Fault zone are part of a kinematically coherent fault array. This coherence supports the interpretation that the graben is part of the Paeroa Fault zone.

Displacement rate profiles have been produced for three fault traces within the Paeroa Fault zone, which are here referred to as the northern, central, and southern strands (Fig. 3.6). All three strands are segmented. The northern and central strands generally have stable vertical displacement rates since 60 ka over distances of 4-5 km and across the dike termination zone. The southern strand, which is the closest fault trace to the termination of the $1886 \mathrm{AD}$ dike, displays a stable vertical displacement rate that increases by a factor of three near the dike termination zone. This rapid increase in displacement rate across the dike termination could be interpreted to arise from the dike intrusion. However, the increase in displacement rates on the southern strand is not mirrored by an increase in cumulative rates across the entire zone which are approximately constant along the zone at $1.53 \pm 0.1 \mathrm{~mm} / \mathrm{yr}$. Stable cumulative displacement rates suggest that the rise in rate on the southern strand of the fault zone is matched by a decrease of rates on fault traces elsewhere within the zone (displacement profiles for these faults have not been produced for this study). The apparent interdependence of fault displacements is consistent with the notion that all fault traces within the zone are kinematically interacting [Nicol et al., 2006].

Displacements and displacement rates along the Paeroa Fault zone do not change significantly across the southwest termination of, or with increasing proximity to, the dike. Therefore, the available historical, paleoseismic and geomorphic information provide little support for the view that dike intrusion in $1886 \mathrm{AD}$ resulted in dip slip on faults in the Paeroa Fault zone. 

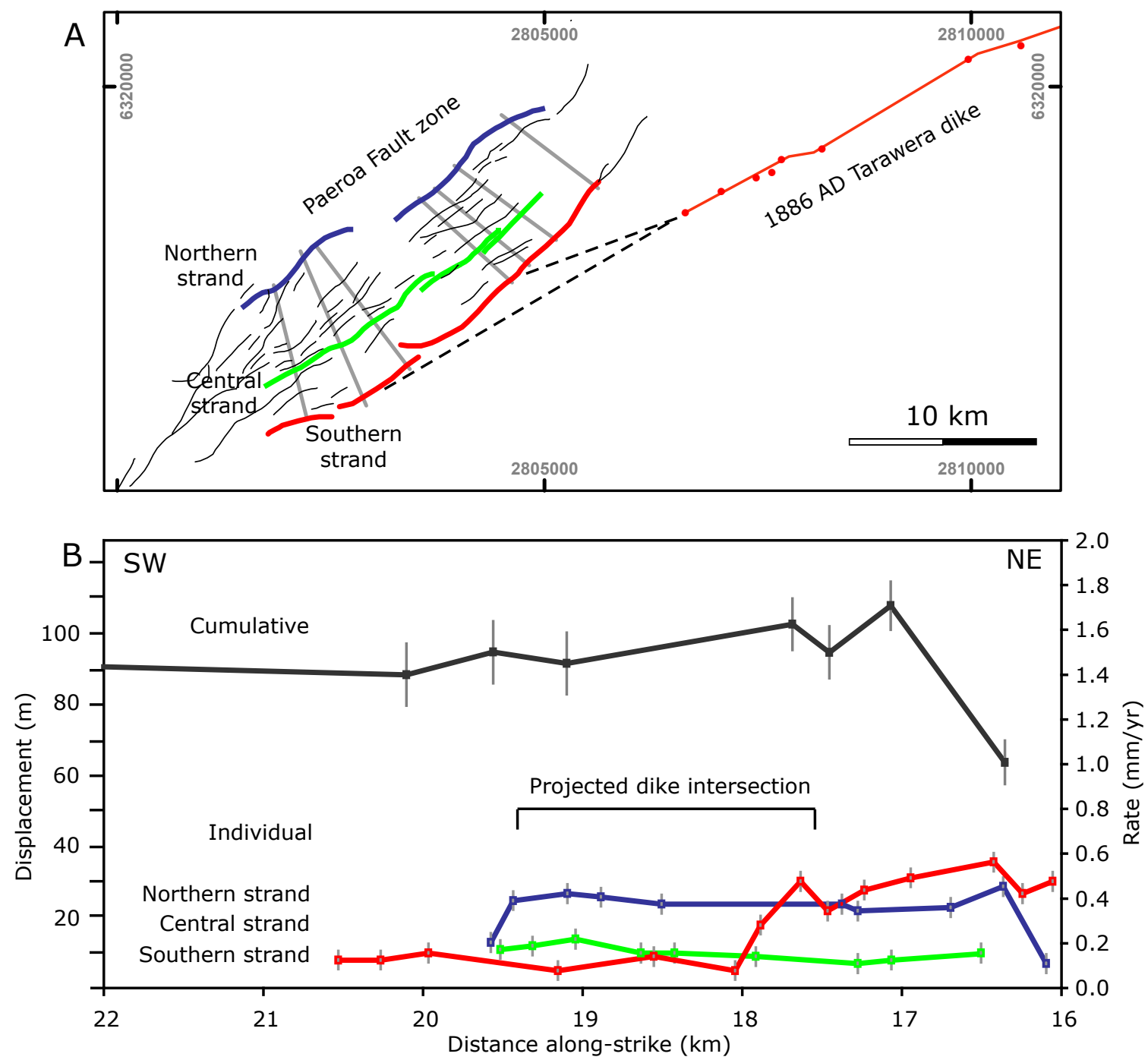

Fig. 3.6. Displacement along the Paeroa Fault zone across the southern termination of 1886 AD dike intrusion. (A) Map of Paeroa active fault traces detailing location of cumulative profiles (grey lines) perpendicular to strike, individual faults profiled (coloured lines) and a projection of the $1886 \mathrm{AD}$ dike intrusion (dashed lines) intersecting the fault zone at an oblique angle. (B) Vertical displacement (and displacement rate) profiles of the Paeroa Fault zone (cumulative) and individual major strands with mapped ground deformation associated with the $1886 \mathrm{AD}$ dike intrusion (Fig. 3.5) [Smith, 1886]. Cumulative displacement rates of this study are consistent with [Villamor \& Berryman, 2001] and show a stable rate along strike towards the termination of the dike and caldera complex. These data show the kinematic coherence of the fault zone, i.e. large displacement rates changes along the southern strand are not reflected in the displacement of the zone as a whole, indicating interaction between faults in the accommodation of displacement across the fault zone [e.g. Nicol et al., 2006]. 

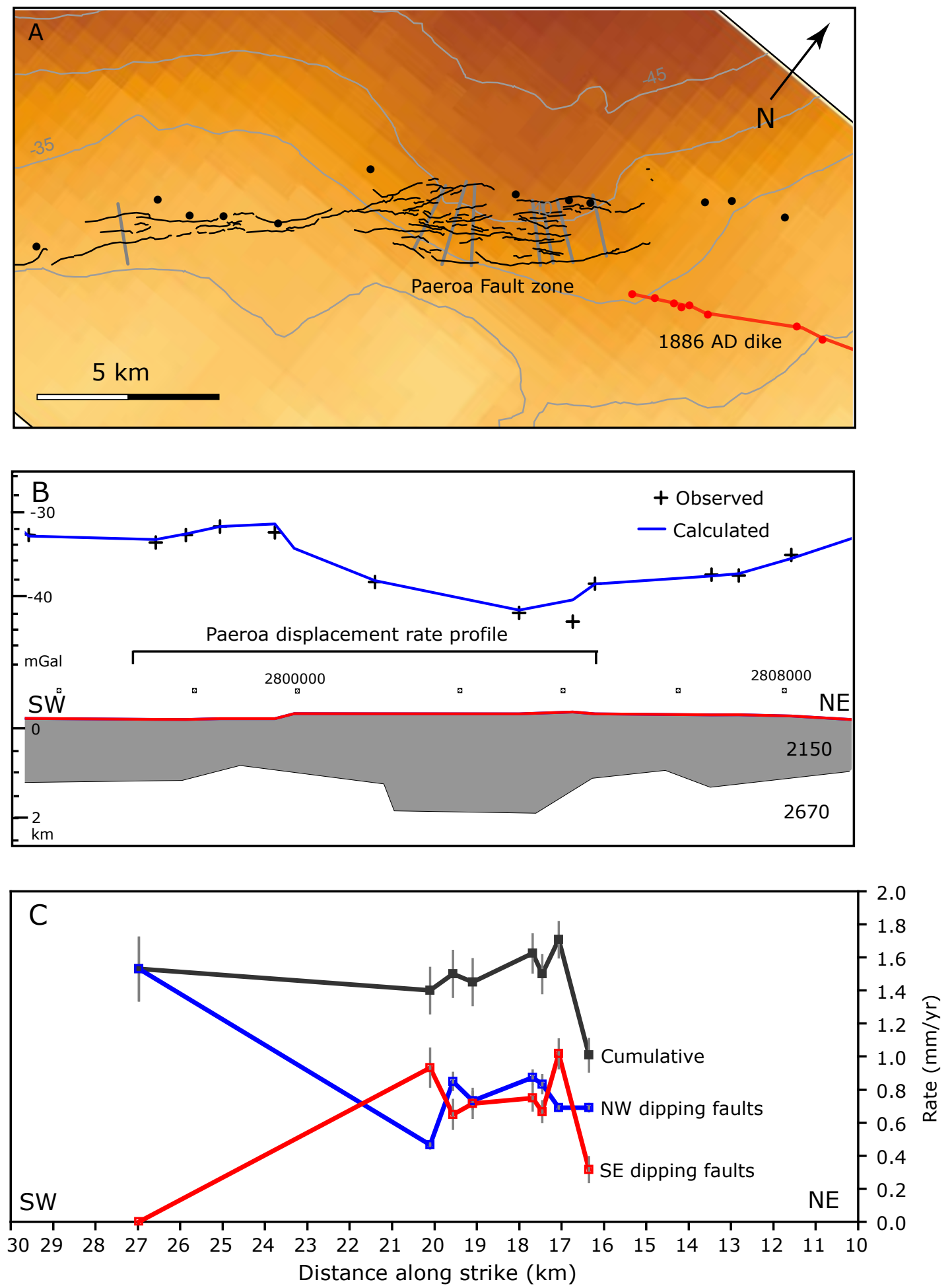

Fig. 3.7. Relations between basement depth, fault style and displacement along the Paeroa Fault zone. (A) Residual gravity map shows decreasing residual gravity values coincident with a change in fault style (e.g. increasing number of strands). Gravity stations (black filled circles) and cumulative displacement transects (grey lines). (B) $2 \frac{1}{2} \mathrm{D}$ gravity model along-strike of Paeroa Fault zone. A -10 mGal decrease in observed gravity values (black crosses) represents a basement depth increase of $\sim 1 \mathrm{~km}$ (C) Cumulative fault displacement rate along-strike of the Paeroa Fault zone [Villamor \& Berryman, 2001, this chapter]. Coincident with an increase in basement depth, total displacement rates on northwest and southeast dipping faults are approximately equal (e.g. slip accumulation on a relatively simple northwest dipping structure to the southwest changes to accumulation across a distributed zone in the northeast.) 
Based on the available data, the 'earthquake cracks' of Smith [1886] are most likely to be near-surface gravitational features produced during seismic shaking that accompanied the eruption. Fissures formed in unconsolidated soils as a result of ground shaking have also been inferred during or immediately prior to the eruption $\left(>30 \mathrm{~km}^{3}\right)$, and associated collapse, of the Taupo Caldera at 1.8 ka [Hughes et al., 2004]. The proximity of this fault zone to the dike and the absence of widespread cracking of the ground surface west of the fault zone during the 1886 AD eruption [Smith 1886] suggest that most rift faults did not accommodate measurable dip slip during the eruption.

The 1886 AD dike intrusion occurred within the $24 \mathrm{~km}$ long Tarawera linear vent zone that has formed during at least 6 eruptions over the last $280 \mathrm{kyr}$ [Nairn, 2002]. A number of these eruptions were accompanied by dike intrusion. For example during the $1315 \mathrm{AD}$ Kaharoa eruption, linear vents formed a $4 \mathrm{~km}$ long segmented rhyolitic dome accompanied by inferred basaltic dikes extending up to $8 \mathrm{~km}$ southwest of the OVC [Leonard et al., 2002; Nairn et al., 2005]. The width of these inferred dikes is not known, however, extension associated with dike intrusion could have triggered slip on rift faults, including the Paeroa Fault zone. However, the profiles in Fig. 3.6 do not indicate a change in cumulative rates approaching the linear vent system and the available displacement data do not provide support for the triggered slip hypothesis. This may be because triggered slip occurred in the Paeroa Fault zone but is subresolution, because triggered slip did not take place in the rift and/or because triggered slip occurred outside the Paeroa Fault zone (i.e. beyond the limits of the displacement data). Given the spatial distribution of ground cracking during the $1886 \mathrm{AD}$ eruption the last option seems unlikely. Therefore, it is proposed that dike intrusion and eruptions along the Tarawera linear vent zone has not significantly modified the accumulation of displacement and growth of the Paeroa Fault zone over the last 60 kyr.

\subsubsection{Dike intrusion and regional extension}

One of the key questions this chapter addresses is what drives displacement on faults within the OVC? (i.e. what proportions of fault displacement can be attributed to tectonic and intrusion processes respectively). Elastic modelling of the 2005 Afar dike intrusion episode suggests up to $8 \mathrm{~m}$ of dilation at depths of 5-6 km [Wright et al., 2006] and represents a feasible mechanism for the accommodation of extension through the OVC. Within the localized caldera structure, dike intrusion is therefore capable of 
accommodating a significant proportion of regional extension during extended periods of magmatism.

Basaltic intrusion has been a feature of the two most recent eruptions from the OVC [Nairn \& Cole, 1981; Leonard et al., 2002; Nairn et al., 2005]. The basaltic intrusion during the $1886 \mathrm{AD}$ Tarawera eruption induced at least $2 \mathrm{~m}$ of dilation within the volcanic complex in near surface volcanic units (Fig. 3.5), and terminated proximal to the Paeroa Fault zone. Unlike Afar and Iceland [e.g. Rubin \& Pollard, 1988; Wright et al., 2006] the 1886 AD Tarawera dike intrusion does not appear to have resulted in significant fault slip at the ground surface outside of the volcanic complex (e.g. Fig. 1.1). The absence of such triggered slip suggests that on the margins of, and outside, the OVC, dilation of the crust due to dike intrusion does not appear to be driving faulting. By contrast, dike intrusion has occurred within the Haroharo and Tarawera linear vent zones over the last 22 kyr [Nairn, 2002; Nairn et al., 2005] and likely accommodated some of the regional crustal extension within the OVC.

The total horizontal extension accommodated by dike intrusion in the OVC is unknown, however, as dikes intersect the ground surface it is expected that the total fault extension across the rift in the upper crust is lower in the OVC than immediately outside it. Thus, the spatial distribution of extension accommodated by tectonic faulting and dike intrusion could be expected to show similar general relations to those depicted in Fig. 3.1c., with some but not all extension in the OVC accommodated by dike intrusion. For example, at a uniform extension rate of $10 \mathrm{~mm} / \mathrm{yr}$ over $22 \mathrm{kyr}$ period, 220 m of horizontal extension would be expected in a northwest-southeast direction across the OVC. The $1886 \mathrm{AD}$ dike intrusion may have produced up to $5 \mathrm{~m}$ dilation in the surface (Fig. 3.5) [Nairn \& Cole, 1981; Rogan \& Hochstein, 1984]. Eleven predominantly rhyolitic intra-caldera eruptions (with an estimated magma volume of c. $85 \mathrm{~km}^{3}$ ) occurred within the OVC over the past $22 \mathrm{kyr}$ [Nairn, 2002]. Dike intrusion could account for $\sim 55 \mathrm{~m}$ of extension in the upper crust if each of these eruptions produced an average dike width of $5 \mathrm{~m}$ (i.e. the maximum for the $1886 \mathrm{AD}$ event). Further investigations are however required to test this hypothesis

\subsection{Caldera collapse and Fault displacements}

Caldera collapse in the OVC utilises, and induces slip on, pre-existing rift faults [Chapter 2]. Measurement of displacements and displacement rates of rift faults that enter the OVC provide a means of examining whether tectonic faults along the Whirinaki Fault zone have also been used for this purpose. 
The collapse of the northern and central part of the Okataina Caldera (including part of the Whirinaki Fault zone) during the 60 ka Rotoiti Pyroclastic eruption (ejecting $\sim 100 \mathrm{~km}^{3}$ of magma from depths of $>6 \mathrm{~km}$ ) is inferred to have produced a strongly scalloped topographic caldera margin [Nairn, 2002; Shane et al., 2006]. This topographic margin formed in association with slumping or collapse of over steepened caldera rims during or immediately after the subsidence of the caldera floor over 400 $\mathrm{km}^{2}$ [Nairn, 2002; Davy \& Bibby, 2005]. Faults of the Taupo Rift (including the Whirinaki Fault zone) cross this topographic caldera boundary in the study area, continuing toward an inner collapse boundary defined by seismic reflection lines and gravity studies beneath Lake Tarawera [Davy \& Bibby, 2005; Chapter 2].

\subsubsection{Whirinaki Fault zone along-strike cumulative displacement rates}

Cumulative displacement rates along the Whirinaki Fault zone are typically in the range of 1 to $1.5 \mathrm{~mm} / \mathrm{yr}$ southwest of the caldera topographic margin (Fig. 3.8). Between the topographic caldera margin and the inner collapse boundary cumulative displacement rates increase up to 3-3.5 mm/yr at a distance of $6 \mathrm{~km}$ from the centre of the caldera. These cumulative rate increases are consistent with an increase of displacement rates along the southern-most strand of the Whirinaki Fault zone (Fig. 3.8), which has vertical displacements of up to $80 \mathrm{~m}$. The southern-most strand has constant $0.25 \mathrm{~mm} / \mathrm{yr}$ displacement rates over $5 \mathrm{~km}$ approaching the topographic margin of the caldera. A sharp increase (factor of four) in the displacement rate on the southern-most strand occurs across the topographic margin towards the inner collapse structure of the caldera.

The topographic caldera margin of Nairn [1989, 2002] steps to the southwest across the southern-most fault strand (Fig. 3.8a) suggesting that during caldera collapse at $\sim 60 \mathrm{ka}$, greater subsidence occurred in the hanging wall of this fault than the footwall. Therefore, both the displacement rates and geometry of the topographic caldera margin indicate that the Whirinaki Fault zone was utilised during caldera collapse at $\sim 60 \mathrm{ka}$ (see also Chapter 2, Fig. 2.8).

The total displacement on the Whirinaki Fault zone due to caldera collapse can be visualised using the models presented in Figs. 3.8c \& 3.1b. Outside of the volcanic complex, rift fault displacements are not significantly influenced by caldera collapse and are considered principally tectonic. Between the topographic margin and inner collapse boundary up to $50 \%$ of the total Whirinaki Fault zone displacement rate is due to caldera collapse, while the other $50 \%$ is tectonically derived fault displacement and approximately equal to the rate outside the caldera complex. 

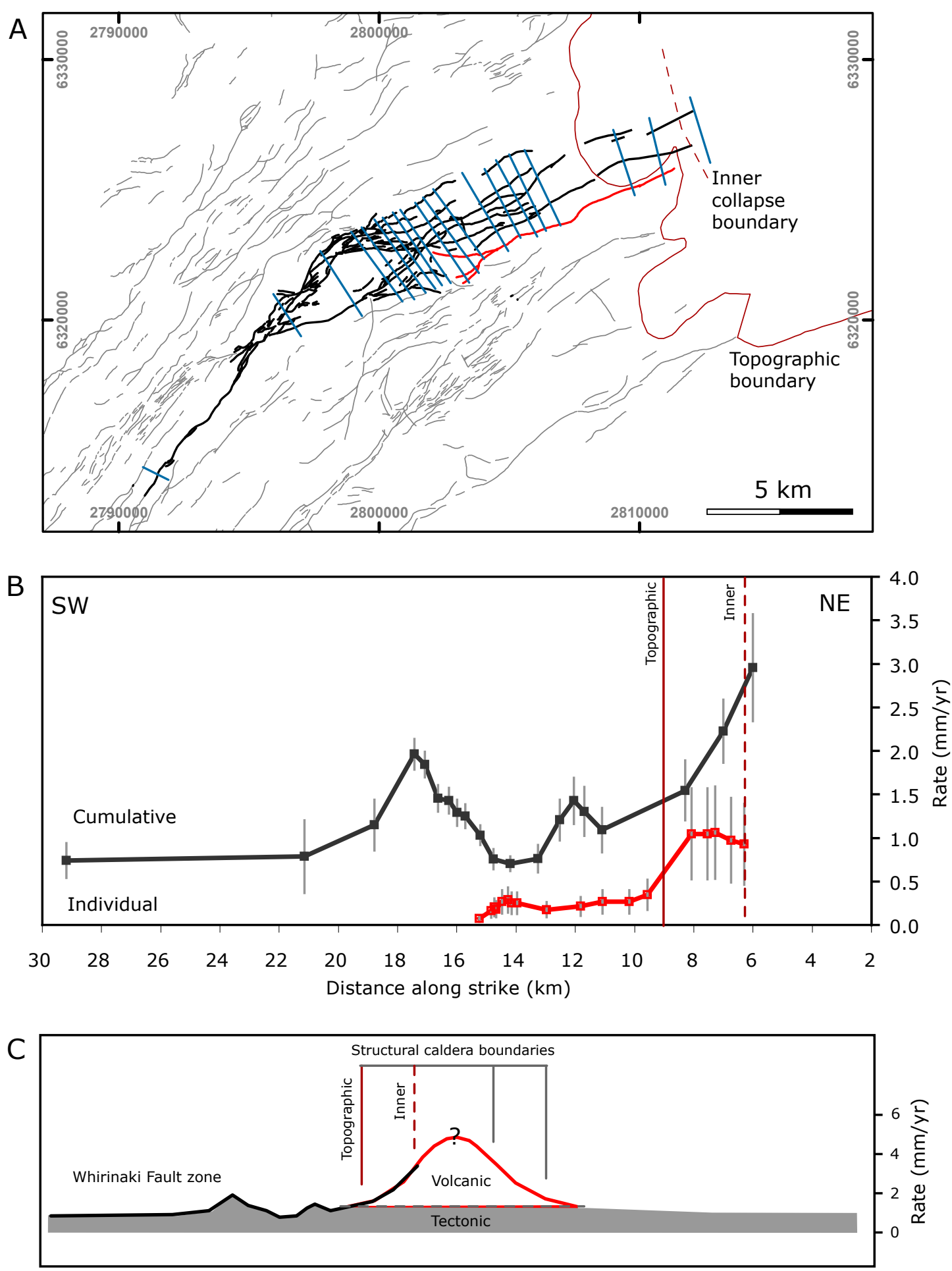

Fig. 3.8. Whirinaki Fault zone displacement rates along-strike towards Okataina Caldera. (A) Location map showing active fault traces (grey lines) includng Whirinaki Fault zone (black/red lines) and cumulative displacement transects (blue lines) relative to the caldera boundaries. (B) Cumulative displacement rates (black line) along-strike towards the caldera complex. Individual fault displacement rate (red line) increases across the topographic caldera boundary. Errors estimated as the square root of the sum of the squares for horizon displacement and age uncertainties. (C) Schematic model of fault displacement interpretation across caldera structure, here a constant cumulative tectonic vertical displacement rate along the Whirinaki Fault zone increases by $>50 \%$ upon entering the caldera complex through the reactivation of rift faults during collapse events. 
Within the inner collapse boundary, the proportion of fault displacement arising due to caldera collapse maybe $>50 \%$, however, insufficient data are currently available to test this suggestion.

\subsubsection{Taupo Rift along-strike displacements}

The potential influence of caldera collapse on rift fault displacements is further examined using vertical separation profiles for the minimum basement horizon defined by multi-1D gravity modelling along the rift [Chapter 2]. The altitude of minimum top basement was measured along the south-eastern and north-western margins, and axis, of the Taupo Rift through the Kapenga and Okataina Calderas to the Bay of Plenty coast (Fig. 3.9). Outside of the two calderas, the altitude difference between the rift axis and rift margins is inferred to record fault throw. Based on displacements from the Whirinaki Fault zone (section 3.4.1) and data from Chapter 2, the altitude difference within the calderas may represent a combination of caldera collapse (some of which occurred on pre-existing faults) and tectonic fault displacements.

Along the rift axis the minimum altitude of the top basement on the caldera floor is typically 1-2 km below minimum top basement outside the calderas, while the southeast rift margin is up to $1.5 \mathrm{~km}$ higher than the northwest margin (Fig. 3.10). The height difference between the margins may have arisen because the north-western margin of the active rift was once further west (e.g. at the western margin of the Central Volcanic Region) and has only been in its present location for the last 300-500 kyr [e.g. Villamor \& Berryman, 2006; Mouslopoulou et al., 2008]. Prior to this time the northwest margin of the active rift was down-faulted relative to the southeast margin and hence the northwest margin is now at a lower altitude.

Vertical separation profiles indicate that within the Kapenga and Okataina calderas, up to 2-3 km of separation could be attributed to caldera collapse (Fig. 3.10b). Between the calderas a further 2-4 km may be due to tectonic fault throw. Precisely how much of the vertical separation due to caldera collapse was achieved on pre-existing faults is not known. However, the Kapenga Caldera is located within, parallel and elongate to the rift, while the north-western and south-eastern margins of the Okataina Caldera are defined by rift faults [Chapter 2]. Therefore, in both cases, rift faults may have played an important role in caldera formation. 


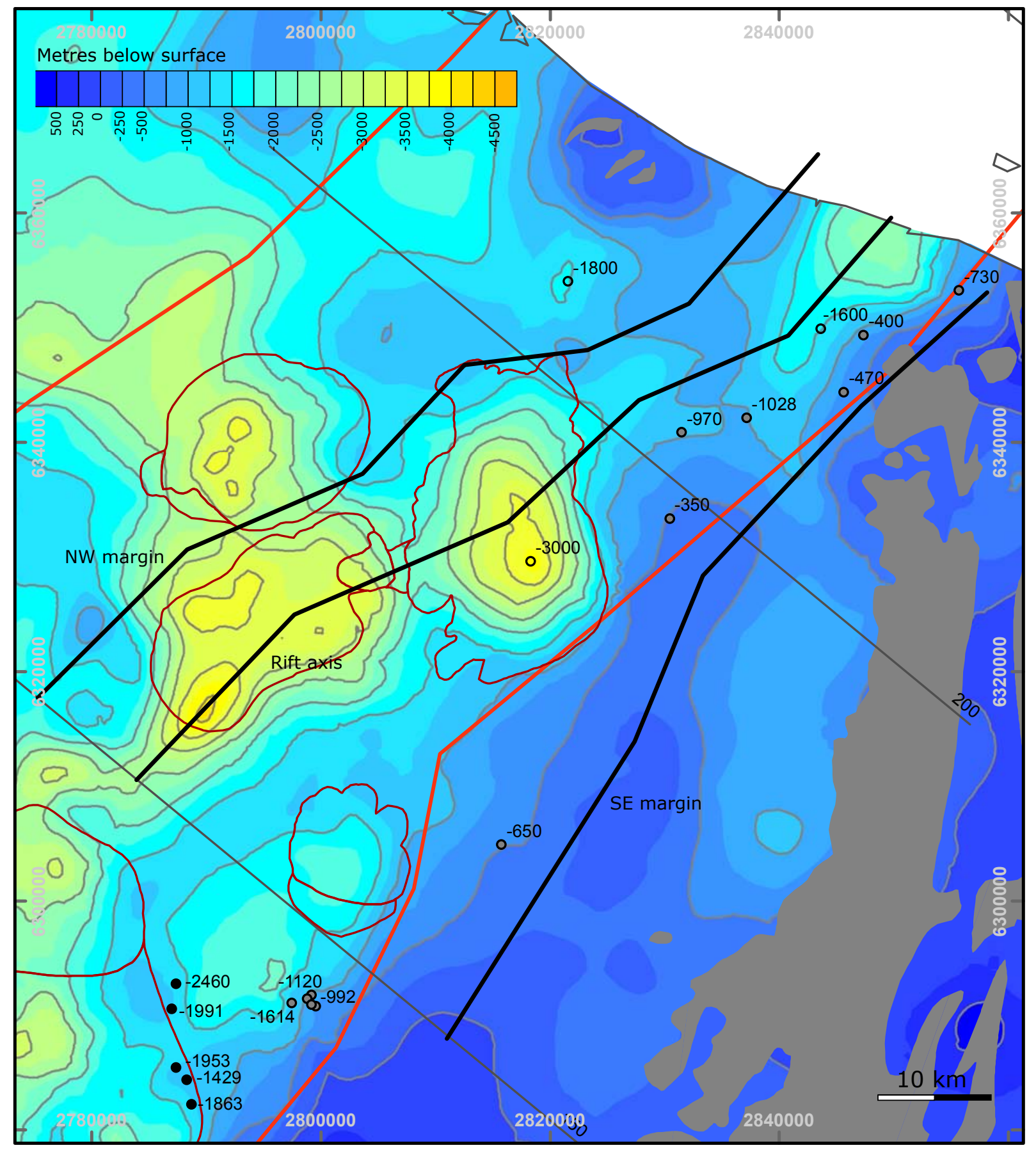

Fig. 3.9. Multi-1D basement model derived from residual gravity data (Fig. 2.3). Refer to Chapter 2 for derivation of minimum basement depth verses residual gravity and location of gravity stations. Basement depth and composition where known or inferred (filled circles, andesite and greywacke, black and grey repectively, open circles unknown) from independent published drill-hole, seismic refraction and reflection studies [Table 6.1 for references] and preliminary magnetotelluric data [Bibby unpublished data, 2007] are shown for comparison with minimum basement depth contours. Minimum basement depths from profile lines (black lines) on the rift margins relative to the axis provide information on the vertical displacement along-strike (dark grey lines). Vertical separations relative to the Taupo Rift axis are shown in Fig. 3.9. Mesozoic greywacke outcrop (grey shading) shown for reference. 

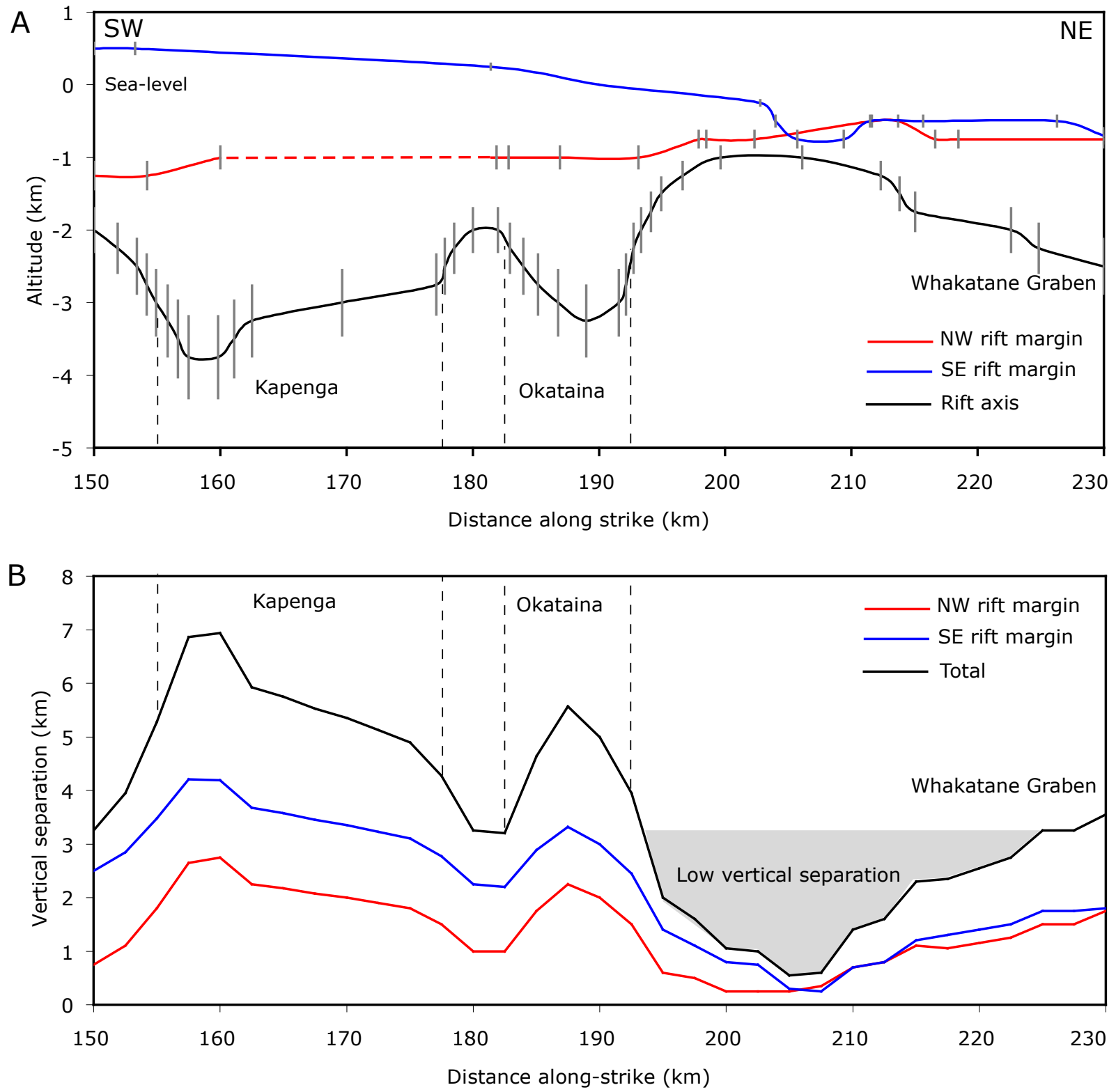

Fig. 3.10. Basement altitude and cumulative vertical separation profiles along-strike of the Taupo Rift. (A) Minimum basement altitude relative to sea-level along profiles detailed in Fig. 3.9 , typical errors estimated as $15 \%$ of depth (e.g. 300-400 $\mathrm{m}$ at $2 \mathrm{~km}$ depth). Dashed line across northwest margin represents restoration of margin after out of plane volcanic collapse has been removed. (B) Cumulative vertical separation across the active Taupo Rift. Southeast margin shows higher vertical displacement relative to the rift than northwest margin suggesting an asymmetry in the accumulation of displacement between northwest and southeast dipping faults. Area of low vertical separation discussed in the text. Calderas show localized increases in displacement which are interpreted to reflect gravitational collapse by repeated evacuation of large volumes of magma from depth. 
To the northeast of Okataina Caldera (distance 190-220 km) total vertical separations are $<1 \mathrm{~km}$, which is low compared to elsewhere along the rift (Fig. 3.10b). These low vertical separations primarily arise because the rift axis is high. If the rates of rift tectonic extension increase gradually to the northeast [e.g. Wallace et al., 2004; Nicol et al., 2007], then this region of low vertical separation indicates that, at this latitude, a significant component of the total extension since rift initiation accrued to the east (e.g. in the North Island Fault System) or west of the active rift (perhaps along the western boundary of the Central Volcanic Region).

The vertical separations in Fig. 3.10b have implications for which of the models presented in Fig. 3.1 are most applicable for the OVC. Fig. 3.10b most closely resembles Fig. 3.1b \& c where caldera collapse produces a local extension high which is above background tectonic values. Given the occurrence of dikes within the OVC and the vertical separation highs over the calderas Fig. 3.1c is the favoured extension model for the OVC. In this model regional extension remains approximately uniform across the volcanic centre and is accommodated by a combination of tectonic faulting and dike intrusion. Superimposed on this regional extension is a local extension (or fault displacement) arising from gravitational caldera collapse. As this extension is driven by withdrawal of magma from an underlying chamber it does not reflect regional tectonic extension.

\subsection{Conclusions}

Topographic, seismic reflection and gravity data have been used to measure fault displacements over time periods ranging from 60 to $220 \mathrm{ka}$. The resulting displacement rates along two fault zones together with historical accounts of the 1886 AD Tarawera eruption indicate neither dike intrusion nor caldera collapse contribute to fault displacements outside the volcanic complex. Rift faults that pass into the Okataina Caldera are utilised during its formation. Gravitational collapse during the 60 ka Rotoiti caldera forming eruption is interpreted to account for an increase in displacement of up to $50 \%$ in the Whirinaki Fault zone between the topographic margin and inner collapse boundary across the caldera margin. Within the OVC extension is accommodated by a combination of tectonic faulting, dike intrusion, and gravitational caldera collapse. A model is proposed for the OVC in which regional extension is approximately uniform across the volcanic complex and accommodated by a combination of tectonic faulting and dike intrusion. Gravitational caldera collapse in the OVC is locally superimposed on, and does not contribute to, regional extension. 


\section{CHAPTER FOUR}

RELATIONSHIPS BETWEEN FAULTING AND VOLCANISM IN THE OKATAINA VOLCANIC CENTRE 


\subsection{Introduction}

The location and trend of volcanism in active rifts commonly display close relationships with fault locations and orientations and/or the direction of crustal extension. These relations range from the alignment of volcanic vents and dike intrusions parallel with faulting to volcanism being focused at steps or bends in rifts where the rates of extension are elevated [e.g. Bacon, 1985; Mastin \& Pollard, 1988; Ferguson et al., 1994; Ring, 1994; Hayward \& Ebinger, 1996; Korme et al., 1997; Gundmundsson, 1998; Moore \& Kokelaar, 1998; Rowland \& Sibson, 2001; Acocella et al, 2002; Prejean et al., 2002; Bosworth et al., 2003; Corti et al., 2003; Kendall et al., 2005; Campbell et al., 2007; Keranen \& Klemperer, 2008]. In these volcanic rifts the geometry, style, and kinematics of faults develop in response to far field plate motions and are influenced by a number of factors including the orientation of the principal horizontal extension (PHE) direction and pre-existing tectonic fabric [e.g. Ring, 1994; Hayward \& Ebinger, 1996; Morley, 1999; Tommasi \& Vauchez, 2001; Acocella et al., 2002; Korme et al., 2004]. Relic crustal fabric, associated with prior tectonic event(s), can play a significant role in the geometric relationships between faulting and volcanism created during subsequent tectonic episodes [e.g. Morley, 1999; Acocella et al., 2002]. Relic basement fabric of Mesozoic age is widely observed throughout the North Island of New Zealand and controls the strike of many Cenozoic faults, including those that bound the eastern and western margins of the Okataina Caldera (Fig. 4.1) [Chapter 2]. Within the OVC the inferred north-south basement fabric trends at approximately $35-55^{\circ}$ to the strike of the main faults of the active rift and to the estimated trend of the PHE direction [Darby et al., 2000; Beavan \& Haines, 2001; Hurst et al., 2002].

This chapter investigates the PHE direction together with the geometric, spatial, and kinematic relationships between the Okataina Volcanic Centre (OVC) and Taupo Rift using a combination of new and existing geological and geophysical information. These data include surface faulting, new and existing gravity data sets [Chapter 2], published 1:50 000 and 1: 250000 geological maps [Nairn, 1989; Edbrooke, 2005; Leonard \& Begg, in prep.], historical seismicity [Anderson \& Webb, 1989; Robinson, 1989; Webb \& Anderson, 1998; Hurst et al., 2002; Hayes et al, 2004; Hurst et al., 2008; GEONET Earthquake catalogue], fault slip data [Beanland et al., 1989; Acocella et al., 2003; this study], and inversion of Global Positioning System (GPS) data [Beavan \& Haines, 2001; Beavan et al., 2007]. The available data help constrain the geometric and spatial relations between faulting and volcanism. The resulting analysis forms the basis 
of a model in which the location of volcanism is controlled by the intersection of two normal fault sets, one of which reactivates basement fabric and accommodates a component of right-lateral slip.

\subsection{Methods \& Data}

\subsubsection{Principal horizontal extension (PHE) direction}

Any estimation of the PHE direction for a region is dependent on the scale of observation. For example; a focal mechanism from an individual earthquake is a very local estimate over a given area (e.g. $10^{-1}-10^{1} \mathrm{~km}^{2}$ ), a fault slip vector is an integrated estimate over the area ruptured during an earthquake (e.g. $10^{-1}-10^{2} \mathrm{~km}^{2}$ ), stress inversions of a large number of earthquakes represent a more regional estimate of the PHE direction, the scale of which is dependent on the distribution of earthquakes used for each study (e.g. $10^{2}-10^{3} \mathrm{~km}^{2}$ ) and, at the longest length scale (e.g. $10^{3}-10^{4} \mathrm{~km}^{2}$ ), GPS observations provide an integrated PHE direction estimate from all processes that accommodate extension (e.g. distributed strain at grain-scale, extension fractures, fault slip and dike intrusion).

The orientation of the PHE direction has been estimated along the length of the Taupo Rift using local (focal mechanism, fault slip from outcrop and dike opening) and regional (earthquake stress inversion and GPS) extension direction indicators [Nairn \& Cole, 1981; Anderson \& Webb, 1989; Beanland et al., 1989; Robinson, 1989; Webb \& Anderson, 1998; Darby et al., 2000; Roland \& Sibson, 2001; Hurst et al., 2002; Acocella et al., 2003; Hayes et al., 2004; Beavan et al., 2007; Hurst et al; 2008]. Each of these data sets sample only parts of the onshore rift reliably and a more complete representation of the PHE direction along the strike of the Taupo Rift is achieved by combining all data [e.g. Acocella et al., 2003; Hayes et al., 2004; Hurst et al., 2008]. While the average PHE directions for different types of data in the same location do not differ more than $15-20^{\circ}$ (Table 4.1), these changes can be significant particularly when combined with minor modifications in the rift geometry. A $20^{\circ}$ difference in the orientation of the PHE direction could, for example, have implications for the rift style (i.e. orthogonal or oblique) [e.g. Rowland \& Sibson, 2001; Acocella et al., 2003], the kinematic relationships of intersecting fault sets [e.g. Mouslopoulou et al., 2007, 2008], and for previous kinematic models proposed to account for the location of the OVC [e.g. Spinks et al., 2005]. 


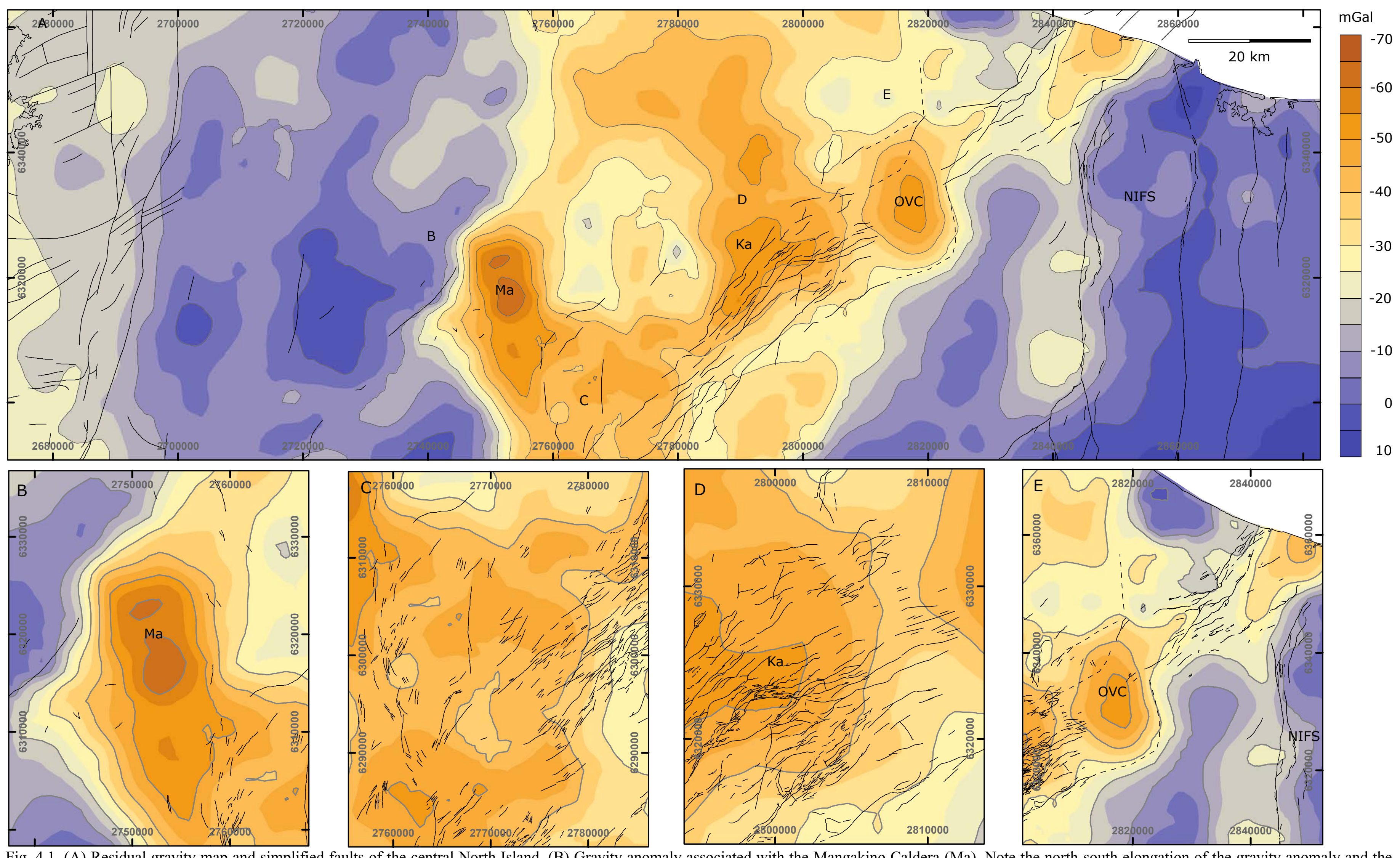

Fig. 4.1. (A) Residual gravity map and simplified faults of the central North Island. (B) Gravity anomaly associated with the Mangakino Caldera (Ma). Note the north-south elongation of the gravity anomaly and the northeast-southwest trending faults to either side of the maximum anomaly. (C) Active faults of the Whakamaru region showing the oblique intersection of north-south and northeast-southwest trends. The intersection angle between the two fault sets is $\sim 45^{\circ}$. (D) Faults adjacent to western boundary of OVC through the Kapenga Caldera (Ka) complex. Note minor north-south striking faults are sub-parallel to residual gravity contours, northeast-southwest faults average trend rotates clockwise (east) $20^{\circ}$ (also reflected in the residual gravity contours). (E) Eastern margin of the TVZ adjacent to the North Island Fault System (NIFS). Data: Chapter 2 details residual gravity reduction method, GNS Active Faults Database, Edbrook [2005] 


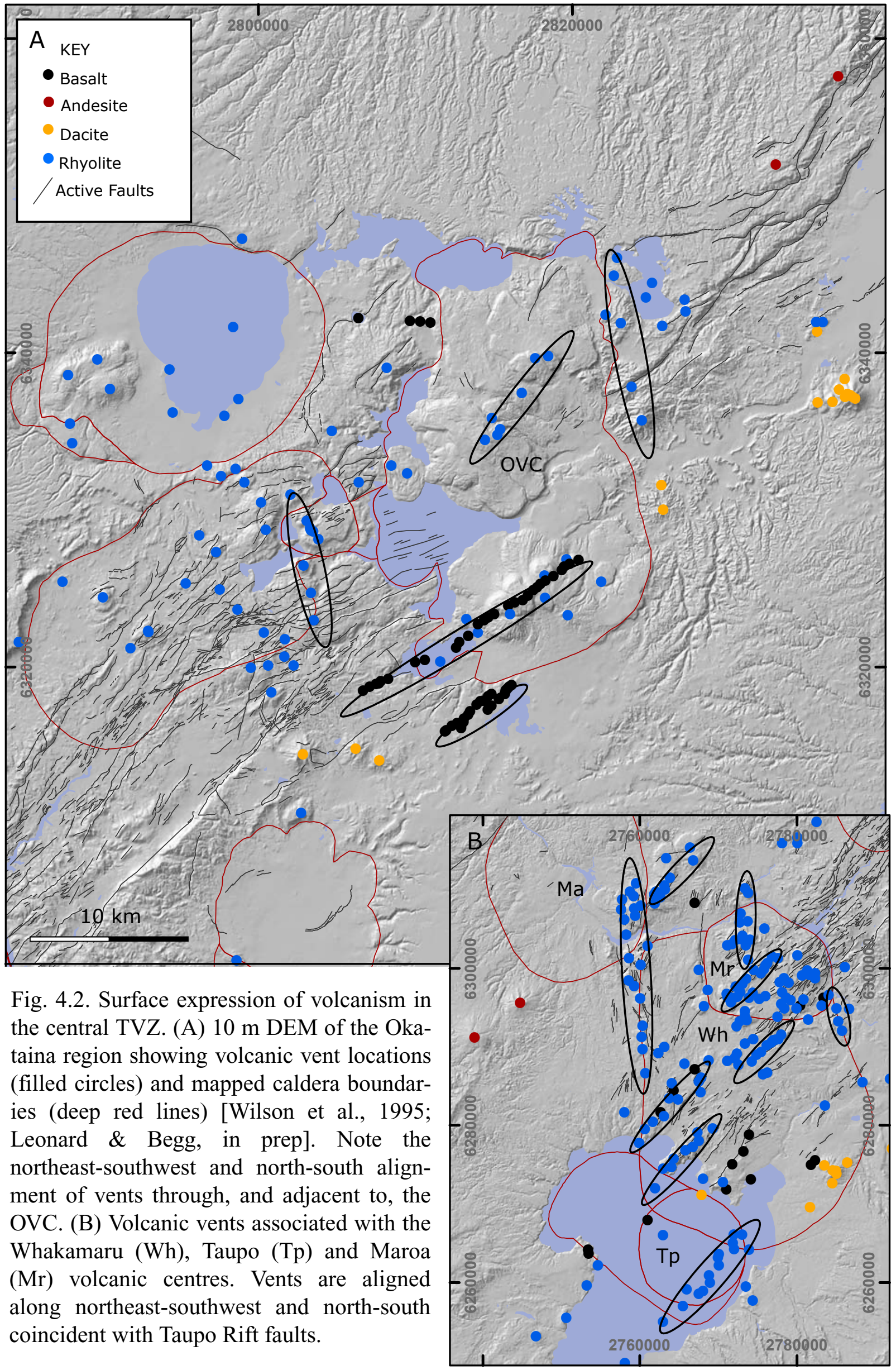




\subsubsection{Local PHE estimates}

Historical earthquakes provide an important record of crustal extension in the TVZ. Single earthquakes however provide little information about the ambient state of strain in any given volume of continental crust [Arnold \& Townend, 2007]. As T-axis orientations typically cluster within $20^{\circ}$ of horizontal focal mechanisms have been used here to determine a first-order estimate of the PHE direction for individual earthquakes (Fig. 4.3) [e.g. Robinson, 1989; Hurst et al., 2002; Hurst et al., 2008] (refer to references for specific details on the derivation of focal mechanism data). For the purposes of this study, T-axis orientations and inversion of $\mathrm{P}$ wave polarities are taken to be a close approximation of the 'true' orientation of PHE direction for each particular earthquake (or group of earthquakes) despite a non-vertical principle stress [Lund \& Townend, 2007]. Based on the difference between the calculated fault slip vector [Beanland et al., 1989] and the focal mechanism [Anderson \& Webb, 1989] for the $M_{L} 6.3$ Edgecumbe earthquake, an estimated uncertainty for the local PHE direction derived from focal mechanism data is $\pm 12^{\circ}$.

Fault slip vectors are determined from striations and grooves on fault surfaces [Acocella et al., 2003; this study], displaced landforms [Acocella et al., 2003; Mouslopoulou et al., 2007], and cultural features (e.g. fences) offset during the 1987 $M_{L} 6.3$ Edgecumbe normal faulting earthquake [Beanland et al., 1989]. Three fault slip measurements from a $188 \pm 3$ ka rhyolite dome adjacent to the western margin of the OVC were collected during this study to complement the Acocella et al. [2003] data set (Table 4.1).

The trends of slip vectors obtained from offset or abandoned streams channels trending at high angles to surface fault traces $\left(>70^{\circ}\right)$ typically have large uncertainties $\left(\leq \pm 28^{\circ}\right.$ ) which mainly arise due to the projection of piercing points up to the fault surface [Acocella et al., 2003]. By contrast, the trend and plunge of slip vectors measured using striations or grooves and offset cultural features are estimated to be \pm 5 $11^{\circ}$ [e.g. Beanland et al., 1989]. The Acocella et al. [2003] data set and three slip vectors measurements from this study were reduced to a PHE direction using the stereographic procedure of Marrett and Allmendinger [1990]. Here, the minimum strain axis (PHE direction) is at $45^{\circ}$ from the slip vector along the plane which passes through the pole to the fault and the slip vector. The resulting uncertainties on the trend of the PHE direction are approximately $\pm 10^{\circ}$, while the uncertainties for PHE direction using landform measurements are estimated as $\leq \pm 20^{\circ}$. 


\subsubsection{Regional PHE estimates}

A method for the estimation of the regional stress tensor by direct inversion of large numbers of earthquake $\mathrm{P}$ wave polarities has been used in a number of locations in the Taupo Rift [Hurst et al., 2002; Hayes et al., 2004; Hurst et al., 2008]. The total area from which $\mathrm{P}$ wave polarities are inverted vary between studies (e.g. $\sim 20 \mathrm{~km}^{2}$ [Hurst et al., 2008], $150 \mathrm{~km}^{2}$ [Hayes et al., 2004], and $\sim 1500 \mathrm{~km}^{2}$ [Hurst et al., 2002]) and therefore sample different length scales along the Taupo Rift. The Robinson \& McGinty [2000] inversion method used in these studies assumes that in a region of distributed faulting, small earthquakes (M 2-4) will preferentially occur on optimally oriented faults under the Coulomb failure criterion [Hayes et al., 2004]. The inversion method searches over a range of stress axes orientations defined by the greatest compressive stress $(\sigma 1)$ azimuth and plunge, and least compressive stress $(\sigma 3)$ azimuth. A best stress orientation is obtained by maximising the number of polarities from well-located events for which the observation and prediction are the same. The resulting PHE direction estimates are very similar to those derived from focal mechanisms [Hayes et al., 2004] and GPS [Beavan et al., 2007].

Inversion of velocity solutions derived from geodetic networks distributed across New Zealand provide present-day continuous horizontal velocity and strain rate fields throughout the North Island [Beavan \& Haines, 2001]. Throughout New Zealand, a first order distributed network of 29 GPS stations is supplemented with a further 333 stations in regional networks. The resulting horizontal velocity field utilises GPS stations observed at least twice (one year or more apart) between 1991 and 2007 [Beavan \& Haines, 2001; Beavan et al., 2007]. The inversion jointly minimizes the magnitudes of fitted strain rates and the misfit to the observed velocity data across a curvilinear grid allowing a high spatial resolution of strain rate and orientation of the PHE direction across regions with spatially dense GPS data. Along the length of the Taupo Rift (parallel to the plate boundary) PHE trend has been estimated from the GPS velocity model at five node points with 50-80 km spacing (Fig. 4.3). PHE at each of these nodes records deformation over length scales of $\sim 50 \mathrm{~km}$ centred on the node and enclosing the rift [Beavan \& Haines, 2001]. No errors have been published on the uncertainty of fit for the direction of PHE in the strain rate model of Beavan et al. [2007], however typical errors for vector orientations derived from other GPS studies in the area suggest an average of $\pm 11^{\circ}$ [Darby et al., 2000; Wallace et al., 2004]. 


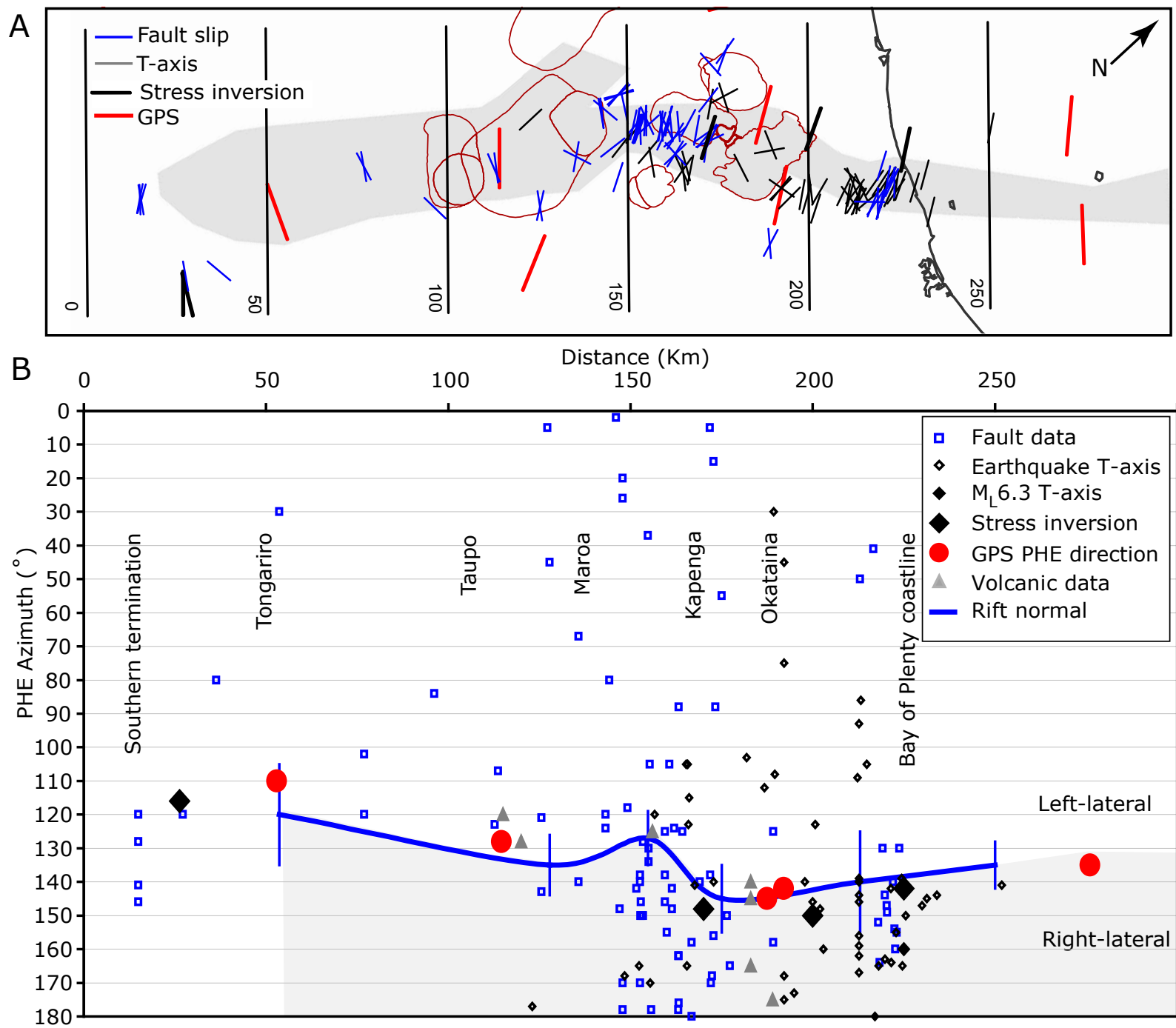

C

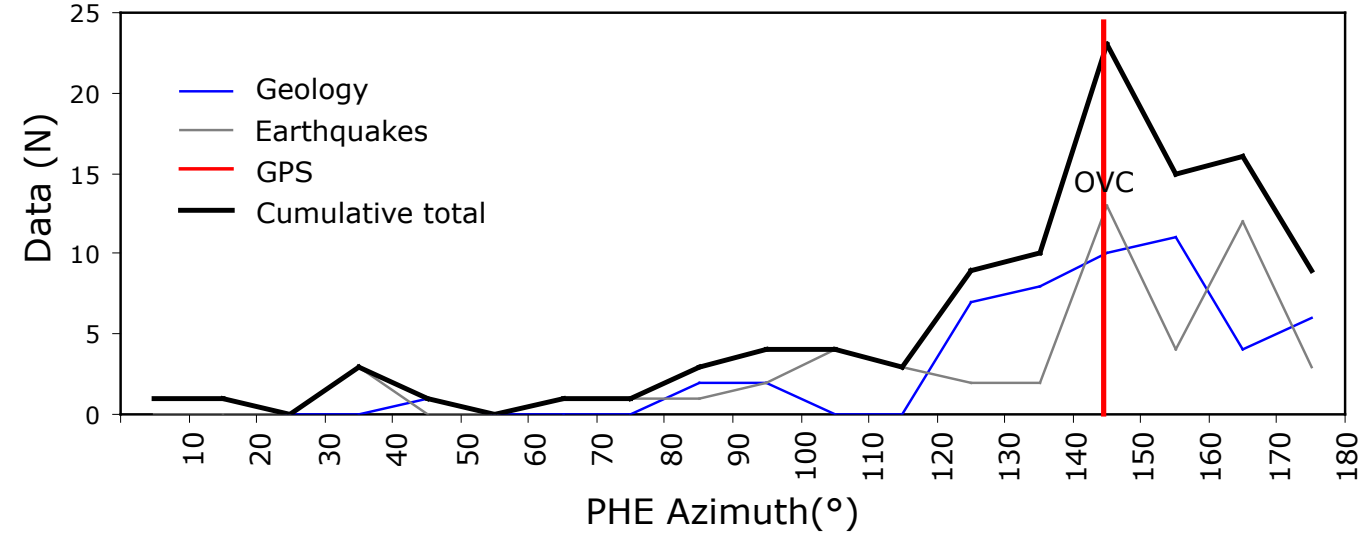

Fig. 4.3. Azimuths for principal horizontal extension (PHE) direction measurement along the Taupo Rift. (A) Local and regional PHE estimates from geological, earthquake, and GPS data for the Taupo Rift. Refer to Table 4.1 for data sources. (B) Plot of PHE azimuth verses distance along the rift from its southern termination. Blue line shows pure dip slip vectors for the average strike of Taupo Rift faults [Rowland \& Sibson, 2001; Lamarche et al., 2006]. Note the heterogeneous distribution of local PHE azimuth data (Fault slip and T-axis) and the general clustering clockwise of pure dip slip (i.e. small right lateral component). Regional PHE data show $30^{\circ}$ clockwise swing from south to north. (C) Frequency histogram for local PHE estimates for 40 $\mathrm{km}$ to the northeast and southwest of the OVC $(150-230 \mathrm{~km})$ indicating the modal $\sim 145^{\circ} \mathrm{PHE}$ direction for the OVC is consistent with regional GPS data of Beavan et al. [2007]. 


\begin{tabular}{|c|c|c|c|c|c|c|}
\hline $\begin{array}{c}\text { Distance } \\
\text { along } \\
\text { rift }(\mathrm{km})\end{array}$ & Location & Source & $\begin{array}{l}\text { Data } \\
\text { type }\end{array}$ & Number & Slip & Mean PHE \\
\hline 25 & $\mathrm{~W}$ & Hayes et al. [2004] & 5 & 564 & SS & $\sim 116^{\circ}$ \\
\hline 50 & $\mathrm{R}$ & Beavan et al. [2007] & 6 & 1 & - & $\sim 110^{\circ}$ \\
\hline 50 & $\mathrm{R}$ & Acocella et al. [2003] & 1,2 & 7 & $\mathrm{~N}$ & $130 \pm 7^{\circ}$ \\
\hline 115 & $\mathrm{~T}$ & Darby et al. [2000] & 6 & 2 & - & $125 \pm 18^{\circ}$ \\
\hline 115 & $\mathrm{~T}$ & Beavan et al. [2007] & 6 & 1 & - & $\sim 128^{\circ}$ \\
\hline 115 & $\mathrm{~T}$ & Acocella et al. [2003] & 1,2 & 8 & $\mathrm{~N}$ & $131 \pm 8^{\circ}$ \\
\hline 150 & NG & Acocella et al. [2003] & 1,2 & 43 & $\mathrm{~N}$ & $140 \pm 16^{\circ}$ \\
\hline 170 & OVC & Hurst et al. [2002] & 4 & 29 & $\mathrm{~N}, \mathrm{SS}$ & $\sim 148^{\circ}$ \\
\hline 170 & OVC & Hurst et al. [2002] & 5 & 628 & $\mathrm{~N}$ & $\sim 148^{\circ}$ \\
\hline 170 & OVC & This study & 1 & 3 & $\mathrm{~N}$ & $149 \pm 17^{\circ}$ \\
\hline 190 & OVC & Beavan et al. [2007] & 6 & 2 & - & $\sim 144^{\circ}$ \\
\hline 190 & OVC & Acocella et al. [2003] & 1,2 & 4 & $\mathrm{~N}$ & $161 \pm 15^{\circ}$ \\
\hline 200 & OVC & Hurst et al. [2008] & 5 & 516 & $\mathrm{~N}$ & $\sim 150^{\circ}$ \\
\hline 215 & WG & Robinson [1989] & 4 & 27 & $\mathrm{~N}, \mathrm{SS}$ & $144 \pm 22^{\circ}$ \\
\hline 220 & WG & Acocella et al. [2003] & 1,2 & 3 & $\mathrm{~N}$ & $143 \pm 3^{\circ}$ \\
\hline 220 & WG & Beanland et al. [1989] & 3 & 9 & $\mathrm{~N}$ & $150 \pm 11^{\circ}$ \\
\hline 225 & $\mathrm{M}$ & Hurst et al. [2008] & 5 & 465 & $\mathrm{~N}, \mathrm{SS}$ & $\sim 142^{\circ}$ \\
\hline 225 & WG & Anderson \& Webb [1989] & 4 & 1 & $\mathrm{~N}$ & $\sim 162^{\circ}$ \\
\hline 250 & M & Richardson [1989] & 4 & 1 & SS & $\sim 152^{\circ}$ \\
\hline 275 & BOP & Beavan et al. [2007] & 6 & 1 & - & $\sim 135^{\circ}$ \\
\hline 300 & BOP & Webb \&Anderson [1998] & 4 & 5 & $\mathrm{~N}$ & $140 \pm 8^{\circ}$ \\
\hline
\end{tabular}

Table 4.1. Extension direction data for the Taupo Rift. Data are presented from south to north with distance along the rift measured from the southern termination of the rift indicated in the left-hand column. Location: W, Waiouru; R, Ruapehu; T, Taupo; NG, Ngakuru Graben; OVC, Okataina Volcanic Centre; WG, Whakatane Graben; M, Matata; BOP, Bay of Plenty. Data type: 1, Fault plane striations and grooves; 2, displaced landforms; 3, offset cultural features; 4, T-axis average; 5, Stress inversion; 6, GPS. Slip: N, Normal faulting; SS, Strike-slip. See Fig. 4.3 for location of data. The single measurements of Anderson \& Webb [1989] and Richardson [1989] relate to the 1987 $\mathrm{M}_{\mathrm{L}} 6.3$ Edgecumbe and $1977 \mathrm{M}_{\mathrm{L}}$ 5.4 Matata earthquakes respectively. 


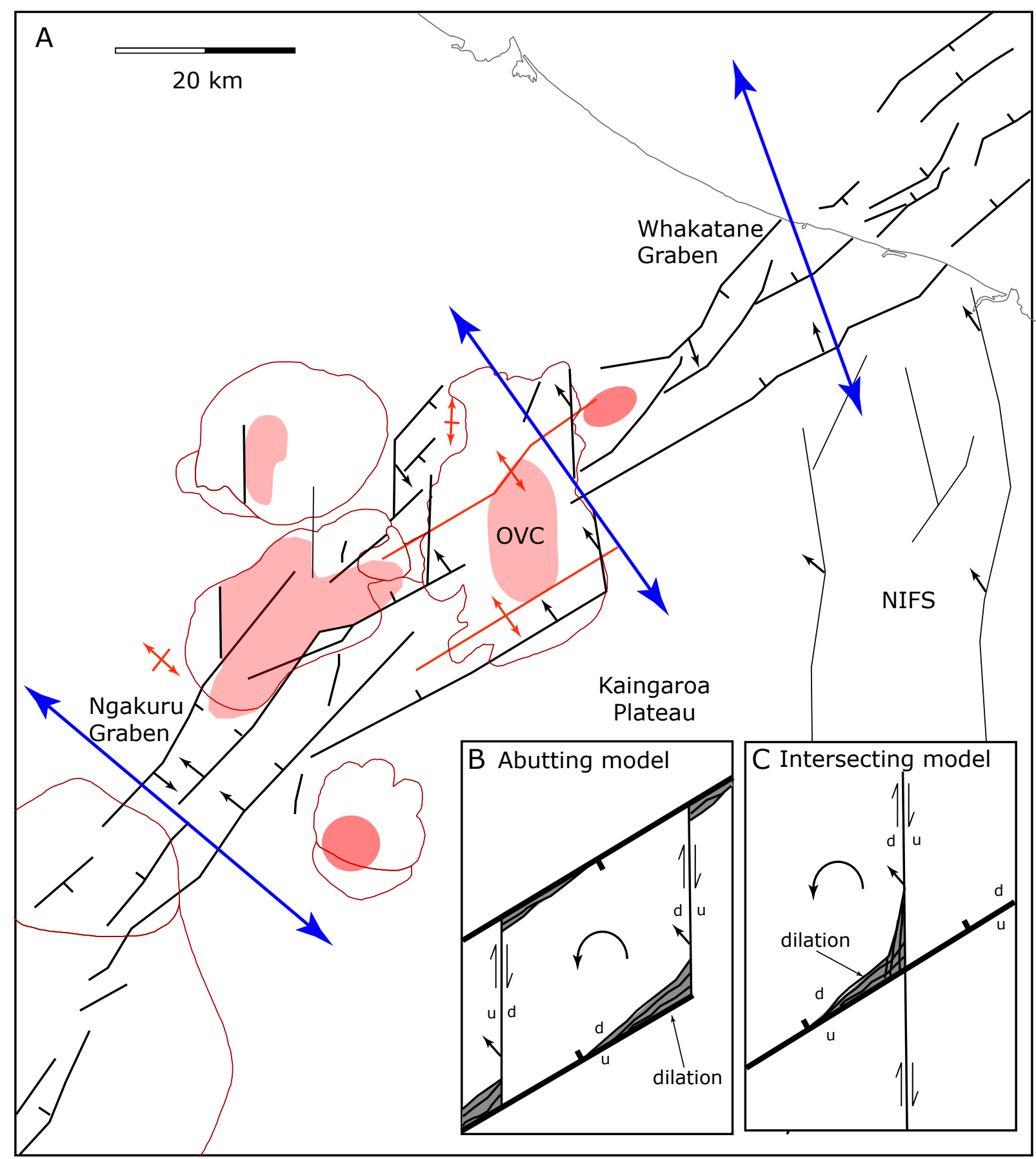

Fig. 4.4. Simplified map showing fault geometries and kinematics in Okataina area. Structural features of the OVC detailed in Chapter 2. (A) Regional extension directigns (blue arrows) in the Taupo Rift rotate by $\sim 20^{\circ}$ over $100 \mathrm{~km}$ along strike from the Ngakuru to Whakatane grabens (Fig. 4.3). Slip azimuths (small black arrows) for faults of the Taupo Rift and dextral North Island Fault System (NIFS) [Mouslopoulou et al., 2007] are shown along with the main inferred caldera collapse structures defined by gravity (red shading) [Chapter 2]. (B) Schematic diagram showing abutting fault sets and dilation (grey shading) at intersection arising from termination of oblique faults [after Kim et al., 2000]. (C) Schematic diagram showing intersecting fault sets and dilation (grey shading) at intersection arising from cross-cutting of preexisitng fault. Dilation zones in both models are areas of briitle faulting, increased slip and fluid flow approaching the intersection point between the fault sets [Watterson et al, 1998; Maerten et al. 1999; Sanderson \& Zhang, 1999]. 


\subsection{Relations between Faulting and Volcanism}

\subsubsection{Fault Geometries}

Northeast-southwest striking faults primarily define the geometry and location of the active rift [Cole, 1990; Rowland \& Sibson, 2001; Villamor \& Berryman, 2001], while subordinate north-south striking faults in the OVC are inferred to reactivate basement fabric [Chapter 2]. At the latitude of the OVC north-south striking faults are parallel to bedding and terrane boundaries outside the Central Volcanic Region [Chapter 2]. The subordinate north-south fault trend identified within, and adjacent to, the OVC is also observed further south, within, and bounding the Whakamaru Caldera (Fig. 4.1) [Rowland \& Sibson, 2001; Chapter 2]. In addition, residual gravity contours within several calderas delineate significant north-south trending anomalies (Fig. 4.2) (e.g. Mangakino, Whakamaru, and Taupo) [Davy \& Caldwell, 1998; Stagpoole \& Bibby, 1999; Chapter 2]. Evidence for two obliquely striking fault sets in the OVC is presented in Chapter 2 and summarised below in point form:

1) Northeast-southwest and north-south trending active fault traces.

2) Correlation of northeast-southwest trending surface fault traces outside the caldera with faults imaged beneath Lake Tarawera in seismic reflection lines.

3) Alignment of the main rift forming faults southwest of the OVC with steep gravity gradients along the northwest and southeast margins of the Okataina Caldera.

4) North-south trending segments of the eastern and western boundaries of the Okataina Caldera.

5) North-south trending cluster of earthquakes within and extending up to $15 \mathrm{~km}$ from the OVC.

As the rift enters the OVC it trends approximately $\sim 055-065^{\circ}$. The margins and axis of the rift step to the left (north) across the OVC by $\sim 10 \mathrm{~km}$. Fault mapping conducted as part of this thesis suggests that this step primarily occurs across the Okataina Caldera. The width of the step is defined by the north-south trending eastern margin of the caldera and north striking faults immediately west of the OVC (Fig. 4.1a). Both east and west margins of the step in the rift are inferred to be faults which utilise planes of weakness (e.g. stratigraphic boundaries or faults) in Mesozoic basement that existed prior to the formation of the active rift [Chapter 2]. These faults hard-link the rift across this left step [cf. Walsh \& Watterson, 1992]. 
Fig. 4.5. Structural models for the location of the OVC and its relation to the regional extension direction. (A) Left stepping rift model with reactivation of north striking basement fabric hardlinking the stepped rift [this study]. Refer to Fig. 4.3 for determination of PHE direction (grey arrows). (B) Right bending rift model with inferred extension direction [Acocella et al., 2003; Spinks et al., 2005]. Thick black lines show interpretation of the rift axis through the OVC. Residual gravity contours show the gravity lows associated with the rift and volcanic centres for $\mathrm{A}$ and $\mathrm{B}$. Inset boxes show simplified versions of each model.

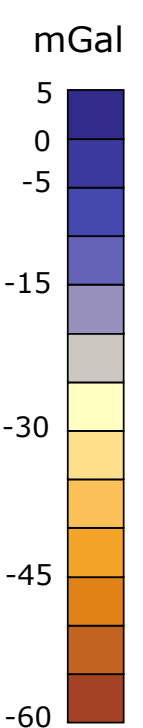

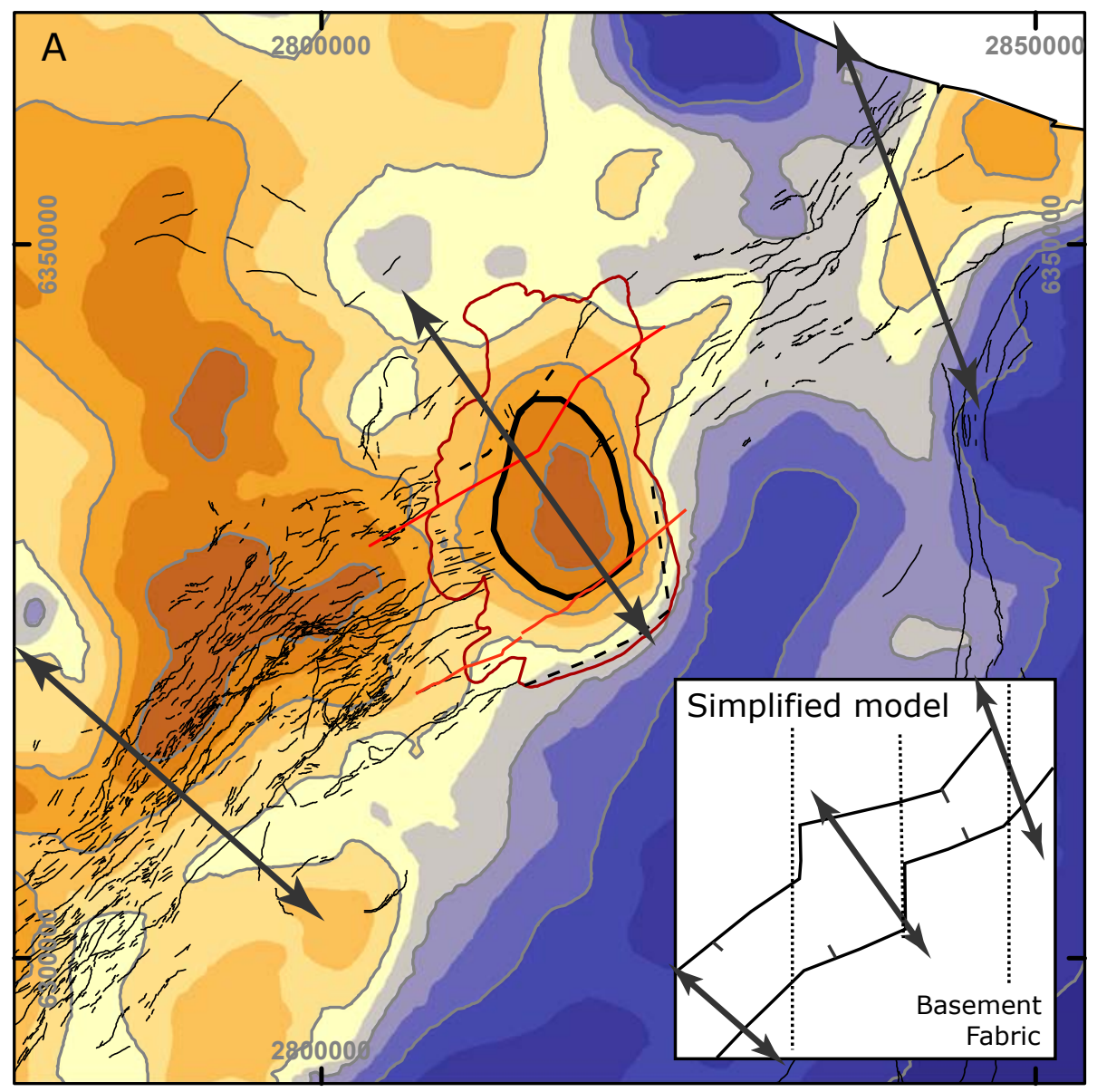

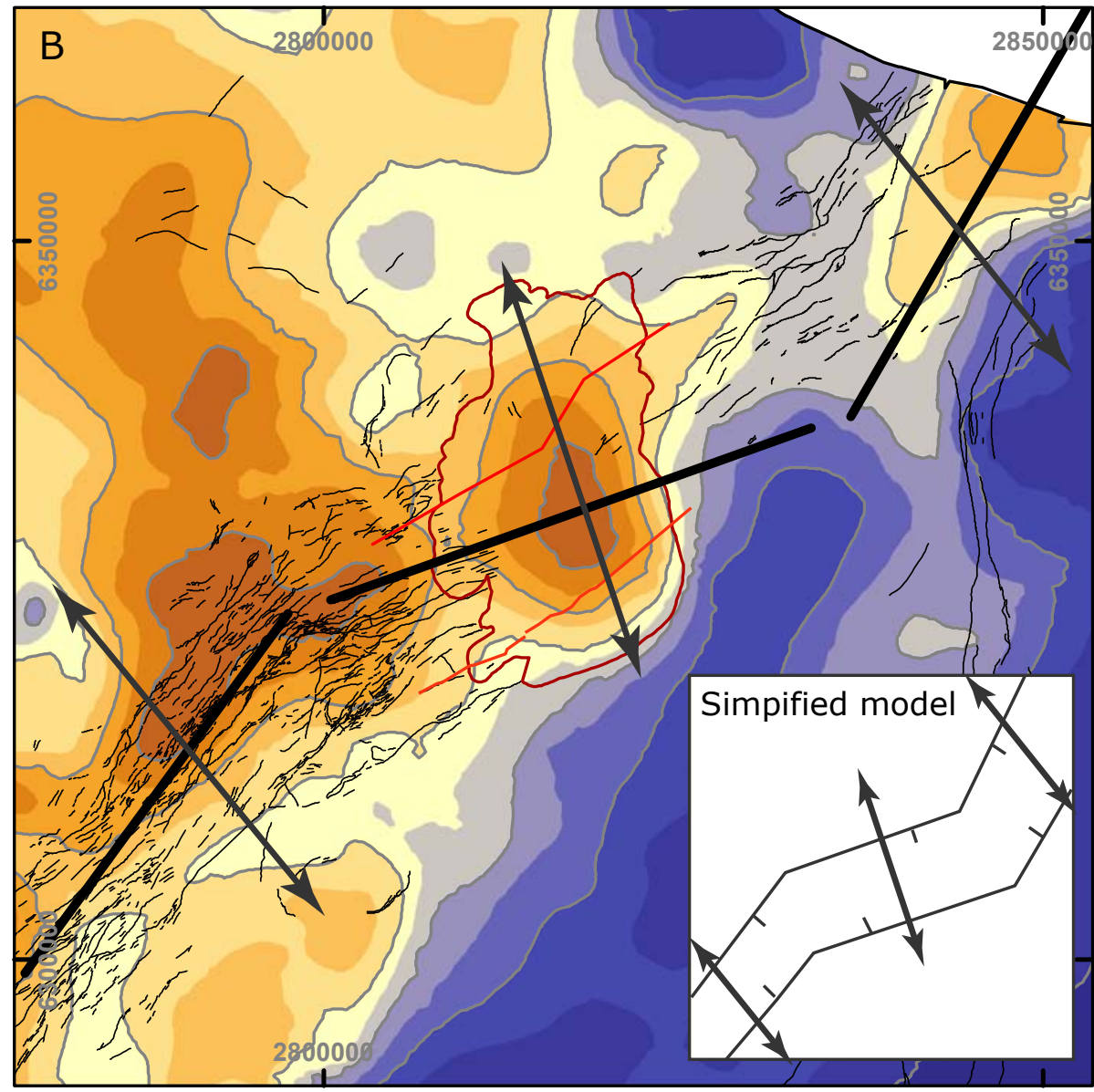


The left-stepping rift model across the OVC that is advocated here following reanalysis of fault and gravity data differs significantly from the east bending rift model of Acocella et al. [2003] (Fig. 4.6). The Acocella et al. [2003] model appears to be inconsistent with the available fault data. For example, the Acocella et al. [2003] model predicts faults immediately east of the central and southern OVC which are resolved neither in outcrop nor residual gravity. Therefore, the east bending rift model for the OVC should, in my view, be superseded by the left-stepping model.

\subsubsection{Principal horizontal extension direction}

The PHE directions for the different types of data are grouped according to the length scale they typically sample (i.e. fault slip and T-axes for local $\left(10^{-1}-10^{2} \mathrm{~km}^{2}\right)$ estimates and stress inversions and GPS for regional $\left(10^{2}-10^{4} \mathrm{~km}^{2}\right)$ estimates respectively). The estimated PHE directions along the length of the Taupo Rift show the density of data together with the variability of local PHE directions and their relations to fault strike change along the rift (Fig. 4.3). The southern Taupo Rift (0-50 km) have few data, however, the available information (both local and regional data) available suggests a PHE direction of $110-130^{\circ}$ (Fig. 4.3, Table 4.1). This PHE direction is approximately normal to the trend of the rift and indicates that faults are likely to be predominantly normal dip-slip and accommodate rift-orthogonal extension (Fig. 4.3) [Rowland \& Sibson, 2001]. Within the central Taupo Rift (50-150 km) local PHE direction estimates are variable, whereas regional estimates range from $125-140^{\circ}$ and require normal dip slip and possibly also a small $\left(<10-15^{\circ}\right)$ component of right-lateral slip (Fig. 4.3). A $20^{\circ}$ clockwise swing in the PHE direction and the average trend on rift faults is observed between Kapenga and Okataina volcanic centres (150-200 km). Therefore, the component of strike-slip may not change significantly along this section of the rift. In the northern Taupo Rift (200-230 km) data from measured fault displacement, the average T-axis orientation of 27 aftershock events associated with the $1987 \mathrm{M}_{\mathrm{L}} 6.3$ Edgecumbe earthquake and a stress inversion from a 2005 Matata earthquake sequence indicate a PHE direction of $142-162^{\circ}$ (Table 4.1). The individual fault plane solution for Edgecumbe earthquake is near pure-dip slip with a PHE direction of $162^{\circ}$, however like the central section of the rift, minor right-lateral slip is observed across the rift in the Whakatane region [Webb \& Anderson, 1989].

Along the length of the Taupo Rift the predominance of orthogonal rifting and dip-slip faulting is supported by GPS data (Fig. 4.4a). Collectively the strain data suggest that the PHE direction swings $\sim 30^{\circ}$ clockwise in trend from south to north along 
the rift. This swing in PHE trend suggests that, on average, a small component of rightlateral slip (i.e. with slip vectors up to $10-15^{\circ}$ from pure dip slip) is possible, particularly in the central and northern parts of the rift. However, the precise amount of strike slip cannot be quantified given the small number of data and the uncertainties and range of slip vector measurements on individual faults.

The regional PHE direction across the OVC typically ranges from 144 to $150^{\circ}$ (Fig. 4.3, Table 4.1). The frequency histogram derived from local PHE directions indicates a modal PHE azimuth across the OVC region of $\sim 145^{\circ}$ and is consistent with the regional estimate (Fig. 4.3c). This azimuth is perpendicular to the average $055 \pm 10^{\circ}$ strike of the rift faults and linear vent zones associated with the OVC and oblique relative to the long-axis of the caldera $\left(\alpha 35^{\circ}\right)$ (refer Fig. 2.1) [e.g. Rowland \& Sibson, 2001; Nairn, 2002; Acocella et al., 2003; Beavan et al., 2007]. However, a left-stepping en echelon array of basaltic dikes formed during the 1886 AD Tarawera eruption strike $15-20^{\circ}$ clockwise of the average fault strike and, if the dikes formed during pure dilation, may indicate a component of right-lateral slip [Nairn \& Cole, 1981]. If present, the component of right-lateral slip on approximately northeast striking faults is likely to be small and these faults are dip slip. If the $\sim 145^{\circ}$ PHE azimuth also applies to north striking faults in the OVC then these faults would accrue approximately equal components of normal and right-lateral slip.

Scarps along north-south striking fault traces indicate that these carry a component of normal slip. However, piercing points, which are required to measure strike-slip, have not yet been identified on these fault traces. Fault-slip data from the northern and eastern margins of the Whakamaru Caldera support oblique right-lateral motion on north-south fault planes [Acocella et al., 2003]. Relocated events from the 1998 Haroharo, and 2004 Rotoehu, earthquake sequence trend along both northeastsouthwest and north-south lineations within, and adjacent to, the Okataina Caldera at depths of 5-9 km [Hurst et al., 2008]. Support for some strike-slip on near vertical north-south striking faults (on the northern margin, and up to $30 \mathrm{~km}$ northeast of the Okataina Caldera) comes from the 2004 Rotoehu earthquake sequence, from strike-slip and oblique-slip focal mechanisms associated with the $1977 \mathrm{M}_{\mathrm{L}} 5.4$ Matata earthquake, from aftershocks of the $1987 \mathrm{M}_{\mathrm{L}} 6.3$ Edgecumbe earthquake, and from the 2005 Matata earthquake sequence [Richardson, 1989; Robinson, 1989; Hurst et al., 2008]. The predominance of normal faulting ( \pm a strike-slip component) on northeast-southwest and north-south trends suggests the magnitude of the least principal $(\sigma 3)$ and intermediate $(\sigma 2)$ stress are similar in this region [Robinson, 1989]. 
Using double-difference earthquake location methods, Prejean et al. [2002] have identified oblique-slip faults within the Long Valley Caldera that have no mapped surface expression and may be analogous to the north-south striking faults in the OVC. Oblique slip faults in the Long Valley Caldera play an important role in the kinematics of the caldera at depths of 6-9 km and help to accommodate extension across a $20 \mathrm{~km}$ step in the Sierra Nevada bounding faults.

\subsection{Faulting and linear volcanic vent locations}

Many silicic volcanic fields can be grouped into one of three main categories: (i) those with vent locations controlled by regional tectonics, (ii) those associated with sizeable crustal magma bodies that locally influence the location of vent formation (i.e. magmatically controlled), and (iii) those that are transitional between (i) and (ii) [Bacon, 1985]. Linear arrays of coeval volcanic vents, both basaltic and rhyolitic, are fed by dikes which are perpendicular to the PHE direction in a homogeneous medium [Bacon, 1985].

Linear volcanic vents in categories (i) and (iii) are spatially coincident with faults in the Kenyan and Ethiopian Rifts, Cordon Caulle in southern Chile, the Coso volcanic field in eastern California, South Sister in the central Oregon Cascades, and the Inyo-Mono domes adjacent to the Long Valley Caldera [Bacon, 1985; Mastin \& Pollard, 1988; Korme et al., 1997; Acocella et al., 2002; Bosworth et al., 2003]. Similar spatial relations between faulting and volcanism are also observed in the Southern Havre Trough (to the north of the TVZ), where linear volcanic vents/dikes are generally parallel to, and spatially coincident with, rift faults [Campbell et al., 2007].

Rhyolitic vents within the TVZ are predominantly aligned northeast-southwest parallel to the strike of normal faults (Fig. 4.2) [Rowland \& Sibson, 2001; Acocella et al., 2003; Leonard \& Begg, in prep]. This alignment is particularly clear within and immediately north of Lake Taupo (Fig. 4.2b). Aligned vents have been observed parallel to both northeast-southwest and north-south fault sets associated with the Okataina region. Through the OVC, for example, the Tarawera and Haroharo linear vent zones are parallel to northeast striking faults and situated vertically above the inferred intersection of the caldera floor with rift faults along the southeast and northwest caldera margins (Fig. 2.7). Vent alignments are also observed in north-south orientation adjacent to the OVC along the eastern margin of the Kapenga Caldera, along the eastern margin of the Okataina Caldera and further south along the western margin of the Whakamaru Caldera (Fig. 4.2a \& b). Magnetic anomalies associated with the 
Taupo Caldera and the White Island Anomaly Field (at the northern extremity of the TVZ) also indicate north-south trending magma emplacement aligned for distances of 10-20 km [Wright, 1992; Davy \& Caldwell, 1998].

The parallelism of faulting and the volcanic linear vent zones suggests that the orientations and formation of these features is interrelated. In the OVC, for example, the location of the Haroharo and Tarawera vents above faults interpreted from gravity data [Chapter 2] is consistent with the suggestion that magma passed up the faults within basement [Wood, 2001]. As the vents are vertically above the inferred intersection of the caldera floor and main rift faults it seems unlikely that magma migrates to the ground surface along faults. Instead, within relatively unconsolidated caldera infill material the magma diverges from the dipping fault zones and rises vertically to the ground surface. The vertical rise of magma through caldera infill suggests that the buoyancy/driving pressure of the rising magma exceeds the tensile strength of these rocks (e.g. Fig. 2.7). Movement of magma along faults has been widely postulated in the TVZ [e.g. Cole, 1990; Wilson et al., 1995; Rowland \& Sibson; 2001; Heiss et al., 2007] and is consistent with intrusion of dikes into tectonically controlled fault zones [Bacon, 1985]. The presence of linear vents in the TVZ parallel to both north-south and northeast-southwest faults would suggest that both sets may be acting as conduits for magma migration. In such a model, faulting would predate the volcanism creating zones of weakness between the ductile lower crust $(>8-9 \mathrm{~km})$ and the ground surface. Therefore, faults may facilitate the vertical ascent of magma and subsequent volcanic eruption [e.g. Bacon, 1985; Moore \& Kokelaar, 1998; Canon-Tapia \& Walker, 2004].

The predominantly fault-controlled geometry of many TVZ calderas [Chapter 2] and the potential increase in fluid flow at the intersections of the two oblique fault sets [this chapter] may also have implications for the location of geothermal activity in the TVZ. Wood [1995] argues that while caldera boundaries are often speculative, 15 out of 20 geothermal systems considered occur on or next to a caldera margin where there is enhanced deep permeability (Fig. 4.6). However, Bibby et al. [1995] argue that while calderas comprise $\sim 55 \%$ of the central TVZ and contain $59 \%$ of the high-heat geothermal systems, the link between these two systems is no more than expected on a random basis and suggest both are a consequence of the extremely high heat-flow though the TVZ. 

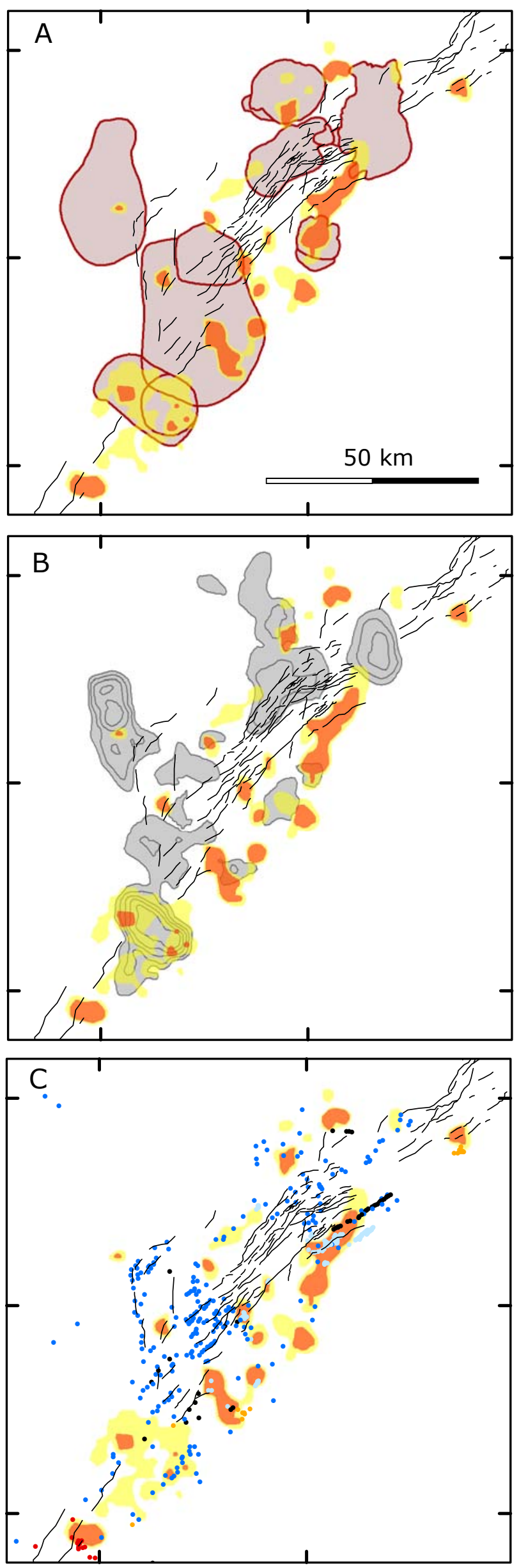

Fig. 4.6. Spatial relations between TVZ calderas and geothermal activity. (A) Mapped caldera boundaries of Wilson et al. [1995] (deep red shading) and low resistivity areas of Bibby et al. [1995] red and yellow shading). $59 \%$ of high-heat flow geothermal systems are spatially associated with topographic caldera boundaries [Wood, 1995] (B) Minimum gravity anomalies (grey shading) associated with TVZ calderas [Chapter 2] and geothermal activity. Note the spatial correlation between the gravity defined inner caldera structures and point source geothermal activity. The fault intersection model [this study] where zones of high permeability associated with the intersection of northeast-southwest and north-south faults could account for the limited spatial distribution of fluid systems. (C) TVZ volcanic vents [Leonard \& Begg, in prep] and geothermal activity. There appears to be no significant correlation between volcanic vent location and areas of high heat flow. Refer to Fig. 4.2 for vent composition. 


\subsection{Faulting-volcanism model for the OVC}

The calderas of the TVZ form discrete locations of volcanism that are stable for time intervals > 500 kyr (e.g. Mangakino [Wilson et al., 1995] and Okataina [Leonard unpublished data, 2007]) and are typically regions of high heat flow (Fig. 4.6) [e.g. Wood, 1995]. Ongoing high heat flow and volcanic activity in the OVC appears to be influenced by a combination of tectonic and magmatic processes [Chapter 3]. The relations between rift faults and OVC volcanism, and in particular, the inferred role of reactivated basement structure, differ from previous volcano-tectonic models proposed by Acocella et al. [2003] and Spinks et al. [2005]. Acocella et al. [2003] and Spinks et al. [2005] models require that the OVC is located at an eastward (clockwise) bend in the rift (Fig. 4.5). This rift geometry would permit northeast striking faults in the OVC to accommodate pure dip-slip in the approximate direction of caldera elongation. Spinks et al. [2005] argue that pure dip-slip in the OVC locally increases extension of the crust which focuses volcanism at this location. However, the absence of a clear eastward bend in the rift and the left step of the active faults through the OVC (section 4.3.1) require some component of right-lateral motion on north-south faults within the volcanic centre. This calls into question the pure dip slip model proposed by Spinks et al. [2005]. In the model presented here the OVC is located at a left step in the active rift which is hard-linked via north-south striking faults (Fig. 2.10a). A similar (but soft linked) northward-step in the active rift is inferred through the Whakamaru Caldera [Rowland \& Sibson, 2001].

Based on the available data, a model is proposed in which volcanism within the OVC has been focused at the intersections of synchronous north-south and northeastsouthwest striking active faults. Northeast-southwest faults are the dominant set, accommodating normal dip-slip, and have lengths up to $28 \mathrm{~km}$ [Villamor \& Berryman, 2001; Rowland \& Sibson, 2001; Nicol et al., 2006]. By contrast, the subordinate northsouth faults are inferred to accommodate oblique slip comprising approximately equal components of normal and right-lateral slip along short $(<10 \mathrm{~km})$ discontinuous traces. Therefore, a fault model in which north-south faults abut the main northeast-southwest striking rift faults is consistent with the data (Fig. 4.4b).

Abutting intersecting fault geometries and a significant component of strike slip on terminating north-south faults requires high displacement gradients approaching the tips of these faults and, as a consequence, would produce dilation proximal to the intersection coupled with anticlockwise vertical axis rotation of the fault-bound blocks 
(Fig. 4.4b) [Maerten et al., 1999; Sanderson \& Zhang, 1999; Kim et al., 2000]. Analysis of small-scale outcrop examples of synchronous abutting strike-slip fault sets confirms that such intersections can localise fluid flow and vein formation [Sanderson \& Zhang, 1999]. At a crustal scale these fault intersections may create zones of dilation and distributed brittle deformation that are comparatively weak providing potential pathways through which magma ascends [e.g. Bacon, 1985; Kim et al., 2000; Corti et al., 2003; Canon-Tapia \& Walker, 2004]. An analogue for this model may be the Waihi Caldera $90 \mathrm{~km}$ north-northeast of the OVC [Smith et al., 2006]. Here, caldera collapse is focussed at the intersection of obliquely intersecting northeast-southwest and northsouth regional faults [Smith et al., 2006]. Although not specifically discussed, similar zones of high brittle deformation would be expected at the intersections of cross-cutting fault sets (Fig. 4.4c) [e.g. Watterson et al., 1998] and could also promote the localisation of magma chambers in, and the rise of magma through, the brittle crust [Bacon, 1985, Sanderson \& Zhang, 1999]. The intersecting fault hypothesis for the localisation of volcanism is consistent with the suggestion that magma migrates along faults (section 4.4). This model is also consistent with the spatial distribution of volcanism throughout the TVZ, which is generally clustered in point sources as opposed forming overlapping en echelon magmatic segments such as those observed in Iceland and Afar [Gudmundsson, 2000; Ebinger \& Casey, 2001].

\subsection{Discussion}

\subsubsection{Magmatic verses fault TVZ extension}

A key question for the TVZ is: to what extent has extension of the crust been accommodated by dike intrusion? Within the OVC the presence of dikes and linear vent systems, which parallel the main faults and appear to have accommodated dilation approximately parallel to the PHE direction, provides evidence that some extension in the OVC accrues during dike intrusion. As faults can be traced into the OVC (mainly using seismic reflection and gravity data) it is argued that within $\sim 3 \mathrm{~km}$ of the ground surface some of the regional extension in this volcanic centre was also accommodated by faulting. Whether faulting in the upper crust of the OVC has been driven by dike intrusion at depth cannot be determined. Thus, while it seems unlikely that during the last 22 kyr (i.e. the time period for which dike intrusion has been documented; Nairn, 2002) all extension in the brittle crust of the OVC was accommodated by faulting, the 
possibility that at depths of 5-9 $\mathrm{km}$ all extension accumulated during dike intrusion cannot be discounted.

\begin{tabular}{|c|c|c|c|c|c|}
\hline Rift segment & $\begin{array}{c}\text { Moho } \\
\text { Depth } \\
(\mathrm{km})\end{array}$ & $\begin{array}{c}\text { Extension } \\
\text { rate } \\
(\mathrm{mm} / \mathrm{yr})\end{array}$ & $\begin{array}{c}\text { Normalized } \\
\text { strain rate (x } \\
\left.10^{15} / \mathrm{s}\right)\end{array}$ & $\begin{array}{c}\text { Quaternary- } \\
\text { recent basin } \\
\text { width }(\mathrm{km})\end{array}$ & $\begin{array}{c}\text { Maximum } \\
\text { fault length } \\
(\mathrm{km})\end{array}$ \\
\hline $\begin{array}{c}\text { Southern } \\
\text { MER }\end{array}$ & $\sim 30$ & $3-8$ & $1.46-8.45$ & $30-65$ & $\sim 50$ \\
\hline Central MER & $32^{(8)}$ & $3-8$ & $1.19-3.90$ & $65-80$ & $\sim 50$ \\
\hline $\begin{array}{c}\text { Northern } \\
\text { MER }\end{array}$ & $28 \pm 2$ & $3-8$ & $1.90-8.45$ & $30-50$ & $\sim 50$ \\
\hline $\begin{array}{c}\text { Central } \\
\text { Taupo Rift }\end{array}$ & $15-20^{(2)}$ & $9 \pm 3^{(3)}$ & $9.51-21.8$ & $15-40$ & $28^{(4)}$ \\
\hline $\begin{array}{c}\text { Southern } \\
\text { Afar }\end{array}$ & $26 \pm 1$ & $3-8$ & $6.34-16.9$ & $\sim 15$ & $\sim 30$ \\
\hline $\begin{array}{c}\text { Eastern- } \\
\text { central Afar }\end{array}$ & $25 \pm 2$ & $15-18$ & $39.6-47.5$ & $\sim 12$ & $\sim 30$ \\
\hline $\begin{array}{c}\text { Northern } \\
\text { Afar }\end{array}$ & $16 \pm 3$ & $18-22$ & $190-232$ & $\sim 3$ & $\sim 10$ \\
\hline $\begin{array}{c}\text { Iceland } \\
10-15^{(5)}\end{array}$ & $18^{(6)}$ & $28.5-114$ & $5-20^{(6)}$ & $\sim 10^{(7)}$ \\
\hline $\begin{array}{c}\text { Mid-Atlantic } \\
\text { Ridge }\end{array}$ & $8 \pm 2$ & 24 & 38 & $\sim 20$ & $\sim 20$ \\
\hline
\end{tabular}

Table 4.2: Variation in rift crustal thicknesses and faulting for increasing extensional strain. Data: Main Ethiopian Rift (MER) and Afar from Hayward \& Ebinger [1996] and references therein, (1) Harrison \& White [2006], (2) Stratford \& Stern [2006], (3) Darby et al. [2000], (4) Villamor \& Berryman [2001], (5) Bjornsson et al. [2005], (6)

Gudmundsson [2000], (7) Forslund \& Gudmundsson, [1992], (8) Keranen \& Klemperer, [2008].

Far field plate motion and pre-existing crustal fabric largely control the along axis segmentation of continental rifts where extension is primarily accommodated by faults. In contrast, asthenospheric processes strongly influence the along axis segmentation of mid-ocean ridges [Hayward \& Ebinger, 1996]. The spatial patterns of crustal structure across the spectrum of faulted to magma-assisted rifts (e.g. Fig. 1.1) shows a systematic reduction in crustal thickness and Quaternary-Recent fault length with increasing strain rate (Table 4.2). The data presented in Table 4.2 are consistent with the view that higher strain rates produce greater crustal thinning [e.g. Hayward \& Ebinger, 1996; Keranen \& Klemperer, 2008]. The thickness of the crust in turn appears to influence maximum fault lengths, which are typically a factor of 1-2 of the crustal thickness (Table 4.2). Volcanic rift zones are typically characterised by abundant subparallel normal faults, tensile cracks, graben subsidence, and overlapping en echelon 
magmatic segments with dike intrusion accommodating $>80 \%$ of the horizontal extension [e.g. Rubin \& Pollard 1988; Ebinger \& Casey, 2001].

Across the range of crustal thicknesses and maximum fault lengths associated with increasing strain rate, the Taupo Rift shows similarities with southern Afar, a transitional zone between continental rifting in the northern Main Ethiopian Rift and magmatic spreading in Northern Afar [Wright et al., 2006]. Outside the volcanic centres in the TVZ the extent to which crustal extension has been accommodated by dike intrusion is presently a point of debate [e.g. Nicol et al. 2006; Rowland et al., 2007]. In contrast to rifting in Afar, the Taupo Rift shows no evidence for overlapping en echelon magmatic segments along the length of the rift as evidenced by magnetic and geothermal activity [e.g. Bibby et al., 1995; Wilson et al., 1995].

The interpretation that faults (and not dike intrusion) primarily accommodate extension at depth (i.e. 5-9 km) in the Taupo Rift is supported by the timing and distribution of fault displacements across the region. Nicol et al. [2006] show fault displacement rates within the rift are highly variable on short timescales ( $<18 \mathrm{ka}$ ) whereas at longer timescales ( $\geq 60 \mathrm{ka}$ ) and increasing fault size, displacement rates become uniform when aggregated across the entire rift. Slip events on these faults appear not to be synchronous, while displacement in these events is, on average, about 1 m [Nicol unpublished data, 2008]. Volcanic rifts typically have symmetrical synchronous slip of 1-2 $\mathrm{m}$ on individual faults either side of 2-3 km wide zone centred on the dike intrusion [Rubin \& Pollard, 1988; Wright et al., 2006]. The lack of synchronicity and the small displacement during slip events suggests that, if dike intrusion at depth $(<10 \mathrm{~km})$ is occurring along the TVZ the dikes would be thin (e.g. $<$ $1 \mathrm{~m}$ wide), located at the base of (or intruded into) faults and form often (e.g. every 100 years or less). Thus, if dikes have formed outside the volcanic centres of the TVZ, they affect the faults in a manner that has not been previously described in magma-assisted rift systems [e.g. Rubin \& Pollard, 1988; Wright et al., 2006]. Given the paucity of data to support dike intrusion outside of the volcanic centres, the hypothesis that in these areas faults do not result from dike intrusion and are driven by regional tectonics is favoured.

Comparison of regional magnetotelluric profiles across the TVZ and Iceland further supports the view that Taupo Rifting is not magmatically assisted outside the main volcanic centres (Fig. 1.1). In a magma-assisted rift system such as Iceland, the upper crust of the axial rift zone is $10-15 \mathrm{~km}$ thick and comprises mainly dike intrusions [Bjornsson et al., 2005]. 

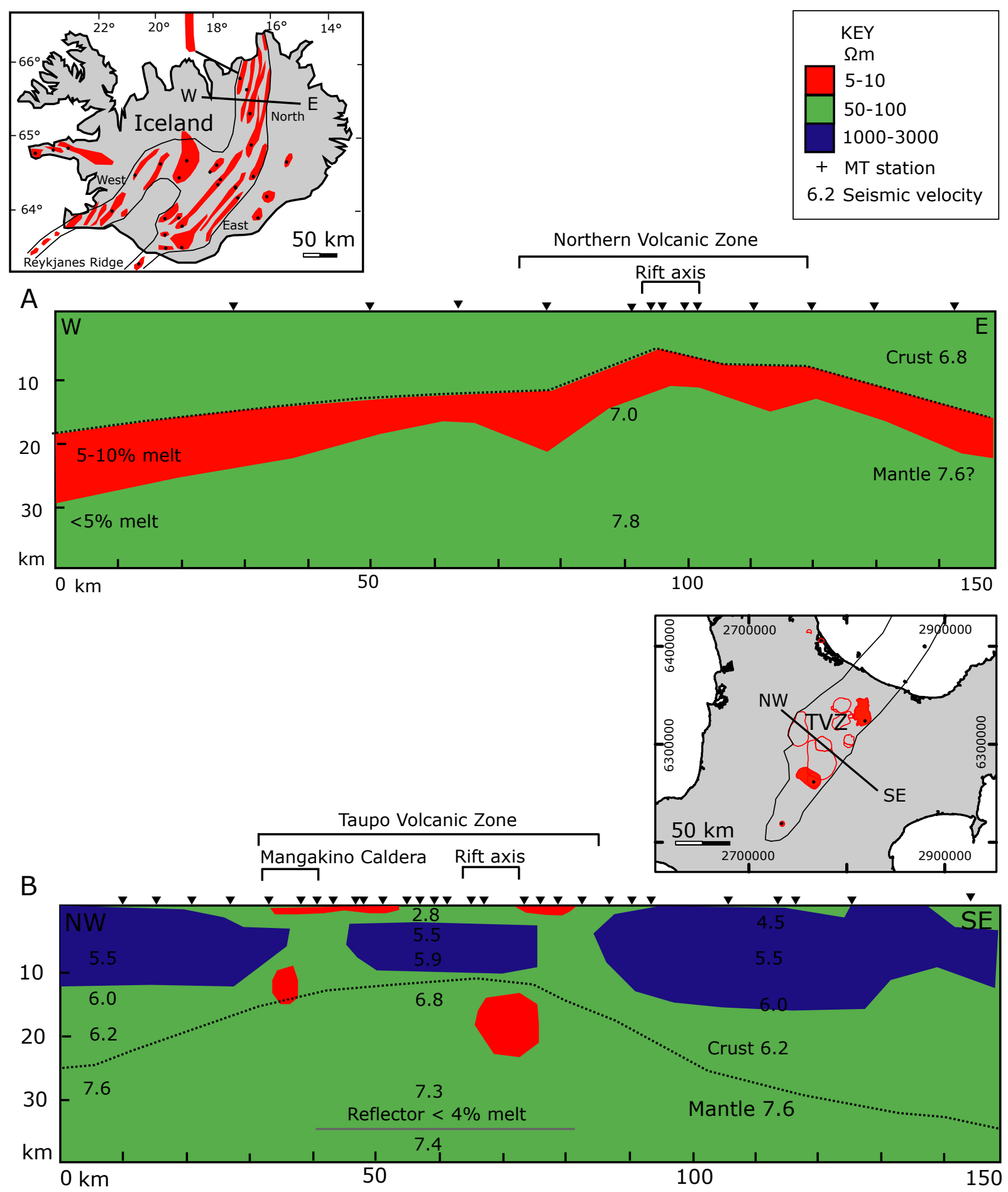

Fig. 4.7. Crustal scale geophysical cross-sections from Iceland and New Zealand. (A) Magnetotelluric (MT) and seismic refraction velocities from the Krafla Rift zone. A 5-10 km thick low resistivity layer interpreted as a zone of $5-10 \%$ partial melt can be traced across the entire rift zone [Bjornsson et al., 2005 and references therein]. Inset: Location of Iceland MT line. (B) Magnetotelluric and seismic refraction velocities from the TVZ and Taupo Rift [Straford \& Stern, 2006; Heise et al., 2007]. High resistivities suggests thinned greywacke crust to $10 \mathrm{~km}$ depth. Isolated conductive positive velocity anomalies underlie the Mangakino Caldera and Taupo Rift axis (only conductors shown here) [Reyners et al., 2006; Heise et al., 2007]. The composition of the lithosphere between $15-30 \mathrm{~km}$ has been interpreted as new igneous crust and anomalous mantle [Stratford \& Stern, 2006] or heavily intruded and underplated crust [Harrison \& White, 2006]. Inset: Location of TVZ Seismic and MT line. 
Immediately below the uppermost layer a conductive (5-10 $\Omega \mathrm{m}$ ) 5-10 km thick layer can be traced continuously for $150 \mathrm{~km}$ perpendicular to the Krafla rift zone (Fig. 4.8). This highly conductive layer has been inferred to comprise 5-10\% partial melt which supplies the magma for the overlying dikes [Bjornsson et al., 2005]. In contrast, the electrical structure of the TVZ differs significantly from the Iceland magnetotelluric profile. The uppermost 3-10 km of the crust comprises non-conductive material ( $>300$ $\Omega \mathrm{m})$ [Heise et al., 2007]. Magnetotelluric data outside the TVZ infer the upper crust is non-conductive (> $500 \Omega \mathrm{m})$ quartzofeldspathic Mesozoic basement, that is also interpreted to underlie the Taupo Rift and the central TVZ [Heise et al., 2007]. The decrease in resistivity at the eastern and western margins of the TVZ may arise due to geothermal activity in these areas [e.g. Bibby et al., 1995]. Below $10 \mathrm{~km}$ depth in the TVZ isolated highly conductive (5-10 $\Omega \mathrm{m}$ ) regions beneath the Whakamaru CalderaTaupo Rift axis (15-25 km depth) and beneath the Mangakino Caldera (10-15 km depth) are observed [Heise et al., 2007]. These conductive anomalies are spatially coincident with regions of anomalously high P-wave velocities (relative to the surrounding material) [Reyners et al., 2006] and could represent isolated mafic crystal-rich mush zones of volcanic systems associated with the caldera complexes [e.g. Annen \& Sparks, 2002; Bachmann et al., 2007].

The spatial coincidence of melt accumulation at depth with the Taupo Rift axis and the limited spatial extent of relatively long-lived caldera complexes and geothermal systems suggest that magma in the crust primarily resides beneath volcanic centres. Outside these volcanic centres the upper $10 \mathrm{~km}$ of crust is dominated by quartzofeldspathic basement and is overlain by low-density conductive volcanic products. Therefore, it is concluded that the Taupo Volcanic Zone has not yet reached the stage of a predominantly magmatically-assisted rift system [e.g. Ebinger \& Casey, 2001]. Within the caldera complexes horizontal extension may be partly accommodated by dike intrusion during magmatic episodes (e.g. OVC), whereas the rift outside these volcanic centres, extension appears to be accommodated predominantly through slip on normal faults.

If dikes are not intruded into the brittle crust between volcanic centres, then another explanation must be found to account for the high heat flow in the TVZ (700 $\mathrm{mW} / \mathrm{m}^{2}$ ) [Stern, 1985; Bibby et al., 1995]. Increased concentrations of fluids from the subduction of thickened oceanic crust and mantle flow northeast along the strike of the subducting Pacific Plate may account for the anomalous concentrations of melt in the mantle beneath, and high surface heat flow in, the TVZ [e.g. Stern, 1985; Reyners et al., 
2006]. Geological and geophysical studies are consistent with mantle-derived basalt being emplaced into the crust at depths $>15$ km [Annen \& Sparks, 2002; Harrison \& White, 2006; Reyners et al., 2006; Stratford \& Stern, 2006; Heise et al; 2007]. Petrological and geochemical studies indicate that mafic cumulates are continuously fluxed into the crust at depths of $20 \pm 5 \mathrm{~km}$ over long periods of time and are consistent with models of continuous melt production in the mantle governed by plate motions [Annen \& Sparks, 2002 and references therein]. These basaltic magmas are inferred to differentiate by crystallization and interact with continental crust (i.e. Mesozoic basement) resulting in contamination and assimilation [e.g. Charlier et al., 2005; Price et al., 2005]. Annen \& Sparks [2002] suggest repetitive intrusion of basaltic sills (at a typical intrusion rate of $5 \mathrm{~mm} / \mathrm{yr}$ ) in deeper parts of the crust over periods of $10^{5}$ to $10^{6}$ years can generate partially melted zones of new crust up to $8 \mathrm{~km}$ thick. This model, together with the high flux of fluids through the TVZ, would be sufficient to generate the cumulative erupted volume, geochemical diversity, crustal properties, and high heat flow observed in the TVZ [Houghton et al., 1995; Charlier et al., 2005; Price et al., 2005; Harrison \& White, 2006; Reyners et al., 2006; Stratford \& Stern, 2006; Heise et al., 2007].

\subsection{Conclusions}

Fault kinematic and GPS data indicate that rift-orthogonal extension dominates across the TVZ. The regional principal horizontal extension direction swings clockwise by $\sim 30^{\circ}$ from south to north along the rift producing an increasing (but small $\leq 20^{\circ}$ ) component of right-lateral slip on faults. The modal principal horizontal extension direction in the region of the OVC trends at $\sim 145^{\circ}$. Active fault traces and gravity indicate that the rift steps to the left by approximately $10 \mathrm{~km}$ across the Okataina Caldera along north-south striking faults, which are inferred to reactivate basement fabric. This hard-linked left-stepping rift geometric model, which includes northeastsouthwest and north-south striking fault sets, differs significantly from the previous right bending models of Acocella et al. [2003] and Spinks et al. [2005].

Fault geometry and PHE data are combined to produce a new model for the relations between faulting and volcanism in the OVC. In this model elevated brittle deformation and dilation at the intersection of the two active fault sets produces zones of crustal weakness which locally promote the rise of magma. This model could apply elsewhere in the TVZ where intersecting faults sets were active during volcanism. Within these volcanic centres dike intrusion may partly accommodate regional 
extension, however, outside these volcanic point sources, extension of the crust appears to be primarily due to normal faulting. 
CHAPTER FIVE

CONCLUSIONS 


\section{Conclusions}

Globally there are many locations where volcanism and faulting co-exist. Close spatial relations between faulting and volcanism invites questions about which of these processes is of greatest importance (i.e. which drives the other). In geological settings where new oceanic crust is forming in association with rifting (e.g. Iceland or Afar) and dike intrusion commonly triggers fault slip in the upper crust [e.g. Rubin \& Pollard, 1988; Rubin, 1992; Ebinger \& Casey, 2001; Gudmundsson, 2002; Wright et al., 2006]. Therefore, in oceanic crust the timing and size of fault slip is controlled by the timing and dimensions of dike intrusion which are, in turn, controlled by relative plate motions. In continental crust the relations between the timing and magnitude of magmatic activity (e.g. dike intrusion) and faulting is less well understood [e.g. Bacon, 1985; Mastin \& Pollard, 1988; Corti et al., 2003; Wallace et al., 2004; Nicol et al, 2006; Villamor \& Berryman, 2006]. This is particularly so in the TVZ where the type of volcanism varies spatially (e.g. rhyolitic lava domes and calderas, andesitic stratovolcanoes) and faults are often poorly resolved by geological or geophysical datasets.

The Okataina Volcanic Centre (OVC), which over the last 22 kyr has been the most active volcanic centre in the TVZ, is intersected by the active Taupo Rift and provides an opportunity to examine the relations between faulting and volcanism. In this thesis the following key questions have been addressed using geological and geophysical data from the OVC; i) Is there evidence for dike intrusion accommodating extension of the crust? ii) Does caldera collapse utilise, and locally increase displacements on existing faults within the OVC? iii) Do faults play a role in localising volcanism? iv) Does the volcanic complex play a role localising faults? v) Do volcanic eruptions trigger fault slip?

The resulting conclusions provide important clues as to what role rift faults play in the formation of volcanism (and vice versa) in the region of study and are summarized by the following points.

1. The Okataina Caldera is elongate in a north-south direction, is confined by, and oblique to, the northeast-southwest trending Taupo Rift (Chapter 2). Active faults of the Taupo Rift pass into the Okataina Caldera complex and partly control its geometry. The northwest and southeast boundaries of the main caldera, which is defined by the gravity anomaly below $-45 \mathrm{mGal}$, dip at $55-75^{\circ}$ and appear to be located along the principal rift 
faults. Segments of the east and west margins of the caldera are near vertical $\left(70-90^{\circ}\right.$ dip) and trend north-south (parallel to the elongation direction of the caldera). These margins are parallel to north-south trending Mesozoic basement fabric and major Tertiary faults at the latitude of the OVC either side of the Central Volcanic Region (Chapter 2). The east and west margins of the caldera are inferred to be faults that formed by the reactivation of a similarly orientated Mesozoic basement fabric (i.e. bedding, terrane boundaries, and/or faults).

2. Gravity models support the caldera collapse location and geometries of the 150 $\mathrm{km}^{3}$ Matahina Ignimbrite (280 ka) and $\sim 100 \mathrm{~km}^{3}$ Rotoiti Pyroclastic (60 ka) eruptions proposed by Nairn [2002] (Chapter 2). Primary caldera collapse events at 280 and $60 \mathrm{ka}$ appear to have utilised pre-existing rift faults and basement fabric, resulting in up to 3 $\mathrm{km}$ of subsidence. This subsidence reaches a maximum at the axis of the rift where the two collapse events overlap in space. The location of calderas appears to influence the density of active faults observed at the ground surface within the rift. Where basement is near to the ground surface (e.g. $<1 \mathrm{~km}$ ) faults accumulate displacement on single large fault slip surfaces while areas with dense arrays of faulting (i.e. average fault trace spacing of $<500 \mathrm{~m}$ ) are often above a deep basement within calderas ( $>2 \mathrm{~km}$ ). Therefore, while the geometries of calderas are controlled by the location and geometry of pre-existing faults, the calderas can, in turn, influence the spatial distribution of nearsurface faulting (Chapter 2).

3. Gravity models of the Okataina Caldera are consistent with the linear volcanic vents zones of the Haroharo and Tarawera post-caldera domes being located vertically above the line of intersection between the caldera floor and the boundary faults along the northwest and southeast margins of the caldera. It is suggested that magma rises up the main rift faults until it strikes the caldera floor; movement of magma along faults in the TVZ has previously been proposed by numerous researchers [e.g. Nairn \& Cole, 1981; Cole, 1990; Wilson et al., 1995; Heiss et al., 2007]. Within the relatively unconsolidated volcanic material that fills the caldera, the buoyancy forces of the rising magma may exceed the tensile strength of the rock, enabling the magma to rise vertically to the surface (Chapters $2 \& 4$ ).

4. Fault displacements over time periods ranging from 60 to 220 ka have been measured in, and adjacent, to the Okataina Volcanic Complex along the Paeroa and 
Whirinaki Fault zones. Displacement rates along these two fault zones, together with historical accounts of the $1886 \mathrm{AD}$ Tarawera eruption, indicate that neither dike intrusion nor caldera collapse have a measurable contribution to faults outside the volcanic complex. Therefore, dike intrusion in $1886 \mathrm{AD}$ did not trigger measurable slip on faults outside the OVC (Chapter 3).

5. In the OVC extension is accommodated by a combination of tectonic faulting, dike intrusion, and gravitational caldera collapse. Within the Whirinaki Fault zone, for example, vertical displacement increases by up to $50 \%$ across the caldera topographic margin towards the inner collapse boundary and is predominantly a result of gravitational collapse during the 60 ka Rotoiti caldera forming eruption (Chapter 3). A model is proposed for the OVC in which regional extension is approximately uniform across the volcanic complex and accommodated by a combination of tectonic faulting and dike intrusion. Assuming that all 11 volcanic eruptions in the OVC since $22 \mathrm{ka}$ produced a new dike of $5 \mathrm{~m}$ width (i.e. the maximum width for the 1886 AD Tarawera eruption dike close to the surface), dike intrusion accommodates less than half of the $\sim 10 \mathrm{~mm} / \mathrm{yr}$ extension [Villamor \& Berryman, 2001; Wallace et al., 2004] in the upper crust across the OVC. Gravitational caldera collapse is superimposed on, but does not contribute to, regional extension (Chapter 3).

6. Active fault traces and gravity modelling indicate that the rift steps to the left by approximately $10 \mathrm{~km}$ across the Okataina Caldera and is hard-linked via north-south striking faults. The left-stepping, hard-linked geometry differs significantly from the previous right bending models of Acocella et al. [2003] and Spinks et al. [2005] which are not supported by the available data (Chapter 4).

7. Fault kinematic and GPS data indicate that rift-orthogonal extension dominates across the Taupo Rift. The principal horizontal extension direction swings clockwise by $30^{\circ}$ from south to north along the rift producing an increasing (but always small, $\leq 20^{\circ}$ ) component of right-lateral slip on faults (Chapter 4). The modal principal horizontal extension direction in the region of the OVC trends at $\sim 145^{\circ}$, approximately normal to northeast striking rift faults and oblique to north-south faults. Thus, northeast striking faults are dip slip, while north-south faults may carry equal components of right-lateral and normal slip (Chapter 4). 
8. A new model for the relations between faulting and volcanism is developed for the OVC using fault geometry and principal horizontal extension data. Volcanic vent alignments parallel to rift faults and caldera elongation along both northeast-southwest and north-south trends suggest that the fault sets are pervasive in the OVC. Zones of crustal weakness, brittle deformation, and dilation at the intersection of northeastsouthwest dip slip and north-south oblique slip active fault sets are inferred to locally promote the ascent of magma (Chapter 4). Intersection of these fault sets may influence the location and alignment of volcanism throughout the TVZ (Chapter 4).

9. Normal faulting in the Taupo Rift outside of active TVZ volcanic centres (e.g. Taupo and Okataina) is primarily driven by tectonic processes (e.g. far-field plate motions) and is not attributed to dike intrusion. Fault displacement analysis, the fault controlled geometry of the Okataina (and other TVZ calderas), the limited spatial distribution of volcanism and high geothermal heat flow along the rift, together with a $70 \mathrm{~km}$ deep magnetotelluric profile suggest that the Taupo Rift has not yet reached the stage of magma-assisted extension and is primarily a young tectonic rift in an arc environment. 


\section{REFERENCES}

Acocella, V.; Korme, T.; Salvini, F.; Funiciello, R. (2002) Elliptic calderas in the Ethiopian Rift: control of pre-existing structures. Journal of Volcanology and Geothermal Research 119: 189-203

Acocella, V.; Spinks, K.; Cole, J.; Nicol, A. (2003) Oblique back arc rifting of Taupo Volcanic Zone, New Zealand. Tectonics 22 (4): 1045

Anderson, H.; Webb, T. (1989) The rupture process of the 1987 Edgecumbe earthquake, New Zealand. New Zealand Journal of Geology \& Geophysics 32: 43-52

Annen, C.; Sparks, R. S. J. (2002) Effects of repetitive emplacement of basltic intrusions on the thermal evolution and melt generation in the crust. Earth \& Planetary Science Letters 203: 937-955

Arnold, R.; Townend, J. (2007) A Bayesian approach to estimating tectonic stress from seismological data. Geophysics Journal International 170 (3): 1336-1356, doi: 10.1111/j.1365-246X.2007.03485.x

Bachmann, O.; Miller, C. F.; de Silva, S. L. (2007) The volcanic-plutonic connection as a stage for understanding crustal magmatism. Journal of Volcanology and Geothermal Research 167: 1-23, doi: 10.1016/j.jolgeores.2007.08.002

Bacon, C. R. (1985) Implications of silicic vent patterns for the presence of large crustal magma chambers. Journal of Geophysical Research 90 (B13): 11243-11252

Ballance, P. F. (1976) Evolution of the upper Cenozoic magmatic arc and plate boundary in northern New Zealand. Earth \& Planetary Science Letters 28: 356370

Bannister, S.; Bryan, C.J.; Bibby, H.M. (2004) Shear wave velocity variation across the Taupo Volcanic Zone, New Zealand, from receiver function inversion. Geophysics Journal International 159: 291-310 doi: 10.1111/j.1365-246X.2004.02384.X

Beanland, S.; Berryman, K. R.; Blick, G. H. (1989) Geological investigations of the 1987 Edgecumbe earthquake, New Zealand. New Zealand Journal of Geology \& Geophysics 32: 73-91

Beavan, J.; Haines, J. (2001) Contemporary horizontal velocity and strain rate fields of the Pacific-Australian plate boundary zone through New Zealand. Journal of Geophysical Research 106 (B1): 741-770

Beavan, J.; Tregoning, P.; Bevis, B.; Kato, T.; Meertens, C. (2002) The motion and rigidity of the Pacific Plate and implications for plate boundary deformation. Journal Geophysical Research 107 (B10): 2261 doi: 10.1029/2001B000282

Beavan, J.; Ellis, S.; Wallace, L.; Denys, P. (2007) Kinematic constraints from GPS on oblique convergence of the Pacific and Australian Plates, Central South Island, New Zealand in A Continental Plate Boundary: Tectonics at South Island, New 
Zealand (eds) D. Okaya, T. Stern, F. Davey. Geophysical Monograph 175. American Geophysical Union, Washington, DC. pgs 75-95

Berryman, K.; Villamor, P.; Nairn, I.; Van Dissen, R.; Begg, J.; Lee, J. (in review) Late Quaternary surface rupture history of the Paeroa Fault, Taupo Rift, New Zealand.

Bibby, H. M.; Caldwell, T. G.; Davey, F. J.; Webb, T. H. (1995) Geophysical evidence on the structure of the Taupo Volcanic Zone and its hydrothermal circulation. Journal of Volcanology and Geothermal Research 68: 29-58

Björnsson, A.; Eysteinsson, H.; Beblo, M. (2005) Crustal formation and magma genesis beneath Iceland: Magnetotelluric constrains, in G. R. Foulger, J. H. Natland, D. C. Presnall, D. L. Anderson (eds); Plate, plumes, and paradigms: Geological Society of America Special Paper 338: 665-686, doi: 10.1130/2005.2388(38)

Bosworth, W. (1985) Geometry of propagating continental rifts. Nature 316: 625-627

Bosworth, W.; Burke, K.; Strecker, M. (2003) Effects of stress fields on magma chamber stability and the formation of collapse calderas. Tectonics 22 (4): 1042

Briggs, R.M.; Houghton, B.F.; McWilliams, M.; Wilson, C.J.N. (2005) 40Ar/39Ar ages of silicic volcanic rocks in the Tauranga-Kaimai area, New Zealand: dating the transition between volcanism in the Coromandel Arc and the Taupo Volcanic Zone. New Zealand Journal of Geology \& Geophysics 48: 459-469

Bryan, C. J.; Sherburn, S.; Bibby, H. M.; Bannister, S. C.; Hurst, A. W. (1999) Shallow seismicity of the central Taupo Volcanic Zone, New Zealand: its distribution and nature. New Zealand Journal of Geology and Geophysics 42: 533-542

Campbell, M. E.; Rowland, J. V.; Wright, I. C.; Smith, I. E. M. (2007) Oblique rifting along the central and southern Kermadec Arc front $\left(30^{\circ}-36^{\circ} \mathrm{S}\right)$, SW Pacific. Geochemistry Geophysics Geosystems 8 (1): doi: 10.1029/2006GC001504

Canon-Tapia, E.; Walker, G. P. L. (2004) Global aspects of volcanism: the perspectives of "plate tectonics" and "volcanic systems". Earth Science Reviews 66: 163-182, doi: 10.1016/j.earscirev.2003.11.001

Carle, S. F.; Goldstein, N. E. (1987) A three-dimensional gravity model of the geologic structure of Long Valley Caldera. Lawerence Berkeley Laboratory Earth Science division Annual Report: 99-103

Carter, L.; Shane, P.; Alloway., B.; Hall, I. R.; Harris, S. E.; Westgate, J. A. (2003) Demise of one volcanic zone and birth of another-A 12 m.y. marine record of major rhyolitic eruptions from New Zealand. Geology 31 (6): 493-496

Charlier, B. L. A.; Wilson, C. J. N.; Lowenstern, J. B.; Blake, S.; Van Calsteren, P. W.; Davidson, J. P. (2005) Magma generation at a large, hyperactive silicic volcano (Taupo, New Zealand) revealed by U-Th and U-Pb systematics in zircons. Journal of Petrology 46: 3-32, doi:10.1093/petrology/egh060

Cole (1970) Structure and eruptive history of the Tarawera Volcanic Complex. New Zealand Journal of Geology \& Geophysics 13: 879-902 
Cole, J. W. (1990) Structural control and origin of volcanism in the Taupo Volcanic Zone, New Zealand. Bulletin of Volcanology 52: 445-459

Cole, J. W.; Gamble, J. A.; Burt, R. M.; Carroll, L. D.; Shelly, D. (2001) Mixing and mingling in the evolution of andesite-dacite magmas; evidence from co-magmatic plutonic enclaves, Taupo Volcanic Zone, New Zealand. Lithos 59: 25-46

Cole, J. W.; Milner, D. M.; Spinks, K. D. (2005) Calderas and caldera structures: a review. Earth-Science Reviews 69: 1-26

Cordell, L. (1973) Gravity analysis using an expontential density-depth function - San Jacinto Graben, California. Geophysics 38 (4): 684-690

Corti, G.; Bonini, M.; Conticelli, S.; Innocenti, F.; Manetti, P.; Sokoutis, D. (2003) Analogue modelling of continental extension: a review on the relations between the patterns of deformation and the presence of magma. Earth-Science Reviews 63: 169-247

Darby, D. J.; Hodgkinson, K. M.; Blick, G. H. (2000) Geodetic measurement of deformation in the Taupo Volcanic Zone, New Zealand: the north Taupo network revisited. New Zealand Journal of Geology \& Geophysics 43: 157-170

Davey, F.J.; Henrys, S.A.; Lodolo, E. (1995) Asymmetric rifting in a continental backarc environment, North Island, New Zealand. Journal of Volcanology and Geothermal Research 68: 209-238

Davy, B.; Bibby, H. (2005) Seismic reflection imaging of the Haroharo Caldera boundary beneath Lake Tarawera, Okataina Volcanic Centre, New Zealand. New Zealand Journal of Geology \& Geophysics 48: 153-166

Davy, B. W.; Caldwell, T. G. (1998) Gravity, magnetic and seismic surveys of the caldera complex Lake Taupo, North Island, New Zealand. Journal of Volcanology and Geothermal Research 81: 69-89

Ebinger, C. J.; Casey, M. (2001) Continental breakup in magmatic provinces: An Ethiopian example. Geology 29 (6): 527-530

Edbrooke, S. W. (compiler) (2001) Geology of the Auckland area. Institute of Geological \& Nuclear Sciences 1:250 000 geological map 3. Lower Hutt, New Zealand. GNS Science

Edbrooke,. S. W. (compiler) (2005) Geology of the Waikato area. Institute of Geological \& Nuclear Sciences 1:250 000 geological map 4. Lower Hutt, New Zealand. GNS Science

Ferguson, J. F.; Cogbill, A. H.; Warren, R. G. (1994) A Geophysical-geological transect of the Silent Canyon caldera complex, Pahute Mesa, Nevada. Journal of Geophysical Research 99 (B3): 4323-4339

Freeman, T. (1996) What is imaging radar? http://airsar.jpl.nasa.gov/documents/genairsar/radar.html 
Forslund, T. Gudmundsson, A. (1992) Structure of Tertiary and Plaistocene normal faults in Iceland. Tectonics 11 (1): 57-68

GEONET New Zealand Earthquake Catalogue http://magma.geonet.org.nz/resources/quakesearch

GNS Science New Zealand Active Faults Database http://www.gns.cri.nz/af/

GNS Science New Zealand Land Gravity Database http://www.gns.cri.nz/website/gravity/

GNS Science PETLAB New Zealand Rock Catalogue and Geoanalytical Database http://pet.gns.cri.nz

Grindley, G. W. (1960) Sheet 8 - Taupo. Geological map of New Zealand, 1:250 000. Wellington, New Zealand. Department of Scientific and Industrial Research

Gudmundsson, A. (1998) Magma chambers modelled as cavities explain the formation of rift zone central volcanoes and their eruption statistics. Journal of Geophysical Research 103 (B4): 7401-7412

Gudmundsson, A. (2000) Dynamics of Volcanic Systems in Iceland: Example of tectonism and volcanism at juxtaposed hot spot and mid-ocean ridge systems. Annual Reviews of Earth and Planetary Sciences 28: 107-140

Gudmundsson, A. (2002) Emplacement and arrest of sheets and dykes in central volcanoes. Journal of Volcanology and Geothermal Research 116: 279-298

Harrison, A. J.; White, R. S. (2006) Lithospheric structure of an active backarc basin: the Taupo Volcanic Zone, New Zealand. Geophysics Journal International 167: 698-990, doi: 10.1111/j.1365-246X.2006.03166.x

Hayes, G.; Reyners, M.; Stuart, G. (2004) The Waiouru, New Zealand, earthquake swarm: Persistent mid crustal activity near an active volcano. Geophysical Research Letters 31: L19613, doi:10.1029/2004GL020709

Hayward, B. W.; Black, P. M.; Smith, I. E. M.; Balance, P. F.; Itaya, T.; Doi, M.; Takagi, M.; Bergman, S.; Adams, C. J.; Herzer, R. H.; Robertson, D. J. (2001) KAr ages of early Miocene arc-type volcanoes in northern New Zealand. New Zealand Journal of Geology \& Geophysics 44: 285-311

Hayward, N. J.; Ebinger, C. J. (1996) Variations in the along-axis segmentation of the Afar Rift system. Tectonics 15 (2): 244-257

Healy, J.; Schofield, J. C.; Thompson, B. N. (1964) Sheet 5 Rotorua 1:250 000 Geological Map of New Zealand. Department of Scientific and Industrial Research, Wellington, New Zealand

Heise, W.; Bibby, H. M.; Caldwell, T. G.; Bannister, S. C.; Ogawa, Y.; Takakura, S; Uchida, T. (2007) Melt distribution beneath a young continental rift: The Taupo 
Volcanic Zone, New Zealand. Geophysical Research Letters 34: L14313, doi: 10.1029/2007GL029629

Heiss, J.; Cole, J. W.; Spinks, K. D. (2007) Influence of the crust and crustal structure on the location and composition of high-alumina basalts of the Taupo Volcanic Zone, New Zealand. New Zealand Journal of Geology \& Geophysics 50: 327-342

Houghton, B. F.; Wilson, C. J. N.; McWilliams, M. O.; Lanphere, M. A.; Weaver, S. D.; Briggs, R. M.; Pringle, M. S. (1995) Chronology and dynamics of a silicic magmatic system: Central Taupo Volcanic Zone, New Zealand. Geology 23 (1): $13-16$

Hughes, C. J.; Rowland, J. R.; Wilson, C. J. N.; Manville, V.; Leonard, G. S. (2004) Structural evolution of the north rim of Taupo Volcano. Geo ${ }^{3}$ Taupo 2004 Programme \& Abstracts. Geological Society of New Zealand Miscellaneous Publication 117A.: 49-50

Hurst, A. W.; Bibby, H. M.; Robinson, R. R. (2002) Earthquake focal mechanisms in the central Taupo Volcanic Zone and their relation to faulting and deformation. New Zealand Journal of Geology and Geophysics 45: 527-536

Hurst, A. W.; Bannister, S.; Robinson, R.; Scott, B. (2008) Characteristics of three recent earthquake sequences in the Taupo Volcanic Zone, New Zealand. Tectonophysics: in press, doi: 10.1016/j.tecto.2008.01.017

King, P. R.; Thrasher, G. P. (1996) Cretaceous-Cenozoic geology and petroleum systems of the Taranaki Basin. Institute of Geological \& Nuclear Sciences monograph 13. Institute of Geological \& Nuclear Sciences Limited, Lower Hutt, New Zealand.

Kearey, P.; Brooks, M.; Hill, I. (2002) An Introduction to Geophysical Exploration. Blackwell Science, Oxford, pg 125

Kendall, J. M.; Stuart, G. W.; Ebinger, C. J.; Bastow, I. D.; Keir, D. (2005) Magmaassisted rifting in Ethiopia. Nature 433: 146-148

Keranen, K.; Klemperer, S. L. (2008) Discontinuous and diachronous evolution of the Main Ethiopian Rift: Implications for development of continental rifts. Earth \& Planetary Science Letters 265: 96-111

Kim, Y.; Sanderson, D. J. (2005) The relationship between displacement and length of faults: a review. Earth-Science Reviews 68: 317-334

Kim, Y.; Andrews, J. R.; Sanderson, D. J. (2000) Damage zones around strike-slip fault systems and slip-slip evolution, Crackington Haven, southwest England.

Geosciences Journal 4 (2): 5-72

King, P.R. (2000) Tectonic reconstructions of New Zealand: 40 Ma to the Present. New Zealand Journal of Geology and Geophysics 43: 611-638 
Korme, T.; Chorowicz, J.; Collet, B.; Bonavia, F.F. (1997) Volcanic vents rooted on extension fractures and their geodynamic implications in the Ethiopian Rift. Journal of Volcanology and Geothermal Research 79: 205-222

Korme, T.; Acocella, V.; Abebe, B. (2004) The role of pre-existing structures in the origin, propagation and architecture of faults in the Main Ethiopian Rift. Gondwana Research 7 (2): 467-479

Lamarche, G.; Barnes, P. M.; Bull, J. M. (2006) Faulting and Extension Rate over the last 20,000 Years in the Offshore Whakatane Graben, New Zealand Continental Shelf. Tectonics 25: TC4005, doi: 10.1029/2005TC001886

Leonard, G; Begg, J, G. (compliers) (In preparation). Geology of the Rotorua area. Institute of Geological \& Nuclear Sciences 1:250 000 geological map 5. Lower Hutt, New Zealand. GNS Science

Leonard, G.S.; Cole, J.W.; Nairn, I.A.; Self, S. (2002) Basalt triggering of the c. AD 1305 Kaharoa rhyolite eruption, Tarawera Volcanic Complex, New Zealand. Journal of Volcanology and Geothermal Research 115: 461-486

Lipman, P. W. (1997) Subsidence of ash-flow calderas: relation to caldera size and magma-chamber geometry. Bulletin of Volcanology 59: 198-218

Lund, B.; Townend, J. (2007) Calculating horizontal stress orientations with full or partial knowledge of the tectonic stress tensor. Geophysics Journal International 170 (3): 1328-1335, doi: 10.1111/j.1365-246X.2007.03468.x

Madsen, S.N.; Martin, J.M.; Zebker, H.A. (1995) Analysis and Evaluation of the NASA/JPL TOPSAR Across-Track Interferometric SAR System. IEEE Transactions on Geoscience and Remote Sensing 33 (2): 383-391

Maerten, L.; Willemse, E. J. M.; Pollard, D. D.; Rawnsley, K. (1999) Slip distributions on intersecting normal faults. Journal of Structural Geology 21: 259-271

Marrett, R.; Allmendinger, R. W. (1990) Kinematic analysis of fault-slip data. Journal of Structural Geology 12: 973-986

Mastin, L. G.; Pollard, D. D. (1988) Surface deformation and shallow dike intrusion processes at Inyo Craters, Long Valley, California (1988) Journal of Geophysical Research 93 (B11): 13221-13235

Milner, D.M., Cole, J.W., Wood, C.P., 2002. Asymmetric, multiple-block collapse at Rotorua Caldera, Taupo Volcanic Zone, New Zealand. Bulletin of Volcanology 64, 134-149 doi 10.1007/s00445-001-0191-0

Modriniak, N.; Studt, F.E. (1959) Geological structure and volcanism of the TaupoTarawera District. New Zealand Journal of Geology and Geophysics 2: 654-684

Moore, I.; Kokelaar, P. (1998) Tectonically controlled piecemeal caldera collapse: A case study of Glencoe volcano, Scotland. GSA Bulletin 110 (11): 1448-1466 
Morley, C. K. (1999) Influence of pre-existing fabrics on rift structure. In C. K. Morley ed., Geoscience of Rift Systems - Evolution of East Africa: AAPG Studies in Geology 44: 151-160

Mortimer, N. (2004) New Zealand's Geological Foundations. Gondwana Research 7 (1): 261-272

Mortimer, N. (2006) Crustal structure of the central North Island basement: A petrotectonic perspective. Geological Society of New Zealand Miscellaneous Publication 122 A: 53

Mortimer, N.; Herzer, R. H.; Gans, P. B.; Laporte-Magoni, C.; Calvert, A. T.; Bosch, D. (2007) Oligocene-Miocene tectonic evolution of the South Fiji Basin and Northland Plateau, SW Pacific Ocean: Evidence from petrology and dating of dredged rocks. Marine Geology 237: 1-24, doi: 10.1016/j.margeo.2006.10.033

Mouslopoulou, V.; Nicol, A.; Little, T.A.; Walsh, J.J. (2007) Displacement transfer between intersecting regional strike-slip and extensional fault systems. Journal of Structural Geology 29 (1): 100-116

Mouslopoulou, V.; Nicol, A.; Walsh, J.J.; Beetham, D.; Stagpoole, V. (2008) Quaternary temporal stability of a regional strike-slip and rift fault intersection. Journal of Structural Geology 30 (4): 451-463

Mumme, T. C.; Lamb, S. H; Walcott, R. I. (1989) The Raukumara paleomagnetic domain: constraints on the tectonic rotation of the east coast, North Island, New Zealand. New Zealand Journal of Geology \& Geophysics 32: 317-326

Nairn, I. A. (1989) VC16AC: 55 Mount Tarawera. Geological map of New Zealand 1:50 000. Map (1 sheet) and notes. Wellington, New Zealand, Department of Scientific and Industrial Research.

Nairn, I. A. (2002) Geology of the Okataina Volcanic Centre, scale 1:50 000. Institute of Geological \& Nuclear Sciences geological map 25. 1 sheet +156 p. Lower Hutt, New Zealand: Institute of Geological \& Nuclear Sciences Limited.

Nairn, I.A.; Beanland, S. (1989) Geological setting of the 1987 Edgecumbe earthquake, New Zealand. New Zealand Journal of Geology and Geophysics 32: 1-13

Nairn, I. A.; Cole, J. W. (1981) Basalt dikes in the 1886 Tarawera Rift. New Zealand Journal of Geology \& Geophysics 24: 585-592

Nairn, I. A.; Shane, P. R.; Cole, J. W.; Leonard, G. J.; Self, S.; Pearson, N. (2004) Rhyolite magma processes of the $\sim \mathrm{AD} 1315$ Kaharoa eruption episode, Tarawera volcano, New Zealand. Journal of Volcanology and Geothermal Research 131: 265-294, doi: 10.1016/S0377-0273(03)00381-0

Nairn, I. A.; Hedenquist, J. W.; Villamor, P.; Berryman, K. R.; Shane, P. A. (2005) The 1315 Tarawera and Waiotapu eruptions, New Zealand: contemporaneous rhyolite and hydrothermal eruptions driven by an arrested basaltic dike system? Bulletin of Volcanology 67: 186-193, doi 10.1007/s00445-004-0373-7 
Nicol, A.; Wallace, L. M. (2007) Temporal stability of deformation rates: Comparison of geological and geodetic observations, Hikurangi subduction margin, New Zealand. Earth \& Planetary Science Letters 258: 397-413 doi:10.1016/j.epsl.2007.03.039

Nicol, A; Walsh, J.; Berryman, K.; Nodder, S. (2005) Growth of a normal fault by the accumulation of slip over millions of years. Journal of Structural Geology 27: 327-342

Nicol, A.; Walsh, J.; Berryman, K.; Villamor, P. (2006) Interdependence of fault displacement rates and paleoearthquakes in an active rift. Geology 34 (10): 865868 doi: 10.1130/G22335.1

Nicol, A.; Mazengarb, C.; Chanier, F.; Rait, G.; Uruski, C.; Wallace, L. (2007) Tectonic evolution of the active Hikurangi subduction margin, New Zealand, since the Oligocene. Tectonics 26: TC4002, doi:10.1029/2006TC002090

Parsons, T.; Thompson, G. A. (1993) Does magmatism influence low-angle normal faulting? Geology 21: 247-250

Prejean, S.; Ellsworth, W.; Zoback, M.; Waldhauser, F. (2002) Fault structure and kinematics of the Long Valley Calder region, California, revealed by highaccuracy earthquake hypocenters and focal mechanism stress inversion. Journal of Geophysical Research 107 (B12): 2355 doi: 10.1029/2001JB001168

Price, R. C.; Gamble, J. A.; Smith, I. E. M.; Stewart, R. B.; Eggins, S.; Wright, I. C. (2005) An integrated model for the temporal evolution of andesites and rhyolites and crustal development in New Zealand's North Island. Journal of Volcanology and Geothermal Research 140: 1-24 doi: 10.1016/j.jvolgeores.2004.07.013

Reilly, W. I. (1972) New Zealand Gravity Map Series. New Zealand Journal of Geology \& Geophysics 15 (1): 3-15

Reyners, M.; Eberhart-Phillips, D.; Stuart, G.; Nishimura, Y. (2006) Imaging subduction from the trench to $300 \mathrm{~km}$ depth beneath the central North Island, New Zealand with Vp and Vp/Vs. Geophysics Journal International 165: 565-583 doi: 10.1111/j.1365-246X.2006.02897.x

Richardson, W. P. (1989) The Matata earthquake of 1977 May 31: a recent event near Edgecumbe, Bay of Plenty, New Zealand. New Zealand Journal of Geology \& Geophysics 32: 17-30

Ring, U. (1994) The influence of pre-existing structure on the evolution of the Cenozoic Malawi rift (East African rift system). Tectonics 13 (2): 313-326

Robinson, R. (1989) Aftershocks of the 1987 Edgecumbe earthquake, New Zealand: seismological and structural studies using portable seismographs in the epicentral region. New Zealand Journal of Geology \& Geophysics 32: 61-72

Robinson, R.; McGinty, P. (2000) The enigma of the Arthur's Pass, New Zealand, earthquake 2. The aftershock distribution and its relation to regional and induced stress fields. Journal of Geophysical Research 103: 16139-16150 
Robinson, R.; Smith, E. G. C.; Latter, J. H. (1981) Seismic studies of the crust under the hydrothermal areas of the Taupo Volcanic Zone, New Zealand. Journal of Volcanology of Geothermal Research 9: 253-267

Rogan, A. M. (1980) Geophysical Studies of the Okataina Volcanic Centre. Unpublished $\mathrm{PhD}$ thesis, University of Auckland

Rogan, A. M. (1982) A geophysical study of the Taupo Volcanic Zone, New Zealand. Journal of Geophysical Research 87 (B5): 4073-4088

Rogan, M.; Hochstein, M. P. (1984) Magnetic survey of the 1886 Tarawera rift. New Zealand Journal of Geology and Geophysics 27 (3): 237-245

Rowland, J. V.; Sibson, R. H. (2001) Extensional fault kinematics within the Taupo Volcanic Zone, New Zealand: soft-linked segmentation of a continental rift system. New Zealand Journal of Geology and Geophysics 44: 271-283

Rowland, J.; Wilson, C.; Gravley, D. (2007) Along-axis variations in the rifting process, Taupo Volcanic Zone. In: Joint Geological Society of New Zealand \& New Zealand Geophysical Society Conference Tauranga 2007 Programme \& Abstracts. Geological Society of New Zealand Miscellaneous Publication 123A: 146

Rubin, A. M. (1992) Dike-induced faulting and graben subsidence in volcanic rift zones. Journal of Geophysical Research 97 (B2): 1839-1858

Rubin, A. M.; Pollard, D. D. (1988) Dike-induced faulting in rift zones of Iceland and Afar. Geology 16: 413-417

Ruppel, C. (1995) Extensional processes in continental lithosphere. Journal of Geophysical Research 100 (B12): 24187-24215

Sanderson, D. J.; Zhang, X. (1999) Critical stress localisation of flow associated with deformation of well-fractures rock masses, with implications for mineral deposits. In: McCaffrey, K. J. W.; Lonergan, L.; Wilkinson, J. J. (eds) Fractures, Fluid Flow and Mineralization. Geological Society, London, Special Publications 155: 69-81

Shane, P.; Nairn, I.A.; Smith, V.C. (2005) Magma mingling in the 50 ka Rotiti eruption from Okataina Volcanic Centre: implications for geochemical diversity and chronology of large volume rhyolites. Journal of Volcanology and Geothermal Research 139: 295-313

Sherburn, S.; Bannister, S.; Bibby, H. (2003) Seismic velocity structure of the central Taupo Volcanic Zone, New Zealand, from local earthquake tomography. Journal of Volcanology and Geothermal Research 122: 69-88

Smith, N., Cassidy, J., Locke, C.A., Mauk, J.L., Christie, A.B., 2006. The role of regional-scale faults in controlling a trapdoor caldera, Coromandel Peninsula, New Zealand. Journal of Volcanology and Geothermal Research 149, 312-328 doi: 10.1016/j.jvolgeores.2005.09.005 
Smith, S. P. (1886) The eruption of Tarawera: A report to the Surveyor-General. Government Printer, Wellington: 65-68

Smith, V. C.; Shane, P.; Nairn, I. A. (2004) Reactivation of a rhyolitic magma body by new rhyolitic intrusion before the 15.8 ka Rotorua eruptive episode: implications for magma storage in the Okataina Volcanic Centre, New Zealand. Journal of the Geological Society, London 161: 757-772

Spinks, K.; Urzua, L.; Cumming, B; Bowyer, D. (2005) The geology and geothermal exploration of Mangakino. New Zealand Geothermal Workshop, Rotorua.

Spinks, K. D.; Acocella, V.; Cole, J. W.; Bassett, K. N. (2005) Structural control of volcanism and caldera development in the transtensional Taupo Volcanic Zone, New Zealand. Journal of Volcanology and Geothermal Research 144: 7-22

Stagpoole, V. M. (1994) Interpretation of Refraction Seismic and Gravity data across the Eastern Margin of the Taupo Volcanic Zone, New Zealand. Geothermics 23 (5/6): 501-510

Stagpoole, V.; Bibby, H. M. (1999) Residual gravity anomaly map of the Taupo Volcanic Zone, New Zealand, 1:250 000. Institute of Geological \& Nuclear Sciences Geophysical Map 13. Institute of Geological \& Nuclear Sciences Ltd, Lower Hutt, New Zealand.

Stern, T. A. (1979) Regional and residual gravity fields, central North Island, New Zealand. New Zealand Journal of Geology \& Geophysics 22 (4): 479-485

Stern, T. A. (1982) Seismic and gravity investigations of the Central Volcanic Region, North Island, New Zealand. Unpubl. Ph.D. Thesis. Victoria University of Wellington, Wellington.

Stern, T. A. (1985) A back-ac basin formed within continental lithosphere: the Central Volcanic Region of New Zealand. Tectonophysics 112: 385-409

Stern, T. A. (1986) Geophysical studies of the upper crust within the central volcanic region, New Zealand. In: I. E. M. Smith (ed) Cenozoic Volcanism. Royal Society of New Zealand Bulletin 23: 92-111

Stern, T. A. (1987) Asymmetric back-arc spreading, heat flux and structure associated with the Central Volcanic Region of New Zealand. Earth and Planetary Science Letters 85: 265-276

Stratford, W. R.; Stern, T. A. (2006) Crust and upper mantle structure of a continental backarc: central North Island, New Zealand. Geophysics Journal International 166: 469-484 doi: 10.1111/j.1365-246X.2006.02967.x

Stratford, W. R.; Stern, T. A. (2008) Geophysical imaging of buried volcanic structures within a continental bac-arc basin: The Central Volcanic Region, North Island, New Zealand. Journal of Volcanology and Geothermal Research: doi: 10.1016/j.jvolgeores.2008.02.011 
Tommasi, A; Vauchez, A. (2001) Continental rifting parallel to ancient collisional belts: an effect of the mechanical anisotropy of the lithospheric mantle. Earth \& Planetary Science Letters 185: 199-210

Villamor, P.; Berryman, K. (2001) A late Quaternary extension rate in the Taupo Volcanic Zone, New Zealand, derived from fault slip data. New Zealand Journal of Geology and Geophysics 44: 243-269

Villamor, P.; Berryman, K.R. (2006) Evolution of the southern termination of the Taupo Rift, New Zealand. New Zealand Journal of Geology and Geophysics 49: 23-37

Walcott, R. I. (1987) Geodetic strain and the deformation history of the North Island of New Zealand during the late Cainozoic. Philosophical Transactions of the Royal Society of London 321: 163-181

Wallace, L. M.; Beavan, J.; McCaffrey, R.; Darby, D. (2004) Subduction zone coupling and tectonic block rotations in the North Island, New Zealand. Journal of Geophysical Research 109: B12406

Walsh, J. J.; Watterson, J. (1992) Populations of faults and fault displacements and their effects on estimates of fault-related regional extension. Journal of Structural Geology 14: 701-712

Walsh, J. J.; Nicol, A.; Childs, C. (2002) An alternative model for the growth of faults. Journal of Structural Geology 24: 1669-1675

Watterson, J.; Nicol, A.; Walsh, J. J. (1998) Strains at the intersection of synchronous conjugate normal faults. Journal of Structural Geology 20 (4): 363-370

Webb, T. A.; Anderson, H. (1998) Focal mechanism of large earthquakes in the North Island of New Zealand: slip partitioning at an oblique active margin. Geophysical Journal International 134: 40-86

Wilson, C.J.N.; Rogan, A.M.; Smith, I.E.M.; Northey, D.J.; Nairn, I.A.; Houghton, B.F. (1984) Caldera Volcanoes of the Taupo Volcanic Zone, New Zealand. Journal of Geophysical Research 89 (B10): 8463-8484

Wilson, C. J. N.; Houghton, B. F.; McWilliams, M. O.; Lanphere, M. A.; Weaver, S. D; Briggs, R. M. (1995) Volcanic and structural evolution of Taupo Volcanic Zone, New Zealand: a review. Journal of Volcanology and Geothermal Research 68: 128

Wood, C. P. (1995) Calderas and geothermal systems in the Taupo Volcanic Zone, New Zealand. Proceedings of the World Geothermal Congress '95, Florence, Italy: 1331-1336

Wood, C. P. (2001) Basement structure, lithology and permeability at Kawerau and Ohaaki geothermal fields, New Zealand. Geothermics 30: 461-481

Woodward, D. J. (1988) Seismic Reflection Survey on the Rangitaiki Plains, Eastern Bay of Plenty, New Zealand. Geophysics Division: Department of Scientific and Industrial Research Report 218 
Woodward, D. J. (1989) Geological structure of the Rangitaiki Plains near Edgecumbe, New Zealand, from seismic data. New Zealand Journal of Geology \& Geophysics 32: $15-16$

Wright, I. C. (1992) Shallow structure and active tectonism of an offshore continental back-arc spreading system: the Taupo Volcanic Zone, New Zealand. Marine Geology 103: 287-309

Wright, T. J.; Ebinger, C.; Biggs, J.; Ayele, A; Yirgu, G.; Keir, D.; Stork, A. (2006) Magma-maintained rift segmentation at continental rupture in the 2005 Afar dyking episode. Nature 442: 291-294 doi:10.1038/nature04978

Wright, I. C.; Worthington, T. J.; Gamble, J. A. (2006) New multibeam mapping and geochemistry of the $30^{\circ}-35^{\circ} \mathrm{S}$ sector, and overview, of southern Kermadec arc volcanism. Journal of Volcanology and Geothermal Research 149: 263-296

Zebker, H.A.; Goldstein, R.M. (1986) Topographic Mapping From Interferometric Synthetic Aperture Radar Observations. Journal of Geophysical Research 91 (B5): 4993 - 4999

Zebker, H.A.; Madsen, S.N.; Martin, J.; Wheeler, K.B.; Miller, T.; Lou, Y.; Alberti, G.; Vetrella, S.; Cucci, A. (1992) The TOPSAR Interferometric Radar Topographic Mapping Instrument. IEEE Transactions on Geoscience and Remote Sensing 30 (5): $933-939$

Zeigler, P. A.; Cloetingh, S. (2004) Dynamic processes controlling evolution of rifted basins. Earth-Science Reviews 64: 1-50 


\section{APPENDIX I: Gravity}

This appendix contains information on gravity methods and density analysis that have been conducted during this thesis. Appendix I supplements information presented in Chapter 2.

\subsection{Survey methodology}

Field observations were undertaken by the author and Dhiresh Hansaraj between the $23^{\text {rd }}$ and 27th April 2006, and the author and Daniel Bassett on the 16th December 2006 using a Lacoste and Romberg gravimeter (serial number G179). The calibration of the gravimeter had been updated prior to each survey by members of the geophysics department at Victoria University of Wellington. The location and height of each observation was established with a Leica Real-Time Kinematic (RTK) differential GPS system in both real-time and post-processing mode using the New Zealand Geodetic Datum 2000 trig point Waimangu for both surveys.

During the survey 108 new gravity stations were established and tied to Reporoa gravity station 156 (E2801549 N6302170 height 295 m (MSL) 979976.414 mGal), which is part of the New Zealand Primary Network (Table 6.1) [Robertson \& Reilly, 1960]. The daily determination of instrumental drift included the occupation of the Primary Gravity Network station at the beginning and end of each day and by looping (e.g. repeat readings of previously measured stations). Observations were made along roads, both public and forestry, at 1-2 km spacing. Permits for Whaka and Tarawera forests were obtained from Kaingaroa Timberlands and Hancock Forest Management (NZ) Limited, respectively. An area in Tarawera Forest inaccessible in April 2006 due to logging activities was completed by the survey of the $16^{\text {th }}$ December 2006. Surveying of eastern margin of Okataina Caldera was restricted to the south-eastern Tarawera Forest blocks due to logging of north-eastern blocks north of Tarawera River.

\subsection{Data Reduction}

The gravimeter observations were corrected for tidal effects of the Sun and Moon before solving for the instrumental drift and detection of any jumps or tares in the observations. The corrected gravity values have a standard error of approximately \pm 0.02 mGal. No instrument tares were recorded during either of the survey periods. The tying of each survey to the Primary Gravity Network Station at Reporoa ensures the gravity 
values are compatible with historical data within the GNS Science New Zealand Land Gravity Database.

Free-air and Bouguer anomalies have been calculated using the method described in Reilly [1970, 1972 and references therein]. Using the 1960 International formula for the external gravity field, the Free-air anomaly $\Delta g_{\mathrm{F}}$ is found from the observed gravity $g$ at latitude $\varphi$ and height $h(\mathrm{~km})$ by:

$$
\Delta g_{\mathrm{F}}=\mathrm{g}-\gamma_{\mathrm{h}}
$$

Where

$\gamma_{\mathrm{h}}=978049+5149.34 \sin ^{2} \varphi+22.83 \sin ^{4} \varphi+0.12 \sin ^{6} \varphi+h\left(-308.777+0.452 \sin ^{2} \varphi\right)+$ $h^{2}\left(0.0727-0.0002 \sin ^{2} \varphi\right) \mathrm{mGal}$

The Bouguer anomaly $\Delta g_{\mathrm{B}}$ is found from

$$
\Delta g_{\mathrm{B}}=\mathrm{g}-\gamma_{\mathrm{B}}
$$

$\gamma_{\mathrm{B}}$ is calculated by the addition of the gravitational effect of topography (i.e. departure of the physical surface from the geoid) to $\gamma_{\mathrm{h}}$ out to a radius of $166.7 \mathrm{~km}$ for each station. Densities of $2670 \mathrm{~kg} / \mathrm{m}^{3}$ and $1030 \mathrm{~kg} / \mathrm{m}^{3}$ are assumed for the topography (rock) and water respectively.

$$
\gamma_{\mathrm{B}}=\gamma_{\mathrm{h}}+b(h)+\Delta b_{1}+\Delta b_{2}+c
$$

Where $b(h)$ is the attraction of a circular plate of rock with a radius of $21.944 \mathrm{~km}$ and thickness $h$ equal to the height of the station above sea level. The terms $\Delta b_{1}$ and $\Delta b_{2}$ are the inner (Hammer zone B-D) and outer terrain corrections (Hammer zone E-M), respectively and c is the complete topographic correction from $21.944 \mathrm{~km}$ (Hammer zone M) to $166.7 \mathrm{~km}$ after Reilly [1970].

The correction for nearby topography out to Hammer D zone (170 m), or the inner terrain correction, was determined in the field by visual estimation of the height of the terrain relative to each observation point. The outer terrain corrections (Hammer E$\mathrm{M})$ were computed in the reduction stage using a $10 \mathrm{~m}$ digital terrain model and range in magnitude from $0.1 \mathrm{mGal}$ in relatively flat areas to $2.75 \mathrm{mGal}$ in locations with steep topography. Due to the highly variable and often steep volcanic terrain, the average terrain correction for the 108 measurements approaches $1 \mathrm{mGal}$.

\subsection{Sources of Error}

Three main sources of error in the gravity observations have been identified; observational, elevation, and terrain estimation. Observational error for the calculated gravity at each station is a function of the gravimeter dial reading and the time of 
measurement. Time observations are used for calculating instrumental drift and the diurnal gravity variation. The LaCoste and Romberg gravity meter dial divisions represent approximately $0.01 \mathrm{mGal}$ per division, repeat readings at stations typically produced residuals with standard deviation of $\pm 0.02 \mathrm{mGal}$.

The elevation above sea-level of each gravity station was measured by a Leica SR530 Real-Time Kinematics Global Positioning system. An orthometric height for each gravity station was established using the New Zealand Geodetic Datum 2000 trig point Waimangu (Geodetic code 3073) NZMG E2806294.38 N6318297.52 orthometric height $467.75 \mathrm{~m}$ ). This geodetic mark has a $3^{\text {rd }}$ order control on both horizontal and vertical axes on the order of $\pm 0.01 \mathrm{~m}$. Coordinate quality is typically of the order of $\pm 0.05 \mathrm{~m}$ for well resolved stations ranging to $\pm 0.5 \mathrm{~m}$ for stations with limited satellite coverage. The uncertainty in the gravity arising from errors altitude is $\pm 0.1 \mathrm{mGal}$.

Terrain estimation is potentially the largest and least quantifiable error in the calculation of Bouguer gravity anomalies. For each station, the terrain in a $170 \mathrm{~m}$ radius (Hammer zone D) was estimated in the field. Terrain corrections to a radius of 21.944 km (Hammer zones E-M) are calculated from a $10 \mathrm{~m}$ digital terrain model derived from Land Information New Zealand 1:50 000 topographic map sheets assuming a density of $2670 \mathrm{~kg} / \mathrm{m}^{3}$ for the topography. All terrain corrections for topography were calculated using GNS Science programs NEAR_TERRAIN and TERRAIN.

The effect of a topographic feature on any gravity observation is inversely proportional to the distance from the observation point. For example, an error in estimate of $50 \mathrm{~m}$ in elevation of a compartment in Hammer zone H (1530-2615 m) will result in an error in the terrain correction of $0.005 \mathrm{mGal}$, whereas an error in the elevation estimate of $50 \mathrm{~m}$ for Hammer zone C (16.6-53.3 m) will result in an error of $\sim 0.25 \mathrm{mGal}$. Errors in terrain correction for the outer Hammer zones will tend to cancel one another out, while consistent over or under estimation in near zone elevation variation will produce estimated terrain correction errors of approximately $\pm 0.3 \mathrm{mGal}$.

\subsection{GNS Land Gravity Database}

Gravity data collected as part of this thesis was complemented with existing information from the GNS Land Gravity Database. The principal source of error between the two datasets is the method of altitude determination. The majority of the pre-existing gravity data set have elevations derived from barometric levelling. The discrepancy in orthometric elevation between the RTK GPS and barometric methods is highlighted for a station reoccupied during this survey. Station 7014 (this study) and 2191 (historic data) 
have a very similar terrain correction $(\sim 0.3 \mathrm{mGal})$ and a difference in calculated Bouguer anomalies of $1.5 \mathrm{mGal}$, while the difference in the height of the stations above sea level is $8.8 \mathrm{~m}$ (equating to $2.71 \mathrm{mGal}$ ). As discussed in Chapter 2, all station altitudes in the GNS Land Gravity Database were checked against a digital elevation model with a $10 \mathrm{~m}$ cell size resolution and those station altitudes that differ from the model $>20$ m excluded from this study. For example, manual inspection of the data identified that station 2411 of the NZ Land Gravity Database has a recorded height of $55.7 \mathrm{~m}$ whereas the altitude of the topography and adjacent gravity stations is $\sim 320 \mathrm{~m}$ above sea-level.

\subsection{Comparison with previous gravity studies}

Rogan [1980] collected 116 gravity stations across the OVC (Fig. 6.1). In contrast to using a Primary NZ Gravity Network station to tie the survey to a known absolute gravity value, Rogan [1980] used a mean reference level of the gravitational field for the area. The mean reference level was tied to the absolute field using a scalar. This scalar is added to the gravity values to provide absolute values. This reduction method is inconsistent with the New Zealand Land Gravity Database and the data are therefore not included in the regional dataset. As Rogan's gravity data is internally consistent it can however be used for the analysis of gravity gradients over areas where lateral density changes occur (e.g. caldera margins) and gravity data is sparse (Fig. 6.2).

As the reduction method of Rogan [1980] is tied to New Zealand Land Gravity stations the data has been recalculated to residual anomalies using the regional of Stern [1979] to compare with the results of this study (Fig. 6.1). The recalculated minimum residual gravity anomaly of Rogan [1980] has a similar north-south elongation direction and is slightly larger than the one used in this study due to two stations on the western margin of the caldera. The $-45 \mathrm{mGal}$ contour used to define the inner collapse structure of the caldera [Chapter 2] is however very similar in the two data sets (Fig. 6.2). 
Fig. 6.1. Residual gravity map of the Okataina Volcanic Center (OVC). (A) Gravity data are from new gravity measurements (filled circles) [this study] and the GNS Land Gravity Database (crosses) reduced to Bouguer anomalies using the method of Reilly [1972]. A density of $2670 \mathrm{~kg} / \mathrm{m}^{3}$ was used for the Bouguer and Terrain corrections. Residual gravity anomalies have been obtained by the removal of the regional field of Stern [1979] from the Bouguer anomaly data. (B) Gravity data from Rogan [1980] reduced to Bouguer anomalies using the method of Reilly [1972] as above. Rogan used a reduction method to obtain absolute gravity values inconsistent with the GNS Land Gravity Database (refer to text) and therefore cannot be incorporated into this study with confidence. Note the similarity in size and shape of the $-45 \mathrm{mGal}$ contour between the two data sets.
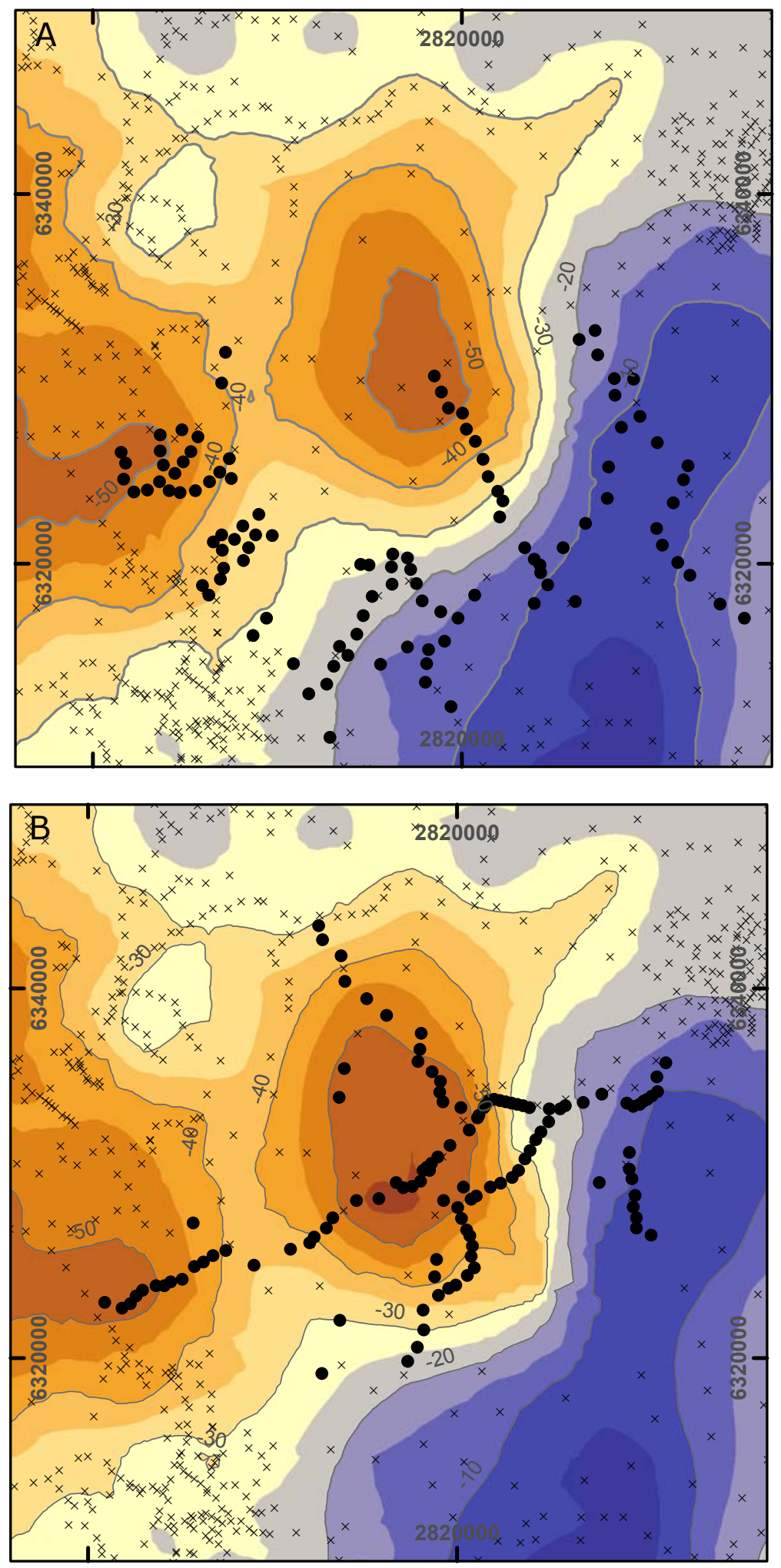
Fig. 6.2. Residual gravity anomaly map of the Okataina Volcanic Center (OVC). (A) Residual gravity data are from new gravity measurements [this study] and the GNS Land Gravity Database (crosses) (refer to Fig. 6.1 for reduction method). Stations used in $2 \frac{1}{2} \mathrm{D}$ gravity modelling (filled circles) and inferred caldera boundaries (thick black lines) used to define inner collapse structure (B) Residual gravity data from Rogan [1980] and GNS Land Gravity Database (Fig. 6.1) for comparison with (A). The location of the inferred structural boundary approximates the -45 mGal contour in both models. Numbers indicate gravity gradients $(\mathrm{mGal} / \mathrm{km})$ in A and B and shows steep gradients on segments of the eastern and western caldera boundaries.
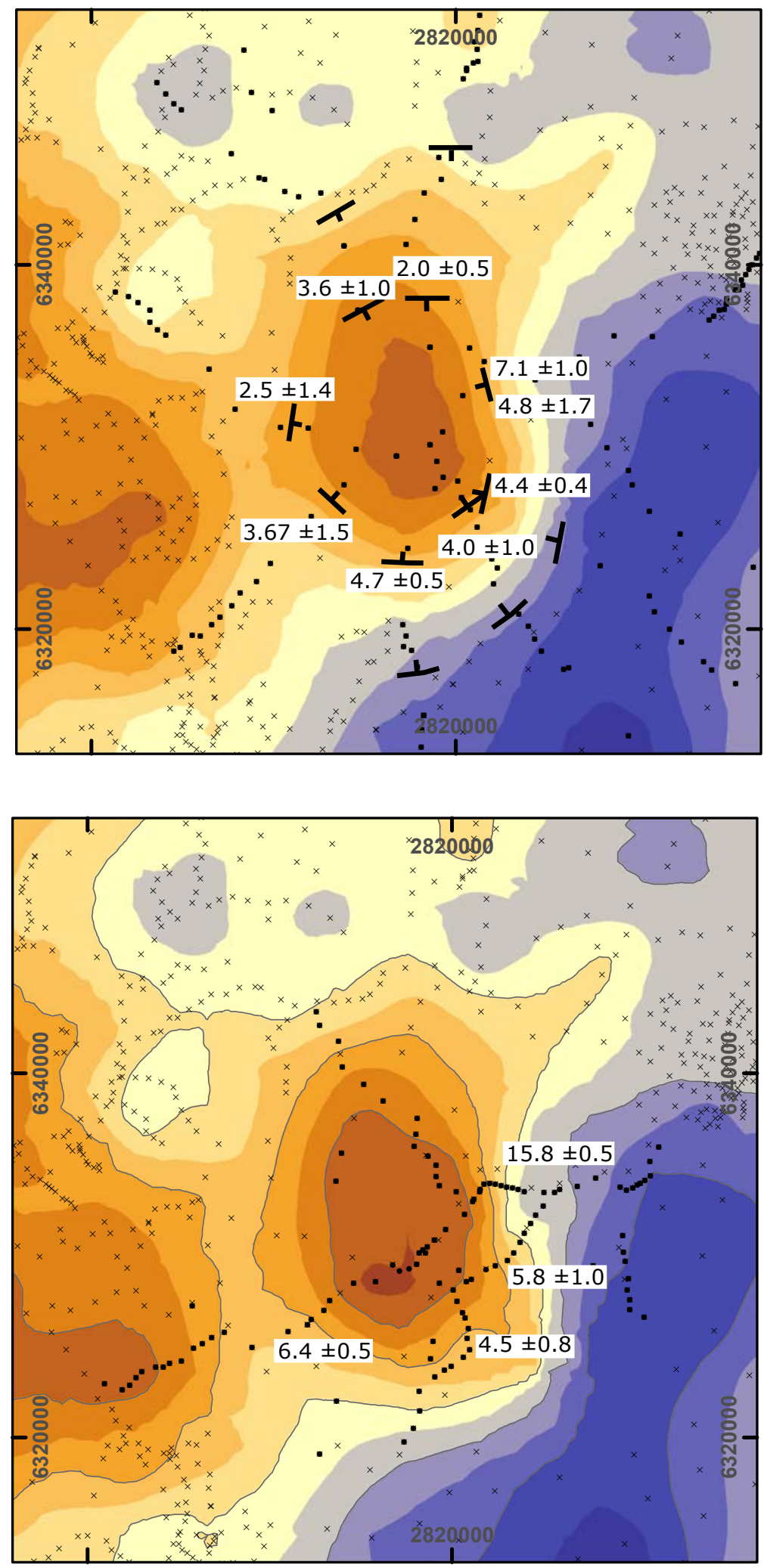


\subsection{Density analysis}

Composition and density verses depth data from TVZ geothermal regions are split out into individual compositions (Fig. 6.3), 'hot' verses 'cold' drill-holes (Fig. 6.4), and individual drill-holes (Fig. 6.5) to highlight the variation in density and composition with depth. The main feature to note is the general increasing density with depth.

\subsubsection{Observed verses model density profiles}

Simple 1D-gravity models estimating top basement (e.g. a density of $2670 \mathrm{~kg} / \mathrm{m}^{3}$ ) are derived from the exponentially increasing density with depth function of Cordell [1973] (Fig. 2.5). The details of modelling are detailed in section 2.2.3. A comparison between observed TVZ drill-hole densities and those calculated for gravity modelling shows calculated curves fall within the range of observed drill-hole and material densities with depth (Fig. 6.3). These model curves, derived from independent geophysical constraints to basement (Table 6.2) are consistent with TVZ density data.

A comparison between a 'hot' geothermal drill-hole and a 'cold' drill-hole, Kawerau and Tauhara respectively (Fig. 6.4), shows that the modelled density with depth (preferred model Fig. 2.5) has a similar density profile and curvature as the mean Tauhara data. While the comparison between these two drill-holes $85 \mathrm{~km}$ apart is not strictly justified, the similarity between volcanic compositions, depth and location on the eastern margin of the TVZ, allow these drill-holes to be reviewed. The OVC shows evidence for geothermal activity along the Tarawera linear vent zone however the majority of the caldera complex could be considered 'cold' or predominantly unaltered by geothermal activity [Bibby et al., 1995; Nairn, 2002]. 


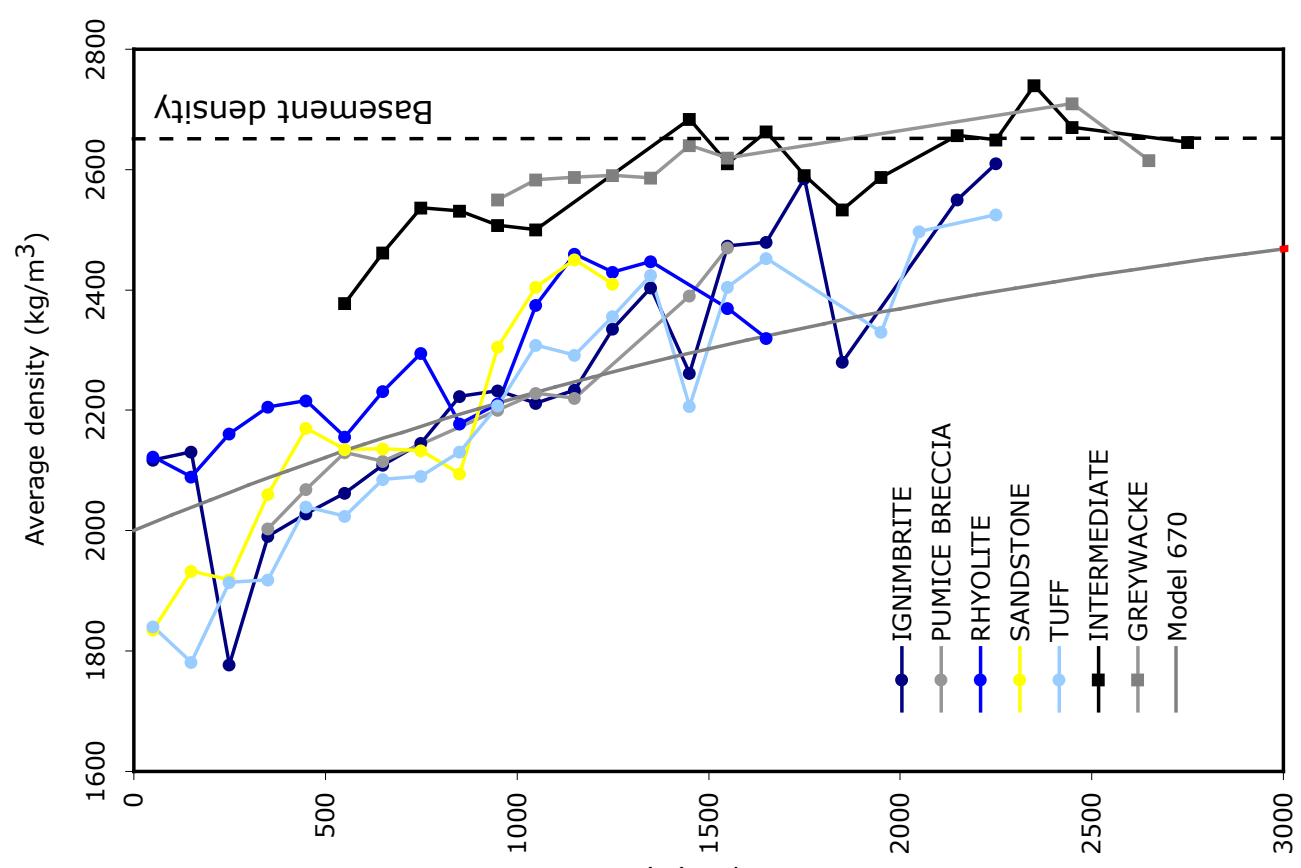

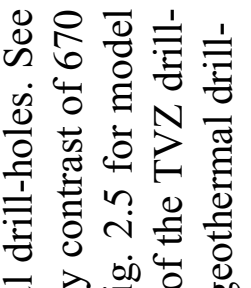

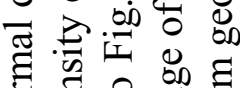

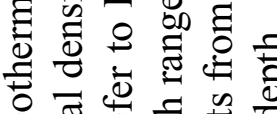
可䜦

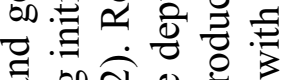
สิ ¿ ॠ क घ르릴 记㐫分. 융 : N

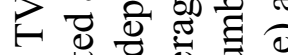
๖ี

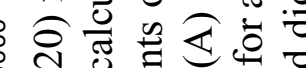
๓

(w) प7də0 규 플 ॥.

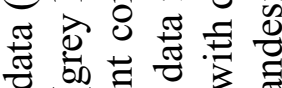

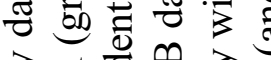

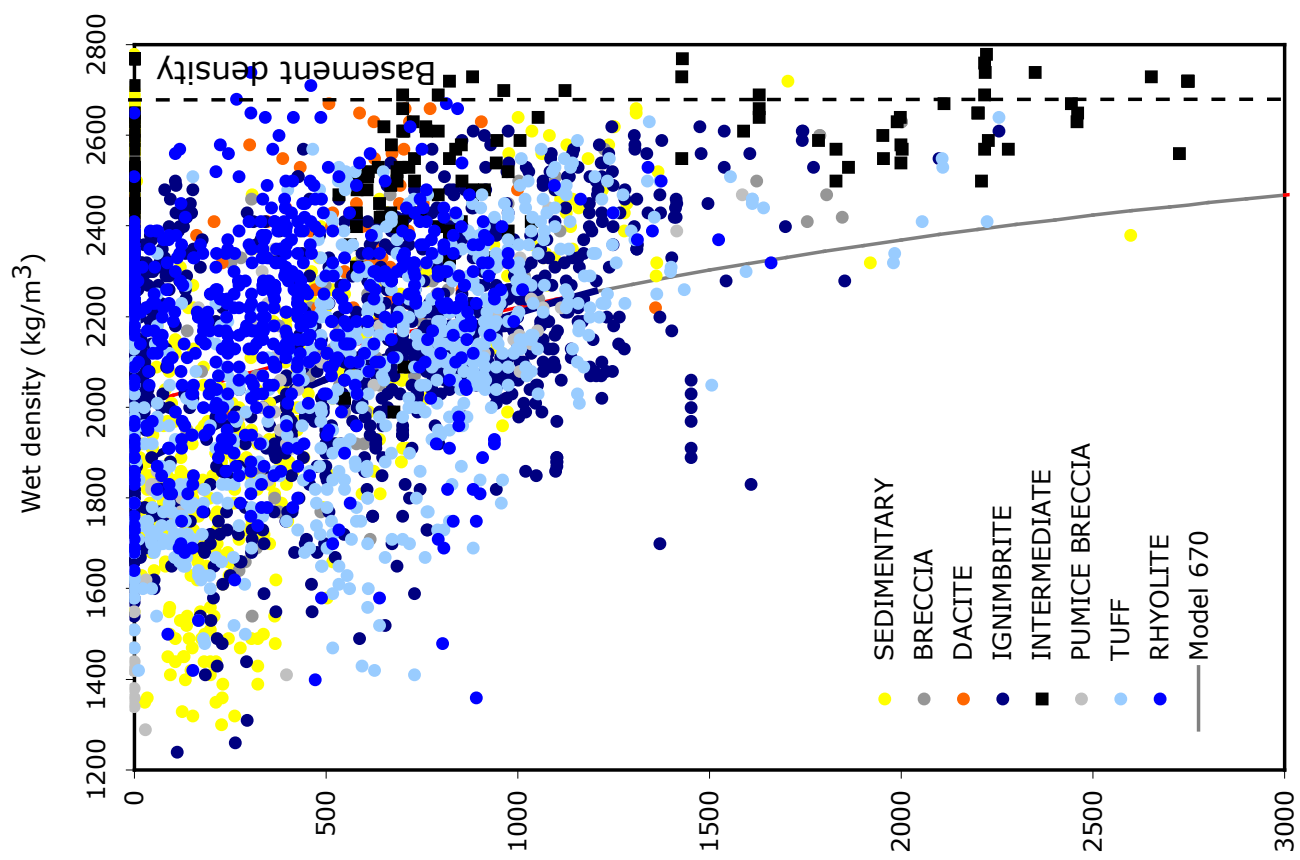

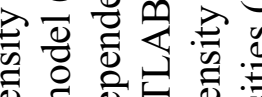

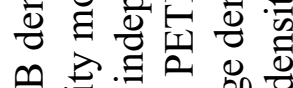

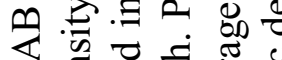

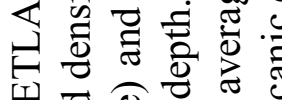

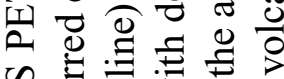
公造焉吾 出的要 ¿

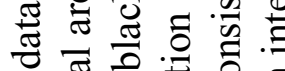
플 司

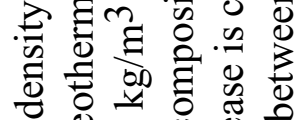
엉

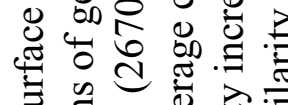

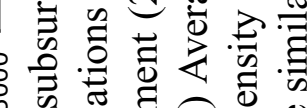
$N$ 氖包 $\varangle$

(u) प7də0

> ஸे थ

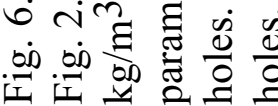




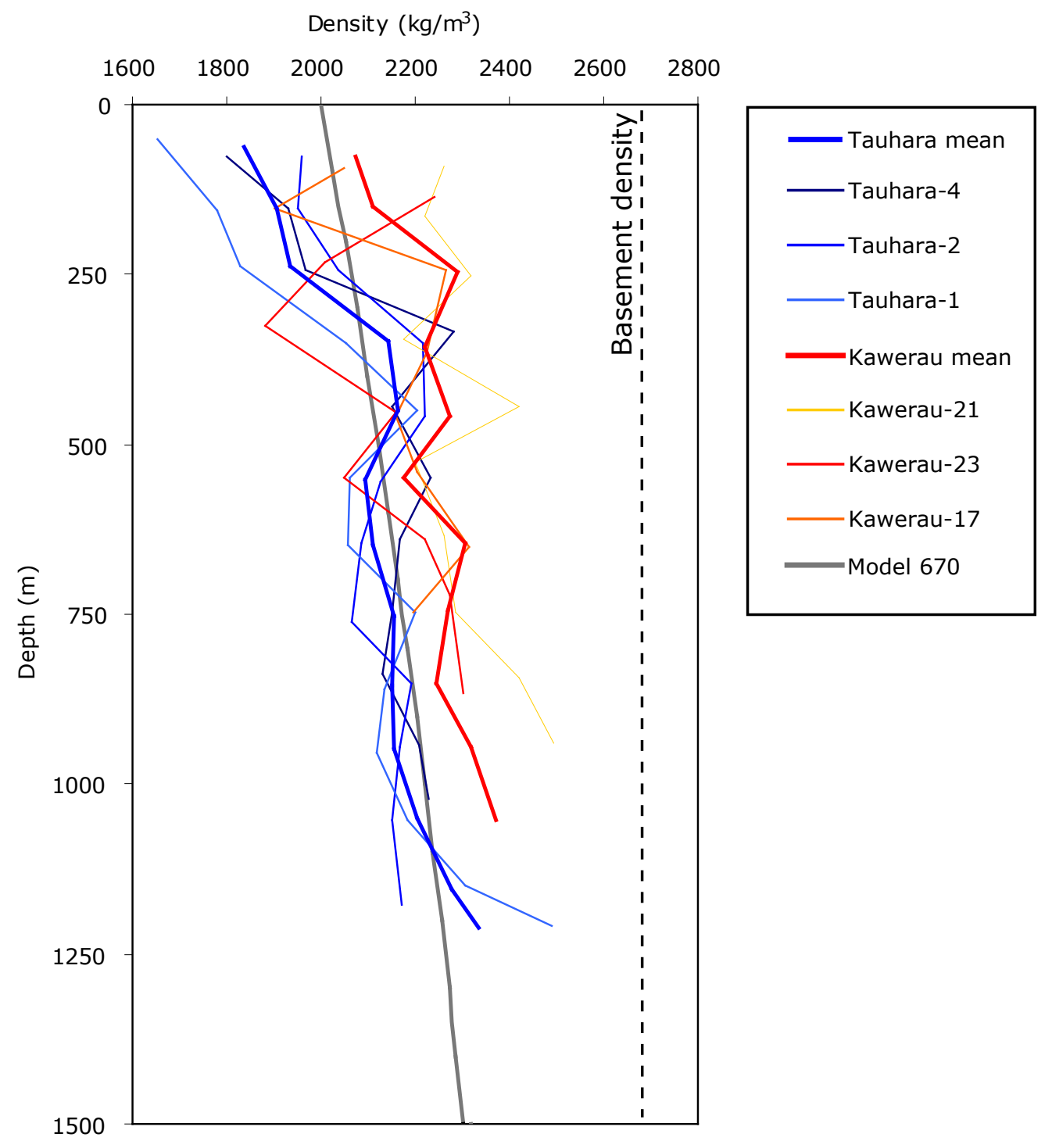

Fig. 6.4. Average density with depth for Kawerau and Tauhara drillholes. Basement compositions (i.e. andesite and greywacke) removed to compare low density volcanic compositions. Drillhole densities averaged in $100 \mathrm{~m}$ bins for Tauhara and Kawerau (thick blue and red lines respectively). The Kawerau geothermal drillholes (e.g. Ignimbrite, Tuff, Quaternary sediments) $15 \mathrm{~km}$ northeast of the OVC shows uniformly higher mean densities $\left(\sim 200 \mathrm{~kg} / \mathrm{m}^{3}\right)$ than the 'cold' Tauhara drillhole [Stern, 1985]. The potential for densification within geothermal drillholes and hence any depth analysis derived from density data may be biased towards higher densities at depth than exist beneath the majority of the 'cold' TVZ. Density with depth models used in gravity modelling (Fig. 2.5) are consistent with the mean Tauhara drillhole density profile. Data: GNS PETLAB Database. 


\begin{tabular}{|l|}
\hline KEY \\
- Sediments \\
- Tuff/Breccia \\
- Racite \\
- Andesite \\
- Greywacke \\
\hline
\end{tabular}

Fig. 6.5a. Individual TVZ geothermal drill-hole stratigraphy and density. Densities of volcanic materials typically decreases with depth, however individual drill-hole data show a high degree of variability due to composition and/or alteration effects (Fig. 6.4)

[Stern, 1987]. Densities (grey line) from the preferred exponen-

tially decreasing density contrast with depth model (Fig. 2.5) for

reference. Data: GNS PETLAB Database. Refer to Table 6.3 for location and collector information.
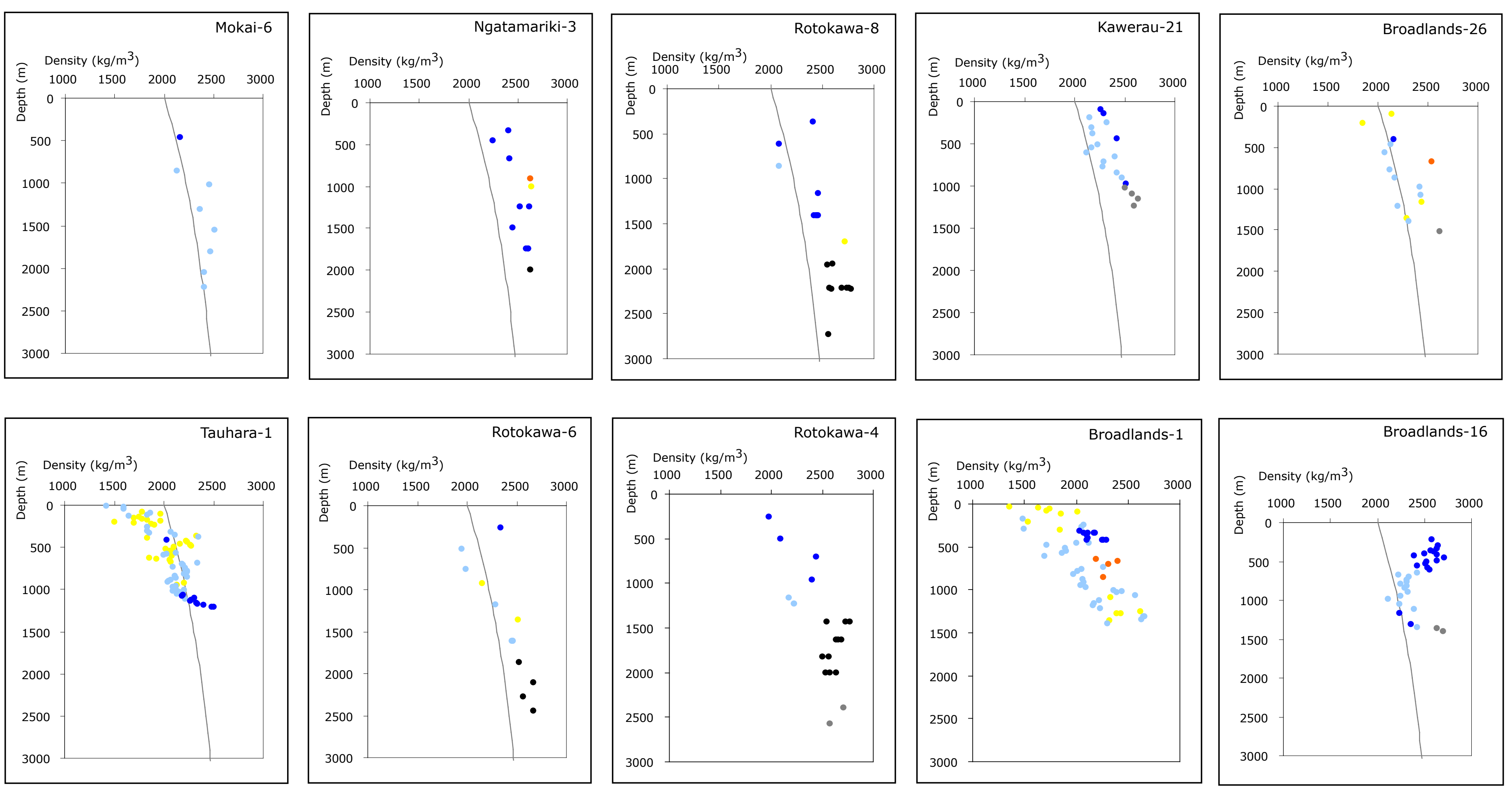


\begin{tabular}{|l|}
\hline KEY \\
- Sediments \\
- Tuff/Breccia \\
- Racite \\
- Andesite \\
- Greywacke \\
\hline
\end{tabular}

Fig. 6.5b. Individual TVZ geothermal drill-hole stratigraphy and density. Densities of volcanic materials typically decreases with depth, however individual drill-hole data show a high degree of variability due to composition and/or alteration effects (Fig. 6.4)

[Stern, 1987]. Densities (grey line) from the preferred exponen-

tially decreasing density contrast with depth model (Fig. 2.5) for

reference. Data: GNS PETLAB Database. Refer to Table 6.3 for location and collector information.
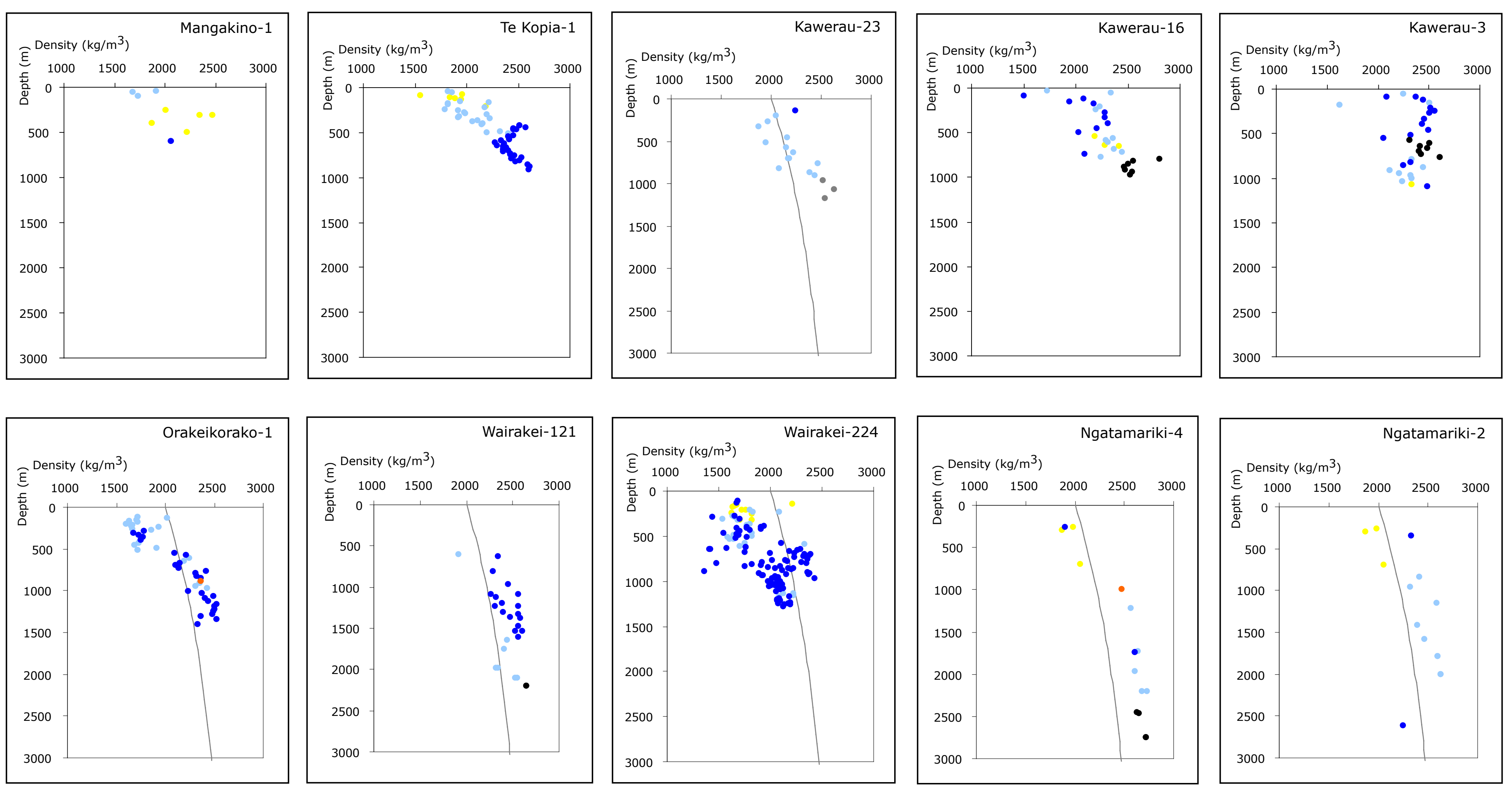
The Kawerau geothermal drill-holes are $15 \mathrm{~km}$ northeast of the OVC is the closest location for subsurface density information for the OVC. The Tauhara drill-hole density data includes volcanic products essentially unaltered by geothermal activity [Stern, 1985]. A uniform increase in density $\left(\leq 200 \mathrm{~kg} / \mathrm{m}^{3}\right)$ with depth is observed between the Kawerau and Tauhara volcanic products and is attributed to secondary densification effects. Individual TVZ drill-holes are also compared against the preferred model density profile (Fig. 6.5). Mokai-6 and Rotokawa-8 most closely resemble the preferred model density profile whereas the majority of other deep drill-holes (>1.5 km) are typically $200-300 \mathrm{~kg} / \mathrm{m}^{3}$ (or $\sim 10 \%$ ) denser than the model profile. This may in part be due to densification effects (Fig. 6.4) [Stern, 1985].

Simple gravity modelling undertaken to investigate the minimum gravity anomaly of simple geometric objects with dimensions similar to those of the OVC shows that the majority of the anomaly can be accounted for by low density infill (Fig. 6.6). The minimum gravity associated with a cylinder extending from the surface to a depth (L) (Fig. 6.6a) for single uniform density contrasts are compared with those with an exponentially decreasing density contrast with depth. The uniform density contrast has an approximately $-5 \mathrm{mGal}$ lower gravity anomaly than the preferred exponentially decreasing density contrast model $\left(670 \mathrm{~kg} / \mathrm{m}^{3}\right)$ at $2 \mathrm{~km}$ depth. This suggests that gravity modelling with uniform density contrasts under estimate basement depths. Comparison of the preferred model density profile (Fig. 6.7) with a model density profile from the Silent Canyon Caldera complex [Ferguson et al., 1994] (constrained by seismic refraction studies, drill-hole, and outcrop data) show a good fit despite the density variability with depth. The composition of the materials between the two volcanic centres is considered to be similar (e.g. welded ignimbrite, tuff, and lavas). 


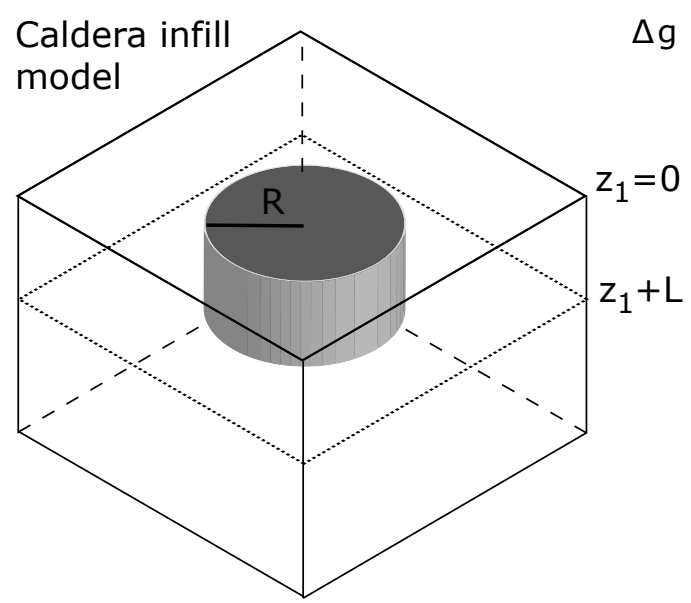

$\Delta \mathrm{g}_{\min }=2 \pi \mathrm{G} \Delta \rho\left[\left(\mathrm{b}_{1}-\mathrm{b}_{2}\right)+\mathrm{L}\right]$

$b_{1}=\sqrt{ }\left[\left(z_{1}^{2}+R^{2}\right) \quad b_{2}=\sqrt{ }\left[\left(z_{1}^{2}+L\right)+R^{2}\right]\right.$

Where $\mathrm{G}$ is the Gravitational Constant, $\Delta \rho$ is the density contrast, $R$ is the radius and $L$ is the height of the cylinder.

Cylindrical magma chamber model

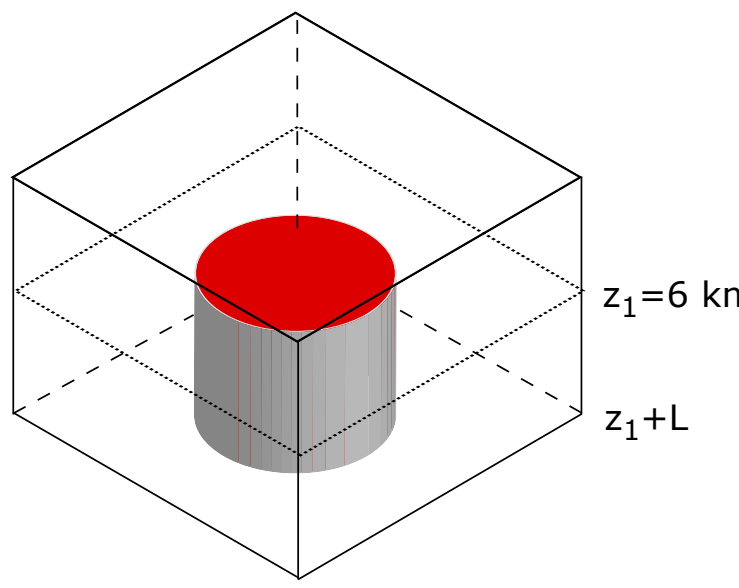

Spherical magma chamber model

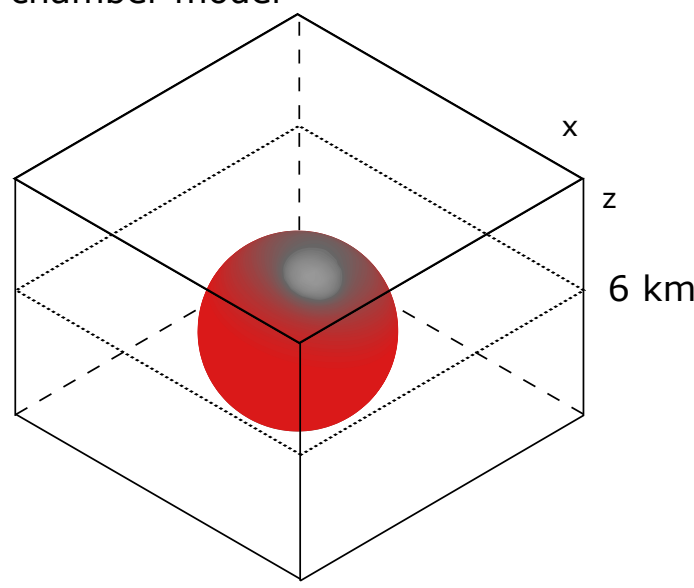

$\Delta g_{\min }=\left(4 / 3 \pi R^{3} \Delta \rho G z\right) /\left(x_{2}+z_{2}\right)^{3 / 2}$

Where $G$ is the Gravitational Constant, $\Delta \rho$ is the density contrast, $R$ is the radius and $z$ is the depth to the centre of the sphere.

Fig. 6.6a. Gravity anomaly for density uniform and exponentially decreasing density contast for cylinder with $10 \mathrm{~km}$ radius representing lowdensity infill of caldera collapse structure. Caldera infill depths and maximum residual gravity anomaly from this study, Carle \& Goldstein [1987], and Fergusion et al. [1994].

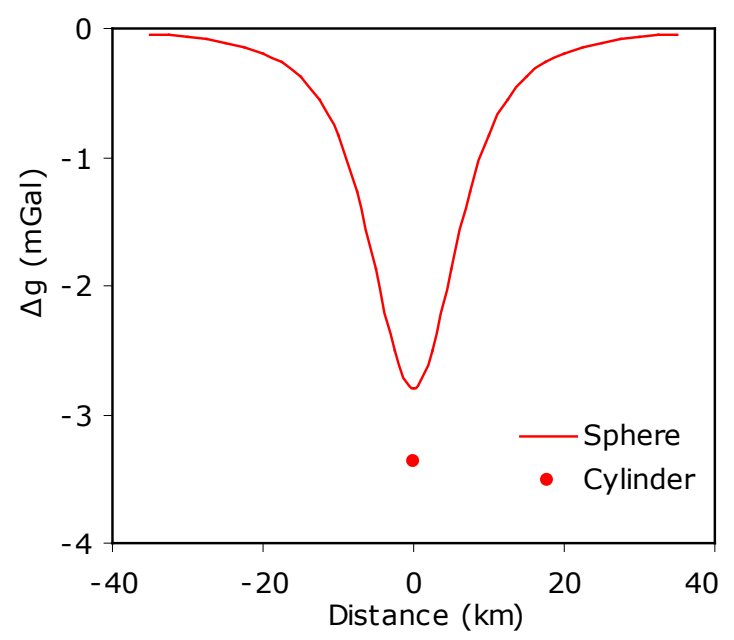

Fig. 6.6b. Gravity anomaly for buried cylinder and sphere with top depth constrained to $6 \mathrm{~km}$. Both objects have a radius $(\mathrm{R})$ of $4 \mathrm{~km}$, a total volume of $113 \mathrm{~km}^{3}$ (density contrast of $-300 \mathrm{~kg} / \mathrm{m}^{3}$ ). Buried cylinder gravity minimum anomaly calculated as above. Note that density contrast estimated is maximum for crystal rich rhyolitic mush zone with partial melt [e.g. Bachmann et al., 2007]. Gravity contribution of the pluton to the overall gravity anomaly for the caldera is the same as estimated model error. 


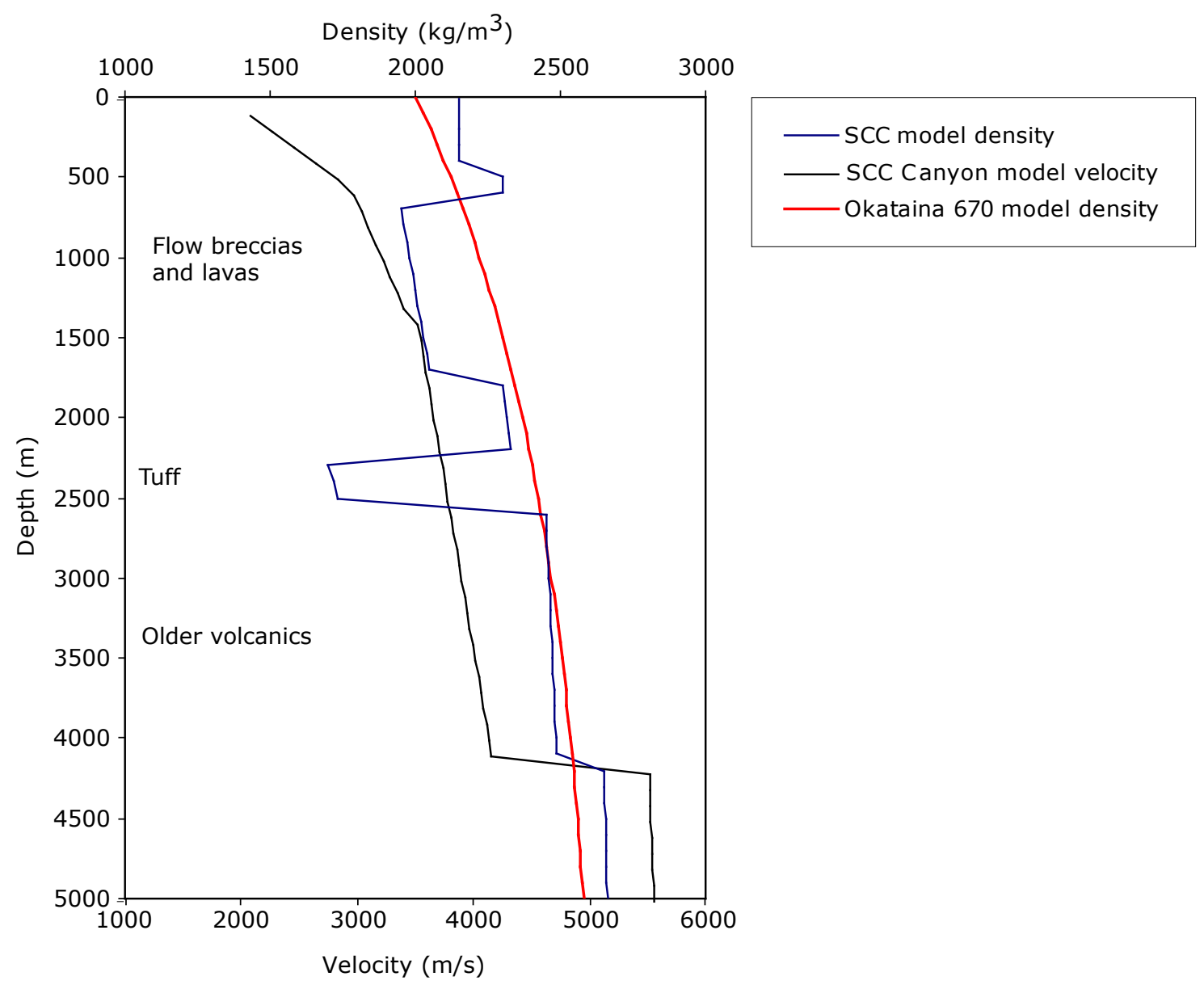

Fig. 6.7. Density comparison between Okataina and Silent Canyon Caldera complexes. Silent Canyon Caldera complex (SCC) has a similar residual gravity anomaly as the Okataina Caldera (-55 mGal), well established stratigraphy, drill-hole data up to $4 \mathrm{~km}$, and seismic refraction velocities across the volcanic centre. The gravity and refraction models of the caldera have a consistent $4 \mathrm{~km}$ deep basement that show a piecemeal collapse style along rift faults infilled with low density volcanic products [Ferguson et al., 1994]. Long Valley Caldera is of a similar size and shape to Okataina. Similar densities to those used for Okataina $2 \frac{1}{2} \mathrm{D}$ gravity modelling $\left(2150\right.$ and $2350 \mathrm{~kg} / \mathrm{m}^{3}$ ) are used for Long Valley caldera 3D gravity modelling (including drillhole constraints) [Carle \& Goldstein, 1987]. The Long Valley 3D gravity model has $2.8 \mathrm{~km}$ of caldera infill associated with a $-50 \mathrm{mGal}$ residual gravity anomaly. While low density plutons are required at depths of $7 \mathrm{~km}$ for some areas of the Long Valley Caldera, the minimum gravity low can be accounted for by volcanic infill alone. 
A Initial surface density contrast $670 \mathrm{~kg} / \mathrm{m}^{3}$

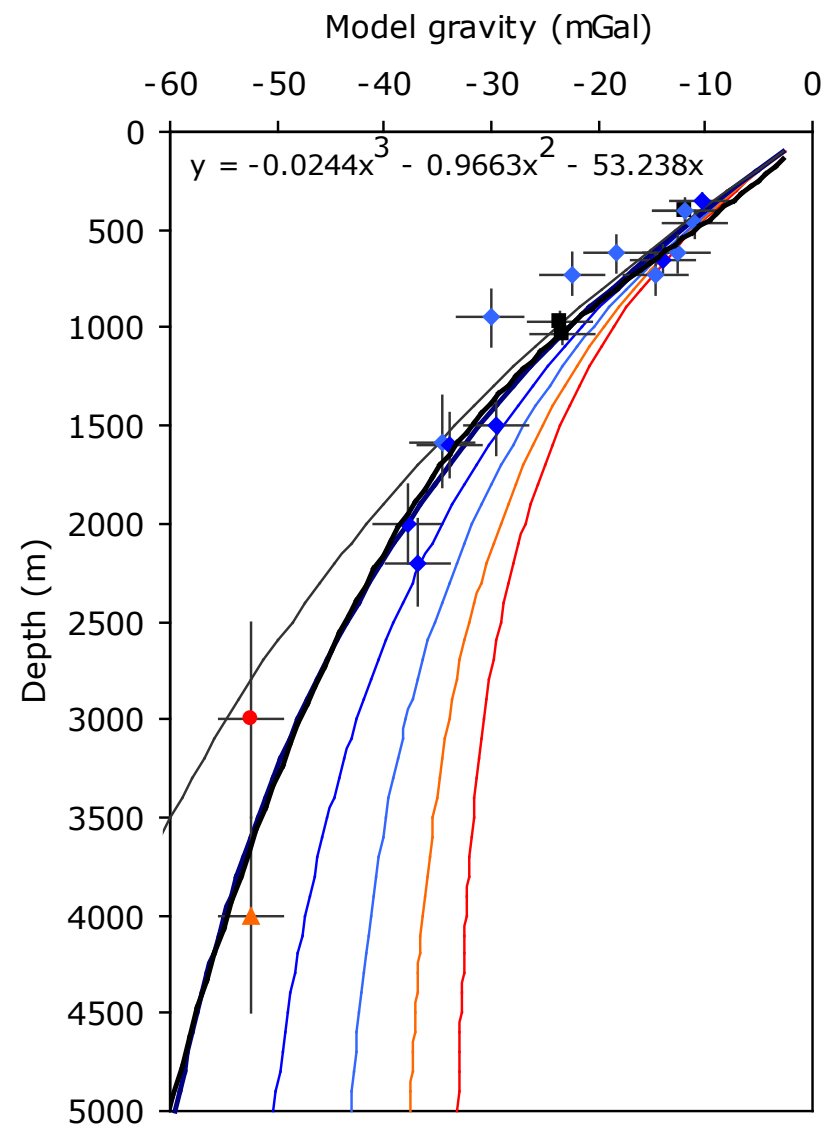

B

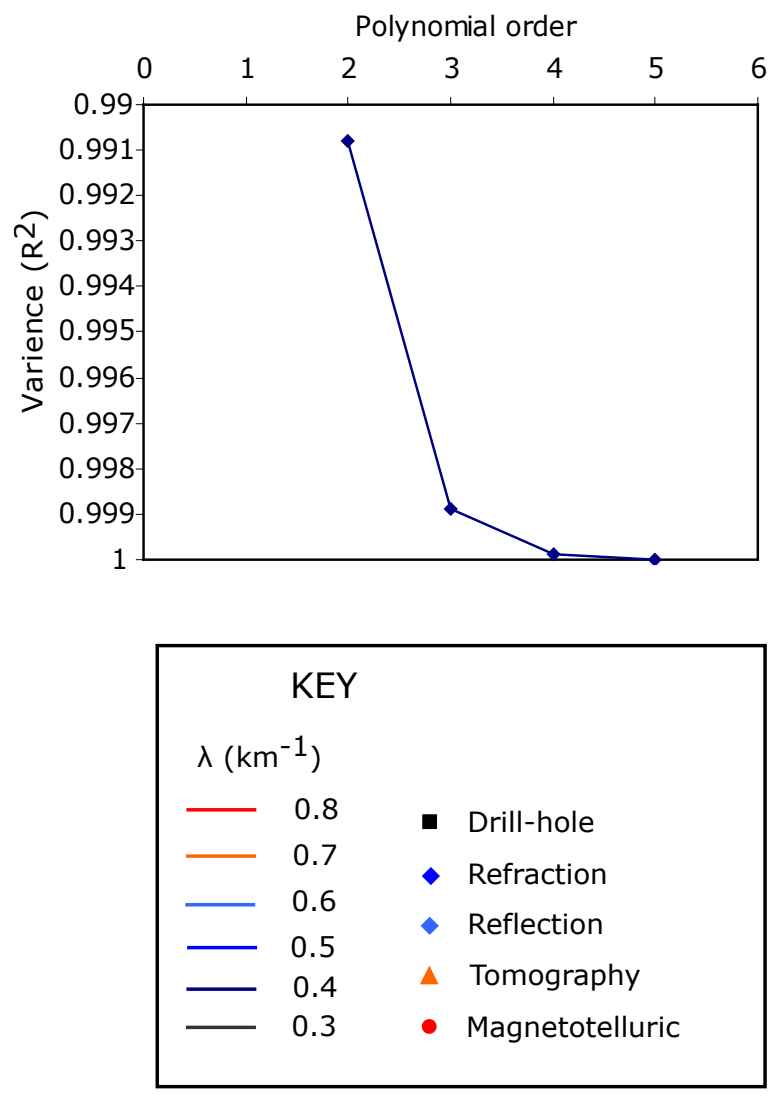

Fig. 6.8. Gravity verses depth function derived from 1D gravity modelling and independent depth to basement constraints (Table 2.2). (A) Model gravity depth curve for an initial surface density contrast of $670 \mathrm{~kg} / \mathrm{m}^{3}$ (Fig. 2.5) showing fit of 3rd order polynomial to curve with depth increment of $0.4 \mathrm{~km}^{-1}$. (B) Comparison of varience verses order of polynomial fitting curve in (A). The fit of a fourth order polynomial has only a small difference in the R2 fit for the curve. (C) Map showing the difference in depth contour values determined from 3rd order (red lines) and 4th order (blue lines) polynomials. For a first order estimate to basement the difference is negligible. Independent depth to basement locations (Table 6.2) shown for reference.

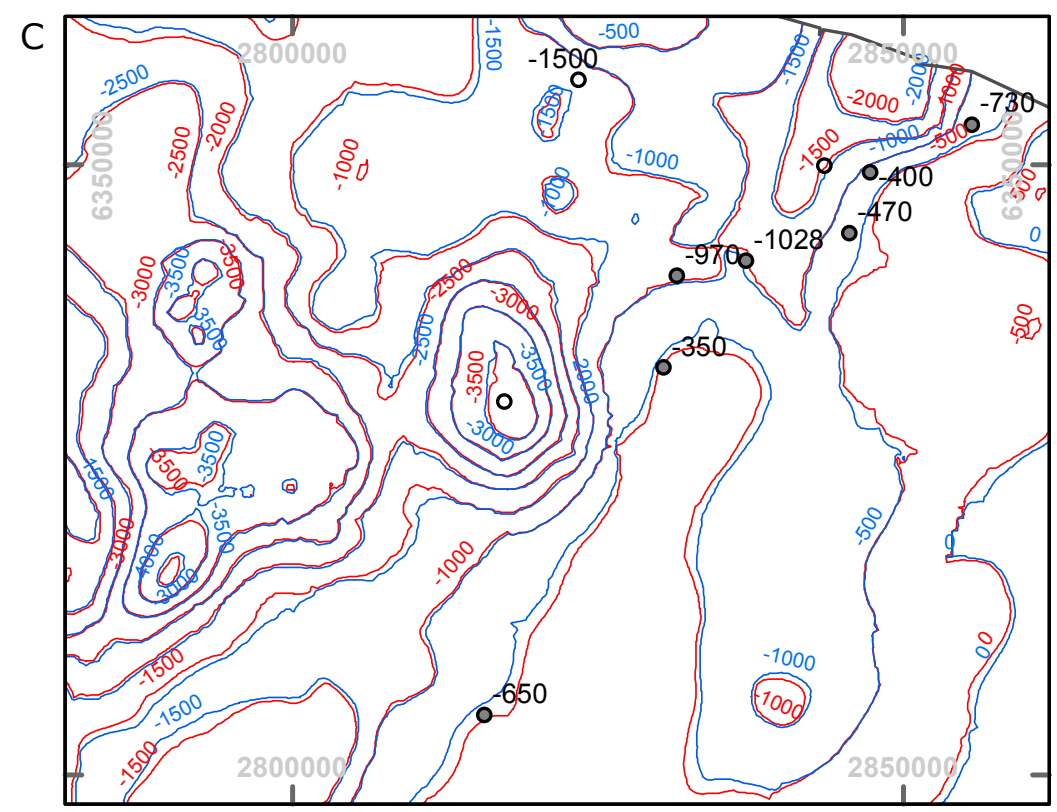


Table 6.1: Summary of Gravity data acquired during this study. Header information: Station number; X and Y, NZMG East and North coordinates; Height, metres above sea-level; Gravity, Absolute gravity minus 975000 in $\mu \mathrm{N} / \mathrm{kg}$; Date, yy mm dd; Inner Terrain, Hammer zone B-D; Outer Terrain, Hammer zone E-M; FAA; Free-air Anomaly; BA, Bouguer Anomaly; ISA, Isostatic Anomaly; Regional, Calculated regional anomaly of Stern [1979]; Residual, BA-Regional. Note all gravity reported in $\mu \mathrm{N} / \mathrm{kg} .1 \mu \mathrm{N} / \mathrm{kg}=0.1 \mathrm{mGal}$.

\begin{tabular}{|c|c|c|c|c|c|c|c|c|c|c|c|c|}
\hline Station & $x$ & $Y$ & Height & Gravity & Date & $\begin{array}{l}\text { Inner } \\
\text { Terrain }\end{array}$ & $\begin{array}{l}\text { Outer } \\
\text { Terrain }\end{array}$ & FAA & BA & ISA & Regional & Residual \\
\hline 7001 & 2806321 & 6318268 & 466.6 & 49392.3 & 60423 & -2.2 & -4.3 & 536.9 & 37.1 & 189.1 & 394.22 & -357.12 \\
\hline 7002 & 2819816 & 6317008 & 442.6 & 49597.6 & 60423 & 0 & -2 & 662.3 & 184.6 & 325.7 & 328.12 & -143.52 \\
\hline 7003 & 2818882 & 6317368 & 444.2 & 49581.5 & 60423 & 0 & -2 & 653.7 & 174.2 & 315.1 & 335.57 & -161.37 \\
\hline 7004 & 2817873 & 6317941 & 452.9 & 49546.6 & 60423 & -0.1 & -2.4 & 649.8 & 161.2 & 301.3 & 344.98 & -183.78 \\
\hline 7005 & 2817555 & 6318898 & 445.6 & 49546.9 & 60423 & -0.2 & -4 & 635.1 & 156.2 & 293.4 & 354.23 & -198.03 \\
\hline 7006 & 2817249 & 6319657 & 453 & 49507.4 & 60423 & -0.1 & -5.8 & 624.3 & 138.9 & 273.8 & 361.72 & -222.82 \\
\hline 7007 & 2817088 & 6320265 & 457.3 & 49465.6 & 60423 & -0.3 & -8.5 & 600.5 & 113.3 & 246.2 & 367.30 & -254.00 \\
\hline 7008 & 2816286 & 6320504 & 428.4 & 49504.7 & 60423 & -0.3 & -11.4 & 552.1 & 99.6 & 232.8 & 372.59 & -272.99 \\
\hline 7009 & 2814551 & 6319936 & 360 & 49660 & 60423 & 0 & -7.7 & 491.4 & 110.7 & 248.3 & 375.29 & -264.59 \\
\hline 7010 & 2814980 & 6319883 & 370.3 & 49643.9 & 60423 & 0 & -7.8 & 506.8 & 114.7 & 252 & 373.11 & -258.41 \\
\hline 7011 & 2819099 & 6315778 & 439.9 & 49605.9 & 60423 & 0 & -1.4 & 652.3 & 177.2 & 323.5 & 321.18 & -143.98 \\
\hline 7012 & 2818231 & 6315331 & 438.4 & 49607.1 & 60423 & -0.1 & -1.4 & 645.2 & 171.7 & 320.6 & 321.60 & -149.90 \\
\hline 7013 & 2817093 & 6315474 & 440.3 & 49611.9 & 60423 & 0 & -1.6 & 656.5 & 181.1 & 330.8 & 328.20 & -147.10 \\
\hline 7014 & 2815615 & 6314535 & 450.9 & 49623.8 & 60423 & -0.1 & -2.1 & 693.3 & 206.9 & 361.4 & 327.36 & -120.46 \\
\hline 7015 & 2813839 & 6314990 & 467.8 & 49502.7 & 60423 & -0.2 & -1.4 & 627.4 & 121.4 & 276.5 & 339.14 & -217.74 \\
\hline 7016 & 2813413 & 6315504 & 456.3 & 49504.6 & 60423 & -0.2 & -1.5 & 597.7 & 104.6 & 258.4 & 345.14 & -240.54 \\
\hline 7017 & 2814330 & 6316165 & 438.6 & 49554.7 & 60423 & -0.1 & -1.7 & 598.7 & 125.2 & 275.9 & 346.39 & -221.19 \\
\hline 7018 & 2814691 & 6317170 & 447.6 & 49517.5 & 60423 & -0.1 & -2.3 & 597.3 & 114.7 & 261.3 & 352.85 & -238.15 \\
\hline 7019 & 2815166 & 6318190 & 448.6 & 49515.7 & 60423 & -0.2 & -3.6 & 606.8 & 124.2 & 266.9 & 358.94 & -234.74 \\
\hline 7020 & 2816255 & 6318847 & 464.3 & 49484.6 & 60423 & -0.4 & -5.3 & 629.7 & 131.7 & 270.7 & 359.51 & -227.81 \\
\hline 7021 & 2816193 & 6319785 & 414.9 & 49570.3 & 60423 & -0.1 & -7.3 & 570.3 & 128.5 & 264.5 & 367.27 & -238.77 \\
\hline 7022 & 2813095 & 6314423 & 469 & 49496.5 & 60423 & -0.1 & -1.5 & 620.2 & 113 & 270.6 & 337.91 & -224.91 \\
\hline 7023 & 2812690 & 6313458 & 478.8 & 49495.2 & 60423 & -0.2 & -1.8 & 641.4 & 123.8 & 284.7 & 331.99 & -208.19 \\
\hline 7024 & 2811721 & 6312941 & 467.2 & 49533.8 & 60423 & -0.1 & -1.7 & 639.8 & 134.8 & 298.6 & 332.19 & -197.39 \\
\hline 7025 & 2805981 & 6318795 & 476.3 & 49362.5 & 60424 & -0.8 & -5.3 & 541.1 & 30.2 & 181.1 & 399.20 & -369.00 \\
\hline 7026 & 2806944 & 6319125 & 399.9 & 49548.4 & 60424 & -0.5 & -4.3 & 494.2 & 66.4 & 215.4 & 398.17 & -331.77 \\
\hline
\end{tabular}




\begin{tabular}{|c|c|c|c|c|c|c|c|c|c|c|c|c|}
\hline Station & $x$ & $Y$ & Height & Gravity & Date & $\begin{array}{c}\text { Inner } \\
\text { Terrain }\end{array}$ & $\begin{array}{l}\text { Outer } \\
\text { Terrain }\end{array}$ & FAA & BA & ISA & Regional & Residual \\
\hline 7027 & 2807113 & 6319720 & 395.4 & 49556.5 & 60424 & -0.5 & -6 & 493.1 & 72 & 218.7 & 401.86 & -329.86 \\
\hline 7028 & 2807032 & 6320682 & 444.5 & 49436.1 & 60424 & -0.5 & -3.7 & 531.8 & 53.9 & 197.4 & 409.02 & -355.12 \\
\hline 7029 & 2806565 & 6321152 & 459.8 & 49400.1 & 60424 & -2.1 & -6.7 & 546.5 & 56.2 & 198.7 & 413.93 & -357.73 \\
\hline 7030 & 2807023 & 6321545 & 463.2 & 49390.8 & 60424 & -1 & -7.4 & 551 & 56.5 & 197.2 & 415.18 & -358.68 \\
\hline 7031 & 2807718 & 6321305 & 444 & 49443.3 & 60424 & -1.9 & -4.8 & 542.5 & 67.6 & 208.4 & 411.12 & -343.52 \\
\hline 7032 & 2808150 & 6322029 & 434.6 & 49468.5 & 60424 & -0.7 & -7.1 & 544.6 & 81.1 & 219.1 & 414.82 & -333.72 \\
\hline 7033 & 2809039 & 6322650 & 529.5 & 49259.3 & 60424 & -2.3 & -31.7 & 633.4 & 90.9 & 226.3 & 416.25 & -325.35 \\
\hline 7034 & 2808859 & 6321526 & 358.9 & 49635.9 & 60424 & -1 & -6.4 & 474.7 & 94.7 & 233.5 & 408.77 & -314.07 \\
\hline 7035 & 2809768 & 6321504 & 338.9 & 49693.1 & 60424 & -0.1 & -7.4 & 470.2 & 112.4 & 250.5 & 405.40 & -293.00 \\
\hline 7036 & 2808453 & 6320829 & 383.8 & 49567.9 & 60424 & -1.3 & -10.8 & 477.9 & 75 & 216.8 & 405.14 & -330.14 \\
\hline 7037 & 2808204 & 6320158 & 547.2 & 49215.1 & 60424 & -0.6 & -22.2 & 623.8 & 51.3 & 195 & 401.16 & -349.86 \\
\hline 7038 & 2809426 & 6317020 & 401 & 49590.1 & 60424 & -0.3 & -2.9 & 523.4 & 92.8 & 245.8 & 373.40 & -280.60 \\
\hline 7039 & 2808705 & 6316071 & 421.1 & 49539.3 & 60424 & -0.3 & -1.9 & 526.9 & 73.3 & 230.2 & 369.09 & -295.79 \\
\hline 7040 & 2810894 & 6314551 & 432.9 & 49546.2 & 60424 & -0.5 & -1.6 & 558.8 & 92 & 251.4 & 348.49 & -256.49 \\
\hline 7041 & 2832285 & 6325288 & 429.4 & 49623.1 & 60425 & -0.1 & -5.1 & 716.5 & 254.8 & 346.1 & 338.40 & -83.60 \\
\hline 7042 & 2820769 & 6326598 & 388.6 & 49399.9 & 60425 & -0.9 & -26.4 & 374 & -20.4 & 84.3 & 402.71 & -423.11 \\
\hline 7043 & 2818545 & 6330151 & 330.8 & 49406.3 & 60425 & -0.1 & -11 & 229.4 & -117.2 & -22.3 & 438.76 & -555.96 \\
\hline 7044 & 2818933 & 6329256 & 343.8 & 49389.6 & 60425 & -0.1 & -11.5 & 245.9 & -114.8 & -16.8 & 430.54 & -545.34 \\
\hline 7045 & 2819304 & 6328391 & 348.5 & 49381.4 & 60425 & -0.1 & -18 & 245.4 & -113.9 & -13 & 422.50 & -536.40 \\
\hline 7046 & 2820070 & 6328139 & 293.8 & 49516.5 & 60425 & -0.1 & -22.1 & 210 & -84.5 & 15.5 & 417.64 & -502.14 \\
\hline 7047 & 2820276 & 6327252 & 353.4 & 49430.9 & 60425 & -0.6 & -27 & 301.4 & -53.7 & 49.3 & 409.87 & -463.57 \\
\hline 7048 & 2821165 & 6325631 & 474.2 & 49279.5 & 60425 & -0.1 & -19 & 510.2 & 13.1 & 120.3 & 393.33 & -380.23 \\
\hline 7049 & 2821465 & 6324688 & 508.7 & 49267.4 & 60425 & -0.3 & -20.2 & 597.2 & 63.5 & 173.7 & 384.42 & -320.92 \\
\hline 7050 & 2821966 & 6323902 & 591.6 & 49137.1 & 60425 & -0.4 & -15.2 & 716.7 & 86.4 & 198.2 & 375.81 & -289.41 \\
\hline 7051 & 2822262 & 6323366 & 604.2 & 49139 & 60425 & -0.1 & -13.2 & 753.2 & 106.9 & 220.2 & 370.07 & -263.17 \\
\hline 7052 & 2822062 & 6322512 & 588.7 & 49182.9 & 60425 & -0.3 & -15.4 & 742.6 & 116.3 & 232.8 & 363.86 & -247.56 \\
\hline 7053 & 2827233 & 6332593 & 104.1 & 50166.4 & 60425 & -0.3 & -15.8 & 312 & 221.2 & 291.1 & 425.17 & -203.97 \\
\hline 7054 & 2826394 & 6332122 & 99.7 & 50185.8 & 60425 & 0 & -11.5 & 313.8 & 223.5 & 296.9 & 424.70 & -201.20 \\
\hline 7055 & 2827372 & 6331288 & 108.3 & 50169.8 & 60425 & 0 & -10.9 & 318.1 & 218.2 & 292.8 & 413.80 & -195.60 \\
\hline 7056 & 2828276 & 6329991 & 106.1 & 50235.7 & 60425 & -0.5 & -13 & 367.2 & 272.5 & 351.5 & 399.04 & -126.54 \\
\hline
\end{tabular}




\begin{tabular}{|c|c|c|c|c|c|c|c|c|c|c|c|c|}
\hline Station & $x$ & $Y$ & Height & Gravity & Date & $\begin{array}{c}\text { Inner } \\
\text { Terrain }\end{array}$ & $\begin{array}{c}\text { Outer } \\
\text { Terrain }\end{array}$ & FAA & BA & ISA & Regional & Residual \\
\hline 7057 & 2829341 & 6329960 & 164.9 & 50133.3 & 60425 & -0.7 & -12.2 & 446.4 & 285.6 & 362.5 & 394.03 & -108.43 \\
\hline 7058 & 2829677 & 6327967 & 249.5 & 50009.1 & 60425 & -0.7 & -9 & 567.6 & 309.5 & 394 & 375.26 & -65.76 \\
\hline 7059 & 2830608 & 6326541 & 380.6 & 49748.3 & 60425 & -0.8 & -12.4 & 700.4 & 300.4 & 388.7 & 358.21 & -57.81 \\
\hline 7060 & 2818064 & 6313546 & 444.2 & 49599.5 & 60425 & -0.1 & -2.3 & 641.2 & 162.4 & 317.5 & 307.33 & -144.93 \\
\hline 7061 & 2818123 & 6314538 & 445.4 & 49597.7 & 60425 & 0 & -1.5 & 651 & 169.8 & 321.5 & 315.44 & -145.64 \\
\hline 7062 & 2823442 & 6320836 & 440.7 & 49582.2 & 60426 & 0 & -4.7 & 672.5 & 198.9 & 319.8 & 343.30 & -144.40 \\
\hline 7063 & 2823958 & 6320208 & 467.2 & 49532.6 & 60426 & -0.1 & -3.8 & 699.7 & 196.1 & 318.6 & 335.40 & -139.30 \\
\hline 7064 & 2824307 & 6319487 & 446.4 & 49609.1 & 60426 & -0.1 & -2.9 & 706.6 & 225.1 & 349.9 & 327.42 & -102.32 \\
\hline 7065 & 2824694 & 6318834 & 448.6 & 49621 & 60426 & -0.2 & -3.4 & 720.2 & 237.3 & 363.9 & 319.75 & -82.45 \\
\hline 7066 & 2823958 & 6317834 & 483.6 & 49553.3 & 60426 & -0.1 & -3.7 & 752.3 & 231.1 & 362.8 & 314.71 & -83.61 \\
\hline 7068 & 2826164 & 6317929 & 446.4 & 49625.6 & 60426 & -0.1 & -2.6 & 711.3 & 230.1 & 358.7 & 304.06 & -73.96 \\
\hline 7069 & 2832023 & 6324513 & 441.4 & 49592.7 & 60426 & -0.1 & -8.5 & 716.9 & 245.3 & 340.1 & 332.70 & -87.40 \\
\hline 7070 & 2831477 & 6323282 & 405.3 & 49684.6 & 60426 & -0.1 & -3.2 & 687.5 & 250.5 & 351.5 & 324.33 & -73.83 \\
\hline 7071 & 2830579 & 6321861 & 404.9 & 49678.7 & 60426 & -0.1 & -3.1 & 668.9 & 233.2 & 340.9 & 316.12 & -82.92 \\
\hline 7072 & 2831710 & 6320030 & 384.8 & 49697.7 & 60426 & -0.1 & -4.5 & 611.7 & 199.7 & 311.7 & 292.89 & -93.19 \\
\hline 7073 & 2832372 & 6319333 & 414.2 & 49612.3 & 60426 & 0 & -2.8 & 611.8 & 165.4 & 279.1 & 282.51 & -117.11 \\
\hline 7074 & 2835344 & 6317033 & 347.6 & 49657.3 & 60426 & 0 & -3.2 & 434 & 62.1 & 181.3 & 242.12 & -180.02 \\
\hline 7075 & 2834027 & 6317792 & 372.8 & 49643.3 & 60426 & 0 & -2.8 & 503.4 & 103 & 220.8 & 257.81 & -154.81 \\
\hline 7076 & 2830889 & 6320983 & 410 & 49662.5 & 60426 & -0.1 & -3 & 661.5 & 220.2 & 329.8 & 306.35 & -86.15 \\
\hline 7077 & 2820709 & 6318268 & 453.8 & 49561.4 & 60426 & 0 & -2.9 & 670.9 & 181.7 & 317 & 334.50 & -152.80 \\
\hline 7078 & 2819453 & 6312239 & 436.6 & 49630.5 & 60426 & -0.1 & -2.8 & 638.9 & 169.1 & 326.8 & 289.03 & -119.93 \\
\hline 7079 & 2812893 & 6310560 & 515.2 & 49418.4 & 60426 & -0.1 & -1.4 & 654 & 96.6 & 265.8 & 307.53 & -210.93 \\
\hline 7080 & 2804150 & 6323920 & 563.8 & 49062.5 & 60427 & -0.1 & -8.4 & 551 & -54.8 & 81.6 & 440.59 & -495.39 \\
\hline 7081 & 2804773 & 6323811 & 537.1 & 49144.5 & 60427 & -0.1 & -7.1 & 549.9 & -27.8 & 108.4 & 438.00 & -465.80 \\
\hline 7082 & 2805587 & 6323910 & 491.4 & 49259.6 & 60427 & 0 & -7.2 & 525 & -2.3 & 132.8 & 436.22 & -438.52 \\
\hline 7083 & 2806351 & 6324429 & 480.9 & 49299.2 & 60427 & 0 & -6.2 & 536.5 & 19.7 & 152.2 & 437.44 & -417.74 \\
\hline 7084 & 2806910 & 6324941 & 426 & 49430.4 & 60427 & 0 & -6.8 & 502.6 & 47 & 177.5 & 439.25 & -392.25 \\
\hline 7085 & 2807415 & 6325645 & 449.6 & 49366.9 & 60427 & -0.1 & -14.5 & 517.6 & 43.7 & 171.1 & 442.56 & -398.86 \\
\hline 7086 & 2807519 & 6324578 & 452.2 & 49399.5 & 60427 & -0.1 & -7.5 & 549.8 & 66 & 196.7 & 434.85 & -368.85 \\
\hline 7087 & 2804471 & 6324851 & 565.5 & 49133.1 & 60427 & 0 & -14.1 & 634.2 & 32.2 & 165.5 & 445.89 & -413.69 \\
\hline
\end{tabular}




\begin{tabular}{|c|c|c|c|c|c|c|c|c|c|c|c|c|}
\hline Station & $x$ & Y & Height & Gravity & Date & $\begin{array}{c}\text { Inner } \\
\text { Terrain }\end{array}$ & $\begin{array}{c}\text { Outer } \\
\text { Terrain }\end{array}$ & FAA & BA & ISA & Regional & Residual \\
\hline 7088 & 2804927 & 6325503 & 563.1 & 49043.2 & 60427 & -0.1 & -14.7 & 542.2 & -56.4 & 74.2 & 448.94 & -505.34 \\
\hline 7089 & 2805339 & 6326059 & 512.6 & 49158.9 & 60427 & 0 & -11.4 & 506.6 & -39.9 & 88.5 & 451.48 & -491.38 \\
\hline 7090 & 2805741 & 6326841 & 468.8 & 49247.7 & 60427 & -0.1 & -27.4 & 466.6 & -16.1 & 109.8 & 455.58 & -471.68 \\
\hline 7091 & 2803002 & 6323952 & 567.7 & 49131.1 & 60427 & -0.2 & -11.1 & 631.5 & 24.2 & 162 & 444.14 & -419.94 \\
\hline 7092 & 2802259 & 6323840 & 568.6 & 49034.6 & 60427 & -0.1 & -6.7 & 536.7 & -76.3 & 62.7 & 445.51 & -521.81 \\
\hline 7093 & 2801701 & 6324546 & 539.2 & 49109.7 & 60427 & -0.2 & -5.9 & 526.5 & -55.1 & 83.2 & 451.67 & -506.77 \\
\hline 7094 & 2801555 & 6326005 & 484.8 & 49199.6 & 60427 & -0.1 & -11.4 & 460.1 & -56 & 76.5 & 461.45 & -517.45 \\
\hline 7095 & 2801805 & 6325413 & 516.8 & 49148.1 & 60427 & -0.3 & -9.7 & 502.7 & -50.3 & 85.2 & 456.99 & -507.29 \\
\hline 7096 & 2803649 & 6324403 & 459.4 & 49247.7 & 60427 & -0.6 & -15.5 & 417.7 & -65.5 & 70.6 & 445.27 & -510.77 \\
\hline 7097 & 2803871 & 6325308 & 419.4 & 49302.1 & 60427 & -1.2 & -20.6 & 355.9 & -77.5 & 55.6 & 450.64 & -528.14 \\
\hline 7098 & 2803678 & 6326094 & 395.8 & 49359.2 & 60427 & -0.5 & -27.6 & 346.3 & -54.7 & 76 & 456.36 & -511.06 \\
\hline 7099 & 2803664 & 6326943 & 385.5 & 49373.3 & 60427 & -0.1 & -20.7 & 335.3 & -62.1 & 66.2 & 461.95 & -524.05 \\
\hline 7100 & 2807230 & 6331421 & 317.2 & 49664.6 & 60427 & -0.2 & -12 & 452.3 & 121.6 & 230.7 & 481.94 & -360.34 \\
\hline 7101 & 2807015 & 6329754 & 318.8 & 49617.4 & 60427 & -0.4 & -13.8 & 396.8 & 66.5 & 182.1 & 471.49 & -404.99 \\
\hline 7102 & 2804845 & 6327209 & 392.7 & 49386.4 & 60427 & -0.3 & -16.7 & 373.2 & -36 & 90 & 460.50 & -496.50 \\
\hline 7103 & 2824260 & 6319887 & 467 & 49544.2 & 61216 & -0.3 & -3.3 & 708.3 & 204.6 & 327.9 & 331.13 & -126.53 \\
\hline 7104 & 2825521 & 6320844 & 475.2 & 49549.3 & 61216 & -0.1 & -6.9 & 746.7 & 237.3 & 354.9 & 333.21 & -95.91 \\
\hline 7105 & 2826741 & 6322154 & 426.6 & 49642.9 & 61216 & -0.3 & -10.8 & 701 & 249.4 & 361.1 & 338.62 & -89.22 \\
\hline 7106 & 2827901 & 6323521 & 405 & 49674 & 61216 & -0.1 & -9.6 & 676.7 & 246.9 & 351.6 & 344.89 & -97.99 \\
\hline 7107 & 2827988 & 6325210 & 343.6 & 49812 & 61216 & -0.2 & -8 & 638.6 & 275.2 & 373.1 & 359.27 & -84.07 \\
\hline 7108 & 2828669 & 6327370 & 239.8 & 50023.7 & 61216 & -0.1 & -9.8 & 547.2 & 300.1 & 389 & 374.81 & -74.71 \\
\hline 7109 & 2828323 & 6329097 & 139.5 & 50164.8 & 61216 & -0.3 & -9.4 & 392.4 & 256.6 & 339.4 & 391.23 & -134.63 \\
\hline
\end{tabular}


Table 6.2: Independent constraints on depth to basement with corresponding residual gravity anomalies. Estimated errors for depths to basement; drill-hole depths $\pm 50 \mathrm{~m}$; seismic refraction $\pm 10 \%$, seismic reflection $\pm 15 \%$, seismic tomography and magnetotelluric models $\pm 500 \mathrm{~m}$.

\begin{tabular}{|c|c|c|c|c|c|}
\hline Data Type & Name & $\begin{array}{l}\text { Depth } \\
\text { (m) }\end{array}$ & $\begin{array}{c}\Delta \mathrm{g} \\
(\mathrm{mGal})\end{array}$ & Source & Composition \\
\hline Drill-hole & Otakiri-3 & 400 & -11.84 & Woodward [1988) & Greywacke \\
\hline Drill-hole & Kawerau-23 & 970 & -23.54 & GNS PETLAB & Greywacke \\
\hline Drill-hole & Kawerau-21 & 1028 & -23.35 & GNS PETLAB & Greywacke \\
\hline $\begin{array}{l}\text { Seismic } \\
\text { Refraction }\end{array}$ & Tarawera Forest & 350 & -10.34 & Rogan [1980] & $\begin{array}{l}\text { Greywacke } \\
\text { (inferred) }\end{array}$ \\
\hline $\begin{array}{l}\text { Seismic } \\
\text { Refraction }\end{array}$ & Kaingaroa Plateau & 650 & -14.00 & Stagpoole [1994] & $\begin{array}{l}\text { Greywacke } \\
\text { (inferred) }\end{array}$ \\
\hline $\begin{array}{l}\text { Seismic } \\
\text { Refraction }\end{array}$ & Rotoehu & 1800 & -30.80 & Stern [1986] & Unknown \\
\hline $\begin{array}{c}\text { Seismic } \\
\text { Refraction }\end{array}$ & Stern [unpubl.] & 1600 & -33.81 & Woodward [1988] & $\begin{array}{l}\text { Greywacke } \\
\text { (inferred) }\end{array}$ \\
\hline $\begin{array}{l}\text { Seismic } \\
\text { Refraction }\end{array}$ & Mangakino & 2000 & -37.90 & Stern [1986] & Unknown \\
\hline $\begin{array}{l}\text { Seismic } \\
\text { Refraction }\end{array}$ & Wairakei & 2200 & -36.80 & Stern [1986] & Andesite \\
\hline $\begin{array}{l}\text { Seismic } \\
\text { Reflection }\end{array}$ & Line 6 & 470 & -11.03 & Woodward [1988] & $\begin{array}{l}\text { Greywacke } \\
\text { (inferred) }\end{array}$ \\
\hline $\begin{array}{l}\text { Seismic } \\
\text { Reflection }\end{array}$ & Rangitaiki Plains & 730 & -14.70 & $\begin{array}{l}\text { Mouslopoulou et al. } \\
\text { [2008] }\end{array}$ & $\begin{array}{l}\text { Greywacke } \\
\text { (inferred) }\end{array}$ \\
\hline $\begin{array}{c}\text { Seismic } \\
\text { Tomography }\end{array}$ & Haroharo Caldera & $>4000$ & -52.60 & $\begin{array}{c}\text { Sherburn et al. } \\
\text { [2003] }\end{array}$ & Unknown \\
\hline $\begin{array}{l}\text { Preliminary } \\
\text { MT model }\end{array}$ & Haroharo Caldera & 3000 & -52.60 & $\begin{array}{l}\text { Bibby [unpublished } \\
\text { data, 2007] }\end{array}$ & $\begin{array}{l}\text { Greywacke } \\
\text { (inferred) }\end{array}$ \\
\hline
\end{tabular}


Table 6.3: PETLAB TVZ geothermal drill-hole summary. Header; Drill-hole name, collection date, collector, and NZMG location for all sub-surface composition and density rock data extracted from the GNS Science PETLAB Database.

\begin{tabular}{|c|c|c|c|c|}
\hline Feature_Name & Collection_Date & Collectors & NZMG_East & NZMG_North \\
\hline Broadlands-1 & 01-Jan-66 & Ministry Of Works & 2799460 & 6292720 \\
\hline Broadlands-10 & 01-Jan-68 & Ministry Of Works & 2799650 & 6291300 \\
\hline Broadlands-16 & 01-Jan-69 & Ministry Of Works & 2800133 & 6290777 \\
\hline Broadlands-2 & 01-Jan-67 & Ministry Of Works & 2798000 & 6292700 \\
\hline Broadlands-14 & 01-Jan-69 & Ministry Of Works & 2799320 & 6291890 \\
\hline Broadlands-20 & 01-May-70 & NZ Geological Survey & 2798680 & 6292660 \\
\hline Broadlands-25 & 01-Dec-82 & Hunt, T. & 2798810 & 6291430 \\
\hline Broadlands-26 & 01-Jul-78 & NZ Geological Survey & 2799000 & 6292500 \\
\hline Broadlands-43 & 26-Jul-85 & Allis, R.G. & 2799110 & 6291690 \\
\hline Broadlands-7 & 01-Jan-68 & & 2799600 & 6290780 \\
\hline Broadlands-28 & 01-Aug-74 & NZ Geological Survey & 2798765 & 6290907 \\
\hline Broadlands-3 & 01-Jan-67 & Ministry Of Works & 2798630 & 6293350 \\
\hline Kawerau-10 & 01-Jan-70 & Ministry Of Works & 2836422 & 6341785 \\
\hline Kawerau-14 & 01-Jan-70 & Ministry Of Works & 2836510 & 6341691 \\
\hline Kawerau-21 & 01-May-75 & NZ Geological Survey & 2837249 & 6341945 \\
\hline Kawerau-23 & 01-Aug-75 & NZ Geological Survey & 2831461 & 6341012 \\
\hline Kawerau-16 & 01-Jan-70 & Ministry Of Works & 2836166 & 6342433 \\
\hline Kawerau-8 & 01-Jan-70 & Ministry Of Works & 2835787 & 6341986 \\
\hline Kawerau-3 & 01-Jan-70 & Ministry Of Works & 2836249 & 6342156 \\
\hline Mangakino-1 & 11-Feb-86 & Mumme, T.C. & 2754500 & 6312300 \\
\hline Mokai-2 & 16-Dec-86 & NZ Geological Survey & 2765600 & 6294600 \\
\hline Mokai-6 & 16-Dec-86 & NZ Geological Survey & 2765700 & 6292700 \\
\hline Ngatamariki-2 & 01-Dec-88 & NZ Geological Survey & 2787700 & 6291400 \\
\hline Ngatamariki-4 & 13-Dec-85 & Allis, R.G. & 2787300 & 6292600 \\
\hline Ngatamariki-3 & 13-Dec-85 & Allis, R.G. & 2787100 & 6290500 \\
\hline Orakeikorako-1 & 01-Jan-66 & & 2785726 & 6298775 \\
\hline Rotokawa-4 & 23-Jul-84 & Mumme, T.C. & 2788800 & 6282200 \\
\hline Rotokawa-6 & 26-Jul-85 & Allis, R.G. & 2788200 & 6284500 \\
\hline Rotokawa-8 & 07-Jul-88 & Mumme, T.C. & 2787500 & 6285400 \\
\hline Tauhara-1 & 01-Jan-66 & & 2780701 & 6276328 \\
\hline Tauhara-4 & 01-Jan-67 & & 2780176 & 6277166 \\
\hline Te Kopia-1 & 01-Jan-66 & & 2790028 & 6305330 \\
\hline Waiotapu-7 & 15-Aug-88 & NZ Geological Survey & 2804300 & 6310100 \\
\hline Wairakei-121 & 01-Jan-71 & NZ Geological Survey & 2777024 & 6282102 \\
\hline Wairakei-205 & 01-Jan-84 & Raynor, H.H. & 2776249 & 6280570 \\
\hline Wairakei-212 & 01-Jan-66 & & 2775473 & 6282238 \\
\hline Wairakei-224 & 01-Jan-84 & Raynor, H.H. & 2773196 & 6282577 \\
\hline Wairakei-207 & 01-Jan-84 & Raynor, H.H. & 2776217 & 6282674 \\
\hline Wairakei-48 & 01-Jan-59 & Studt, F.E. & 2777671 & 6282358 \\
\hline
\end{tabular}




\section{APPENDIX II: Topographic analysis}

This appendix contains information on the digital elevation model used for the measurement of fault displacements.

\subsection{Aerial Photographs}

Orthorectified aerial photographs allow the detailed mapping of active fault traces along with identification of suitable locations for the measurement of vertical displacements from a Digital Elevation Model (DEM). The aerial photograph dataset consisted of scanned 1:17 000 black and white photographs (DSIR 1949/50) and 1:2 000 digital colour (EBOP 2002) images. Environment Bay of Plenty (EBOP) provided high resolution orthorectified digital aerial photographs of the Okataina Volcanic Centre with a horizontal resolution of $\pm 5 \mathrm{~m}$. Scanned black and white DSIR aerial photographs were orthorectified against the EBOP images using control points common in both sets of data. The addition of the DSIR data set has the benefit of a reduced vegetation cover at the time of creation and optimum light conditions for the identification of normal fault scraps.

The EBOP aerial photographs and TOPSAR digital elevation models (DEM) were created at approximately the same time (2002 and 2000 respectively). The TOPSAR DEM product creates an image of the Earth's surface and therefore typically reflects surface features observed in the EBOP aerial photographs (e.g. trees, houses, forest boundaries etc.) with the exception of some of the commercial forests which undergo periodic clearance.

\subsection{TOPSAR DEM}

The TOPSAR digital elevation models are generated by synthetic aperture radar with 5 m grid spacing. The TOPSAR DEM tiles (ts1292 and ts1293) were flown in August 2000 with each tile covering an area of $60 \times 12 \mathrm{~km}$ orientated $035^{\circ}$ (i.e. parallel to the Taupo Rift). Both tiles encompass the study area. Landcare Research processed the raw data to a raster format compatible with Leica ERDAS Imagine software. Altitude offsets, referenced to the ellipsoid, were corrected via the scaling factor associated with the peg point for the flight line while EBOP digital aerial photographs were used to orthorectify the image using control points common to both data sets. The horizontal orthorectification accuracy of the DEM images is $\pm 10 \mathrm{~m}$ (rms). 


\subsubsection{TOPSAR background}

Interferometric principles can be used to obtain topographic elevation information through the coherent addition of the receiver signals from two spatially separated synthetic aperture radar (SAR) antennas [Zebker \& Goldstein, 1986]. These two interferometric channels are individually processed into complex images, and when combined together, produce a complex interferogram containing phase information directly related to surface topography [Zebker \& Goldstein, 1986; Madsen et al., 1995].

Imaging radar illuminates a topographic surface with particular microwave wavelengths (in the range $1 \mathrm{~cm}$ to $1 \mathrm{~m}$ or $\sim 300 \mathrm{MHz}$ to $30 \mathrm{GHz}$ ) and polarizations (waves polarized in a single vertical or horizontal plane) [Freeman, 1996]. The radar antenna alternately transmits and receives microwave pulses reflected off a distant surface or object, measuring the strength and two-way travel time of the reflected arrivals. Each pulse ranges over a small band of frequencies centred on a selected radar frequency with bandwidths typically ranging from 10 to $200 \mathrm{MHz}$ [Freeman, 1996].

The energy of the radar pulse is scattered in all directions by the topographic surface with a small proportion reflected back toward the antenna in a specific polarization (horizontal or vertical, and not necessarily the same as the transmitted pulse). The measured two-way travel time of a particular pulse, travelling at the speed of light, is used to calculate the distance or range to a reflecting object, with the chosen bandwidth determining the resolution in the range (cross-track direction) [Freeman, 1996].

The resolution in the azimuth (along-track) direction of the image is determined by the length of the radar antenna: longer antennas produce finer resolution in this dimension. The Synthetic Aperture Radar (SAR) is a mature technique that synthesizes a very long antenna through the combination of signals through a series of positions along a flight track [Freeman, 1996].

\subsubsection{TOPSAR radar system}

NASA/JPL currently maintain an airborne SAR system known as AIRSAR/TOPSAR which simultaneously collects all four polarizations (HH, HV, VH, VV) for two frequencies: L-band $(\lambda \sim 24 \mathrm{~cm})$; and P-band $(\lambda \sim 68 \mathrm{~cm})$, and operating as an interferometer at C-band $(\lambda \sim 6 \mathrm{~cm})$ to simultaneously generate topographic height data [Madsen et al. 1995].

The two antennas of the TOPSAR system are mounted at the same along-track position (with a separation (baseline) in the cross-track plane of $2.5 \mathrm{~m}$ ) on the left side of 
a DC-8 with the bore sights of the antennas depressed $45^{\circ}$ with respect to horizontal. One antenna is used for transmission while both antennas independently record the returning signal [Madsen et al. 1995]. The TOPSAR single-pass implementation provides a significant advantage over repeat single antenna methods by avoiding problems associated with temporal decorrelation of the topographic surface. For example, changes on the wavelength of the surface created by precipitation can introduce additional decorrelation noise to the inferogram [Zebker et al. 1992].

The horizontal and vertical position of the aircraft during a flight-line are measured through three independent navigations systems: the Digital Avionics Data system (DADS) (including the aircraft inertial navigation system, barometric altimeter, and a radar altimeter), a Global Positioning System (GPS), and a radar inertial navigation system (LASEREF). The DADS and GPS data are relatively accurate (GPS accuracy is typically $25-75 \mathrm{~m}$ ), but are only sampled at a $1 \mathrm{~Hz}$ rate. This is in contrast to the LASEREF which provides accelerations and attitudes at a $50 \mathrm{~Hz}$ rate. The LASEREF system however is not locked to either of the other systems and biases in position, elevation and velocities tend to increase with time. A high update rate and low drift with time is achieved through the combination of the different data sets [Madsen et al., 1995].

\subsubsection{Synthetic Aperture Radar (SAR) theory}

Zebker et al. [1992] outline the basic principles behind the calculation of topographic elevation from SAR data. Fig. 7.1 shows a set of two antennas A1 and A2 and where the surface topography is given by $z(y), h$ is the aircraft altitude, the baseline distance is $B$, the range to a point on the ground is $\rho$, the look angle $\theta$, and the angle of the baseline with respect to horizontal is $\alpha$.

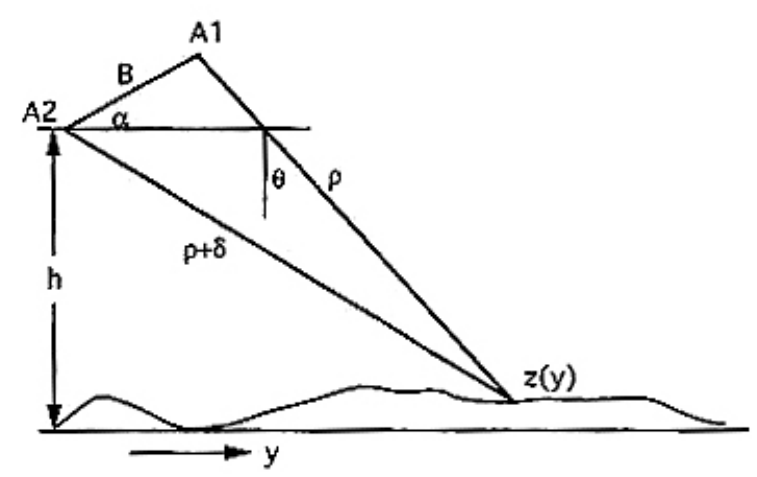

Fig. 7.1. Synthetic Aperture Radar theory for the calculation of topographic surfaces from Zebker et al. [1992] 
Microwave pulses are transmitted from antenna A1 and received simultaneously by A1 and A2. The difference in path length is $\delta$ and is dependent on the baseline distance, baseline angle, range, look angle, and on the height of the point $\mathrm{z}(\mathrm{y})$. The measured phase $(\varphi)$ of the inferometer is directly proportional $(2 \pi / \lambda)$ to this distance, Height as a function of these parameters can then be expressed:

$$
\begin{aligned}
& \delta=\lambda \varphi / 2 \pi \\
& \sin (\alpha-\theta)=-\left((\rho+\delta)^{2}-\rho^{2}-\mathrm{B}^{2}\right) /(2 \rho \mathrm{B}) \\
& \mathrm{z}(\mathrm{y})=\mathrm{h}-\rho \cos \alpha \cos (\alpha-\theta)-\rho \sin \alpha \sin (\alpha-\theta)
\end{aligned}
$$

where is the $\lambda$ is the wavelength. By measuring the phase at each point in an image, and applying equations based on imaging geometry, the topographic height at each point can be calculated [Zebker et al. 1992].

\subsubsection{Sources of Error}

One fundamental source of error for the TOPSAR product is the random error created by phase noise. Both thermal noise and decorrleation of the signals caused by the slightly different observation geometries of the two antennas will cause phase noise. Systematic errors are introduced during the conversion of the phase measurements to geometric coordinates by errors in conversion parameters. Systematic errors such as height offset, horizontal scale error and vertical tilt can be removed to a first order by the application of topographic control points [Madsen et al. 1995].

Topographic elevation data acquired by the TOPSAR interferometric SAR system has an accuracy (rms) of vertical error measured at $\pm 1 \mathrm{~m}$ in flat areas, $\pm 5 \mathrm{~m}$ in mountainous areas, and $\pm 2 \mathrm{~m}$ overall for an accurately orthorectified image [Madsen et al. 1995]. The comparison between DEM and field displacement measurements undertaken for this study has standard error $(1 \sigma)$ of $\pm 1.31 \mathrm{~m}$ (Fig. 3.2). This shows that the TOPSAR DEM accurately reflects relative topographic height differences across the study area.

\subsection{Vertical fault displacement analysis}

Leica ERDAS Imagine software was used to analysis the DEM ts1292 and ts1293 for the Whirinaki and Paeroa Fault zones respectively. This software allows the control and topographic profiling of the DEM, the addition of fault maps created from aerial 
photograph analysis, and the positioning of an artificial light source for the optimal illumination of fault scarps (e.g. Fig. 3.2).

Topographic profiles created normal to the trend of the each individual fault trace, in combination with aerial photographs, provide a method for assessing the most suitable location for vertical displacement measurement. Surface horizons, where required, have been projected across the high points between fault scarps in areas of undulating topography. Stream erosion parallel and perpendicular to the regional fault trend is pervasive in the study area and care must be taken to estimate the original surface horizon. From initial fault displacement locations identified through analysis of aerial photographs, surfaces are reviewed for slope changes, stream incision, and consistency of fault displacement either side of a chosen location using a topographic profiling tool.

The altitude of the foot wall and hanging wall surfaces projected to an approximated fault plane are identified. The difference in the altitude between the offset surfaces is measured as the vertical displacement on the fault at a given location. This process is repeated along the fault trace in suitable locations, for example, in areas without vegetation, extensive erosion and/or land surface modification. The location of each vertical displacement measurement was then collated into a GIS database file to facilitate direct comparison to mapped geology, which enables the age of the faulted surface to be estimated [Nairn, 1986, 2002]. 